\title{
SAVIVALDYBIŲ VIEŠŲJŲ BIBLIOTEKŲ MOKSLO TIRIAMOJI VEIKLA 2010-2015 METAIS
}

\author{
Elvyda SKUODYTÉ
}

\section{Santrauka}

Tiriamoji veikla, ivvairios jos formos, o ypač moksliniai tyrimai ir inovacijos - viena iš svarbiu Europos Sajungos politikos strategiju, kuriomis kiekvienoje veiklos srityje siekiama igyti patikimus instrumentus, sudarančius galimybę veikti joje atsakingai, užtikrinti, kad novatoriškos idejjos virstu paklausiais produktais ir (ar) paslaugomis, gerinančiomis žmoniu gyvenima, padedančiomis spręsti ir skubias, ir ilgalaikes visuomenès ar konkrečios bendruomenes problemas.

Savivaldybiu viešnju biblioteku (SVB) mokslo tiriamoji veikla niekuomet nebuvo specialaus tyrimo objektas, tačiau šias bibliotekas taip pat veikia sunkiai prognozuojama vidinès ir išorinès aplinkos kaita, dažnai tvirtinama, jogju tikslams stinga aiškumo, o veiklos rezultatai sunkiai išmatuojami. Manoma, jog šiame sektoriuje rečiau nei kitose biblioteku sistemose tiriamos veiklos pletros tendencijos, planai, vadybiniai sprendimai grindžiami mokslo duomenimis, menkai kontroliuojamas ju igyvendinimas, matuojama įvairiu veiksniu ìtaka, vertinami pasiekti rezultatai. Mokslo tiriamosios veiklos metodais gaunama informacija nelaikoma sprendimu priemimo ištekliumi, nèra praktines patirties rengiant prognozes ir panaudojant tam socialinio modeliavimo metodus. 
Šio tyrimo tikslas - išsiaiškinti, kokia yra mokslo tiriamosios veiklos bükle SVB sektoriuje, suprasti, ar ir kiek jame yra intelektinio įdirbio kuriant naujas žinias ir (ar) taikant jas praktineje biblioteku veikloje.

Tyrimo rezultatai leidžia pastebeti, kad sektoriuje nera patikimu susitarimu nei dèl šios veiklos terminijos, nei dèl turinio, nei dèl procedūru. Nors sektoriaus veiklos laukas tyrinejjamas gana intensyviai, SVB indèlis ị tiriamaja. veikla sektoriuje kuklus, veiklos institucionalizavimo lygis žemas. Didesne savarankiškai atliktu tiriamojo pobüdžio darbu dalis sektoriuje nedokumentuojama, o dokumentuoti darbai retai atitinka tam keliamus reikalavimus; mokslo tiriamosios veiklos instrumentai nepanaudojami realioms biblioteku. veiklos problemoms nustatyti, parengti pasiülymai irgi neatitinka realiu. biblioteku poreikiu, taigi ir vadybiniai ar technologiniai sprendimai, priimti ju pagrindu, tampa nepatikimi.

Tyrimo rezultatai įtikinamai parodo, kad ir moksliniu tyrimu, ir informacines analitines veiklos kompetencijos sektoriuje yra nepakankamos. Struktürinis biblioteku kapitalas arba nevaldomas, arba tai daroma neefektyviai. Nustatyta neatitiktis tarp veiklos dokumentuose reglamentuojamu nuostatu ir realiai atliekamu darbu, smarkiai skiriasi sektoriuje rengiamu informaciniu analitiniu darbu (metu veiklos ataskaitu) autoriu, ju vadovu ir išores ekspertu vertinimai.

Deklaruodami mokslo tiriamosios veiklos teorine reikšmę, jos svarba bibliotekoms ir ju isitvirtinimui socialinèse struktūrose, dauguma SVB vadovu ir SVB darbuotoju nemato sektoriaus biblioteku kaip šios veiklos organizatoriu ir savarankisku vykdytojų. Jie renkasi veiklos modeli, kai šios srities intelektiniai sprendimai ir igyvendinimo praktika telkiami stambesnese korporatyvinèse struktūrose, pirmenybę teikdami Lietuvos nacionalinei Martyno Mažvydo bibliotekai (LNB), iš dalies - apskričiu viešosioms bibliotekoms (AVB). Aukštosios mokyklos nelaikomos pagrindinemis šios veiklos partneremis. 


\section{TYRIMO PAGRINDIMAS IR METODIKA}

\subsection{Tyrimo pagrindimas}

Bibliotekiniu procesu informatizavimas, stiprëjantis biblioteku veiklos intelektinis dèmuo, auganti konkurencija informacinių ir kultūros paslaugų srityje, pavojus išnykti, pasimesti šių paslaugų rinkoje skatina bibliotekas laiku ir tinkamai reaguoti į permainas, ịtaigiai ir teisingai informuoti visuomenę apie savo galimybes dalyvauti paslaugų rinkoje ne tik teikiant kokybiškas paslaugas, bet ir išsaugant institucinį identitetą. İvairiapusès analizès ir vertinimų taip pat reikalauja ir būtinybè bibliotekose dirbančiam darbuotojui suvokti save kaip profesinès veiklos subjektą. Negalime kalbèti apie bibliotekų darbuotojų profesinę savimonę, kol neturèsime pakankamai žinių apie bibliotekas ir bibliotekininkus. Moksliniai ir rinkos tyrimai, informacinè analitinè veikla yra vieni iš patikimiausiu būdų gauti reikalingų žinių apie pokyčius, instrumentai, sudarantys galimybę išsiaiškinti realią būklę viešųjų bibliotekų (VB) sektoriuje. Jie turètų būti itin kruopščiai vertinami ir naudojami.

Atliekant tiriamąją veiklą nustatomi organizacijoje ir jos išorinejje aplinkoje vykstantys pokyčiai, visuomenès ir (ar) jos dalies - aptarnaujamos bendruomenès poreikių plètros tendencijos, užtikrinamas nuolatinis atgalinis bibliotekos, visuomenès ir bendruomenès ryšys. Šiais argumentais paprastai grindžiamas kultūros tyrimų aktualumas ir praktinè nauda.

Tyrimų poreikis tampa ypač aktualus ir dèl XX amžiaus pabaigos socialinių, ekonominių ir politinių, taip pat esminių visuomenės struktūru pokyčių. Bibliotekų skaitytojų (vartotojų) sritis, ilgą laiką buvusi beveik nepaveikta permainu, šiuo metu yra sparčiai kintantis bibliotekos veiklos objektas: formuojasi sudètinga, daugialypė bibliotekos vartotojų struktūra, didēja diferenciacija ir pagal skaitytojų aktyvumą, ir pagal naujus kriterijus (užsièmimo sriti, gyvenimo stilių, pajamas, santykị su informacijos šaltiniais ir kt.), kinta šios grupès mentalitetas. Vienas svarbiausių tiriamosios 
veiklos uždavinių yra patikimai išskirti naujus diferencijuojančius rodiklius, nustatyti jų poveikị vartotojo elgesiui, atskleisti ryšį tarp skaitytojo charakteristikų ir jo socialinių požymių.

Nuolat kintant žmonių poreikiams, aktuali ir patikima informacija apie juos gyvybiškai reikalinga bet kuriai paslaugas teikiančiai organizacijai. Ieškant sprendimų bibliotekose, būtina remtis vartotojų, taip pat ir tų žmonių, kurie jose nesilanko, poreikių analize. Tik gerai žinodamos šiuos poreikius, naudodamos patikimus diagnostikos metodus, bibliotekos turès pagrindą spręsti, kaip joms organizuoti savo informacijos išteklių komplektavimo politiką, naudoti informacinio aptarnavimo formas ir metodus.

Reikalinga strategine informacija ir apie besikeičianti socialinị bibliotekos veiklos kontekstą. Kultūros tyrinètojai jau ketvirtą dešimtmetị analizuoja ir aprašo kintantị kultūros modelị [10], kuris formuojasi radikaliai kintant rinkoms ir sparčiai atsinaujinant technologijoms. Šiandien daugybei žmonių prieinama interaktyviose aplinkose pateikta tekstinè, garso, vaizdo ir duomenu bazių informacija. JAV medijų tyrinètojas H. Jenkinsas, apibūdindamas šị kultūros raidos etapą kaip dalyvanjamaja kultūrą, teigia, kad šiame etape kultūra beveik nekuria kliūčiu meninei kūrybai ir pilietiniam įsitraukimui. Dar daugiau - ji itin skatina ir kūrybą, ir dalijimąsi kūriniais ir yra pagrịsta tam tikra neoficialia edukacija, kurią pasitelkę patyrę dalyviai perduoda žinias naujokams [žr. 10, p. 91]. Tokioje aplinkoje kultūros organizacijos veikia kraštutinio neužtikrintumo sąlygomis, taigi jos susiduria ir su poreikiu kitaip organizuoti veiklą. Negebèjimas pažinti arba atsisakymas pripažinti šiuos pokyčius gali reikšti tik tai, kad organizacija vis mažiau galès pasiūlyti paslaugu potencialioms auditorijoms, nusiteikusioms aktyviai dalyvauti kūrybiniuose procesuose.

Šioje situacijoje susiduriama ir su kitais iššukiais. Prieš skirdamos nemažai išteklių vienai ar kitai inovacinei veiklos sričiai, investuodamos i naujas paslaugas ar ịrangą, bibliotekos ne tik turi išlaikyti pusiausvyrą tarp tradicinių jos paslaugų ir investicijų, bet ir atskirti, kas iš tiesų yra tik praeinanti mada, o kas ilgalaikis ir socialiai reikšmingas pokytis. Naujovių 
diegimo praktika tampa ypač svarbi keičiantis bibliotekų veiklos aplinkybẻms - šios įstaigos privalo teikti aukštos kokybès paslaugas su mažèjančiais ištekliais ir operaciniais gebëjimais. Kadangi inovacijoms reikalingu žinių gavimas tiesiogiai siejamas su moksliniais tyrimais ir pletra, svarbu turèti patikimų žinių, ar mokslinè veikla yra viešųjų bibliotekų veiklų sąrašuose, kaip ji suprantama ir koks jos vaidmuo viešųjų bibliotekų veiklų struktūroje. Tik turèdami tokių žinių galèsime modeliuoti bendrąją viešųjų bibliotekų veiklos praktiką nacionalinès mokslinès veiklos sistemos kontekste.

Taigi tyrimai bibliotekose būtini. Be abejo, ir sociologiniai tyrimai, ir rinkodaros metodai viešosiose bibliotekose nèra visiškai nauja praktika. Tačiau nedidelèse bibliotekose, kokios dažniausiai ir yra SVB, aptarnaudami vartotojus bibliotekininkai dažniausiai remiasi savo patirtimi, nors dažnai tokios žinios paviršutiniškos ir niekuo nepagrịstos. Užuot kūrusios ir diegusios inovatyvius produktus ir paslaugas, bibliotekos dažniau vejasi tikrovę, tiria pokyčius, kai jie jau tampa stabiliu, besikartojančiu reiškiniu. Kita vertus, be atodairos, nesirinkdamos diegia naujoves, nors šios pirmiau turètų būti „patikrintos“, „paragautos“ mokslo ir jo aprobuotos. Reikalingi išsamūs tyrinëjimai, nes mitai apie bibliotekas (taip pat ir apie vis mažèjantị bibliotekų lankyma) plinta, nors iš kai kuriose užsienio šalyse atliktų darbų galima spręsti priešingai: bibliotekos atlieka didžiulį vaidmenị visuomenès gyvenime ir jis turi ir gali būti stiprinamas. Akivaizdu, jog bibliotekoms būtina tapti „matomesniu“ socialiniu institutu. Modernizuotos ir tinkamai finansuojamos šios įstaigos visiškai grąžina „ịdètas“ investicijas. Labai svarbu išgvildenti ir daugybę kitu problemu - kad ir paslëptas masinès sąmonès struktūras: vertybines nuostatas, motyvacijas, susiformavusius stereotipus ir t. t. Tik šios žinios leis nustatyti biblioteku veiklos pokyčiams svarbius reiškinius ir jų priežastis, neapsiribojant vien vartotoju „pasitenkinimo“ ar "nepasitenkinimo“ vertinimais.

SVB mokslo tiriamoji veikla Lietuvoje niekuomet nebuvo specialaus tyrimo objektas. O ji tampa gana sudètinga problema dèl daugybès neapibrěžtumų ir vieno požiūrio ị šią veiklą profesinèje bendruomenëje 
stokos. Mokslinès veiklos instrumentai (analizè, vertinimas, palyginimas, apibendrinimas ir t. t.) naudojami daugelyje bibliotekų veiklos sričių: vadyboje - pagrindžiant organizacinius sprendimus, rengiant atskiras veiklos sritis reglamentuojančius dokumentus; gamybinëje veikloje - randant naujus pažangius veiklos metodus ir pritaikant juos bibliotekos gamybiniams procesams ir procedūroms tobulinti, rengiant rekomendacijas, naujovių apžvalgas ir konsultacijas; teikiant bibliotekos paslaugas, didinant prieigą prie bibliotekose turimų žiniu, atskleidžiant turimus bibliotekose išteklius, jų visuomeninę vertę ir turinị. Viena bibliotekos veiklos sritis metodinè veikla - iš esmès remiasi moksline pažintine funkcija; praktikoje ji glaudžiai susijusi ir persipynusi su moksline veikla, nes abiejų šių veiklos sričių rezultatai vertinami remiantis naujoviškumo pozicijomis, matuojant jų reikšmingumą pagal tai, ar jų rezultatuose yra naujoviškumo elementu, padedančių augti bibliotekų veiklos efektyvumui ir kokybei.

Šiandien nèra aiškiai sutarta dèl ribos tarp "grynojo“ mokslinio tyrimo ir rinkos tyrimo. Bibliotekinès (kaip ir bet kurios kitos rinkodaros) užnugaryje visuomet galima pamatyti visą sociologinių mokslų kompleksą. Nors pagrindiniai rinkodaros objektai yra poreikis, pasiūla ir jų santykis, šių santykių pagrindas ne vien ekonominis: tai ir socialinès normos, socialiniai lūkesčiai, socialiniai vaidmenys, ir socialiniai mainai. Bibliotekinè rinkodara, kuri dažniausiai analizuoja bibliotekininko (bibliotekos) ir vartotojo socialinius vaidmenis, nustato šių socialinių veikẻjų tarpusavio lūkesčius, ieško efektyvių būdų juos tenkinti. Socialiniai mainai priklauso nuo pozicijų (demografiniu, ekonominių, politiniu, kultūrinių ir pan.), kurias atskiri individai užima visuomenëje, taip pat nuo bibliotekos turimų produktų ir paslaugu, kurias ji gali tokiems mainams pasiūlyti. Taigi akivaizdu, kad šie klausimai keliami ne tik rinkos, bet ir mokslinių tyrimų kontekste. Dèl to ir tai, kodèl konkretus tyrimas priskiriamas tam tikros rūšies tyrimams, dažnai priklauso ir nuo tyrèjo, jo žinių ir keliamų tikslų, tiksliau - jo mokëjimo sukurti tam tikrą „,sociologini požiūiti “ i tyrinëjamą problemą, gebëjimo atliekamą tyrimą padaryti įdomų platesnei auditorijai, ne tik konkrečiai bibliotekai. 
VB sektoriuje galima nujausti vadybinių kompetencijų stygių, ypač veiklos dokumentų rengimo srityje. Remiantis bibliotekų praktinès veiklos analizių duomenimis taip pat galima spèti, kad sektoriaus bibliotekoms vadovaujančių (ir veiklos dokumentus kuriančių) asmenų nuostatos dèl mokslo tiriamosios veiklos yra nenuoseklios: dažniau ji laikoma papildoma, šalutine, atsitiktine, tikimybine, atliekama, kai „reikia“, t. y. kai tokius veiksmus diktuoja išorès subjektai (bibliotekos savininkas, projektinès veiklos rèmëjas ar organizatorius, regioninis ar nacionalinis metodikos centras, konkurentas ar pažengęs šioje srityje partneris ir pan.). Dažniausiai siekiama „apsidrausti“ ir užsitikrinti, kad, esant būtinybei, galima būtų pavesti tam tikrus darbus konkrečiam darbuotojui, neturint tikslo sukonstruoti šios veiklos valdymo modelį, užtikrinantị sistemingą jos planavimą, organizavimą ir igyvendinimą.

Procesų valdymo teorijos ir praktikos klausimai bibliotekų vadybos srityje nagrinëjami retai, o ir valdymo teorijoje veiklos procesų ir valdymo procesų sąveikos mechanizmas išanalizuotas nepakankamai, tad ir mokslo tiriamosios veiklos valdymo modeliai bibliotekose dažniausiai nèra tikslingai ir profesionaliai kuriami ir dokumentuojami. Tikètina, jog dèl šios priežasties šie modeliai turètų būti neištobulinti, fragmentiški arba nenuoseklūs, neatspindintys to, kas svarbiausia. Ši aplinkybè taip pat gali prisidèti prie to, kad ir pati veikla taptų formali, neturinti didesnès praktinès reikšmès, nes realioje veikloje formaliai sukonstruotų modelių nepaisoma arba paisoma tik iš dalies. Situaciją labiausiai sunkina tai, kad neturime ir aiškiai, tiksliai apibrèžtų šio konkretaus proceso parametrų: neaiškus ir tiksliai neapibrežztas proceso turinys; nenustatyta tvarka ir seka, kaip turi vykti procesas; neaišku, kas yra tikrieji proceso dalyviai ir koks kiekvieno ju indèlis ir vaidmuo ji vykdant. Taigi per menkai išanalizuota mokslo tiriamosios veiklos situacija SVB sektoriuje yra akivaizdi problema.

Tyrimo tikslas - apibendrinti šešerių metų (2010-2015 m.) mokslo tiriamojo darbo patirtị SVB, išanalizuoti šiuo laikotarpiu atliktų mokslinių tyrimų ir kitos tiriamosios veiklos praktiką. 


\section{Tyrimo uždaviniai:}

1) išanalizuoti mokslo tiriamosios veiklos terminiją, vartojamą SVB veiklos dokumentuose, šios veiklos organizavimo ir valdymo viešosiose bibliotekose nuostatas ir jų reglamentavimo praktiką;

2) nustatyti, kokios mokslo tiriamosios veiklos formos (moksliniai tyrimai, rinkos tyrimai, tyrimai, reikalingi vadybiniams sprendimams priimti, analitinès ataskaitos) paplitusios SVB sektoriuje, ir įvertinti, kaip atlikti darbai atitinka kokybès kriterijus;

3) ištirti mokslo tiriamosios veiklos rezultatų sklaidos ir panaudojimo patirti viešosiose bibliotekose;

4) išsiaiškinti mokslo tiriamosios veiklos plètros galimybes viešosiose bibliotekose.

\section{Pagrindines tyrimo squokos}

Analitine ataskaita - dokumentas, kuriame pateikiamas išsamus studijuojamo objekto ar nagrinejjamo klausimo tyrimas: argumentuojamas darbo aktualumas, nusakomas jo tikslas ir pagrindiniai uždaviniai, apibūdinami šaltiniai, kuriais remiantis tyrinëjamas klausimas ar objektas, analizuojamos svarbiausios temos, pateikiamos argumentuotos išvados ir gautų rezultatų produktyvumo ịvertinimas, tolesnès raidos prognozè. Svarbiausias analitinès ataskaitos elementas yra analizès metodas; dažniausias veiklos analizès pagrindas - veiklos rezultatų ir siekiamų (planinių) tikslų palyginimas.

Dalyvavimo tyrimuose funkcija - atlikti dalị su tyrimu susijusių darbu, pavyzdžiui, parengti anketą, surinkti duomenis, apibendrinti duomenis ir pan.

Informacinè analitinè veikla - profesinè veikla, kurią sudaro tikslinga duomenų (informacijos) paieška, surinkimas, kokybiško informacijos turinio perteikimas (duomenu analizès ar jų apdorojimo būdu) ir produktyvus tokios informacijos panaudojimas profesiniams uždaviniams spręsti. Socialineje srityje, politikoje ir versle informaciniai analitiniai darbai skirti 
visų pirma vadybiniams poreikiams tenkinti, t. y. ịvairių ịstaigu, visuomeninių, verslo ir politinių organizacijų vadovų reikmėms.

Mokslo tiriamoji veikla - sistemingai atliekamas kūrybinis pažinimo darbas, apimantis bibliotekose atliekamus mokslinius tyrimus, rinkos tyrimus ir (arba) tyrimus, reikalingus vadybiniams sprendimams parengti, ivvairius analitinius darbus, kuriais siekiama spręsti praktinius uždavinius, taip pat veiklas skleidžiant informaciją apie tiriamųjų darbų rezultatus ir integruojant juos į bibliotekų praktiką.

Rinkos tyrimas ir viešosios nuomonès apklausa - rinkos galimybiu, informuotumo, prekių ir paslaugu priimtinumo ir pažinimo, vartotoju pirkimo ịpročių tyrimas, siekiant skatinti pardavimą ir kurti naujas prekes ir paslaugas, ịskaitant statistinę rezultatų analizę; viešosios nuomonès apie politiką, ekonomiką ir socialines problemas tyrimas ir statistinè jo rezultatų analizè.

Taikomieji moksliniai tyrimai-eksperimentiniai ir (arba) teoriniai pažinimo darbai, atliekami norint gauti naujų žinių ir pirmiausia skiriami specifiniams praktiniams tikslams pasiekti arba uždaviniams spręsti.

Tyrimu vykdymo funkcija - savarankiškai atlikti visus su tyrimu susijusius darbus (parengti tyrimo programą ir dokumentus, surinkti ir apibendrinti duomenis, parengti tyrimo ataskaita).

\subsection{Tyrimo metodika}

Tyrimui atlikti pasirinktas koordinuotojo tyrimo būdas. Darbas atliktas dalyvaujant LNB (tyrimui vadovaujanti ir tyrimą koordinuojanti institucija), bendradarbiaujant (partnerių teisèmis) su apskričių viešosiomis bibliotekomis (5):

- Kauno apskrities viešaja biblioteka,

- Klaipèdos apskrities Ievos Simonaitytès viešaja biblioteka,

- Panevėžio apskrities Gabrielès Petkevičaitės-Bitès viešąja biblioteka,

- Šiauliu apskrities Povilo Višinskio viešaja biblioteka ir

- Vilniaus apskrities Adomo Mickevičiaus viešaja biblioteka (VAVB). 
Parengta originali tyrimo metodika; tyrimo kartotinumo galimybę užtikrina parengtos išsamios rekomendacijos [18], kuriose pateiktas tyrimo pagrindimas, tikslai ir uždaviniai; duomenų palyginamumą užtikrina unifikuoti duomenu registravimo blankai. 8 priedus (12 dokumentu) parengè LNB tyrimo koordinatorius, 1 dokumentą (7 prieda) parenge VAVB specialiste. Tyrimo dokumentai buvo aptarti ir suderinti su visais tyrimo dalyviais ir, suderinus su tyrimo partneriais, pagal pasiūlymus patikslinti.

Tyrimas atliktas naudojant kiekybinius ir kokybinius tyrimo metodus. Buvo atlikta bibliotekų veiklą reglamentuojančių dokumentu (bibliotekų nuostatų, struktūrinių padalinių, personalo pareigybių nuostatu) ir jų turinio analizė, mokslo tiriamosios veiklos proceso organizavimo SVB duomenų (struktūrų formavimo, funkcijų pasiskirstymo ir pan.) analizė; SVB savarankiškai parengtų mokslo tiriamųjų darbų (jų tematikos, formos, apimties, paskirties aspektu, pagal iš anksto parengtus kriterijus) analizé ir vertinimas; kitų institucijų tiriamuoju laikotarpiu SVB tyrimo lauke parengtų darbų statistinių duomenu analizè pagal parengtą unifikuotą formą; SVB atliktų mokslo darbų ir jų rezultatų sklaidai skirtų priemonių analizė, SVB parengtų metų veiklos ataskaitų analizè ir vertinimas (pagal iš anksto parengtus vertinimo kriterijus); bibliotekų vadovu ir darbuotoju, kurių funkcijos susijusios su tiriamosios veiklos organizavimu, valdymu ir igyvendinimu, anketinè apklausa.

Biblioteku veiklos dokumentus analizavo AVB tyrëjai. Nuostatai, kiti tyrimui reikalingi dokumentai, kurie rasti viešai prieinami interneto svetainèse (59 SVB), buvo peržiūrèti de visu, išanalizuotas jų turinys; išrašus iš struktūrinių padalinių ir pareigybių nuostatu, kuriuose reglamentuojamos tiriamosios veiklos funkcijos, taip pat duomenis apie šias funkcijas vykdančius darbuotojus pateikè regionų SVB (54 SVB), surašydamos juos ị tam parengtus unifikuotus duomenų lapus. Anketuoti buvo parengti originalūs klausimynai (pagrindinè rengèja - LNB, žr. 8, 9 priedus), jie aptarti ir suderinti su AVB specialistais. 
Po konsultacijų su AVB tyrëjais šio tyrimo kontekste nutarta nevertinti ir i tiriamųjų darbų sąrašus neįtraukti kraštui (bendruomenėms, kaimams, istorijoms, atskiriems kultūros ar atminties objektams) dokumentuoti skirtų darbų, taip pat ir kitų bibliotekinei kraštotyrai priskiriamu darbų (bibliotekų istorijų, metraščiu, kronikų ir pan.) dèl jų išskirtinumo ir su tuo susijusio poreikio sukurti atskirą šių darbų vertinimo metodiką. Tyrëjų manymu, būtų racionalu atskirai patyrinèti SVB krašto dokumentavimo darbų rengimo praktiką, nes ši veikla yra, o ir ateityje turètų būti viena reikšmingiausių šių institucijų veiklos sričių.

SVB metu veiklos ataskaitos šiame tyrime vertinamos kaip dokumentas, kuris turètu atitikti analitinés ataskaitos kategorijai priskiriamus darbus. Remiantis šiam dokumentui parengti skirtomis rekomendacijomis $[4,5,6,7,8,9]$ ir viešujų biblioteku praktika, daroma prielaida, jog tai vienas iš pagrindinių bibliotekų veiklos įsivertinimo būdų, kurio rezultatais remiamasi formuojant bibliotekų vadybos kultūrą, instrumentas, padedantis suvokti savo instituciją kaip visumą, ir sutarti dèl jos tobulinimo krypčių.

Vertinant šiuos darbus remtasi informacinio analitinio darbo žanrui keliamais metodologiniais reikalavimais, kurie suformuluoti kaip tam tikri principai. Svarbiausi - moksliškumas, kompleksiškumas, sistemingumas, objektyvumas, tikslumas, patikimumas, veiksmingumas, operatyvumas ir efektyvumas. Vadovautasi nuostata, kad, nepaisant šių reikalavimu, analizès tikslai iš esmès lieka nepasiekti, o jos rezultatai negali būti efektyviai panaudoti pagrindžiant organizacijos plètros strategijos ar politikos sprendimus.

Buvo sutarta, kad veiklos analizé laikoma tinkamai atliekama, jeigu:

- vertinami reiškiniai, procesai, veiklos rezultatai susieti su valstybëje (regione, savivaldai priskirtoje teritorijoje) igyvendinama ekonomine, socialine, ekologine, kultūros politika ir galiojančiais teisès aktais; 
- analizè paremta mokslo žiniomis, t. y. analizuojamos srities teorinèmis nuostatomis, paisoma toje veiklos srityje nustatytų dėsnių, pritaikant mokslo, technikos ir technologijos naujoves, naudojantis pažangiąja patirtimi ir naujausių tyrinèjimų rezultatais;

- analizé yra kompleksiné; analizuojamos visos veiklos grandys, visų organizacijos struktūrinių darinių veikla ir ịvertinami atskirų organizacijos veiklų priežastiniai priklausomybès ryšiai;

- kiekvienas analizuojamas objektas vertinamas kaip sudètinga dinamiška sistema, kurią sudaro tam tikru būdu tarpusavyje ir su išorine aplinka susiję elementai (sistemingumo principas); kiekvienas tų elementų taip pat turètų būti analizuojamas atsižvelgiant ị analizuojamo objekto vidinius ir išorinius ryšius, kiekvieno iš tų elementų tarpusavio priklausomybę ir tarpusavio pavaldumą; - veiklos analizè yra objektyvi, konkreti ir tiksli, paremta patikima, patikrinta informacija, realiai atitinkančia objektyvią tikrovę, o išvados - tiksliais skaičiavimais (organizacijoje, kurios veikla analizuojama, turètų būti nuolat tobulinami reikalavimai, keliami veiklos duomenų apskaitai, ir analizės metodika);

- analizė yra veiksminga; ji turi daryti įtaką organizacijos veiklai ir jos rezultatams, padèti atskleisti darbo procesų, technologijos ar kitokių institucijoje padarytu sprendimu spragas, netikslumus, aplaidumą darbe ir pan.; taip pat svarbu, kad apie analizės rezultatus būtų informuota ir organizacijos vadovybė, nes tik taip jos rezultatai galètų būti praktiškai naudojami organizacijos vadybai, rengiant konkrečias priemones, koreguojant ir tikslinant plano duomenis; priešingu atveju analizès tikslai taip pat nepasiekiami;

- analizè atliekama planingai ir sistemingai; tokia veikla turi būti planuojama, konkretūs ịpareigojimai paskirstomi veikiantiems asmenims (pareigybėms) ir užtikrinama jų vykdymo kontrolè.

Darbe analizuojamos SVB dvejų metų (2010 m. ir 2015 m. - palyginti ir pokyčiams ịvertinti) veiklos ataskaitos. 
Atliekant tyrimą analizuotos ataskaitos buvo sugrupuotos pagal atskirų regionų teritorijose veikiančias SVB; jas vertino AVB tyrëjai. Ir nors ataskaitu kokybė vertinta pagal tyrimo koordinatoriaus parengtus, visų tyrimo dalyvių apsvarstytus ir suderintus vienodus vertinimo kriterijus, vis dèlto galima tikètis tam tikrų, tiesa, nereikšmingų vertinimo skirtumų, o tai apskritai būdinga ekspertų vertinimui. Tai neišvengiama dèl skirtingos tyrimą atliekančių vertintojų profesinès patirties, igūdžiu ir kompetencijų informacinès analitinès veiklos srityje, taip pat dèl ekspertų skirtingu charakterio savybių: reiklumo, principingumo, pagaliau sukauptų žinių kiekvienoje metų veiklos ataskaitoje analizuojamų veiklų srityje.

Vertinti du pagrindiniai šių darbų komponentai: bibliotekos veiklos turinio (atskirų veiklos sričiu) analizès kokybè ir darbo įforminimo, jo struktūros pasirinkimo ir pateikimo (vaizdinès raiškos, iliustravimo) kokybė. Ir šios dalys, ir visas konkrečioje SVB atliktas darbas buvo vertinamas pagal 5 balų sistemą (1 lentelè) papildant šią sistemą nuliniu vertinimu (vertinimo kriterijus 2 r. 5 priede).

1 lentelè. Metu veiklos ataskaitu kokybès vertinimas (balais)

\begin{tabular}{|c|c|c|c|c|c|c|}
\hline Vertinimas & Labai gerai & Gerai & Vidutiniškai & Silpnai & Nepatenkinamai & Nevertinta \\
\hline Balų skaičius & 5 & 4 & 3 & 2 & 1 & 0 \\
\hline
\end{tabular}

\subsection{Tyrimo dalyviai}

Tyrimo duomenys buvo renkami iš 59 SVB (98,3 proc. viso sektoriaus bibliotekų tinklo, $\mathrm{N}=60$ ); jų rinkimą organizavo, ì parengtus duomenų blankus ịrašè ir susistemino AVB specialistai (tyrimo partneriai). Iš atskirų SVB surinkta informacija (duomenų blankai) persiųsti LNB, čia sudarytas bendras duomenu masyvas; jo pagrindu parengta bendroji tyrimo ataskaita. AVB (5) kiekviena atskirai apibendrino joms priskirtu SVB pateiktus duomenis (duomenis apie regionu bibliotekas žr. 2 lenteleje), savarankiškai parengè tyrimo dalis, atskleidžiančias kiekvieno regiono SVB situaciją atsižvelgiant ị tiriamą problemą. 
6 SVB (10,2 proc. visų tyrime dalyvavusių biblioteku, N=59) pateikè ne visus tyrimo dokumentuose numatytus surinkti ir veiklos analizei reikiamus duomenis. Klaipėdos regiono bibliotekos (11 SVB, arba 18,6 proc. visų tyrime dalyvavusių bibliotekų, $N=59$ ) nepateikè duomenų apie SVB savarankiškai atliktus mokslo tiriamajai veiklai priskiriamus darbus.

Tyrimu siekta nuodugniai išsiaiškinti, kaip SVB sukonstruotas mokslo tiriamosios veiklos organizavimo modelis, todèl buvo numatyta ne tik nustatyti, kurioms pareigybèms ši veikla pavedama, bet ir einančių šias pareigas darbuotojų formalų pasirengimą arba potencialias žinias, reikalingas tinkamai atlikti šiai veiklai priskiriamus darbus. Tam bibliotekos buvo prašytos pateikti tokius duomenis - surašyti juos specialiai parengtuose duomenu blankuose (1 priedas, 2 ir 3 lenteles).

Apklausai pasirinkta tikslinè atranka: vienas klausimynas buvo siunčiamas biblioteku vadovams, kitas - bibliotekų darbuotojams. Darbuotojų sąrašas buvo suderintas su AVB tyrëjais ir sudarytas remiantis biblioteku pateiktais duomenimis apie tuos iš jų, kuriems pagal pareigines instrukcijas SVB veiklos dokumentuose nustatyta mokslo tiriamosios veiklos funkcija.

Anketineje apklausoje iš 59 SVB vadovų (direktorių pareigybès) dalyvavo ir ị klausimus atsakè 43, arba 72,9 proc. visu tyrime dalyvavusių biblioteku vadovu (2 lentele); aktyviausi tyrimo dalyviai regionu lygmeniu Šiaulių regione (81,8 proc. visų tyrime dalyvavusių regiono bibliotekų, N=11), apskričių lygmeniu - Marijampolès apskrities (Kauno regionas) direktoriai (100,0 proc. visu apskrities SVB, N=5); pasyviausi regionu lygmeniu - Panevezžio regiono SVB (54,5 proc. visų tyrime dalyvavusių SVB, N=59), apskričių lygmeniu - Utenos apskrities SVB (Panevėžio regionas) vadovai (20,0 proc. visų tyrime dalyvavusių biblioteku, $\mathrm{N}=5$ ). 
2 lentelè. Dalyvavusiu tyrime SVB ir ju vadovu (direktoriu, atsakiusiu i anketos klausimus, skaičius ir dalis (proc.) SVB tinklu struktūroje

\begin{tabular}{|c|c|c|c|c|c|c|c|}
\hline \multirow{2}{*}{$\begin{array}{l}\text { Eil. } \\
\text { Nr. }\end{array}$} & \multirow[t]{2}{*}{ Regionas } & \multirow[t]{2}{*}{ Apskritis } & \multirow{2}{*}{$\begin{array}{l}\text { Yra } \\
\text { SVB } \\
\text { (skai- } \\
\text { čius) }\end{array}$} & \multicolumn{2}{|c|}{ Tyrime dalyvavo SVB } & \multicolumn{2}{|c|}{$\begin{array}{c}\text { Tyrime dalyvavo SVB } \\
\text { vadovų (skaičius ir } \\
\text { dalis (proc.) vadovų } \\
\text { struktūroje) }\end{array}$} \\
\hline & & & & $\begin{array}{l}\text { tyrinèta } \\
\text { veikla }\end{array}$ & $\begin{array}{c}\text { dalis } \\
\text { (proc.) } \\
\text { SVB tinkle }\end{array}$ & $\begin{array}{c}\text { atsakè ì } \\
\text { klausimus }\end{array}$ & $\begin{array}{l}\text { atsake } \\
\text { vadovų } \\
\text { (proc.) }\end{array}$ \\
\hline \multirow[t]{3}{*}{1.} & Kauno & & 13 & 13 & 100,0 & 10 & 76,9 \\
\hline & & Kauno & 8 & 8 & 100,0 & 5 & 62,5 \\
\hline & & Marijampolès & 5 & 5 & 100,0 & 5 & 100,0 \\
\hline \multirow[t]{3}{*}{2.} & Klaipèdos & & 11 & 11 & 100,0 & 8 & 72,7 \\
\hline & & Klaipèdos & 7 & 7 & 100,0 & 5 & 75,0 \\
\hline & & Tauragès & 4 & 4 & 100,0 & 3 & 71,4 \\
\hline \multirow[t]{3}{*}{3.} & Panevėžio & & 12 & 11 & 91,7 & 6 & 54,5 \\
\hline & & Panevėžio & 6 & 6 & 100,0 & 5 & 83,3 \\
\hline & & Utenos & 6 & 5 & 83,3 & 1 & 20,0 \\
\hline \multirow[t]{3}{*}{4.} & Šiaulių & & 11 & 11 & 100,0 & 9 & 81,8 \\
\hline & & Šiaulių & 7 & 7 & 100,0 & 6 & 85,7 \\
\hline & & Telšių & 4 & 4 & 100,0 & 3 & 75,0 \\
\hline \multirow[t]{3}{*}{5.} & Vilniaus & & 13 & 13 & 100,0 & 10 & 76,9 \\
\hline & & Vilniaus & 8 & 8 & 100,0 & 7 & 87,5 \\
\hline & & Alytaus & 5 & 5 & 100,0 & 3 & 60,0 \\
\hline \multicolumn{3}{|c|}{ Iš viso } & 60 & 59 & 98,3 & 43 & 72,9 \\
\hline
\end{tabular}

Anketinëje darbuotojų apklausoje dalyvavo 349 SVB darbuotojai (3 lentelè). Šios tiriamuju respondentų imties dydis apskaičiuotas pagal formulę $n=1 /\left(\Delta^{2}+1 / N\right)$ ir proporcingai paskirstytas kiekvienai AVB, atsižvelgiant ị šiuose regionuose tiriamojoje veikloje dalyvaujančių darbuotoju skaičių (duomenys buvo surinkti iš anksto, jais remiantis anketų skaičius paskirstytas teritorijoje). Generalinè visuma - profesionaliųjų bibliotekininkų pareigas ëjusių SVB darbuotojų skaičius $2016 \mathrm{~m}$. ( $\mathrm{N}=2471)$, o pagrindiniai apklausos subjektai - pagrindinių SVB sistemų (toliau - centriniu) biblioteku darbuotojai (N=991). Pastaroji grupé apklaustų ir atsakiusių i anketos klausimus SVB darbuotojų struktūroje sudaro 66,8 proc. visų tyrimo dalyvių (233 darbuotojai, $\mathrm{N}=349$ ), o teritoriniuose padaliniuose dirbantis personalas $-30,4$ proc. visų tyrimo dalyvių (106 darbuotojai, $\mathrm{N}=349$ ). 
Atliekant tyrimą buvo pasiekti ir apklausti SVB sistemose dirbantys asmenys, kuriems mokslo tiriamoji veikla privaloma (nustatyta jų veiklą reglamentuojančiuose dokumentuose) arba, remiantis SVB pateiktais duomenimis, jie vienaip ar kitaip praktinëje veikloje susiduria su bent viena iš darbe tyrinëjamų šios veiklos krypčių: moksliniais tyrimais, rinkos tyrimais ar informacine analitine veikla.

3 lentelè. Dalyvavusiu tyrime SVB ir ju darbuotoju, atsakiusiu i anketos klausimus, skaičius ir dalis (proc.) SVB struktüroje

\begin{tabular}{|c|c|c|c|c|c|c|c|c|c|c|c|}
\hline \multirow{4}{*}{$\begin{array}{l}\text { Eil. } \\
\text { Nr. }\end{array}$} & \multirow{4}{*}{ Regionas } & \multirow{4}{*}{ Apskritis } & \multirow{4}{*}{$\begin{array}{l}\text { Yra } \\
\text { SVB } \\
\text { (skai- } \\
\text { čius) }\end{array}$} & \multicolumn{8}{|c|}{ Tyrime dalyvavo darbuotojų } \\
\hline & & & & \multirow[b]{3}{*}{ 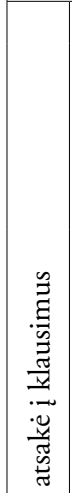 } & \multirow{3}{*}{ 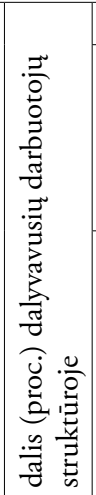 } & \multicolumn{6}{|c|}{ iš jų } \\
\hline & & & & & & \multicolumn{2}{|c|}{$\begin{array}{l}\text { dirba } \\
\text { viešosiose } \\
\text { bibliote- } \\
\text { kose }\end{array}$} & \multicolumn{2}{|c|}{$\begin{array}{c}\text { dirba } \\
\text { teritori- } \\
\text { niuose } \\
\text { padali- } \\
\text { niuose }\end{array}$} & \multicolumn{2}{|c|}{$\begin{array}{c}\text { nenurod } \\
\text { darbo } \\
\text { vietos }\end{array}$} \\
\hline & & & & & & 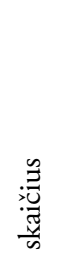 & 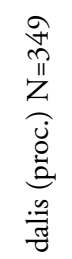 & 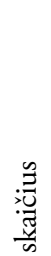 & 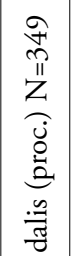 & 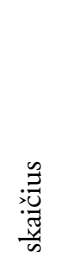 & 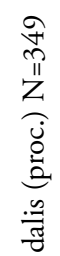 \\
\hline \multirow[t]{3}{*}{1.} & Kauno & & 13 & 58 & 16,6 & 52 & 15,0 & 6 & 1,7 & & \\
\hline & & Kauno & 8 & & & & & & & & \\
\hline & & Marijampolès & 5 & & & & & & & & \\
\hline \multirow[t]{3}{*}{2.} & Klaipèdos & & 11 & 76 & 21,8 & 45 & 12,9 & 27 & 7,7 & 4 & 1,1 \\
\hline & & Klaipèdos & 7 & & & & & & & & \\
\hline & & Tauragès & 4 & & & & & & & & \\
\hline \multirow[t]{3}{*}{3.} & Panevèžio & & 12 & 76 & 21,8 & 49 & 14,0 & 26 & 7,4 & 1 & 0,3 \\
\hline & & Panevėžio & 6 & & & & & & & & \\
\hline & & Utenos & 6 & & & & & & & & \\
\hline \multirow[t]{3}{*}{4.} & Šiaulių & & 11 & 57 & 16,3 & 37 & 10,6 & 20 & 5,7 & & \\
\hline & & Šiaulių & 7 & & & & & & & & \\
\hline & & Telšiu & 4 & & & & & & & & \\
\hline \multirow[t]{3}{*}{5.} & Vilniaus & & 13 & 82 & 23,5 & 50 & 14,3 & 27 & 7,7 & 5 & 1,4 \\
\hline & & Vilniaus & 8 & & & & & & & & \\
\hline & & Alytaus & 5 & & & & & & & & \\
\hline \multicolumn{3}{|c|}{ Iš viso } & 60 & 349 & 100,0 & 233 & 66,8 & 106 & 30,4 & 10 & 2,8 \\
\hline
\end{tabular}




\section{Anketines apklausos dalyviai}

\section{Biblioteku vadovai}

Išsimokslinimas. Tyrime dalyvavusių $(\mathrm{N}=43)$ vadovų grupëje daugiausia (40, arba 93,0 proc. visų šios grupès dalyviu) igijusių aukštąj išsimokslinimą (1 pav.); kiek daugiau (+9,6 proc.) vadovų, igijusių formalujji bibliotekininkystès, informacijos ir komunikacijos krypčių išsimokslinimą, nei vadovų, igijusių kitų sričiu išsimokslinimą. Be to, dauguma bibliotekininkystės, informacijos ir komunikacijos srities išsimokslinimą igijusių vadovų (15, arba 65,2 proc. visų šios grupès dalyvių) mokymo programas baigè iki 1995 metu.

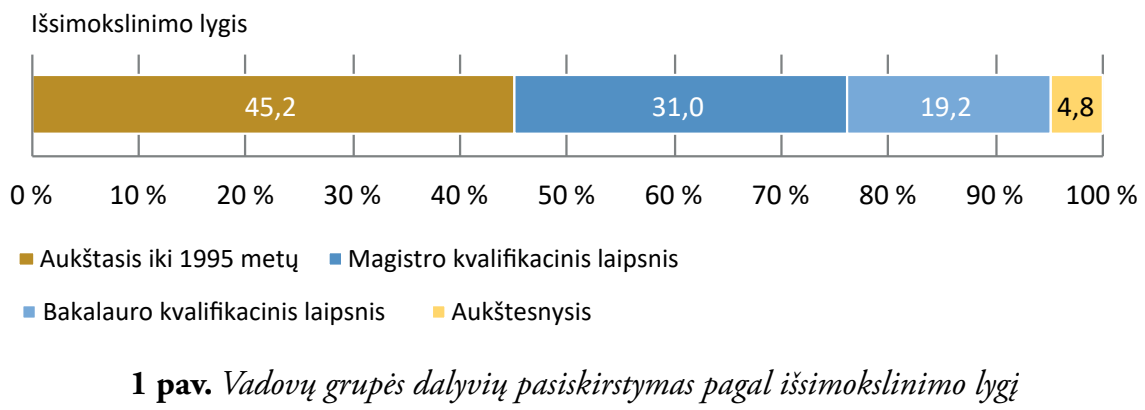

Vèliau nei 1995 m. baigusių bibliotekininkystès, informacijos ir komunikacijos krypčiu studijų programas ir ịgijusių magistro bei bakalauro kvalifikacinius laipsnius šiame pogrupyje palyginti nedaug - 7 asmenys (arba 16,7 proc. visu tyrimo dalyviu); palyginti su pastaraisiais, dvigubai daugiau (14, arba 33,3 proc.) yra magistro ir bakalauro kvalifikacinius laipsnius igijusių asmenų, baigusių kitų sričių studijų programas (4 lentele ir 2 pav.). 
4 lentelè. Vadovu grupès dalyviu pasiskirstymas pagal išsimokslinimo lygi

\begin{tabular}{|c|c|c|c|c|c|c|c|}
\hline \multirow{3}{*}{$\begin{array}{l}\text { Eil. } \\
\mathrm{Nr} .\end{array}$} & \multirow{3}{*}{ Išsimokslinimas } & \multirow{2}{*}{\multicolumn{2}{|c|}{ Iš viso }} & \multicolumn{4}{|c|}{ Iš jų } \\
\hline & & & & \multicolumn{2}{|c|}{$\begin{array}{l}\text { bibliotekinin- } \\
\text { kystès, informa- } \\
\text { cijos ir komun- } \\
\text { kacijos krypties }\end{array}$} & \multicolumn{2}{|c|}{ kitų sričių } \\
\hline & & $\begin{array}{l}\text { vadovų } \\
\text { skaičius }\end{array}$ & proc. & $\begin{array}{l}\text { vadovŭ } \\
\text { skaičius }\end{array}$ & proc. & $\begin{array}{l}\text { vadovų } \\
\text { skaičius }\end{array}$ & proc. \\
\hline 1. & Aukštasis iki 1995 m. & 19 & 45,2 & 15 & 35,7 & 4 & 9,5 \\
\hline 2. & Magistro kvalifikacinis laipsnis & 13 & 31,0 & 4 & 9,5 & 9 & 21,4 \\
\hline 3. & Bakalauro kvalifikacinis laipsnis & 8 & 19,0 & 3 & 7,1 & 5 & 11,9 \\
\hline 4. & Aukštesnysis išsimokslinimas & 2 & 4,8 & 1 & 2,4 & 1 & 2,4 \\
\hline \multicolumn{2}{|c|}{ Iš viso } & 42 & 100,0 & 23 & 54,8 & 19 & 45,2 \\
\hline \multicolumn{2}{|c|}{ Nenurodè } & 1 & 2,3 & & & & \\
\hline
\end{tabular}

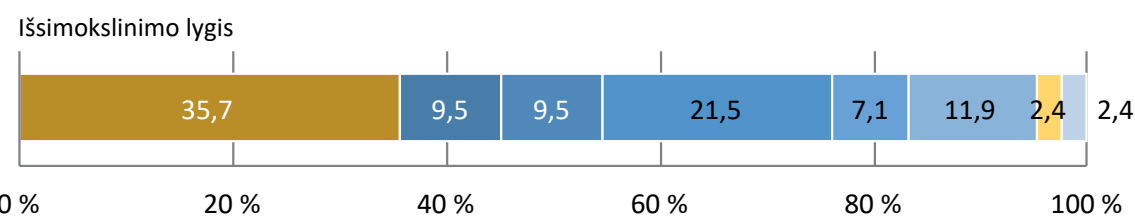

- Aukštasis iki 1995 metų, bibliotekininkystès studijos

Aukštasis iki 1995 metų, kitos sritys

- Magistro, bibliotekininkystès ir informacijos kryptis

- Magistro, kitos sritys

- Bakalauro, bibliotekininkystès ir informacijos kryptis

Bakalauro, kitos sritys

Aukštesnysis, bibliotekininkystès studijos

Aukštesnysis, kitos sritys

\section{2 pav. Vadovu grupès dalyviu pasiskirstymas pagal ǐssimokslinimo sritis}

Tarp kitu sričių specialybes igijusių asmenų bibliotekų vadovais daugiausia dirba švietimo ir ugdymo srities specialistu (7, arba 16,6 proc. visų tyrimo dalyviu), viešojo administravimo ir vadybos specialistu (4 asmenys, arba 9,5 proc.) ir ekonomikos, žurnalistikos ar kultūros studijų krypčių mokymo programas ( 4 asmenys, arba 9,5 proc.) baigusių specialistų.

Darbo patirtis. Vidutinis tyrime dalyvavusių SVB vadovų darbo stažas einant pareigas, kurias jie ejo tyrimo metu, - 13,4 metų. Pagal išdirbtus metus vadovus galima suskirstyti i 3 beveik vienodo dydžio grupes; didesnę grupę sudaro mažiausią darbo patirtị (iki 10 metu) turintys vadovai (19, arba 44,2 proc. visų grupès dalyviu); daugiau nei trečdali 
(15, arba 34,9 proc. visų grupès dalyvių) sudaro iki 20 metų darbo patirtį turintys vadovai; penktadali ( 9 , arba 20,9 proc. visų grupès dalyviu) sudaro daugiau nei 20 metų darbo patirtį turintys bibliotekų vadovai (3 pav.).

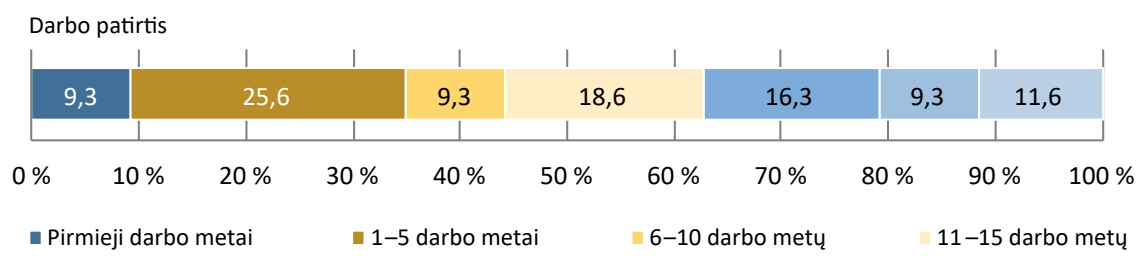

3 pav. Vadovu grupès dalyviu pasiskirstymas pagal darbo stažq

Amžius. Vidutinis dalyvavusių tyrime vadovų amžius - 51,5 metų. Didžiausią dali grupèje (23, arba 53,5 proc.) sudaro 51-60 metu amžiaus asmenys, dar penktadali (11, arba 25,6 proc.) - 41-50 metų amžiaus atstovai (4 pav.). Iki 40 metų amžiaus vadovu yra 4 (arba 9,4 proc. visų tyrime dalyvavusių SVB vadovu). Vyresnių nei 61 metų taip pat nedaug (5, arba 11,6 proc.). Vyresnio amžiaus (51-60 metu) vadovu grupëje didesnę pusę $(65,2$ proc.) sudaro vadovai, turintys formalujjị bibliotekininkystès, informacijos ir komunikacijos krypčių ǐssimokslinimą.

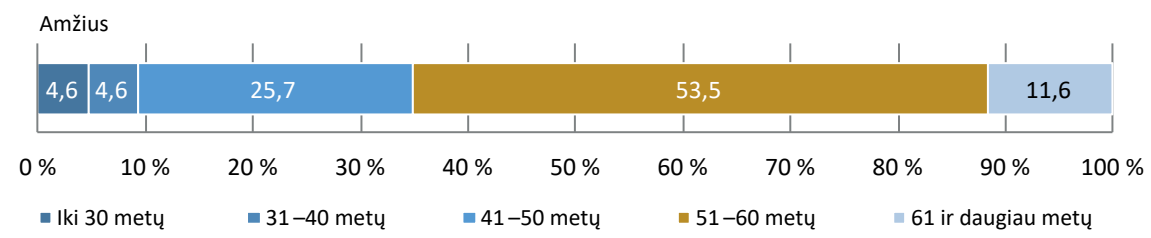

4 pav. Vadovu grupes dalyviu pasiskirstymas pagal amžiu

\section{Biblioteku darbuotojai}

Išsimokslinimas. Duomenis apie išsimokslinimą pateikè 345 asmenys iš 349 (arba 98,8 proc. visų tyrimo dalyviu). Du trečdaliai apklausoje dalyvavusių darbuotojų (68,1 proc., arba 235 darbuotojai) yra igiję aukštajji (universitetinị ir koleginị) išsimokslinimą, trečią̧ą dalị apklaustụjų (31,9 proc., arba 110 tyrimo dalyvių) sudaro aukštesnịji ir specialųji 
vidurinị išsimokslinimą igiję SVB specialistai. Daugiausia tarp aukštą̧j išsimokslinimą igijusių specialistų mokymo programas yra išklausę iki 1995 m. (34,3 proc., arba 118 tyrimo dalyvių); bakalauro kvalifikacini laipsnị igiję penktadalis (21,7 proc., arba 75), magistro kvalifikacinį laipsnị mažiau nei dešimtadalis (7,8 proc., arba 27$)$ tyrimo dalyvių. Aukštesnịji išsimokslinimą igiję SVB specialistai sudaro 28,1 proc. (97) visų tyrimo dalyvių; nedidelè dalis (3,8 proc., arba 13$)$ tyrimo dalyvių yra igiję specialụji vidurinị išsimokslinimą ( 5 lentelè, 5 pav.).

5 lentelè. Tyrimo dalyviu (darbuotoju) pasiskirstymas pagal išsimokslinimo lygi

\begin{tabular}{|c|l|r|r|}
\hline $\begin{array}{c}\text { Eil. } \\
\text { Nr. }\end{array}$ & \multicolumn{1}{|c|}{ Išsimokslinimo lygis } & $\begin{array}{c}\text { Tyrimo } \\
\text { dalyvių } \\
\text { skaičius }\end{array}$ & $\begin{array}{c}\text { Tyrimo da- } \\
\text { lyvių dalis } \\
\text { (proc.) grupés } \\
\text { struktūroje }\end{array}$ \\
\hline 1. & Aukštasis išsimokslinimas & $\mathbf{2 3 5}$ & $\mathbf{6 8 , 1}$ \\
\hline $\mathbf{1 . 1 .}$ & Universitetinis, igytas iki 1995 metų & 118 & 34,3 \\
\hline $\mathbf{1 . 2 .}$ & Igytas bakalauro kvalifikacinis laipsnis & 75 & 21,7 \\
\hline $\mathbf{1 . 3 .}$ & Igytas magistro kvalifikacinis laipsnis & 27 & 7,8 \\
\hline $\mathbf{1 . 4 .}$ & Igytas profesinio bakalauro kvalifikacinis laipsnis & 15 & 4,3 \\
\hline $\mathbf{2 .}$ & Igytas aukštesnysis išsimokslinimas & $\mathbf{9 7}$ & $\mathbf{2 8 , 1}$ \\
\hline 3. & Igytas specialusis vidurinis išsimokslinimas & $\mathbf{1 3}$ & $\mathbf{3 , 8}$ \\
\hline 4. & Igytas kitas išsimokslinimo lygis (bendrojo lavinimo) & $\mathbf{0}$ & $\mathbf{0 , 0}$ \\
\hline Iš viso atsake & 345 & 100,0 \\
\hline Duomenų apie išsimokslinimą nepateike & 4 & 1,1 \\
\hline Iš viso tyrimo dalyvių & 349 & \\
\hline
\end{tabular}

Išsimokslinimo lygis

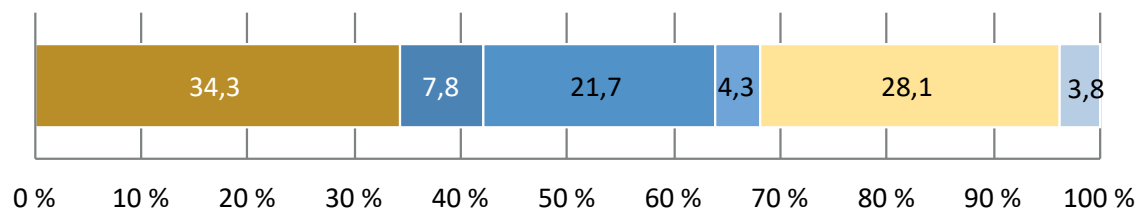

- Aukštasis iki 1995 metų

- Bakalauro kvalifikacinis laipsnis

- Magistro kvalifikacinis laipsnis

Aukštesnysis

- Profesinio bakalauro kvalifikacinis laipsnis

Specialusis vidurinis

5 pav. Grupès dalyviu (darbuotoju) pasiskirstymas pagal išsimokslinimo lygi (proc.) 
Taigi pagal išsimokslinimo sritis daugiau buvo apklausta bibliotekininkystès, informacijos ir komunikacijos (BIK) krypties programas baigusių specialistų (69,0 proc.), trečdalị (31,0 proc.) sudaro kitų specialybių programas studijavę bibliotekų darbuotojai.

BIK programas baigusiu specialistu grupejje yra du kartus daugiau asmenu (+80, arba $+50,3$ proc.), studijavusių specialybę aukštosiose mokyklose nei igijusių aukštesnịji šios srities išsimokslinimą. BIK specialistu, turinčiu aukštąji išsilavinimą, grupeje daugiau darbuotojų, baigusiu aukštąsias mokyklas iki $1995 \mathrm{~m}$. (62,3 proc. šios grupès dalyviu ( $\mathrm{N}=159)$; naujesnes studiju programas baigusiu $\mathrm{BIK}$ specialistu dalis sudaro 37,7 proc. $(\mathrm{N}=159)$.

Kitų specialybių (ne BIK) išsimokslinimą igijusių darbuotojų grupeje darbuotojai, igiję aukštąji išsimokslinimą, sudaro 71,0 proc. $(\mathrm{N}=107)$, aukštesnịji ir specialųji vidurinị kitu sričių ǐssimokslinimą igiję darbuotojai sudaro 29,0 proc. ( $\mathrm{N}=107)$ visos šios informantu grupès.

Darbo patirtis. Vidutinè tyrime dalyvavusių SVB darbuotoju darbo trukmè einant tas pareigas, kurias jie ejjo tyrimo metu, - 20,8 metu. Daugiau negu pusè (186, arba 53,6 proc.) tiriamosios grupès dalyvių eina šias pareigas daugiau nei 20 metu; naujokai, dirbantys pirmus penkerius metus, sudaro kiek mažiau nei penktadali - 57 asmenys, arba 16,5 proc. visų tyrimo dalyvių. Dar 36, arba 10,1 proc. tyrime dalyvaujančių darbuotoju grupess sudaro asmenys, dirbantys bibliotekose pirmą dešimtmetį; 67, arba 19,3 proc., - darbuotojai, kurių darbo trukmè bibliotekose ir einant šias pareigas jau yra nuo 11 iki 20 metu ( 6 pav.).

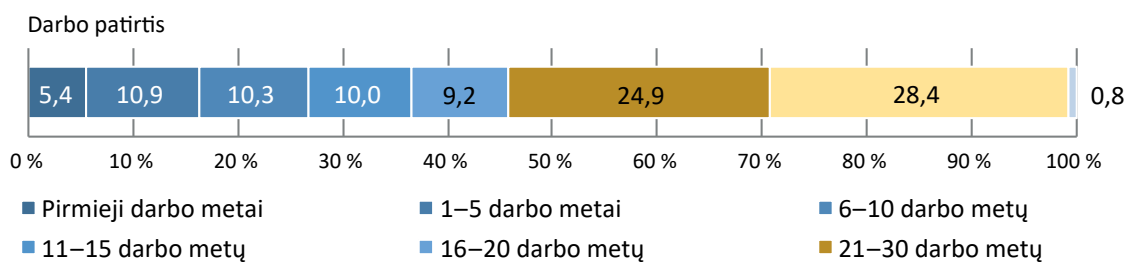

6 pav. Darbuotoju pasiskirstymas pagal darbo patirti 
Amžius. Vidutinis dalyvavusių tyrime darbuotoju amžius - 50,1 metų. Didžiausią dali grupëje (173, arba 49,9 proc. visų tyrimo dalyviu) sudaro 51-60 metų amžiaus asmenys, dar penktadali ( 85 , arba 24,5 proc.) 41-50 metų amžiaus atstovai. Darbuotojai iki 40 metų amžiaus sudaro palyginti nedidelę dalị (57, arba 16,5 proc.) visų tyrime dalyvavusių SVB darbuotojų. Grupeje palyginti nedaug darbuotojų, kuriems yra daugiau nei 61 metai (32, arba 9,2 proc.) (7 pav.). Kartu pastebetina, kad darbuotojų pasiskirstymo pagal amžių pogrupių dydžiai beveik atitinka ir vadovų grupès struktūrą.

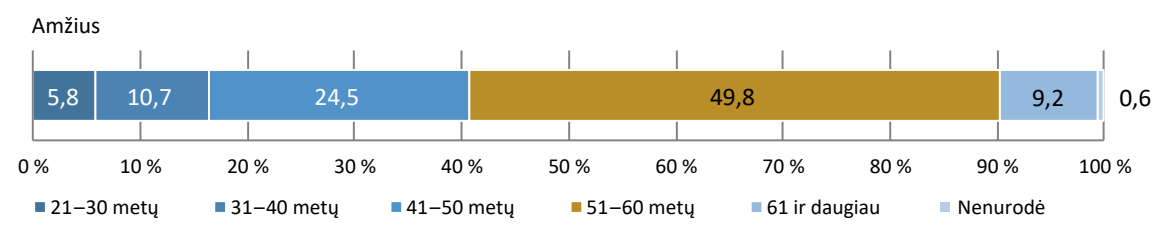

7 pav. Darbuotoju pasiskirstymas pagal amžin

Apibendrindami šiuos duomenis tiriamosios problemos kontekste galime teigti, jog aktualiais tyrimui klausimais nuomonę pareiškusių darbuotoju grupeje yra kiek daugiau (per 60 proc.) skirtingų kvalifikacinių lygių darbuotoju, gerokai anksčiau (iki 1995 m.) igijusių formalujji bibliotekininkystės ir informacijos krypties profesinį išsimokslinimą. Vadovų grupëje tokių informantu yra mažiau (iki 50 proc.), kitą dalị joje sudaro vèliau studijas baigę ir bakalauru, magistru kvalifikacinius lygius igiję asmenys. Abiejų grupių dalyvių vidutinis amžius - per 50 metu, grupèse vyrauja 51-60 metu amžiaus informantai; labiau skiriasi jų darbo patirtis. Vidutinis vadovų darbo stažas - 13,4 metu, o darbuotoju grupejje vidutinè darbo patirtis - 20,8 metų; vadovu grupëje kiek daugiau (53,3 proc.) 1-15 metų darbo patirtị turinčiu asmenų, o darbuotoju grupèje tokią pat dalį (53,5 proc.) sudaro asmenys, kurių darbo stažas bibliotekose daugiau kaip 21 metai.

Taigi galime daryti prielaida, kad ir vienoje, ir kitoje grupeje sistemingu teorinių žinių bei praktinių igūdžių mokslo tiriamosios veiklos 
klausimais studijuodami turëjo galimybę igyti pusè (21, arba 48,8 proc. visų dalyvavusių šioje apklausoje SVB vadovu), t. y. tie vadovai, kurie yra baigę magistro ar bakalauro (universitetines) studiju programas ir trečdalis (117, arba 33,9 proc.) visų dalyvavusių šioje apklausoje SVB darbuotojų. Kita dalis (228, arba 66,1 proc.) darbuotojų ir (22, arba 51,2 proc.) vadovų formaliųu studijų metu turëjo gana ribotas galimybes susipažinti su tiriamosios veiklos organizavimu, jos vykdymu; geriausiu atveju šias kompetencijas galëjo igyti kvalifikacijai tobulinti skirtuose renginiuose ar mokydamiesi savarankiškai.

\section{TYRIMO REZULTATAI}

\subsection{Mokslo tiriamosios veiklos samprata ir jos identifikavimas SVB dokumentuose}

Remdamiesi atlikta SVB veiklą reglamentuojančiu dokumentu tekstu analize, apibendrinę jos rezultatus, galime teigti, jog terminai „mokslas“, „mokslinis“, „moksliniai tyrimai“, „rinkos tyrimai“, „analize““, „vertinimas“ ir kiti su moksliniais, rinkos tyrimais ar informacine analitine veikla susiję terminai SVB veiklos dokumentuose vartojami dažnai. Visi arba kai kurie iš šių terminų irrašyti absoliučios daugumos (59-ių iš 60-ies, arba 98,3 proc. viso SVB tinklo) veiklos dokumentuose.

Tiesa, ir šių terminų taikymo, ir veiklos reglamentavimo bei dokumentavimo praktikos analizè atskleidè, kad SVB veiklos dokumentuose vartojamų terminų variantiškumas didelis, o veiklos reglamentavimo ir dokumentavimo sistemoje daug neapibrèžtumų ir spragų.

Išanalizavus turimus duomenis, SVB veiklą reglamentuojančiuose dokumentuose rastus terminijos vartosenos atvejus galima suskirstyti $\mathfrak{i}$ 3 pagrindines grupes.

Pirmai grupei gali būti priskiriami tokie dokumentuose padaryti įrašai, kai vartojami žodžiai „,mokslas“, „,mokslinis“, „,mokslinis tyrimas“ ir su žodžiu „mokslas“ ir jo vediniais susiję juos papildantys arba aiškinantys žodžių deriniai. 
Galima išskirti du pogrupius. Pirmas - kai šie terminai vartojami SVB veiklai apskritai apibūdinti. Kai kurių SVB veiklos dokumentuose SVB apibūdinama kaip isstaiga, „<...> veikianti informacijos sklaidos, kultūros, mokslo ir švietimo srityse $<\ldots$..> arba teikianti „<...> visuomenès švietimui, moksliniams tyrimams bei asmenybès ugdymui reikalingą informaciją ir paslaugas" (išskirta E. S.). Greičiausiai taip atsitinka, kai tokie apibūdinimai nurašomi iš Lietuvos Respublikos bibliotekų ịstatymo (2 straipsnio 1 punktas), tos jo dalies, kurioje pateiktos pagrindinès isstatymo sąvokos [11], neteikiant reikšmès faktui, jog šiame įstatyme pateiktas bibliotekos apibūdinimas skirtas atskleisti visoms - ne tik viešosioms bibliotekoms būdingiems požymiams. Taip šiuo atveju sukuriamas viešosios bibliotekos diskursas, kad SVB teikia su mokslu (moksliniais tyrimais, studijomis, mokslinių žinių populiarinimu) susijusias paslaugas bibliotekos vartotojams arba pati biblioteka dalyvauja mokslo žinių kūrimo procese, atlieka mokslinius tyrimus ar igyvendina praktinëje institucinëje veikloje mokslinių tyrimų rezultatus.

Antram pogrupiui priskirtini atvejai, kai teiginiais „<...> organizuoti mokslinius tyrimus $\langle\ldots$. “, ,atlikti mokslinius tyrimus ir eksperimentinę (socialinę, kultūrinę plètra) “, „<...> vykdo mokslinius tyrimus <...> " (ǐskkirta E. S.) faktiškai tvirtinama, kad SVB prisiima pareigą organizuoti (inicijuoti, pirkti iš išorès paslaugų tiekëjų, užsakyti ar kartu su kitomis institucijomis arba savarankiškai atlikti) mokslinius tyrimus arba, kitaip tariant, užtikrinti, kad toje bibliotekoje būtų sistemingai ir kryptingai, taikant mokslo priemones ir metodus nagrinëjami tikrovès objektai, o visuomenei pateikiamos jau apibendrintos, išsamiai patikrintos tokių nagrinèjimu išvados. Kai kuriais atvejais deklaruojama veikla „<...> atlikti <...> eksperimentinę (socialinę, kultūrinę) plètrą“”. Tai leidžia manyti, kad kai kuriose SVB įsipareigojama tikslingai veikti diegiant kitose institucijose atliktų mokslinių tyrimų rezultatus. Kitaip tariant, šiuo atveju galima daryti prielaidą, jog dalis bibliotekų sąmoningai pasirenka šią veiklą ir skiria jai svarbios veiklos statusą. Dažniausiai 
šie terminai randami biblioteku veiklos bendruosiuose nuostatuose, rečiausiai - darbuotojų pareiginiuose nuostatuose.

Antrai grupei gali būti priskiriami tie dokumentuose padaryti įrašai, kuriuose pagrindiniai (reikšminiai) žodžiai yra „tirti“, „tyrinèti“, „<...> vykdyti <...> tyrimus“ (skaitymo, rinkodaros, socialinius ir kitokius) ir pan., tačiau kuriuose tokiems tyrimams netaikomas terminas „moksliniai“. Vertinant formaliai, jie gali būti suprantami kaip bet kurios paskirties tyrimai (taip pat ir moksliniai; galima daryti prielaida, jog ir skaitymo, ir socialiniai tyrimai šiame kontekste gali būti atlikti laikantis moksliniams tyrimams keliamų reikalavimu), tačiau dokumentų sudarytojai „grynųjų“ mokslinių tyrimų kategorijai jų nepriskiria. Dokumentų formuluočių ir jų kontekstinès dalies analizé, pavyzdžiui, „[p]astoviai ir sistemingai tiria gyventojų naudojimosi biblioteka ir jos teikiamoms paslaugoms poreikius, tobulina bibliotekos darbą“, „, „..> tiria Bibliotekos vartotojų poreikius“, „<..> atlieka bibliotekos veiklos analizę ir gyventojų poreikių tyrimus, kurių pagrindu planuojama, prognozuojama ir tobulinama jos veikla" ir pan., leidžia teigti, kad dažniausiai teiginiais „tirti“, „tyrinèti“, „tyrimai“ SVB veiklos dokumentuose norima apibūdinti tyrimus, susijusius su rinkodaros, valdymo sprendimų pagrindimu, paslaugų tobulinimu ir pan.

Remdamiesi atliktos analizès duomenimis, turime pastebèti, jog paskutiniais tiriamojo laikotarpio metais $(2015 \mathrm{~m}$.), o ypač dar vèliau (2016 m., 2017 m.) atnaujintu ar redaguotų dokumentų tekstuose vis dažniau vartojami terminai „rinkos tyrimai“ ar „tyrimai rinkodaros tikslais“, kuriais apibrěžiama tiriamosios veiklos kryptis. Dalis biblioteku remdamosi Ekonominès veiklos rūšių klasifikatoriumi (EVRK) ì dokumentus ịrašo veiklos rūš̌̀ „,73.20 Rinkos tyrimai ir viešosios nuomonès apklausa“.

Mokslo tiriamosios veiklos įrašų dokumentuose ir jų konteksto analizè taip pat leidžia daryti prielaidą, jog dažniausiai ši terminija vartojama sąmoningai, siekiant atskirti mokslinius tyrimus kaip specifinę, palyginti sudètingesnę nei rinkos tyrimai veiklos sritị, kuriai reikia specialiu 
tiriamosios veiklos kompetencijų, išsamių šios srities žinių. Galima numanyti, kad veiklą, kuri dokumentuose įvardijama terminais „tyrimai“, „tiriamoji veikla", dokumentų sudarytojai, lygindami juos su moksliniais tyrimais, vertina kaip kiek paprastesnes, su vadybos procesu ir vadybinemis darbuotoju kompetencijomis susijusias veiklas, kurioms atlikti reikia mažesnių tiriamosios veiklos kompetencijų, tiriamojo darbo igūdžiu ir mažesnių laiko sąnaudų.

Šie terminai aptinkami visose analizuotu dokumentu grupèse: ir bendruosiuose nuostatuose, ir struktūrinių padalinių nuostatuose, ir darbuotojų pareiginiuose nuostatuose.

Trečiai grupei priskirtini terminai, nusakantys informacinę analitinę veiklą ir įvardijami žodžiais „analizuoti“ (dokumentu fonda, veikla, neigiamus atsakymus, statistinius duomenis, veiklos pokyčius, technologijas, biblioteku užsakymus, vartotoju struktūra, savo darbq ir pan.), „atlikti <...> analizę" (veiklos, vartotoju poreikiu, skaitymo ir pan.), „analizuoti ir planuoti“, „analizuoti ir prognozuoti“ (skyriaus (ar) filialo veikla, vartotoju vaiku kultūrinius ir informacinius poreikius ir t. t.). Tyrimo duomenys rodo, jog SVB dokumentuose šie terminai kaip savarankiški veiklos identifikatoriai rečiausiai vartojami bendruosiuose veiklos nuostatuose, rečiau - struktūrinių padalinių nuostatuose. Dažniausiai jie randami darbuotojų pareiginiuose nuostatuose, kuriuose paprastai ir yra formuluojami konkretūs veiksmai ir ipareigojimai asmenims, atliekantiems vienokias ar kitokias funkcijas. Šie terminai labai retai vartojami su žodžiais „mokslas“ ar „moksliniai tyrimai“, o daug dažniau siejami su žodžiais „tyrinèti“, „tirti“, ,atlikti tyrimus" ar jų dariniais.

Kaip galime pastebèti analizuodami 6 lenteleje pateiktus duomenis, moksliniams tyrimams SVB veiklos dokumentuose dokumentuoti vartojamos skirtingos sąvokos ir skirtingi veiklos indikatoriai. Veiklos indikatoriams dažniausiai vartojamos sąvokos „dalyvauti“ (20 kartu) ir „organizuoti“ (20 kartu), kiek rečiau - „vykdyti“ ir „atlikti“ (11 kartų) ir ypač retai - „diegti mokslinių tyrimų rezultatus praktikoje“ (1 kartas). Gana 
įvairūs terminai vartojami ir patiems tyrimams apibūdinti: dažniau dokumentuose vartojamas terminas „moksliniai tyrimai“, kai kur - „bendrieji ir specialieji kultūros tyrimai“, „<...> socialiniai ir kiti tyrimai“, pasitaiko „bibliotekų praktikos tyrimai“, „moksliniai tyrimai ir (socialinė, kultūrinè) plètra“, kurie leidžia daryti prielaidą, jog šiuo atveju turimi galvoje profesionaliai atliekami sudetingi tyrimai, kurie paprastai nusakomi terminu „moksliniai tyrimai“ ir priskiriami šiai mokslo tiriamosios veiklos krypčiai.

6 lentelè. Terminija, dažniausiai vartojama moksliniams tyrimams identifikuoti SVB veiklos dokumentuose

\begin{tabular}{|c|c|c|c|}
\hline $\begin{array}{l}\text { Eil. } \\
\text { Nr. }\end{array}$ & $\begin{array}{c}\text { Formuluotès, irrašytos SVB veik- } \\
\text { los dokumentuose* }\end{array}$ & $\begin{array}{c}\text { Pasi- } \\
\text { karto- } \\
\text { jimu } \\
\text { skaičius }\end{array}$ & $\begin{array}{l}\text { Dokumentas, kuriame įrašytas teks- } \\
\text { tas (nurodoma dokumento rūšis: } \\
\text { bendrieji VB nuostatai, CB struktū- } \\
\text { rinio padalinio nuostatai, teritori- } \\
\text { nio padalinio nuostatai ir pan.) }\end{array}$ \\
\hline 1. & $\begin{array}{l}\text { "Dalyvauti moksliniuose tyrimuose } \\
<\ldots>\text { ".. }\end{array}$ & 19 & $\begin{array}{l}\text { VB nuostatai, } C B \text { struktūriniu padali- } \\
\text { niu nuostatai, VB teritoriniu struktüri- } \\
\text { niu padaliniu nuostatai (15) }\end{array}$ \\
\hline 1.1. & $\begin{array}{l}\text { "Dalyvauti ivairiose programose ir } \\
\text { moksliniuose tyrimuose" }\end{array}$ & 1 & $V B$ nuostatai \\
\hline 2. & $\begin{array}{l}\text { "Organizuoti mokslinius tyrimus } \\
\langle\ldots>\text { > }\end{array}$ & 14 & $\begin{array}{l}\text { VB nuostatai, CB struktūriniu pada- } \\
\text { liniu nuostatai, darbuotojo pareiginiai } \\
\text { nuostatai }\end{array}$ \\
\hline 2.1 . & $\begin{array}{l}\text { "Organizuoja bendruosius ir specia- } \\
\text { liuosius kultüros tyrimus" }\end{array}$ & 3 & $V B$ nuostatai \\
\hline 2.2 . & $\begin{array}{l}\text { "<...> pagal galimybes ir poreikius } \\
\text { organizuoti mokslinius tyrimus } \\
<\ldots>\text { ".. }\end{array}$ & 1 & $V B$ nuostatai \\
\hline 2.3. & $\begin{array}{l}\text { „Organizuoti bibliotekos praktikos } \\
\text { tyrimus, diegti moksliniu tyrimu } \\
\text { rezultatus praktikoje“ }\end{array}$ & 1 & VB metodinès veiklos nuostatai \\
\hline 2.4 . & "Organizuoti lokalius tyrimus" & 1 & $V B$ nuostatai \\
\hline 3. & $\begin{array}{l}\text { "Vykdyti rinkodaros, socialinius ir } \\
\text { kitus tyrimus }<\ldots>\text { " }\end{array}$ & 3 & $V B$ nuostatai \\
\hline 3.1 . & $\begin{array}{l}\text { "Vykdo socialinius ir kitus tyrimus } \\
\langle\ldots . .\rangle "\end{array}$ & 4 & $\begin{array}{l}\text { CB struktūriniu padaliniu nuostatai, } \\
\text { darbuotoju pareiginiai nuostatai }\end{array}$ \\
\hline
\end{tabular}




\begin{tabular}{|c|c|c|c|}
\hline $\begin{array}{l}\text { Eil. } \\
\text { Nr. }\end{array}$ & $\begin{array}{c}\text { Formuluotès, irašytos SVB veik- } \\
\text { los dokumentuose }\end{array}$ & $\begin{array}{c}\text { Pasi- } \\
\text { karto- } \\
\text { jimų } \\
\text { skaičius }\end{array}$ & $\begin{array}{l}\text { Dokumentas, kuriame ịrašytas teks- } \\
\text { tas (nurodoma dokumento rūšis: } \\
\text { bendrieji VB nuostatai, CB struktū- } \\
\text { rinio padalinio nuostatai, teritori- } \\
\text { nio padalinio nuostatai ir pan.) }\end{array}$ \\
\hline 3.2 . & $\begin{array}{l}\text { „Atlieka mokslo ir tiriamaji } \\
\text { darba: rengia anketas, vartotojy } \\
\text { apklausas, atlieka tyrimus }<\ldots . .\end{array}$ & 1 & Darbuotojo pareiginiai nuostatai \\
\hline 3.3. & $\begin{array}{l}\text { "Atlikti mokslinius tyrimus ir eks- } \\
\text { perimentine (kultürinę, socialine) } \\
\text { pletra" }\end{array}$ & 1 & $V B$ nuostatai \\
\hline 3.4. & $\begin{array}{l}\text { "Reikalui esant vykdo mokslinius } \\
\text { tyrimus, priklausomai nuo skyriaus } \\
\text { darbo pobūdžio" }\end{array}$ & 1 & CB struktūrinio padalinio nuostatai \\
\hline 3.5 . & $\begin{array}{l}\text { Nurodoma veiklos rüsis: } 72.20 \\
\text { Socialiniu ir humanitariniu mokslu } \\
\text { tyrimai ir taikomoji veikla }\end{array}$ & 1 & $V B$ nuostatai \\
\hline \multirow[t]{2}{*}{4.} & $\begin{array}{l}\text { "Diegti moksliniu tyrimu rezultatus } \\
\text { praktikoje“ }\end{array}$ & 1 & Darbuotojo pareiginiai nuostatai \\
\hline & & 52 & \\
\hline
\end{tabular}

${ }^{*}$ Irašu, rastu dokumentuose, kalba netaisyta.

Sąvokos „tirti“, tyrinèti“, „vykdyti tyrimus“ vartojamos dažniau nei sąvokos „moksliniai tyrimai“ (7 lentelè) ir jų prasmè bei kontekstas paprastai siejami su naudojimosi bibliotekos paslaugomis ir (arba) poreikio jomis naudotis tyrinëjimais. Tyrimo duomenų analizė taip pat leidžia pastebèti, kad dažniausiai veiklos dokumentuose kalbama apie sistemingą (nuolatinę) tokio pobūdžio veiklą. Dažniausiai reglamentuojami poreikių apskritai (kartais apsiribojama bibliotekos vartotoju, kartais ir potencialių vartotojų, t. y. visų teritorijos gyventoju), informacinių poreikių, skaitybos, rečiau visos sistemos, atskirų jos struktūrinių padalinių, informacinių išteklių būklès ar jų panaudojimo tyrinèjimai.

Terminas „informacinè analitinè veikla“ SVB dokumentuose ir veiklos praktikoje vartojamas retai. Dažniau vartojami su šia veikla susiję veiksmo indikatoriai „analizuoti“, „atlikti analizę“. Paprastai viešųuı bibliotekų sektoriuje jie siejami su statistinès ir dalykinès informacijos apie sistemos bibliotekų veiklą rinkimu, išsamiu ir objektyviu jos tyrimu, nagrinëjant bibliotekos veiklos rodiklių dinamiką, struktūrą, jų tarpusavio 
ryšius ir priklausomybę, nustatant veiksnius, lèmusius vienus ar kitus rodiklių pokyčius.

7 lentelè. Terminija, dažniausiai vartojama rinkos tyrimams identiffkuoti SVB veiklos dokumentuose

\begin{tabular}{|c|c|c|c|}
\hline $\begin{array}{l}\text { Eil. } \\
\text { Nr. }\end{array}$ & $\begin{array}{c}\text { Formuluotès, irašytos SVB veik- } \\
\text { los dokumentuose* }\end{array}$ & $\begin{array}{l}\text { Pasi- } \\
\text { karto- } \\
\text { jimuc } \\
\text { skaičius }\end{array}$ & $\begin{array}{l}\text { Dokumentas, kuriame ịrašytas } \\
\text { tekstas (nurodoma dokumento } \\
\text { rūšis: bendrieji VB nuostatai, CB } \\
\text { struktūrinio padalinio nuostatai, } \\
\text { teritorinio padalinio nuostatai ir } \\
\text { pan.) }\end{array}$ \\
\hline 1. & $\begin{array}{l}\text { "Nuolat (arba: pastoviai ir siste- } \\
\text { mingai) tirti gyventoju naudojimąs } \\
\text { biblioteka ir poreikius jos teikia- } \\
\text { moms paslaugoms" }\end{array}$ & 25 & $\begin{array}{l}\text { CB struktūriniu padaliniu nuostatai, } \\
\text { VB nuostatai, darbuotoju pareiginiai } \\
\text { nuostatai }\end{array}$ \\
\hline 1.1. & $\begin{array}{l}\text { "Tiria vartotoju poreikius <...>" } \\
\text { arba „Tiria gyventoju poreikius } \\
<\ldots>\text { ".. }\end{array}$ & 13 & $\begin{array}{l}\text { CB struktūriniu padaliniu nuostatai, } \\
\text { VB nuostatai, darbuotoju pareiginiai } \\
\text { nuostatai }\end{array}$ \\
\hline 1.2. & $\begin{array}{l}\text { "Analizuoti vartotoju poreikius, at- } \\
\text { likti kitus taikomuosius tyrimus" }\end{array}$ & 9 & $\begin{array}{l}\text { CB struktūriniu padaliniu nuostatai, } \\
\text { darbuotojų pareiginiai nuostatai }\end{array}$ \\
\hline 1.3. & „Rengti tyrimus projektams" & 1 & Darbuotojo pareiginiai nuostatai \\
\hline 1.4. & $\begin{array}{l}\text { "Tyrinèti bibliotekos ir filialy ko- } \\
\text { munikacineje erdveje vykstančius } \\
\text { procesus" }\end{array}$ & 1 & CB struktūrinio padalinio nuostatai \\
\hline 2. & $\begin{array}{l}\text { "Organizuoja skaitybos poreikiu, } \\
\text { fondo ir kitus tyrimus" }\end{array}$ & 7 & $\begin{array}{l}\text { CB struktüriniu padaliniu nuostatai, } \\
\text { darbuotojų pareiginiai nuostatai }\end{array}$ \\
\hline 2.1 . & 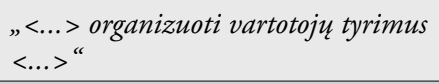 & 1 & $C B$ darbuotoju pareiginiai nuostatai \\
\hline 2.2 . & $\begin{array}{l}\text { "Organizuoja ir atlieka tyrimus, } \\
\text { susijusius su vartotoju poreikiais ir } \\
\text { bibliotekos paslaugu organizavimu, } \\
\text { apibendrina tyrimu medžiagq" }\end{array}$ & 1 & $C B$ darbuotoju pareiginiai nuostatai \\
\hline 3. & $\begin{array}{l}\text { Nurodoma veiklos rüšsis: } 73.20 \text { Rin- } \\
\text { kos tyrimai }\end{array}$ & 13 & $V B$ nuostatai \\
\hline \multicolumn{2}{|c|}{ Iš viso } & 71 & \\
\hline \multicolumn{2}{|c|}{$\begin{array}{l}\text { Irašai teritorinių struktūrinių padali- } \\
\text { nių nuostatuose }\end{array}$} & & \\
\hline 4. & $\begin{array}{l}\text { "Nuolat tirti mikrorajono gyventoju } \\
\text { poreikius bibliotekos paslaugoms" }\end{array}$ & $2 S V B$ & SVB teritoriniu padaliniu nuostatai \\
\hline 4.1. & $\begin{array}{l}\text { "Tiria informacinius poreikius", } \\
\text { "Tiria gyventoju poreikius" }\end{array}$ & $2 S V B$ & SVB teritoriniu padaliniu nuostatai \\
\hline
\end{tabular}




\begin{tabular}{|c|c|c|c|}
\hline $\begin{array}{l}\text { Eil. } \\
\text { Nr. }\end{array}$ & $\begin{array}{c}\text { Formuluotès, irrašytos SVB veik- } \\
\text { los dokumentuose* }\end{array}$ & $\begin{array}{c}\text { Pasi- } \\
\text { karto- } \\
\text { jimų } \\
\text { skaičius }\end{array}$ & $\begin{array}{c}\text { Dokumentas, kuriame įrašytas } \\
\text { tekstas (nurodoma dokumento } \\
\text { rūšis: bendrieji VB nuostatai, CB } \\
\text { struktūrinio padalinio nuostatai, } \\
\text { teritorinio padalinio nuostatai ir } \\
\text { pan.) } \\
\end{array}$ \\
\hline 4.2. & $\begin{array}{l}\text { "Atlieka filialu skaitytoju skaitybos } \\
\text { poreikiu tyrimus" }\end{array}$ & $1 S V B$ & SVB teritoriniu padaliniu nuostatai \\
\hline 4.3. & $\begin{array}{l}\text { "Atlieka seniūnijos gyventoju ir } \\
\text { padalinio skaitytoju skaitybos po- } \\
\text { reikiu tyrimus: rengia ir dalyvauja } \\
\text { rengiant anketas, platina jas <...>" }\end{array}$ & $1 S V B$ & SVB teritoriniu padaliniu nuostatai \\
\hline 4.4 . & $\begin{array}{l}\text { "Dalyvauja tyrimuose, ivairiose } \\
\text { biblioteku vystymo programose" }\end{array}$ & $1 S V B$ & SVB teritoriniu padaliniu nuostatai \\
\hline 4.5 . & $\begin{array}{l}\text { "Dalyvauja atliekant padalinio var- } \\
\text { totoju ir lankytoju poreikiu tyrimus" }\end{array}$ & $1 S V B$ & SVB teritoriniu padaliniu nuostatai \\
\hline \multicolumn{2}{|c|}{ Iš viso } & $8 S V B$ & \\
\hline
\end{tabular}

* Irašu, rastu dokumentuose, kalba netaisyta.

Kaip rodo tyrimo duomenys (8 lentele), veiksmo indikatoriai „analizuoti“ ar „atlikti analizę“ bibliotekų veiklos dokumentuose vartojami ịvairiame kontekste: analizuojama „,_..> bibliotekos veikla“, „bibliotekos paslaugu teikimas visuomenei“, „skyriaus veikla“, „metodinio [ar kitokio] darbo kryptys“, „SVB filialų veikla“, „spaudinių fondo sudètis ir panaudojimas“, „bibliotekos vartotojų ir jų poreikių struktūra“. Kitaip tariant, šiais terminais įvardijamos ir tradicinès funkcijos, kurios paprastai priskiriamos vadovo modelyje išskiriamoms kompetencijoms (problemu supratimas, sprendimų priemimas, vadovavimas, trumpalaikis planavimas, strateginis planavimas, koordinavimas, tikslų nustatymas ir t. t.), ir rinkodaros vadybininko funkcijos, kurių tikslas - užtikrinti patikimą bibliotekos paslaugu ir produktų pateikimą „rinkai“ (arba bibliotekos aptarnaujamai bendruomenei) ir kurios apima rinkos ir paslaugu politikos analizę. 
8 lentelè. Terminija, dažniausiai vartojama informacinei analitinei veiklai identifi-

\section{kuoti SVB veiklos dokumentuose}

\begin{tabular}{|c|c|c|c|}
\hline $\begin{array}{l}\text { Eil. } \\
\text { Nr. }\end{array}$ & $\begin{array}{c}\text { Formuluotès, ịrašytos SVB veiklos } \\
\text { dokumentuose* }\end{array}$ & $\begin{array}{l}\text { Pasikar- } \\
\text { tojimų } \\
\text { skaičius }\end{array}$ & $\begin{array}{l}\text { Dokumentas, kuriame irašytas } \\
\text { tekstas (nurodoma dokumento } \\
\text { rūšis: bendrieji VB nuostatai, CB } \\
\text { struktūrinio padalinio nuostatai, } \\
\text { teritorinio padalinio nuostatai ir } \\
\text { pan.) }\end{array}$ \\
\hline 1. & $\begin{array}{l}\text { Ipareigojimai analizuoti duomenis } \\
\text { apie vartotojus ir bibliotekos pas- } \\
\text { laugu poreikị }\end{array}$ & 81 & $\begin{array}{l}\text { VB nuostatai, struktūriniu padali- } \\
\text { niu nuostatai, darbuotoju pareigi- } \\
\text { niai nuostatai }\end{array}$ \\
\hline \multicolumn{4}{|c|}{ Populiariausi ịrašų pavyzdžiai: } \\
\hline \multicolumn{4}{|c|}{ 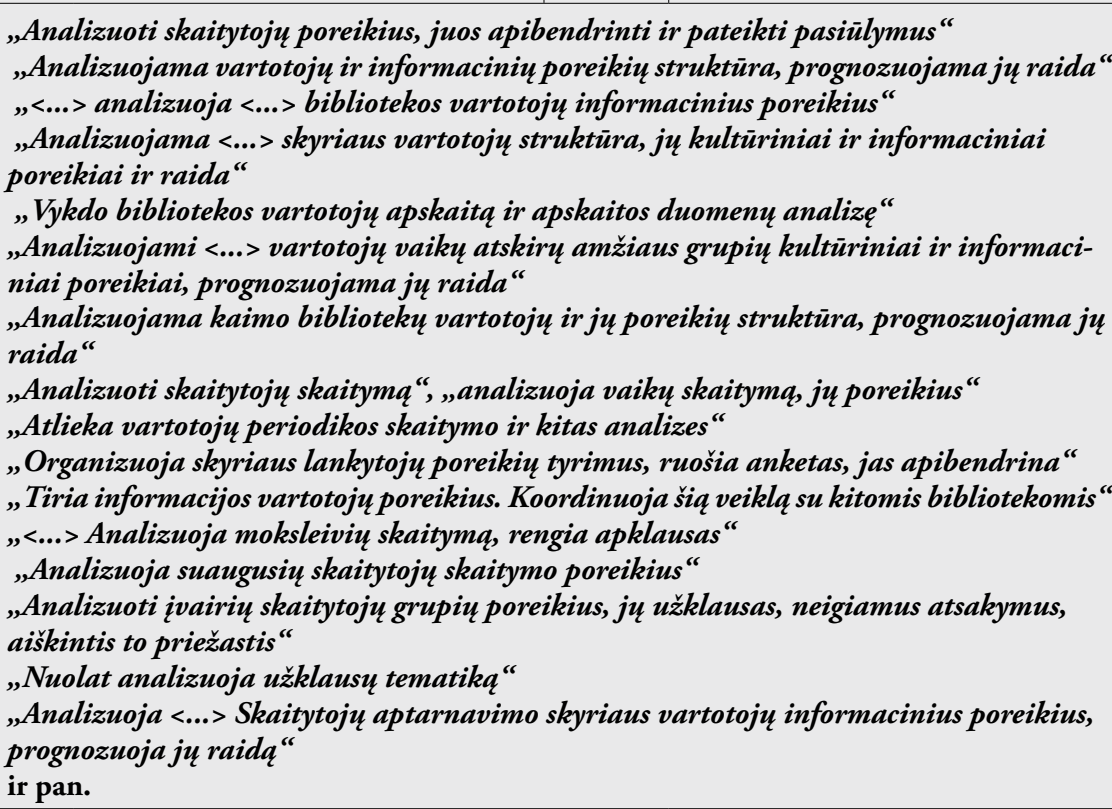 } \\
\hline 2. & & 52 & \\
\hline \multicolumn{4}{|c|}{ Populiariausi įrašų pavyzdžiai: } \\
\hline \multicolumn{4}{|c|}{$\begin{array}{l}\text { „Sistemingai atlieka Bibliotekos veiklos analizę, kurios pagrindu planuojama, progno- } \\
\text { zuojama ir tobulinama veikla" } \\
\text { „Inicijuoja ir koordinuoja Viešosios bibliotekos veiklos analizę <...>“" } \\
\text { "Analizuoti ir planuoti bibliotekinių paslaugu teikima visuomenei“ } \\
\text { „Planuoja, analizuoja, prognozuoja bei koordinuoja Skyriaus veiklą <...>“" }\end{array}$} \\
\hline
\end{tabular}




\begin{tabular}{|c|c|c|c|}
\hline $\begin{array}{l}\text { Eil. } \\
\text { Nr. }\end{array}$ & $\begin{array}{c}\text { Formuluotès, irašytos SVB veiklos } \\
\text { dokumentuose }\end{array}$ & & \\
\hline \multicolumn{4}{|c|}{ 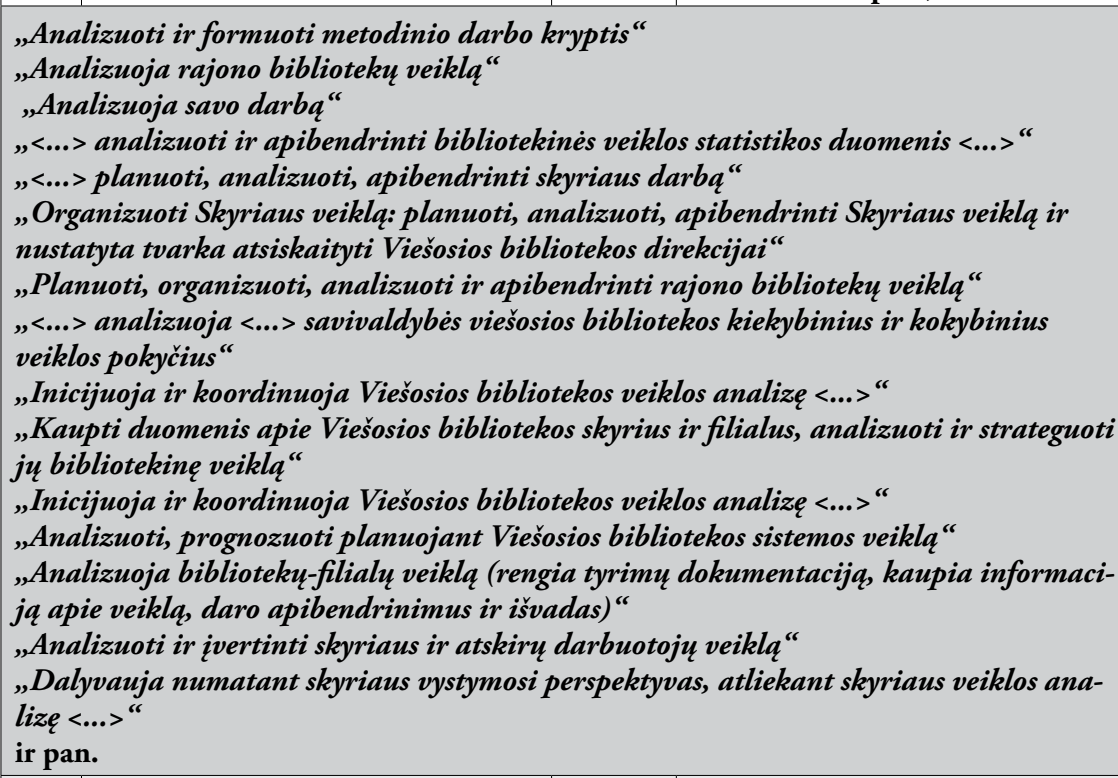 } \\
\hline 3. & & 52 & \\
\hline \multicolumn{4}{|c|}{ Populiariausi įrašų pavyzdžiai: } \\
\hline \multicolumn{4}{|c|}{ 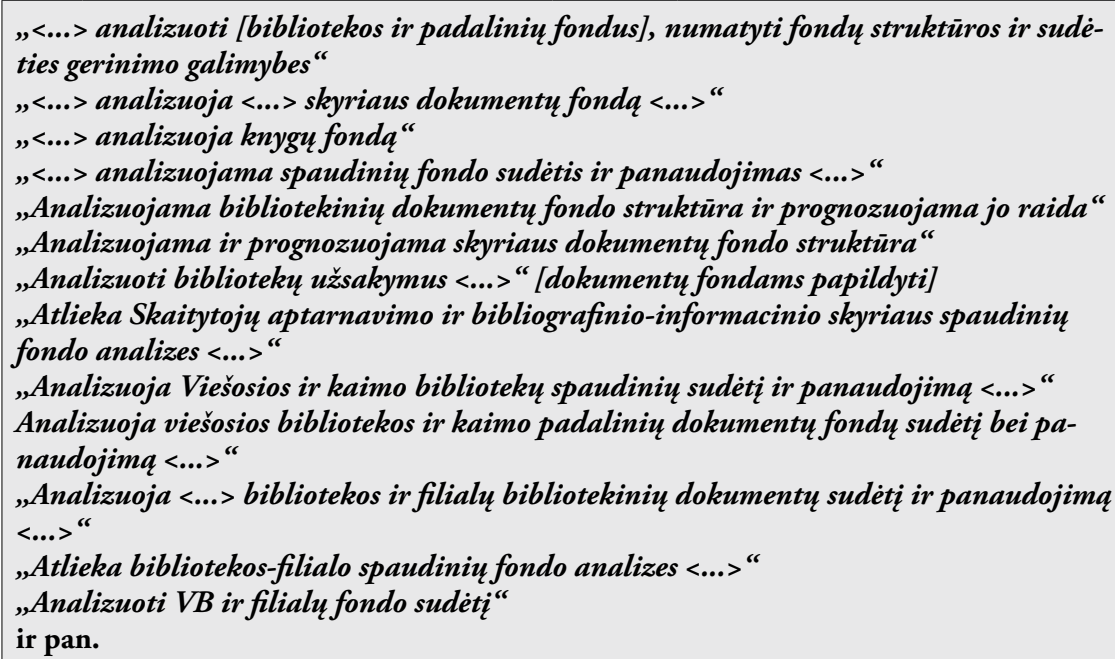 } \\
\hline
\end{tabular}




\begin{tabular}{|c|c|c|c|}
\hline $\begin{array}{l}\text { Eil. } \\
\text { Nr. }\end{array}$ & $\begin{array}{c}\text { Formuluotès, ịrašytos SVB veiklos } \\
\text { dokumentuose* }\end{array}$ & $\begin{array}{l}\text { Pasikar- } \\
\text { tojimuz } \\
\text { skaičius }\end{array}$ & $\begin{array}{c}\text { Dokumentas, kuriame ịrašytas } \\
\text { tekstas (nurodoma dokumento } \\
\text { rūšis: bendrieji VB nuostatai, CB } \\
\text { struktūrinio padalinio nuostatai, } \\
\text { teritorinio padalinio nuostatai ir } \\
\text { pan.) } \\
\end{array}$ \\
\hline 4. & $\begin{array}{l}\text { Ipareigojimai analizuoti kitas (be } \\
\text { vartotojų ir išteklių) bibliotekos } \\
\text { veiklos sritis }\end{array}$ & 2 & $\begin{array}{l}\text { Struktūriniu padaliniu nuostatai, } \\
\text { darbuotoju pareiginiai nuostatai }\end{array}$ \\
\hline \multicolumn{2}{|c|}{ İrašų pavyzdžiai: } & & \\
\hline \multicolumn{4}{|c|}{$\begin{array}{l}\text { „Analizuoti VB technologinius procesus ir teikti pasiūlymus jiems tobulinti“" } \\
\text { „Organizuoti ir koordinuoti bibliotekos rinkodaros ir su rinkodara susijusią mokslo- } \\
\text { tiriamaja veikla" }\end{array}$} \\
\hline & Iš viso ịrašų & 187 & \\
\hline
\end{tabular}

* Irašu, rastu dokumentuose, kalba netaisyta.

VB dokumentų (VB bendrųjų nuostatų ir VB struktūrinių padalinių nuostatu) analizè taip pat atskleidè, kad kuriant mokslo tiriamąją veiklą reglamentuojančius dokumentus (vidutiniškai 5-iais atvejais iš 10-ies) išsaugomas loginis ryšys tarp šiai veiklai apibūdinti visais SVB struktūrų lygmenimis vartojamų sąvokų. Kitaip tariant, jeigu VB nuostatuose tiriamoji veikla apibūdinama vartojant terminą „moksliniai tyrimai“, jis vartojamas ir struktūrinių padalinių nuostatuose; jeigu VB nuostatuose vartojama sąvoka „tirti“, ji vartojama ir struktūrinių padalinių nuostatuose. Tačiau tiek pat atvejų, kai SVB dokumentuose vartojamos skirtingos sąvokos: pavyzdžiui, terminas „moksliniai tyrimai“ vartojamas $V B$ nuostatuose, o struktūrinių padalinių nuostatų teiginiai sudaryti su sąvokomis „tirti“, „tyrimai“; arba VB nuostatuose identifikuojama informacinè analitiné veikla, kuri apibūdinama vartojant sąvoką „analizé“, o struktūrinių teritorinių padalinių nuostatuose atsiranda sąvoka „tyrimai“. Dar reikia pastebèti, kad ir SVB pagrindinèse bibliotekose, ir jų teritorinių padalinių nuostatuose ịrašytoms funkcijoms apibūdinti palyginti dažnai vartojamos dvi sąvokos - „tirti“ ir „analizuoti“. Kai kuriais atvejais šių sąvokų vartojimą galima aiškinti kaip skirtingų funkcijų apibūdinimą, pavyzdžiui, ,analizuojama spaudinių fondo sudètis ir panaudojimas, tiriamos skaitytojų užklausos“ arba „analizuoja savo darbą, tiria vartotoju 
poreikius“. Tačiau vis dèlto daug dažniau dokumentuose pateiktos formuluotės neleidžia nustatyti aiškių ribų tarp skirtingu tiriamosios veiklos rūšių, pavyzdžiui, ,analizuoja ir tiria bibliotekos vartotojų informacinius poreikius“, „nuolat tirti ir analizuoti vartotoju poreikius bei skyriaus fondu komplektavimo principus" ir pan.

Atskirai reikètu kalbèti apie terminiją, kuri vartojama teritorinių struktūrinių padalinių (VB filialu) veiklą reglamentuojančiuose dokumentuose (9 lentelè). Tyrimo duomenys rodo, kad 511 (arba 42,7 proc., $\mathrm{N}=1197$ ) sektoriuje veikiančiu teritorinių struktūrinių padalinių veiklos nuostatuose arba darbuotojų pareiginiuose nuostatuose (arba ir viename, ir kitame tos pačios SVB veiklą reglamentuojančiame dokumente) tiriamoji veikla vienaip ar kitaip įrašyta ị teritorinių struktūrinių padalinių veiklų sąrašus. Dešimtadalyje (149, arba 12,4 proc.) visų teritorinių struktūrinių padalinių ipareigojimai siejami su dalyvavimu mokslo tiriamojoje veikloje (98, arba 8,8 proc. visų teritorinių padaliniu) arba šios veiklos vykdymu (51, arba 4,3 proc. visų teritorinių padaliniu), išsamiau nenurodant veiklų, kurios leistų patikimiau išanalizuoti šių ipareigojimų turinị ir priskirti reglamentuojamą veiklą kuriai nors mokslo tiriamosios veiklos krypčiai.

9 lentelè. Terminija, dažniausiai vartojama mokslo tiriamajai veiklai identiflkuoti SVB teritoriniu struktūriniu padaliniu veiklos dokumentuose

\begin{tabular}{|c|c|c|c|}
\hline $\begin{array}{l}\text { Eil. } \\
\text { Nr. }\end{array}$ & $\begin{array}{c}\text { Formuluotès, ịrašytos } \\
\text { SVB veiklos dokumentuose* }\end{array}$ & 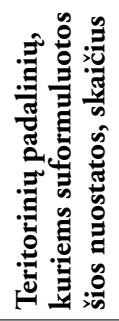 & $\begin{array}{l}\text { Dokumentas, } \\
\text { kuriame ịrašytas } \\
\text { tekstas (nurodoma } \\
\text { dokumento rūšis: } \\
\text { teritorinio pada- } \\
\text { linio nuostatai, } \\
\text { darbuotojo parei- } \\
\text { giniai nuostatai) }\end{array}$ \\
\hline 1. & $\begin{array}{l}\text { "<...> dalyvauja moksliniuose tyrimuose, ivairiose } \\
\text { bibliotekos vystymo programose“ }\end{array}$ & 15 & $\begin{array}{l}\text { Teritoriniu struk- } \\
\text { tūriniu padaliniu } \\
\text { nuostatai }\end{array}$ \\
\hline 2. & $\begin{array}{l}\text { "Dalyvauja tyrimuose, ivairiose bibliotekos vystymo } \\
\text { programose" }\end{array}$ & 28 & $\begin{array}{l}\text { Teritoriniu struk- } \\
\text { tūriniu padaliniu } \\
\text { nuostatai }\end{array}$ \\
\hline
\end{tabular}




\begin{tabular}{|c|c|c|c|}
\hline $\begin{array}{l}\text { Eil. } \\
\text { Nr. }\end{array}$ & $\begin{array}{l}\text { Formuluotès, įrašytos } \\
\text { SVB veiklos dokumentuose }\end{array}$ & 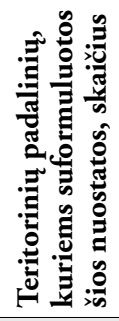 & $\begin{array}{l}\text { Dokumentas, } \\
\text { kuriame ịrašytas } \\
\text { tekstas (nurodoma } \\
\text { dokumento rūšis: } \\
\text { teritorinio pada- } \\
\text { linio nuostatai, } \\
\text { darbuotojo parei- } \\
\text { giniai nuostatai) }\end{array}$ \\
\hline 3. & [Dalyvauja mokslo (tiriamojoje) veikloje] & 55 & Tyrimo dokumentai \\
\hline 4. & [Vykdo mokslo (tiriamaja) veikla] & 33 & Tyrimo dokumentai \\
\hline 5. & "Tirti gyventoju poreikius bibliotekos paslaugoms" & 18 & $\begin{array}{l}\text { Teritoriniu struk- } \\
\text { türiniu padaliniu } \\
\text { nuostatai }\end{array}$ \\
\hline & Ipareigojimai atlikti tiriamaja veikla & 149 & \\
\hline \multicolumn{2}{|r|}{$\begin{array}{c}\text { Dalis (proc.) sektoriaus SVB teritoriniu padaliniu struk- } \\
\text { tūroje }\end{array}$} & 12,4 & \\
\hline 6. & $\begin{array}{l}\text { „Planuoja, analizuoja, apibendrina filialo darba ir } \\
\text { atsiskaito <...> rajono SVB direktoriui, metodininkams } \\
\text { ar administracijos darbuotojams" } \\
\text { „Numato filialo vystymosi perspektyvas, planuoja } \\
\text { filialo veikla, numato filialo tikslus ir uždavinius bei ju } \\
\text { igyvendinimo priemones, nustato poreikius [paslau- } \\
\text { goms], atlieka bibliotekos veiklos analize" }\end{array}$ & 25 & $\begin{array}{l}\text { Teritoriniu struk- } \\
\text { tūriniu padaliniu } \\
\text { nuostatai, } \\
\text { darbuotoju pareigi- } \\
\text { niai nuostatai }\end{array}$ \\
\hline 7. & $\begin{array}{l}\text { "Atlieka seniūnijos gyventoju ir padalinio skaitytoju } \\
\text { skaitybos poreikiu tyrimus: rengia ir dalyvauja } \\
\text { rengiant anketas bei platina jas, atlieka apklausas, ana- } \\
\text { lizuoja, apibendrina duomenis ir pateikia juos viešsios } \\
\text { bibliotekos administracijai“ }\end{array}$ & 24 & $\begin{array}{l}\text { Teritoriniu struk- } \\
\text { tūriniu padaliniu } \\
\text { nuostatai, } \\
\text { darbuotoju pareigi- } \\
\text { niai nuostatai }\end{array}$ \\
\hline 8. & $\begin{array}{l}\text { "Analizuoja savo darba, tiria vartotoju poreikius, } \\
\text { kuriu pagrindu plečia filialo paslaugas" } \\
\text { "Organizuoti, planuoti, analizuoti filialo darbą, teik- } \\
\text { ti planus ir ataskaitas" }\end{array}$ & 20 & $\begin{array}{l}\text { Darbuotoju parei- } \\
\text { giniai nuostatai }\end{array}$ \\
\hline 9. & $\begin{array}{l}\text { "Analizuojama kaimo biblioteku vartotojų ir ju } \\
\text { poreikiu struktüra, prognozuojama ju raida" } \\
\text { "Atlieka mikrorajono gyventoju ir kaimo biblioteku } \\
\text { skaitytoju skaitybos poreikiu tyrimus, apibendrina } \\
\text { duomenis ir pateikia metodininkui" } \\
\text { "Atlieka fondo tyrimus" }\end{array}$ & 23 & $\begin{array}{l}\text { Teritoriniu struk- } \\
\text { tūriniu padalinių } \\
\text { nuostatai, } \\
\text { darbuotoju pareigi- } \\
\text { niai nuostatai }\end{array}$ \\
\hline 10. & $\begin{array}{l}\text { "Nuolat tirti mikrorajono gyventoju poreikius } \\
\text { bibliotekos teikiamoms paslaugoms, tobulinti bibliotekos } \\
\text { darba" } \\
\text { "Atlieka mikrorajono gyventoju ir filialo skaitytoju } \\
\text { skaitybos tyrimus, apibendrina duomenis ir pateikia } \\
\text { juos SVB metodininkui" }\end{array}$ & 10 & $\begin{array}{l}\text { Teritoriniu struk- } \\
\text { tūriniu padaliniu } \\
\text { nuostatai, } \\
\text { darbuotoju pareigi- } \\
\text { niai nuostatai }\end{array}$ \\
\hline
\end{tabular}




\begin{tabular}{|c|c|c|c|}
\hline $\begin{array}{l}\text { Eil. } \\
\text { Nr. }\end{array}$ & $\begin{array}{l}\text { Formuluotès, įrašytos } \\
\text { SVB veiklos dokumentuose }\end{array}$ & 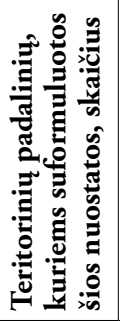 & $\begin{array}{l}\text { Dokumentas, } \\
\text { kuriame ịrašytas } \\
\text { tekstas (nurodoma } \\
\text { dokumento rūšis: } \\
\text { teritorinio pada- } \\
\text { linio nuostatai, } \\
\text { darbuotojo parei- } \\
\text { giniai nuostatai) }\end{array}$ \\
\hline 11. & $\begin{array}{l}\text { "Nuolat tirti gyventoju poreikius bibliotekai ir jos } \\
\text { teikiamoms paslaugoms" } \\
\text { "Atlieka kaimo bibliotekos-filialo skaitytoju skaitymo } \\
\text { poreikiu tyrimus" „Atlieka bibliotekos-filialo spau- } \\
\text { diniu fondo analizes, tyrimus, vykdo vartotoju } \\
\text { poreikiu apklausas" }\end{array}$ & 19 & $\begin{array}{l}\text { Teritoriniu struk- } \\
\text { tūriniu padaliniu } \\
\text { nuostatai, } \\
\text { darbuotoju pareigi- } \\
\text { niai nuostatai }\end{array}$ \\
\hline 12. & $\begin{array}{l}\text { "Vykdo bibliotekos vartotoju apskaita ir apskaitos } \\
\text { duomenu analize“" „Analizuojama bibliotekiniu doku- } \\
\text { mentu fondo struktüra ir prognozuojama jo raida“" } \\
\text { „Analizuojama vartotoju ir informaciniu poreikiu } \\
\text { struktüra, prognozuojama ju raida“" }\end{array}$ & 17 & $\begin{array}{l}\text { Teritoriniu struk- } \\
\text { türiniu padaliniu } \\
\text { nuostatai }\end{array}$ \\
\hline 13. & $\begin{array}{l}\text { "<...> atlieka filialo skaitytoju skaitybos poreikiu } \\
\text { tyrimus, duomenis pateikia viešosios bibliotekos meto- } \\
\text { dininkams" }\end{array}$ & 23 & $\begin{array}{l}\text { Teritoriniu struk- } \\
\text { türiniu padaliniu } \\
\text { nuostatai }\end{array}$ \\
\hline 14. & $\begin{array}{l}\text { "<...> apskaitos dokumentu pildymas, tvarkymas, ana- } \\
\text { lizè, apdorojimas ir pateikimas Bibliotekos administra- } \\
\text { cijai ir specialistui metodinei-edukacinei veiklai" } \\
\text { "vartotoju skaitybos ir paslaugu poreikio tyrimas" } \\
\text { "nuolat tirti gyventoju ir vartotoju poreikius, tobu- } \\
\text { linti Filialo darba“ "sistemingai vykdo Filialo vartotoju } \\
\text { poreikiu tyrima, siekia optimalaus informaciniu porei- } \\
\text { kiu patenkinimo" } \\
\text { "analizuoja Filialo darba, daro išvadas darbui pagerinti" }\end{array}$ & 20 & $\begin{array}{l}\text { Teritoriniu struk- } \\
\text { türiniu padaliniu } \\
\text { nuostatai }\end{array}$ \\
\hline 15. & $\begin{array}{l}\text { "Planuoja, analizuoja, apibendrina bibliotekos } \\
\text { darbą: rengia metinius darbo planus, tekstines ir statis- } \\
\text { tines ataskaitas" }\end{array}$ & 24 & $\begin{array}{l}\text { Darbuotoju parei- } \\
\text { giniai nuostatai }\end{array}$ \\
\hline 16. & $\begin{array}{l}\text { "<..> analizuoja ir teikia pasiūlymus dèl vartotoju } \\
\text { aptarnavimo kokybes ir darbo organizavimo geri- } \\
\text { nimo" }\end{array}$ & 33 & $\begin{array}{l}\text { Darbuotoju parei- } \\
\text { giniai nuostatai }\end{array}$ \\
\hline 17. & $\begin{array}{l}\text { "<...> stebèti ir analizuoti bibliotekos dokumenty } \\
\text { fondo panaudojima" }\end{array}$ & 6 & $\begin{array}{l}\text { Darbuotoju parei- } \\
\text { giniai nuostatai }\end{array}$ \\
\hline 18. & $\begin{array}{l}\text { "Planuoti, organizuoti, analizuoti ir apibendrinti fili- } \\
\text { alo veikla" } \\
\text { "Planuoja, analizuoja, apibendrina jo veikla ir nustaty- } \\
\text { ta tvarka atsiskaito administracijai" } \\
\text { "Prisideda prie flialo fondo komplektavimo: analizuo- } \\
\text { ja neigiamus atsakymus, teikia informacija VB spau- } \\
\text { diniu komplektavimo skyriui apie reikalingus leidinius, } \\
\text { teikia pasiūlymus ir reiškia pastabas del nauju knygu ir } \\
\text { periodiniu leidiniu užsakymo" }\end{array}$ & 38 & $\begin{array}{l}\text { Teritorinio padali- } \\
\text { nio nuostatai, dar- } \\
\text { buotoju pareiginiai } \\
\text { nuostatai }\end{array}$ \\
\hline
\end{tabular}




\begin{tabular}{|c|c|c|c|}
\hline $\begin{array}{l}\text { Eil. } \\
\text { Nr. }\end{array}$ & $\begin{array}{l}\text { Formuluotès, įrašytos } \\
\text { SVB veiklos dokumentuose }\end{array}$ & 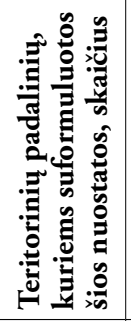 & $\begin{array}{l}\text { Dokumentas, } \\
\text { kuriame ịrašytas } \\
\text { tekstas (nurodoma } \\
\text { dokumento rūšis: } \\
\text { teritorinio pada- } \\
\text { linio nuostatai, } \\
\text { darbuotojo parei- } \\
\text { giniai nuostatai) }\end{array}$ \\
\hline 19. & $\begin{array}{l}\text { "Organizuoti, planuoti, analizuoti ir ivertinti } \\
\text { Viešosios bibliotekos filialo veikla" } \\
\text { „Kasmet rengti Viešosios bibliotekos filialo veiklos } \\
\text { ataskaita ir metini veiklos plana" } \\
\text { „Analizuoti Viešosios bibliotekos lankytoju } \\
\text { poreikius" }\end{array}$ & 22 & $\begin{array}{l}\text { Darbuotoju parei- } \\
\text { giniai nuostatai }\end{array}$ \\
\hline 20. & $\begin{array}{l}\text { „Bibliotekininkas }<\ldots>\text { rengia metines tekstines flialo } \\
\text { ataskaitas. Nuolat analizuoja bibliotekos ir lan- } \\
\text { kytoju reikmes informacijai, registruoja neigiamus } \\
\text { atsakymus <...>" } \\
\text { "Tiria spaudiniu fondo panaudojimo ir skaitymo } \\
\text { büklę, atlieka tyrimus, išvadas pritaiko darbe" }\end{array}$ & 8 & $\begin{array}{l}\text { Darbuotoju parei- } \\
\text { giniai nuostatai }\end{array}$ \\
\hline 21. & $\begin{array}{l}\text { „Kaimo filialo vyr. bibliotekininke organizuoja filialo } \\
\text { veikla: } \\
<\ldots \text { >.. Planuoja, analizuoja, apibendrina jo veikla ir } \\
\text { nustatyta tvarka atsiskaito SVB direkcijai; } \\
<\ldots>\text { Atlieka mikrorajono gyventoju ir filialo } \\
\text { skaitytoju skaitybos poreikiu tyrimus: rengia ir } \\
\text { dalyvauja rengiant anketas bei platina jas, atlieka } \\
\text { apklausas, analizuoja formuliarus ir kitus filialo } \\
\text { dokumentus, apibendrina duomenis ir pateikia juos } \\
\text { SVB metodininkams" }\end{array}$ & 23 & $\begin{array}{l}\text { Darbuotoju parei- } \\
\text { giniai nuostatai }\end{array}$ \\
\hline 22. & 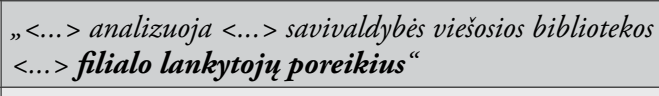 & 20 & $\begin{array}{l}\text { Darbuotoju parei- } \\
\text { giniai nuostatai }\end{array}$ \\
\hline 23. & $\begin{array}{l}\text { "Dalyvauti skaitytoju skaitybos tyrimuose, } \\
\text { dokumentu fondu tyrimuose bei biblioteku vystymo } \\
\text { programose" }\end{array}$ & 7 & $\begin{array}{l}\text { Darbuotoju parei- } \\
\text { giniai nuostatai }\end{array}$ \\
\hline \multicolumn{2}{|r|}{$\begin{array}{l}\text { Ipareigojimai atlikti tiriamaja ir informacinę analitine } \\
\text { veikla }\end{array}$} & 362 & \\
\hline \multicolumn{2}{|r|}{$\begin{array}{l}\text { Dalis (proc.) viso sektoriaus teritorinių padalinių struk- } \\
\text { tūroje }\end{array}$} & 30,2 & \\
\hline \multicolumn{2}{|r|}{$\begin{array}{l}\text { Sektoriuje veikiančių teritorinių struktūrinių padalinių } \\
\text { skaičius }\end{array}$} & $1197^{* *}$ & \\
\hline
\end{tabular}

* Irašų, rastų dokumentuose, kalba netaisyta.

** Duomenis galima rasti http://statistika.libis.lt:7878/pls/apex/f:p=106:18:1134442902438224:: NO::: 
Iš didesnès ịrašų dalies galima spręsti, kad trečdalyje (362-iuose, arba 30,2 proc., $\mathrm{N}=1197)$ visų teritorinių padalinių čia dirbantys specialistai ịpareigojami analizuoti, ịvertinti ir labai dažnai - prognozuoti struktūrinio padalinio veiklą, teikti pasiūlymus pagrindinès SVB specialistams dèl struktūrinio padalinio veiklos pokyčių. Kitaip tariant, teritorinio struktūrinio padalinio funkcijos veiklos dokumentuose siejamos ir su vadybine, ir su tiriamąja veikla, o šio struktūrinio padalinio personalo kompetencijos (dažniausiai jame dirba vienas darbuotojas) - su skirtingų sričių (vadovo, analitiko, rinkodaros vadybininko) kompetencijomis.

Apibendrindami šiuos duomenis, galètume pagristai teigti, jog dokumentuojant mokslo tiriamąją veiklą SVB šią veiklą apibūdinantys terminai vartojami be aiškesnès sistemos, atskiros mokslo tiriamosios veiklos kryptys (moksliniai tyrimai, rinkos tyrimai, informacinè analitinè veikla) tiksliau neišskiriamos ir (ar) neapibrěžiamos.

Iš bendro ir dažniausiai fiksuojamo terminų vartojimo konteksto matyti, kad dažniausiai sektoriaus bibliotekų dokumentuose identifikuojama tiriamoji veikla atitinka informacinių analitinių darbų ir rinkos tyrimų kategoriją. SVB reglamentuojančių dokumentų kūrejai dažniausiai ieško kompromisinių variantu, vartodami universalesnius, mažiau ịpareigojančius terminus „tirti“, „tyrinèti“, „atlikti <...> kitus tyrimus“ ir pan., kurie leidžia laisviau manevruoti pasirenkant veiklos kryptis, ypač kai dokumentuotos nuostatos igyvendinamos praktinejje biblioteku veikloje. Kartu galima atskirti, kad identifikuojant rinkos tyrimų kategoriją veiksmo indikatoriai dažniau apibūdinami sąvokomis „tirti“, „atlikti“, „rengti“ ir pan., rečiau - „organizuoti“", „dalyvauti atliekant“; taigi galime teigti, kad rinkos tyrimai dažniau nei „grynieji“ moksliniai tyrimai siejami su praktinėmis SVB iggyvendinamomis užduotimis ir prisiimamais ịsipareigojimais.

Verta pastebèti, kad kuo vèliau (2014 m., 2015 m., 2016 m.) parengti ir patvirtinti bibliotekos veiklos dokumentai, tuo rečiau juose vartojama sąvoka „moksliniai tyrimai“ (kai kuriose vèlesnèse dokumentų redakcijose jos visiškai išnyksta), ir vis dažniau vartojami terminai, kurie 
semantine prasme ir turiniu labiau siejasi su rinkos tyrimais ir informacine analitine veikla.

\subsection{Mokslo tiriamosios veiklos organizavimas SVB}

\subsubsection{Mokslo tiriamosios veiklos reglamentavimo praktika SVB veiklos dokumentuose}

Sektoriaus mokslo tiriamosios veiklos organizavimo praktikoje galima išskirti dvi pagrindines kryptis. Vienoje iš jų mokslo tiriamosios veiklos funkcijos priskiriamos tik centrinių bibliotekų struktūriniams padaliniams ir juose esančioms pareigybèms. Antrai krypčiai atstovauja tos SVB, kuriose tiriamosios veiklos funkcijos priskiriamos visoms SVB struktūroms: ir centrinès bibliotekos struktūriniams padaliniams bei jos personalui, ir jos teritoriniams struktūriniams padaliniams bei jų personalui. Vertinant kiekybiniu požiūriu ir pirmos, ir antros krypties atstovu SVB sektoriuje yra po lygiai (po $26 \mathrm{SVB}$, kai $\mathrm{N}=52$ ), o atskiruose regionuose pasiskirstymo duomenys kitokie nei vidutiniai šalies rodikliai. Ryškiausiai išsiskiria Kauno regionas, kuriame didžiosios dalies SVB (76,9 proc. viso regioninio tinklo) mokslo tiriamoji veikla priskiriama tik centriniu bibliotekų personalui, o kituose regionuose ị šią veiklą plačiau įtraukiami ir teritoriniai struktūriniai padaliniai. Iš 10 lenteleje pateiktų duomenu galime matyti, kad Panevežio ir Vilniaus regionuose šioje veikloje ịpareigojami dalyvauti daugiau nei 60 proc. teritorinių struktūrinių padaliniu, Klaipėdos regione beveik pusè (45,4 proc.) teritorinių struktūrinių padalinių, kiek mažiau nei pusè (36,4 proc.) teritorinių struktūrinių padalinių ipareigojami veikti mokslo tiriamosios veiklos srityje Šiaulių regione.

Tyrimo duomenys rodo, kad 51-oje SVB (85,0 proc. viso sektoriaus) mokslo tiriamoji veikla reglamentuojama pagrindiniame SVB veiklos dokumente - VB bendruosiuose veiklos nuostatuose; mokslo tiriamąją veiklą ị SVB veiklų sąrašą yra ịrašiusios visos Panevėžio (12) ir Šiaulių (11) regionų SVB, po 84,6 proc. (po 11-a iš 13-os) Kauno ir Vilniaus regiono SVB ir mažiausiai - 45,4 proc., arba 5-ias iš 11-os Klaipèdos regiono SVB. 
Dar 8-iose SVB ši veikla nereglamentuota bendruosiuose nuostatuose, tačiau reglamentuota arba SVB struktūrinių padalinių, arba darbuotojų pareiginiuose nuostatuose. Taigi neatsižvelgiant $\mathfrak{i}$ kai kurių SVB tiriamosios veiklos reglamentavimo schemu spragas galima daryti prielaida, kad mokslo tiriamoji veikla vienaip ar kitaip dokumentuota absoliučioje daugumoje (59-iose, arba 98,3 proc.) sektoriaus biblioteku.

10 lentelè. SVB struktūru ịtrauktis į mokslo tiriamają veikla ir šiu duomenu pasiskirstymas regionuose

\begin{tabular}{|c|c|c|c|c|c|c|c|c|c|}
\hline \multirow[b]{3}{*}{$\begin{array}{l}\text { Eil. } \\
\text { Nr. }\end{array}$} & \multirow[b]{3}{*}{ Regionas } & \multirow[b]{3}{*}{ 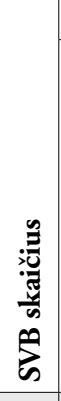 } & \multicolumn{7}{|c|}{ Tiriamoji veikla pavesta } \\
\hline & & & \multirow[b]{2}{*}{ 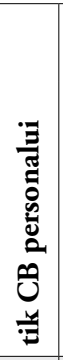 } & \multirow{2}{*}{ 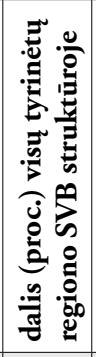 } & \multirow{2}{*}{ 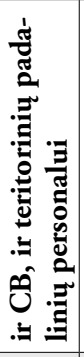 } & \multirow{2}{*}{ 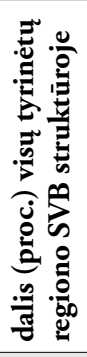 } & \multicolumn{3}{|c|}{$\begin{array}{l}\text { Veiklos pasiskirstymas } \\
\text { teritoriniuose padaliniuose }\end{array}$} \\
\hline & & & & & & & 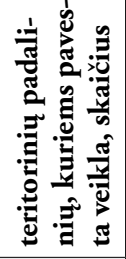 & 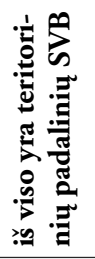 & 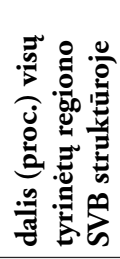 \\
\hline 1. & Kauno & 11 & 10 & 76,9 & 1 & 7,7 & 7 & 278 & 2,5 \\
\hline 2. & Klaipèdos & 9 & 4 & 36,4 & 5 & 45,4 & 99 & 184 & 53,8 \\
\hline 3. & Panevėžio & 12 & 4 & 33,3 & 8 & 66,7 & 193 & 260 & 74,2 \\
\hline 4. & Šiaulių & 9 & 5 & 45,4 & 4 & 36,4 & 72 & 215 & 33,5 \\
\hline 5. & Vilniaus & 11 & 3 & 23,0 & 8 & 61,5 & 140 & 260 & 53,8 \\
\hline \multicolumn{2}{|c|}{ Iš viso regionuose } & 52 & 26 & 50,0 & 26 & 50,0 & 511 & $1197^{*}$ & 42,7 \\
\hline
\end{tabular}

* Duomenis galima rasti http://statistika.libis.lt:7878/pls/apex/f:p=106:111:1063123628041172:1063123628041172

Būtina pastebèti, kad biblioteku veiklos dokumentuose mokslo tiriamoji veikla visomis jos raiškomis nuosekliai ir sistemiškai reglamentuojama tik dalyje SVB: veiklos sistema, kuri sudaro palankią aplinką organizuoti ir vykdyti šį procesą (tiesa, šiuo atveju kalbame apie formalias, dokumentuose įrašytas priemones), sukurta 27-iose SVB, arba mažesnëje (45,0 proc.) sektoriaus dalyje (11 lentele). Didesnès dalies SVB (33-jų arba 55 proc. viso sektoriaus) parengtuose dokumentuose yra ịvairiu neatitikimų ir netikslumų: kai kurių SVB (3,3 proc. viso sektoriaus) veikla reglamentuojama bendruosiuose ir struktūrinių padalinių nuostatuose, tačiau 
nereglamentuota, kurios pareigybės turètų šią veiklą vykdyti; kai kuriose bibliotekose (5-iose SVB, arba 8,3 proc. viso sektoriaus) mokslo tiriamoji veikla reglamentuota SVB bendruosiuose veiklos nuostatuose, bet žemesniuose sistemos lygiuose (struktūrinių padalinių nuostatuose, personalo pareiginiuose nuostatuose) ji nepaskirstyta.

11 lentelè. Mokslo tiriamosios veiklos reglamentavimas SVB veiklos dokumentuose

\begin{tabular}{|c|c|c|c|c|c|c|c|}
\hline \multirow[b]{2}{*}{$\begin{array}{l}\text { Eil. } \\
\text { Nr. }\end{array}$} & \multirow[b]{2}{*}{ Regionas ir SVB } & \multicolumn{5}{|c|}{$\begin{array}{c}\text { Mokslo tiriamoji veikla ịrašyta SVB vietiniuose } \\
\text { teisès aktuose }\end{array}$} & \multirow{2}{*}{ 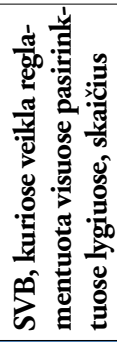 } \\
\hline & & 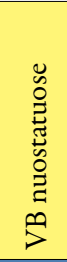 & 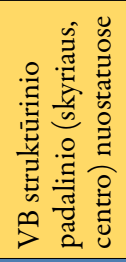 & 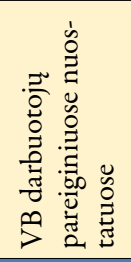 & 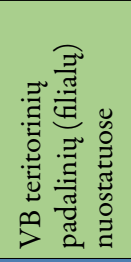 & 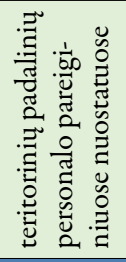 & \\
\hline \multicolumn{2}{|c|}{ KAUNO REGIONAS } & 11 & 7 & 9 & 1 & 1 & 4 \\
\hline 1. & $1 \mathrm{SVB}$ & Yra & 0 & $\begin{array}{l}\text { Trüksta } \\
\text { duomeny }\end{array}$ & 0 & 0 & \\
\hline 2. & $2 S V B$ & 0 & Yra & Yra & 0 & 0 & \\
\hline 3. & $3 \mathrm{SVB}$ & Yra & Yra & Yra & 0 & 0 & 1 \\
\hline 4. & 4SVB & Yra & 0 & Yra & 0 & 0 & \\
\hline 5. & $5 \mathrm{SVB}$ & Yra & Yra & 0 & 0 & 0 & \\
\hline 6. & 6SVB & Yra & Yra & Yra & 0 & 0 & 2 \\
\hline 7. & $7 \mathrm{SVB}$ & Yra & 0 & Yra & 0 & 0 & \\
\hline 8. & $8 \mathrm{SVB}$ & Yra & 0 & Yra & 0 & 0 & \\
\hline 9. & 9SVB & Yra & Yra & Yra & 0 & 0 & 3 \\
\hline 10. & $10 \mathrm{SVB}$ & Yra & 0 & 0 & 0 & 0 & \\
\hline 11. & $11 \mathrm{SVB}$ & Yra & Yra & Yra & 0 & 0 & 4 \\
\hline 12. & $12 \mathrm{SVB}$ & 0 & Yra & Yra & Yra & Yra & \\
\hline 13. & $13 \mathrm{SVB}$ & Yra & 0 & 0 & 0 & 0 & \\
\hline \multicolumn{2}{|c|}{ KLAIPĖDOS REGIONAS } & 6 & 6 & 9 & 3 & 6 & 2 \\
\hline 14. & $1 \mathrm{SVB}$ & Yra & Yra & Yra & 0 & 0 & 5 \\
\hline 15. & $2 S V B$ & 0 & 0 & Yra & 0 & Yra & \\
\hline 16. & 3 SVB & 0 & 0 & 0 & 0 & 0 & 6 \\
\hline 17. & 4SVB & Yra & Yra & Yra & 0 & Yra & \\
\hline 18. & $5 \mathrm{SVB}$ & Yra & 0 & 0 & Yra & 0 & \\
\hline 19. & 6SVB & 0 & 0 & Yra & 0 & Yra & \\
\hline 20. & $7 \mathrm{SVB}$ & Yra & Yra & Yra & 0 & Yra & \\
\hline 21. & $8 \mathrm{SVB}$ & 0 & Yra & Yra & 0 & Yra & \\
\hline 22. & 9SVB & Yra & Yra & Yra & Yra & 0 & \\
\hline 23. & $10 \mathrm{SVB}$ & 0 & Yra & Yra & Yra & 0 & \\
\hline 24. & $11 \mathrm{SVB}$ & Yra & 0 & Yra & 0 & Yra & \\
\hline
\end{tabular}




\begin{tabular}{|c|c|c|c|c|c|c|c|}
\hline \multirow[b]{2}{*}{$\begin{array}{l}\text { Eil. } \\
\text { Nr. }\end{array}$} & \multirow[b]{2}{*}{ Regionas ir SVB } & \multicolumn{5}{|c|}{$\begin{array}{l}\text { Mokslo tiriamoji veikla ịrašyta SVB vietiniuose } \\
\text { teisès aktuose }\end{array}$} & \multirow{2}{*}{ 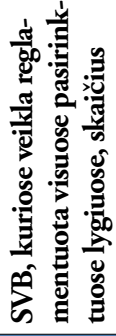 } \\
\hline & & 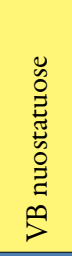 & 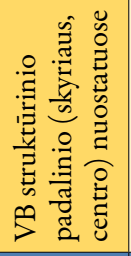 & 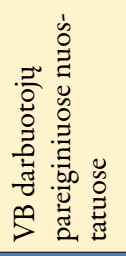 & 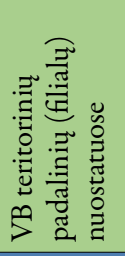 & 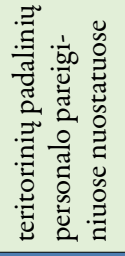 & \\
\hline \multicolumn{2}{|c|}{ PANEVĖŽIO REGIONAS } & 12 & 11 & 12 & 5 & 8 & 9 \\
\hline 25. & $1 \mathrm{SVB}$ & Yra & Yra & Yra & 0 & 0 & 7 \\
\hline 26. & $2 \mathrm{SVB}$ & Yra & Yra & Yra & Yra & Yra & 8 \\
\hline 27. & 3 SVB & Yra & Yra & Yra & 0 & 0 & 9 \\
\hline 28. & $4 \mathrm{SVB}$ & Yra & 0 & Yra & 0 & Yra & \\
\hline 29. & $5 \mathrm{SVB}$ & Yra & Yra & Yra & Yra & Yra & 10 \\
\hline 30. & $6 \mathrm{SVB}$ & Yra & Yra & Yra & Yra & Yra & 11 \\
\hline 31. & $7 \mathrm{SVB}$ & Yra & Yra & Yra & 0 & Yra & \\
\hline 32. & $8 \mathrm{SVB}$ & Yra & Yra & Yra & 0 & Yra & \\
\hline 33. & 9SVB & Yra & Yra & Yra & Yra & Yra & 12 \\
\hline 34. & $10 \mathrm{SVB}$ & Yra & Yra & Yra & 0 & 0 & 13 \\
\hline 35. & $11 \mathrm{SVB}$ & Yra & Yra & Yra & 0 & 0 & 14 \\
\hline 36. & $12 \mathrm{SVB}$ & Yra & Yra & Yra & Yra & Yra & 15 \\
\hline \multicolumn{2}{|c|}{ ŠIAULIŲ REGIONAS } & 11 & 7 & 9 & 3 & 4 & 6 \\
\hline 37. & $1 \mathrm{SVB}$ & Yra & 0 & Yra & 0 & 0 & \\
\hline 38. & $2 \mathrm{SVB}$ & Yra & Yra & Yra & Yra & Yra & 16 \\
\hline 39. & $3 \mathrm{SVB}$ & Yra & Yra & Yra & 0 & Yra & \\
\hline 40. & 4 SVB & Yra & Yra & Yra & Yra & Yra & 17 \\
\hline 41. & $5 \mathrm{SVB}$ & Yra & Yra & Yra & 0 & 0 & 18 \\
\hline 42. & $6 \mathrm{SVB}$ & Yra & 0 & 0 & 0 & 0 & \\
\hline 43. & $7 \mathrm{SVB}$ & Yra & Yra & Yra & 0 & 0 & 19 \\
\hline 44. & $8 \mathrm{SVB}$ & Yra & 0 & Yra & 0 & 0 & \\
\hline 45. & 9SVB & Yra & Yra & Yra & Yra & Yra & 20 \\
\hline 46. & $10 \mathrm{SVB}$ & Yra & 0 & 0 & 0 & 0 & \\
\hline 47. & $11 \mathrm{SVB}$ & Yra & Yra & Yra & 0 & 0 & 21 \\
\hline \multicolumn{2}{|c|}{ VILNIAUS REGIONAS } & 11 & 11 & 11 & 10 & 8 & 6 \\
\hline 48. & $1 \mathrm{SVB}$ & Yra & Yra & Yra & Yra & Yra & 22 \\
\hline 49. & 2 SVB & Yra & Yra & Yra & 0 & 0 & 23 \\
\hline 50. & $3 \mathrm{SVB}$ & 0 & Yra & Yra & Yra & 0 & \\
\hline 51. & 4 SVB & Yra & Yra & Yra & Yra & Yra & 24 \\
\hline 52. & $5 \mathrm{SVB}$ & Yra & Yra & Yra & Yra & Yra & 25 \\
\hline 53. & 6SVB & Yra & 0 & Yra & Yra & Yra & \\
\hline 54. & $7 \mathrm{SVB}$ & Yra & Yra & Yra & 0 & Yra & \\
\hline 55. & 8 SVB & Yra & Yra & Yra & Yra & Yra & 26 \\
\hline 56. & 9 SVB & 0 & Yra & Yra & Yra & Yra & \\
\hline
\end{tabular}




\begin{tabular}{|c|c|c|c|c|c|c|c|}
\hline \multirow[b]{2}{*}{$\begin{array}{l}\text { Eil. } \\
\text { Nr. }\end{array}$} & \multirow[b]{2}{*}{ Regionas ir SVB } & \multicolumn{5}{|c|}{$\begin{array}{c}\text { Mokslo tiriamoji veikla ịrašyta SVB vietiniuose } \\
\text { teisès aktuose }\end{array}$} & \multirow{2}{*}{ 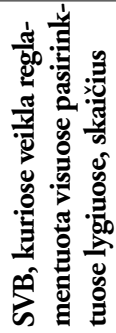 } \\
\hline & & 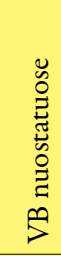 & 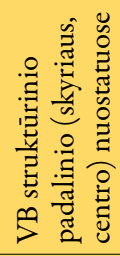 & 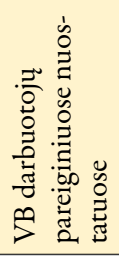 & 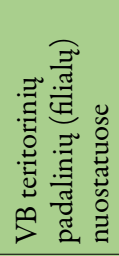 & 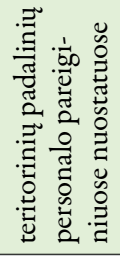 & \\
\hline 57. & $10 \mathrm{SVB}$ & Yra & Yra & 0 & Yra & 0 & \\
\hline 58. & $11 \mathrm{SVB}$ & Yra & Yra & Yra & Yra & 0 & \\
\hline 59. & $12 \mathrm{SVB}$ & Yra & Yra & Yra & Yra & Yra & 27 \\
\hline 60. & $13 \mathrm{SVB}$ & Yra & 0 & 0 & 0 & 0 & \\
\hline & & 51 & 42 & 50 & 22 & 27 & 27 \\
\hline
\end{tabular}

7-iose SVB (11,7 proc. viso sektoriaus) veikla reglamentuojama struktūrinių padalinių nuostatuose ir (ar) personalo pareiginiuose nuostatuose, tačiau nereglamentuota bendrajame SVB veiklos dokumente. Dažniausiai (19-os SVB, arba 33,3 proc. viso sektoriaus) veikla reglamentuojama personalo pareiginiuose nuostatuose, nors tų struktūrinių padalinių yra nedokumentuota.

Palyginę atskirų regionų duomenis galime matyti, kad nuosekliausiai tiriamają veiklą dokumentavusios Panevėžio regiono SVB. Šiame regione du trečdaliai (75,0 proc.) visu regiono SVB yra nuosekliai paskirsčiusios ir dokumentavusios ịpareigojimus šiai veiklai ir centrinès bibliotekos, ir sistemos lygmeniu.

Daugiausia neatitikimų ir fragmentuotų veiklos reglamentavimo įrašų galime aptikti Klaipèdos regiono SVB: čia dažniau nei kituose regionuose veikla nereglamentuota pagrindiniame bibliotekos veiklos dokumente (bendruosiuose veiklos nuostatuose), nors tos SVB darbuotoju pareiginiuose nuostatuose ji įrašyta. Visose 3-jose SVB, kurių teritoriniu padalinių nuostatuose tiriamoji veikla dokumentuota, darbuotojų pareiginiuose nuostatuose ji nereglamentuota.

Tiriamosios veiklos reglamentavimas pareigybiu lygmeniu. Tiriamosios veiklos (visų jos rūšių) ịpareigojimai SVB veiklą reglamentuojančiuose dokumentuose įrašyti 855 SVB darbuotojams. Jie sudaro daugiau 
nei trečiąją dali $(34,6$ proc., $\mathrm{N}=2471)$ visų sektoriuje sukurtų profesionaliųjų bibliotekininku arba operaciniam branduoliui priskiriamo personalo pareigybiu (12 lentelè).

12 lentelè. Pareigybiu itraukties i tiriamaja veikla duomenys regionuose ir ju pasiskirstymas $C B$ ir teritoriniuose padaliniuose

\begin{tabular}{|c|c|c|c|c|c|c|c|c|c|}
\hline \multirow[b]{4}{*}{ Regionas } & \multicolumn{9}{|c|}{ Veikla įrašyta SVB dokumentuose } \\
\hline & \multirow{2}{*}{\multicolumn{3}{|c|}{$\begin{array}{c}\text { personalo skaičius } \\
\text { (CB ir teritoriniuose } \\
\text { padaliniuose, profesio- } \\
\text { naliujų bibliotekininku } \\
\text { pareigybès) }\end{array}$}} & \multicolumn{6}{|c|}{ iš jų } \\
\hline & & & & \multicolumn{3}{|c|}{ CB } & \multicolumn{3}{|c|}{$\begin{array}{l}\text { teritoriniuose } \\
\text { padaliniuose }\end{array}$} \\
\hline & 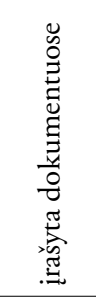 & 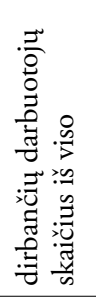 & 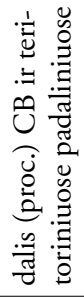 & 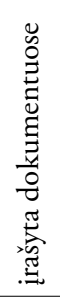 & 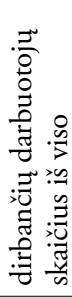 & 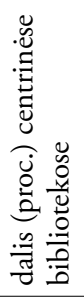 & 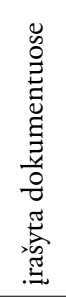 & 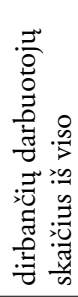 & 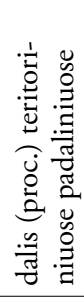 \\
\hline Kauno & 75 & 550 & 13,6 & 68 & 203 & 33,5 & 7 & 347 & 2,0 \\
\hline Klaipèdos & 154 & 413 & 37,3 & 54 & 194 & 27,8 & 100 & 219 & 45,7 \\
\hline Panevèžio & 280 & 517 & 54,2 & 80 & 212 & 37,7 & 200 & 305 & 65,5 \\
\hline Šiaulių & 146 & 424 & 34,4 & 63 & 170 & 37,1 & 83 & 254 & 32,7 \\
\hline Vilniaus & 200 & 567 & 35,3 & 58 & 212 & 27,4 & 142 & 355 & 40,0 \\
\hline Iš viso šalyje & 855 & 2471 & 34,6 & 323 & 991 & 32,6 & 532 & 1480 & 35,9 \\
\hline $\begin{array}{l}\text { Vidutiniškai } \\
\text { 1-oje SVB }\end{array}$ & 14,2 & 41,2 & & 5,4 & 16,5 & & 8,7 & 24,7 & \\
\hline
\end{tabular}

Darbuotojų, kuriems SVB veiklos dokumentuose įrašytas ịpareigojimas veikti mokslo tiriamosios veiklos srityje, skaičius atskiruose regionuose skiriasi (8 pav.): Kauno regione ši veikla reglamentuojama 15,6 proc. visų regiono SVB darbuotojų ( $\mathrm{N}=481)$, o Panevėžio regione - daugiau nei pusei (arba 59,3 proc.) visų regiono viešosiose bibliotekose dirbusių $(\mathrm{N}=472)$ darbuotojų. 


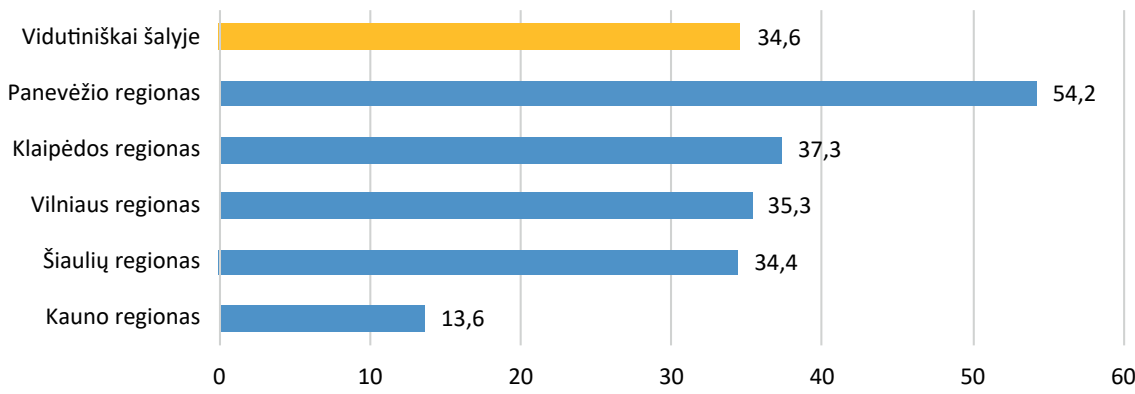

8 pav. Darbuotoju, ịtrauktu i mokslo tiriamaja veikla atskiruose regionuose, dalis (proc.)

Nevienodai šie darbuotojai pasiskirstę ir pačiose SVB sistemose (9 pav.), tačiau bendra visų regionų (išskyrus Kauno) tendencija - kiekybiškai daugiau tiriamojoje veikloje veikiančių darbuotojų sutelkta sistemos teritoriniuose struktūriniuose padaliniuose.

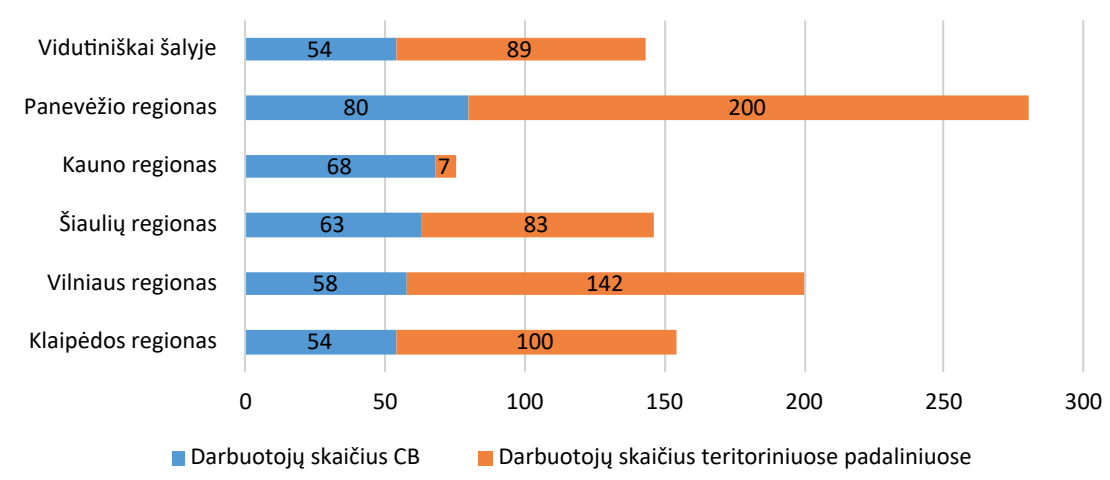

9 pav. Darbuotoju, itranktu i tiriamaja veikla, pasiskirstymas centrinese bibliotekose ir teritoriniuose padaliniuose

Turètume pastebèti, kad praktikoje ị šios veiklos reglamentavimą ir paskirstymą žiūrima gana formaliai. Tai liudija ir SVB darbuotoju apklausos rezultatai: nedaug darbuotojų (17, arba 4,9 proc., $\mathrm{N}=349$ ) teigia, jos jiems ši veikla pavesta, bet jie jos neatlieka; dažniau yra atvirkščiai - beveik penktadalis (82, arba 23,5 proc., $\mathrm{N}=349$ ) apklaustujų teigia, 
kad ju pareiginiuose nuostatuose veikla nereglamentuota, tačiau pavedama ją atlikti. Vienas iš dešimties (37, arba 10,6 proc., $\mathrm{N}=349$ ) apklausoje dalyvavusių darbuotojų nežino savo igaliojimų šioje srityje arba ị šị klausimą neatsakè. Taigi apibendrindami galètume sakyti, kad apie 40 proc. darbuotoju šioje veikloje yra savotiški „,atsarginiai žaidëjai“, kurie arba nepanaudoja turimų kompetencijų, arba darbai pavedami neplaningai, atsitiktinai.

\subsubsection{Mokslo tiriamosios veiklos paskirstymas SVB pagrindinèse bibliotekose (CB)}

Tose centrinėse bibliotekose, kuriose ipareigojimai vienaip ar kitaip veikti tiriamojoje veikloje reglamentuoti ju veiklos dokumentuose (struktūrinių padalinių nuostatuose arba personalo pareiginiuose nuostatuose), ị šią veiklą ịtraukiami visi pagrindiniai funkciniai struktūriniai padaliniai (13 lentelè, 10 pav.). Didžiausias krūvis tenka dviem struktūriniams dariniams: vartotojų aptarnavimo sektoriuje veikiančioms struktūroms ir SVB administravimo ir vadybos funkcijas igyvendinantiems struktūriniams padaliniams ir jų personalui. Vartotojų aptarnavimo funkcijas igyvendinantys $\mathrm{CB}$ struktūriniai padaliniai ipareigoti veikti beveik visose $\mathrm{CB}$, t. y. 49-iose, arba 81,7 proc. visų SVB (N=60), administravimo ir vadybos sektoriuje veikiančios struktūros - 44-iose SVB, arba 73,3 proc. visų SVB ( $\mathrm{N}=60)$. Informacijos išteklių sudarymo ir informacijos paieškų sistemų (IPS) kūrimo sektoriai tiriamosios veiklos srityje ipareigojami veikti 37-iose, arba 61,7 proc. visu SVB (N=60). Bibliografijos ir informacijos srityse veikiantys funkciniai padaliniai ar jų personalas įtraukiamas ị šią veiklą 25-iose $\mathrm{CB}$, arba mažiau nei pusèje (41,7 proc., $\mathrm{N}=60$ ) visu sektoriaus SVB. Atkreiptinas dèmesys, kad SVB metodininku, arba metodinės veiklos funkcijas atliekančių struktūrinių padalinių ịtrauktis ị CB tiriamąją veiklą palyginti maža ir nuolat mažèja; atliekant tyrimą ịpareigojimai veikti mokslo tiriamojoje veikloje formaliai irašyti 23-ju CB, arba kiek daugiau nei trečiojoje dalyje (38,3 proc. visų SVB, $\mathrm{N}=60$ ) visų CB. 
13 lentelè. Mokslo tiriamosios veiklos paskirstymas CB funkciniams struktūriniams padaliniams

\begin{tabular}{|c|c|c|c|c|c|c|c|c|}
\hline & \multirow[b]{2}{*}{ 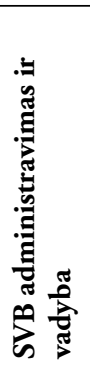 } & \multirow{2}{*}{ 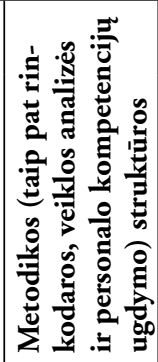 } & \multicolumn{3}{|c|}{$\begin{array}{c}\text { Vartotojų } \\
\text { aptarnavimo, iš jų }\end{array}$} & \multirow{2}{*}{ 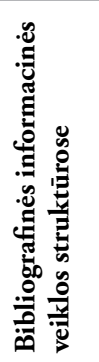 } & \multirow{2}{*}{ 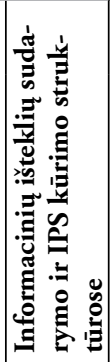 } & \multirow[b]{2}{*}{ 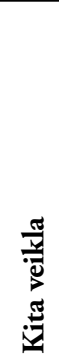 } \\
\hline & & & 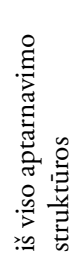 & 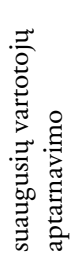 & 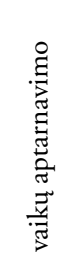 & & & \\
\hline Kauno & 11 & $4^{*}$ & 8 & 8 & 6 & 6 & 6 & 2 \\
\hline Klaipèdos & 7 & $7^{*}$ & 8 & 8 & 7 & 4 & 7 & \\
\hline Panevèžio & 10 & 2 & 12 & 12 & 9 & 4 & 7 & 2 \\
\hline Šiaulių & 7 & 2 & 8 & 8 & 4 & 5 & 5 & \\
\hline Vilniaus & 9 & 8 & 13 & 13 & 12 & 6 & 12 & 1 \\
\hline Iš viso regionuose & 44 & 23 & 49 & 49 & 38 & 25 & 37 & 4 \\
\hline $\begin{array}{l}\text { Dalis (proc.) SVB } \\
\text { struktūrose }(\mathrm{N}=60)\end{array}$ & 73,3 & 38,3 & 81,7 & 81,7 & 63,3 & 41,7 & 61,7 & 6,7 \\
\hline
\end{tabular}

* Metodininku pareigybès Kauno ir Klaipèdos regione nę̨trauktos ị jokị struktürinị padaliní, jos tiesiogiai pavaldžios biblioteku direktoriui.

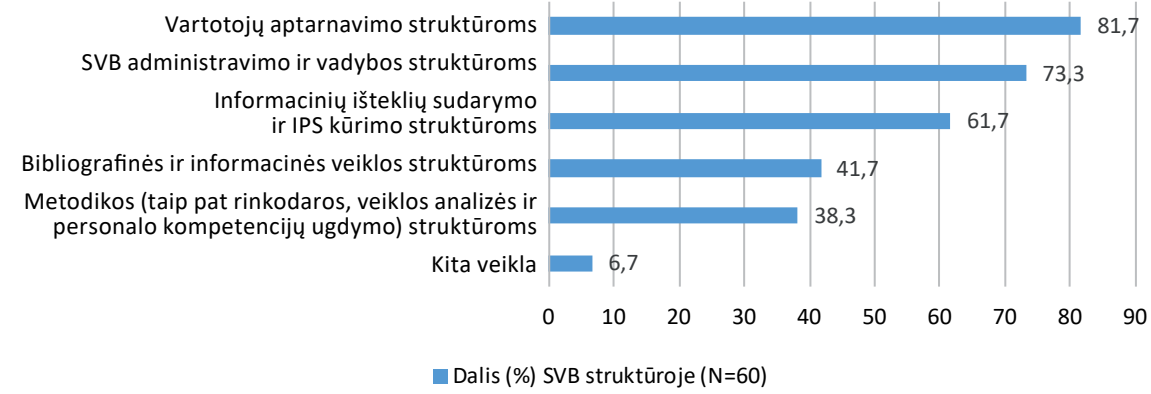

10 pav. Mokslo tiriamosios veiklos paskirstymas $C B$ funkciniams struktüriniams padaliniams

Funkcinių struktūrinių padalinių dalyvavimo tiriamojoje veikloje pasiskirstymo duomenys atskiruose regionuose skiriasi nedaug (11 pav.): Kauno regione dažniau nei kituose regionuose ị mokslo tiriamąją veiklą 
įtraukiamos administravimo ir vadybos struktūros, Panevėžio ir Vilniaus regionuose pirmiau vartotoju aptarnavimo ir antroje vietoje - SVB administravimo ir vadybos struktūros. Vilniaus regione visose SVB ịpareigojamos veikti vartotojų aptarnavimo struktūros, o 9-iose SVB - ir SVB administravimo ir vadybos struktūros. Šiame regione tiriamojoje veikloje dažniau nei kituose regionuose ippareigotos veikti informacinių išteklių sudarymo ir IPS kūrimo struktūros, be to, čia tiriamoji veikla dažniau nei kituose regionuose pavedama ir metodikos sektoriuje veikiančioms CB struktūroms.

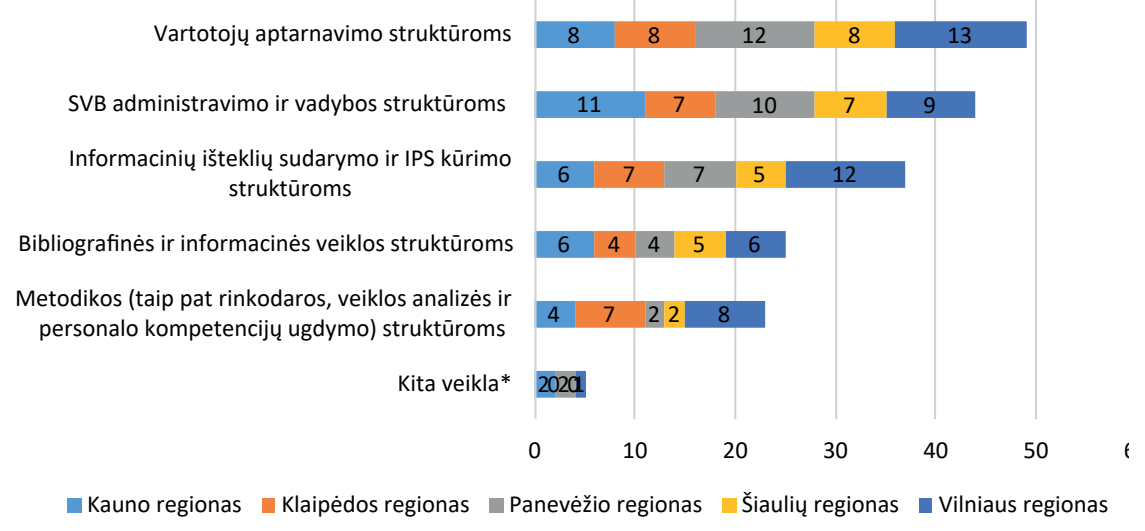

* Kita veikla - né vieno struktūrinio padalinio struktūroje neintegruota kraštotyros ir kompiuterinio tinklo administratoriui pavedama veikla.

11 pav. Mokslo tiriamosios veiklos paskirstymas $C B$ pagal atskirus regionus

Pastebėsime, kad tokie „visuotiniai“ ipareigojimai atlikti mokslo tiriamąją veiklą patvirtina prielaidą, jog ši veikla SVB dažniau suprantama vadybinių funkcijų (,analizuoti savo veiklą") arba rinkos tyrimų kontekste („tirti, analizuoti, vartotoju poreikius"). Metodinès veiklos (tarp ju ir specialistų metodininkų, veikiančių bibliotekos administracijos struktūrose) įtraukties į tiriamąją veiklą duomenis galima laikyti šio sektoriaus silpnëjimo SVB struktūrose požymiu. Nors logiška būtų manyti, kad būtent šiame sektoriuje veikiantis personalas objektyviai (atsižvelgiant $\mathfrak{i}$ šio padalinio funkcinę paskirtį sistemoje, būtinas šioms funkcijoms 
igyvendinti informacinès analitinès veiklos ir tiriamosios veiklos žinias, gebejimus ir igūdžius) turètų būti igijęs daugiausia kompetencijų, tinkamų tiriamajai veiklai vykdyti, realūs bibliotekų sprendimai rodo, kad tiriamoji veikla pašalinama iš metodinès veiklos rūšių sąrašo ir pamažu perduodama naujai kuriamoms organizacijos administravimo struktūroms.

Išsamesnè kiekybinių duomenų analizė rodo, kad SVB CB tiriamoji veikla nustatyta, reglamentuota ir dokumentuota veiklos dokumentuose vidutiniškai 5,5 darbuotojo vienoje $\mathrm{CB}$, arba 323 darbuotojams šioje sektoriaus dalyje, tai sudaro daugiau nei trečdali (32,6 proc.) viso CB personalo. Kiekybiškai daugiausia pareigybių veikia vartotojų aptarnavimo sektoriuje (158 pareigybès, arba 48,9 proc. $(\mathrm{N}=323)$ viso ipareigotu šioje veikloje dalyvauti pareigybių skaičiaus); bibliotekos administravimo sektoriuje ị šią veiklą ittrauktos 77 pareigybès (arba 23,8 proc., $\mathrm{N}=323$ ) (direktoriaus pavaduotojai, direktoriai ir administravimo struktūrų specialistai), bibliografijos ir informacijos sektoriuje - 41 pareigybè (arba 12,7 proc., $\mathrm{N}=323$ ), ištekliu sudarymo sektoriuje - 35 pareigybès (arba 10,8 proc., $\mathrm{N}=323$ ), metodinès veiklos sektoriuje - 10 pareigybiu (arba 3,1 proc., $\mathrm{N}=323$ ). Atskiruose regionuose pareigybiu pasiskirstymas pagal atskirus veiklos sektorius iš esmès atitinka bendrąsias tendencijas (12 pav.): visuose regionuose vyrauja pareigybès, ¿ikurtos vartotoju aptarnavimo sektoriuje, mažiausiai pareigybiu, veikiančių metodinès veiklos ir išteklių sudarymo sektoriuose.

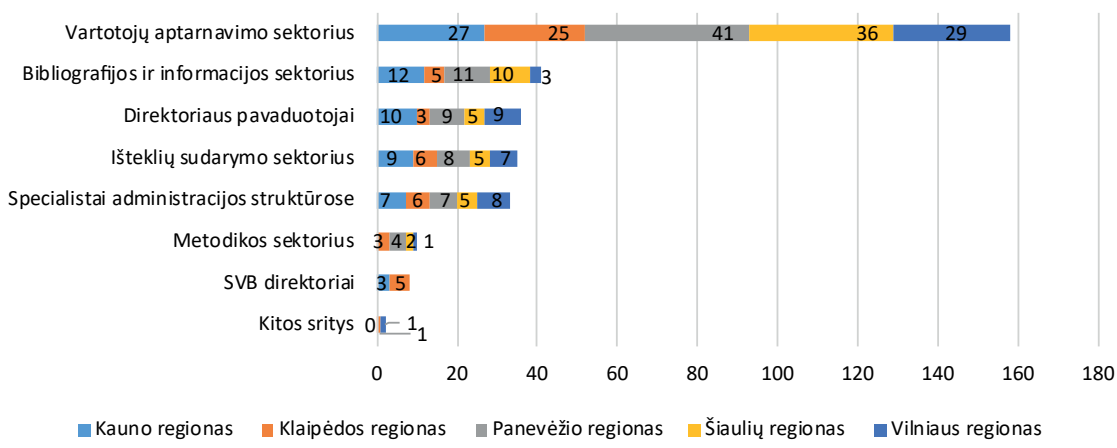

12 pav. Pareigybiu pasiskirstymas $C B$ pagal funkcines sritis ir regionus 
Dokumentuose reglamentuotu mokslo tiriamosios veiklos funkcijų analizė leidžia teigti, jog dažniau CB darbuotojų pareigybèms priskiriama tiriamosios veiklos vykdymo funkcija (13 pav.). Ir nors remiantis dokumentų tekstais sudètinga labai tiksliai nustatyti, kokius konkrečius (mokslinius tyrimus, rinkos tyrimus ar informacinius analitinius) darbus pavedama atlikti atskiroms pareigybèms, gana pagrisstai galima manyti, jog moksliniams tyrimams ir rinkos tyrimams skiriama daugiau dèmesio nei informacinei analitinei veiklai: iš 153 pareigybių, kurioms nustatyta ši funkcija, ipareigojimai tyrinetti skaitymą, vartotoju poreikius, skaitybos poreikius, fondo struktūrą, fondo panaudojimą ir pan. dokumentuose reglamentuoti 94 (arba 61,0 proc., $\mathrm{N}=153$ ) pareigybèms, o ipareigojimai analizuoti duomenis, veiklą, neigiamus atsakymus ir pan. - 59 (arba 39,0 proc., $\mathrm{N}=153$ ) pareigybèms.

Pasyvesnè dalyvavimo funkcija nustatyta $92(28,5$ proc., $\mathrm{N}=323)$ iš visu ị veiklą įtrauktų pareigybiu, organizavimo funkcija - 60 (18,6 proc., $\mathrm{N}=323$ ) iš visų pareigybių, o mokslo tiriamosios veiklos koordinavimo funkcija - tik 6 (1,9 proc., $\mathrm{N}=323)$ iš visų ipareigotų veikti šioje veikloje pareigybių.

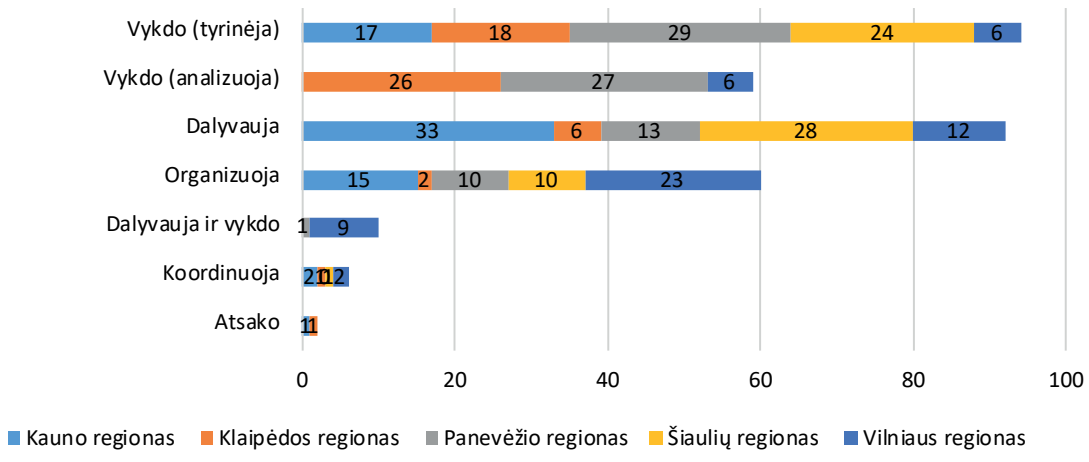

13 pav. Tiriamosios veiklos funkciju pasiskirstymas $C B$ pagal atskirus regionus

Tiriamosios veiklos ipareigojimai atskiruose regionuose reglamentuojami skirtingai. Vilniaus regione dažniau nei kituose regionuose paplitusios sudètingesnès funkcijos, kai atskiroms pareigybėms (dažniausiai 
direktorių pavaduotojams, struktūrinių padalinių vadovams arba tiesiogiai direktoriui pavaldiems specialistams) pavedamos veiklos organizavimo funkcijos kartu su koordinavimo, dalyvavimo ir vykdymo funkcijomis; nors ir šiame regione nemažai pareigybių reglamentuotos dalyvavimo (20,7 proc.) ir vykdymo (20,7 proc.) funkcijos; tai leidžia manyti, jog šiame regione susidarę tiriamosios veiklos organizavimo ir valdymo modeliai gali turèti daugiau planingumo ir sistemingumo požymių.

O Klaipedos, iš dalies ir Panevėžio regionuose daugiau dèmesio skirta tiriamosios veiklos vykdymo funkcijoms: Klaipedos regione vykdymo funkcija pavedama 81,5 proc. visų pareigybių, Panevėžio - 70,0 proc. visu pareigybių. Labiausiai tikètina, kad šiuose regionuose formuojamas (ar stichiškai susiformuoja) toks organizacinis modelis, kai tiriamoji veikla remiasi arba tiesioginiu vykdytojų iniciatyva (ir atsakomybe), o veikla išskaidyta atskiroms pareigybèms ir retai sujungiama ar sutelkiama visos sistemos ar kelių struktūrų lygmeniu.

Kauno ir Šiaulių regionų SVB dokumentuose vyrauja dalyvavimo tiriamojoje veikloje funkcija (48,5 proc. visu pareigybiu Kauno regione ir 44,4 proc. - Šiaulių regione). Ir nors Kauno regione yra kiek daugiau pareigybiu, kurioms priskiriamos veiklos organizavimo funkcijos (22,1 proc.) nei Šiaulių regione (15,9 proc.), visiškai pagrịstai galime teigti, jog šiuose regionuose tiriamosios veiklos politika siejama su išorinių veiklos subjektu iniciatyva ir jų veiksmais organizuojant ir koordinuojant tiriamąją veiklą.

Veiklos organizavimo funkcija sektoriuje gana paplitusi (reglamentuota sektoriuje 60-iai pareigybiu), tačiau toli gražu ne visuose regionuose (mažiausiai organizuojančių tiriamąją veiklą pareigybių yra Klaipėdos (2 pareigybèms), Panevėžio ir Šiaulių regionuose (po 10 pareigybių). Šios veiklos koordinavimo funkcija reglamentuota tik 6 pareigybèms (po 2 pareigybes Kauno ir Vilniaus regionuose ir po 1 pareigybę Klaipedos ir Šiauliu regionuose). Dar 20 pareigybių reglamentuojamos sudètinès funkcijos (organizavimo ir koordinavimo - 12 pareigybiu ir organizavimo, koordinavimo ir vykdymo -8 pareigybėms), tačiau trys ketvirtadaliai tokiu 
pareigybių (15, arba 75,0 proc.) yra viename (Vilniaus) regione. Kartu šie duomenys tik patvirtina, kad vertinant viso sektoriaus mastu veiklos koordinavimas sektoriuje yra menkas, atskirų struktūrinių grandžių veikla susiformavusiuose tiriamosios veiklos organizavimo ir valdymo modeliuose neintegruojama.

\subsubsection{Mokslo tiriamosios veiklos paskirstymas SVB teritori- niams struktūriniams padaliniams}

SVB veiklos dokumentuose tiriamoji funkcija taip pat nustatyta 511 teritorinių padalinių (42,7 proc. viso šių padalinių tinklo, $N=1197)$ ir 532 šiuose struktūriniuose padaliniuose sukurtoms pareigybèms (35,9 proc. visų šiame tinkle veikiančių pareigybių, $\mathrm{N}=1480$ ).

Teritoriniuose padaliniuose veikiančioms pareigybèms reglamentuotos dvi pagrindinès funkcijos: dalyvavimo funkcija (56,0 proc. visu pareigybiu) ir vykdymo funkcija (41,7 proc. visu pareigybiu) (14 lentele, 14 pav.), kuri siejama ir su tiriamosios, ir su informacinès analitinès veiklos kontekstu.

14 lentelè. Tiriamosios veiklos funkciju pasiskirstymas SVB teritoriniuose padaliniuose

\begin{tabular}{|c|c|c|c|c|c|c|c|c|c|c|c|c|c|}
\hline \multirow[b]{2}{*}{$\begin{array}{l}\text { Eil. } \\
\text { Nr. }\end{array}$} & \multirow[b]{2}{*}{$\begin{array}{l}\text { Funkcijos apibū- } \\
\text { dinimas }\end{array}$} & \multirow[b]{2}{*}{ 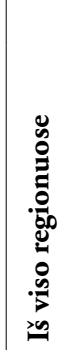 } & \multirow[b]{2}{*}{ 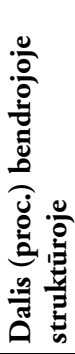 } & \multicolumn{10}{|c|}{ Iš jų } \\
\hline & & & & 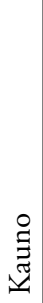 & 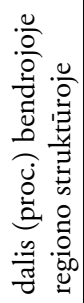 & 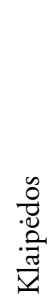 & 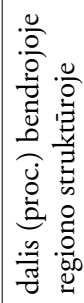 & 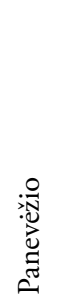 & 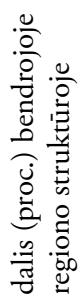 & & 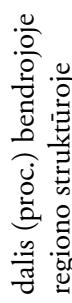 & 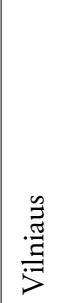 & 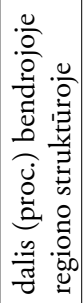 \\
\hline 1. & Dalyv & 298 & 56,0 & 7 & 100,0 & $\mathbf{0}$ & 0,0 & 139 & 69,5 & 47 & 56,6 & 105 & 73,9 \\
\hline 1.1. & Dalyvauja ir vykdo & 66 & 12,4 & 0 & 0,0 & 0 & 0,0 & 0 & 0,0 & 0 & 0,0 & 66 & 46,4 \\
\hline 2. & Vykdo & 222 & 41,7 & $\mathbf{0}$ & 0,0 & 100 & 100,0 & 61 & 30,5 & 36 & 43,4 & 25 & 17,6 \\
\hline 2.1. & & 72 & 13,5 & 0 & 0,0 & 25 & 25,0 & 31 & 15,5 & 16 & 19,3 & 0 & 0,0 \\
\hline 2.2. & Analizuoja & 150 & 28,2 & 0 & 0,0 & 75 & 75,0 & 30 & 15,0 & 20 & 24,1 & 25 & 17,6 \\
\hline 3. & $\begin{array}{l}\text { Organizuoja ir } \\
\text { vykdo }\end{array}$ & 12 & 2,3 & $\mathbf{0}$ & 0,0 & 0 & 0,0 & $\mathbf{0}$ & 0,0 & $\mathbf{0}$ & 0,0 & 12 & 8,4 \\
\hline & so $\mathrm{CB}(1,2,3$ & 532 & 100,0 & 7 & 100,0 & 100 & 100,0 & 200 & 100,0 & 83 & 100,0 & 142 & 100,0 \\
\hline
\end{tabular}


Didesnei veiklų daliai (150 atvejų iš 222 , arba 67,6 proc. visų vykdymo funkcijai priskiriamų veiklu) identifikuoti dažniausiai naudojami veiksmo indikatoriai „analizuoti“, „atlikti analizes“, „vertinti“: pavyzdžiui, , $<\ldots>$ analizuoja, apibendrina bibliotekos darbą $<\ldots .>$ “, , $<\ldots>$ analizuoja skaitytojų sudetį $<\ldots$. “", „<...> atlieka $<\ldots$. > spaudinių fondo analizes $<\ldots$.., , „_..> stebèti ir analizuoti esamo dokumentų fondo panaudojimą $<\ldots$... . Tačiau 72 atvejais iš 222 , arba 32,4 proc. visų vykdymo funkcijai priskiriamų veiklų, teritoriniu padalinių personalo pareigybèse îrašyti ne tik informacinès analitinès, bet ir tiriamosios veiklos ịpareigojimai, pavyzdžiui: „<...> tirti vartotojų skaitymo poreikius“, „<...> atlikti [bibliotekos dokumentu] fondo tyrimus $<\ldots . .>$ “, „<...> vykdyti vartotoju apklausas $<\ldots . .>$ ir t. t. Yra dokumentu, kuriuose teritorinių padalinių darbuotojai ịpareigojami ir analizuoti bibliotekos veiklą, vartotoju poreikius, dokumentu fondą, vartotojų sudètí, neigiamus atsakymus ir pan., ir taip pat „<...> nuolat analizuoti bibliotekos ir lankytoju reikmes informacijai“, „, $[\mathrm{t}] \mathrm{irti}$ spaudinių fondo panaudojimo ir skaitymo būklę, atlikti tyrimus <...> arba „<...> [a] tlikti mikrorajono gyventojų ir filialo skaitytoju skaitybos tyrimus, apibendrinti duomenis ir pateikti juos SVB metodininkui“ ir pan.

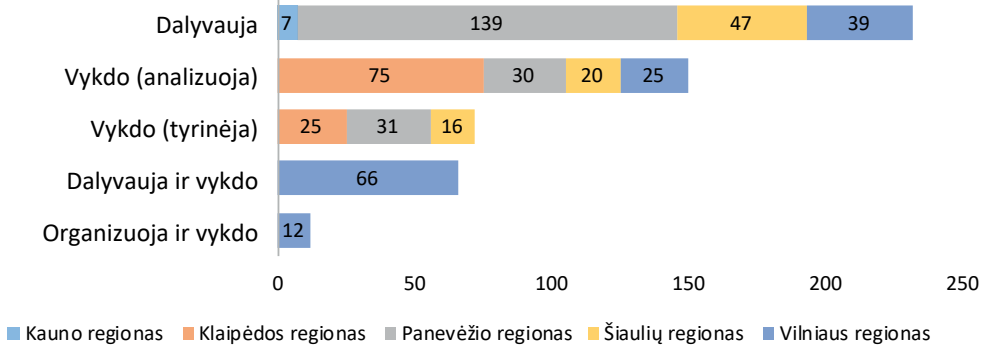

14 pav. Tiriamosios veiklos funkciju pasiskirstymas SVB teritoriniuose padaliniuose

İtraukiant teritoriniu padaliniu personalą ị tiriamąją veiklą regionuose galima išskirti kelis skirtingus požiūrius. Informacinė analitinè šios veiklos kryptis dažniau nei kituose regionuose deklaruojama Klaipėdos regiono teritorinių padalinių veiklą reglamentuojančiuose dokumentuose; 
ipareigojimai atlikti informacinei analitinei veiklai priskiriamus darbus taip pat įrašyti dalies Panevė̌̌io (30), Šiaulių (20) ir Vilniaus (25) regionų teritorinių padalinių veiklos dokumentuose. Šie darbai paprastai siejami su teritorinio struktūrinio padalinio veiklos analize, kuri dažniausiai formuluojama įrašu „[o]rganizuoti, planuoti, analizuoti ir ịvertinti Viešosios bibliotekos filialo veiklą“. Dalyvavimo (kartu su dviguba dalyvavimo ir vykdymo) funkcija, kuri dažniausiai reglamentuota Panevěžio (139 teritoriniams padaliniams priskiriama veikla) ir Vilniaus (105 teritoriniams padaliniams priskiriama veikla) regionų teritorinių padalinių dokumentuose, beveik visada siejama su universaliu terminu „tirti“ „tyrinèti“ ivardijamomis veiklomis. Beveik visais šiais atvejais ir informacinę analitinę veiklą, ir rinkos tyrinëjimus įvardijantys terminai teikiami lygiagrečiai, todèl peršasi išvada, jog SVB veiklos dokumentuose siekiama reglamentuoti ne tik reikalavimus atlikti vadybininko kompetencijai priskiriamas analitines veiklas, tačiau ir įtraukti teritorinių padalinių personalą $\mathfrak{i}$ rinkos tyrinëjimus, kartais pavedant jiems tokius tyrinëjimus organizuoti ir atlikti savarankiškai.

\subsubsection{SVB personalo, kuriam nustatytos mokslo tiriamosios veiklos funkcijos, charakteristika}

Personalo, kuris ịpareigojamas veikti visose ar bent vienoje iš mokslo tiriamosios veiklos sričiu, išsimokslinimo, nuodugnios darbo patirties ir amžiaus analizės duomenys leidžia teigti, jog tiriamosios veiklos funkcija, ịrašant ịpareigojimus ị bibliotekos veiklos dokumentus, dažniausiai paskiriama nekeliant išsimokslinimo ir igyto kvalifikacinio laipsnio reikalavimų: darbuotojai, igiję aukštąji išsimokslinimą, sudaro tik kiek didesnę dalį (412, arba 51,9 proc.) visų šių darbuotojų, palyginti su aukštesnijji išsimokslinimą igijusiais darbuotojais (335, arba 42,2 proc.). Kiek svarbesniu kriterijumi laikoma igyta specialybè - BIK srities išsimokslinimą igijusiems darbuotojams tiriamoji veikla pavedama kiek dažniau, palyginti su kitas specialybes igijusiais asmenimis. Tiesa, aukštąji išsimokslinimą 
igijusių darbuotojų kategorijoje skirtumas tarp skirtingas sritis studijavusių darbuotoju nedidelis $(+1,7$ proc. bibliotekininkystes ir komunikacijos krypties išsimokslinimą igijusių asmenų naudai), tačiau bibliotekininkystės specialybę igiję asmenys aukštesnijji išsimokslinimą igijusių darbuotojų grupejje sudaro gerokai didesnę dalị $(+12,4$ proc.) nei darbuotojai, igiję kitų sričių aukštesnịj išsimokslinimą.

Darbuotoju, igijusių specialųji (BIK krypties) aukštąji išsimokslinimą, grupèje dydžiu ryškiau išsiskiria du darbuotojų pogrupiai: tai asmenys, iki $1995 \mathrm{~m}$. igiję universitetini bibliotekininkystès srities išsimokslinimą (141 darbuotojas, arba 17,8 proc. visų darbuotoju, ịpareigotu veikti tiriamojoje veikloje, $\mathrm{N}=794)$, ir personalas, igijęs aukštesnijji šios srities išsimokslinimą (217, arba 27,3 proc. visų darbuotojų, ịpareigotų veikti tiriamojoje veikloje, $\mathrm{N}=794$ ). Magistro, bakalauro ir profesinio bakalauro kvalifikacinị laipsnị igijęs personalas sudaro nedidelę dalị (72, arba $9,0$ proc.) visų darbuotoju, ipareigotų veikti tiriamojoje veikloje ( $\mathrm{N}=794)$.

15 pav. pateikti duomenys rodo, kad formalujį bibliotekininkystes ir komunikacijos srities pasirengimą igijusių darbuotoju grupëje tiriamojoje veikloje ịpareigojami veikti tiek pat ir aukštąji, ir aukštesnịji šios srities išsimokslinimą igijusių darbuotojų; tiesa, nors ir labai nedidelę kiekybinę persvarą (+4 darbuotojai, arba $+0,5$ proc.) čia turi aukštesnijị išsimokslinimą igijęs personalas.

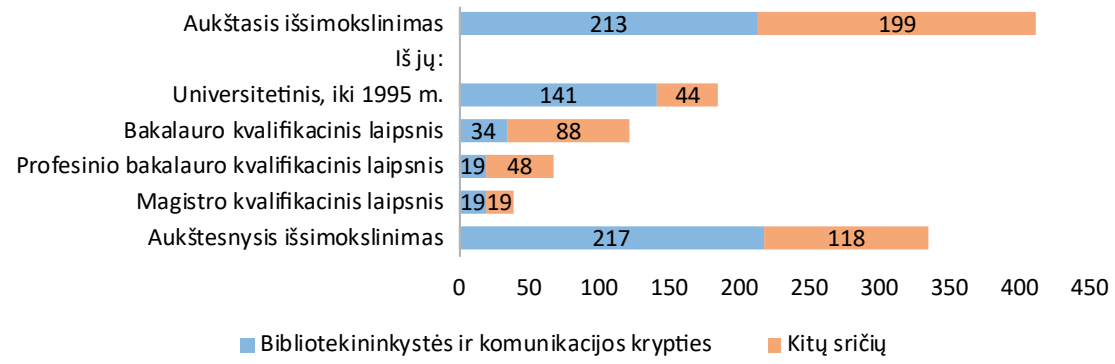

15 pav. Darbuotoju pasiskirstymas pagal igyto formalaus išsimokslinimo sritis 
Aukštajji specialųji (BIK krypties) išsimokslinimą igijusių darbuotojų grupejje kiek daugiau yra universitetinị išsimokslinimą iki 1995 m. (141, arba 66,2 proc., $\mathrm{N}=213$ ) igijusių darbuotojų. Vèliau (arba, kitaip tariant, pagal naujesnes mokymo programas, kurių mokymo planuose daugiau dèmesio skiriama tiriamosios veiklos kompetencijoms igyti) formalųji išsimokslinimą igiję darbuotojai šioje grupëje sudaro palyginti mažesnę dalị (72, arba 33,8 proc., $\mathrm{N}=213$ ). Aukštajji išsimokslinimą igijusių asmenu grupëje vèliau nei $1995 \mathrm{~m}$. studijų programas baigusių specialistu, dalyvaujančių tiriamojoje veikloje, yra perpus mažiau negu specialistu, igijusių kitu, ne bibliotekininkystès ar komunikacijos sričiu bakalauro, magistro ar profesinio bakalauro kvalifikacinius laipsnius (155, arba 72,7 proc., $\mathrm{N}=213)$.

16 pav. parodyta, kokių kitų sričių išsimokslinimą igiję specialistai dažniausiai įtraukiami ị tiriamąją veiklą. Daugumą (53,8 proc. visų specialistų, baigusių ne bibliotekininkystès ir komunikacijų krypties programas) sudaro socialinių mokslų srities kvalifikacijas igiję specialistai, iš kurių daugiausia yra edukologijos mokslų diplomantų (21,0 proc.). Antrai pagal dydi grupei priklauso asmenys, baigę verslo ir viešosios vadybos krypčių programas (17,6 proc.). Specialistai, igiję kultūrinès veiklos vadybos žinių, sudaro nedidelę dalị (5,0 proc.) visų šios grupès narių.

Remdamiesi darbuotoju apklausos duomenimis, galime tvirtinti, jog darbuotojų nuostatos mokslo tiriamosios veiklos klausimais glaudžiai siejasi su ju išsimokslinimu ir igytu kvalifikacijos laipsniu: kuo naujesnes (laiko atžvilgiu) studijų programas yra baigę SVB darbuotojai, tuo pozityviau jie vertina SVB galimybes dalyvauti mokslo tiriamojoje veikloje. Mažiausiai „entuziazmo“ šiuo požiūriu turi aukštesnijji išsimokslinimą igiję darbuotojai; šiam tiriamosios grupès dalyviu pogrupiui būdinga ir tai, kad palyginti daug darbuotojų neigiamas nuostatas išdèstè ir dèl mokslinių tyrimu (35,0 proc.), ir dèl rinkos tyrimu (39,3 proc.), ir dèl informacinès analitinès $(38,9$ proc.) veiklos galimybių SVB. Galetume taip pat teigti, kad pozityvus ar negatyvus požiūris ị mokslo tiriamosios veiklos integravimo ị SVB veiklų 
struktūras nedaug tepriklauso nuo darbuotojų studijuotų mokslų sričių. Ir nors neigiamos nuostatos dèl mokslo tiriamosios veiklos būdingos ir BIK, ir kitas studiju programas baigusiems bibliotekose dirbantiems specialistams, pravartu atkreipti dėmesĭ, jog labiau negatyviai nei pozityviai šiais klausimais nusiteikę BIK studijų programas baigę specialistai.

Apklausos duomenys atskleidè, kad sektoriuje praktinès patirties atliekant mokslinius ir (ar) rinkos tyrimus sukaupta palyginti nedaug. Mažiausiai patirties apklaustų vadovų ir darbuotojų grupèje sukaupta organizuojant mokslinius tyrimus ( 5 atvejai, arba 2,2 proc. visų pasirinkimų, $\mathrm{N}=229$ ); kiek daugiau (11 atvejų, arba 4,8 proc. visų pasirinkimu, $\mathrm{N}=229$ ) organizuojant rinkos tyrimus; savarankiškai mokslinius tyrimus atlikę teigia tik SVB darbuotojai (12 atvejų, arba 5,2 proc. visų pasirinkimų, $\mathrm{N}=229$ ). Vadovų grupeje nèra nė vieno asmens, kuris būtų savarankiškai atlikęs mokslinį tyrimą.

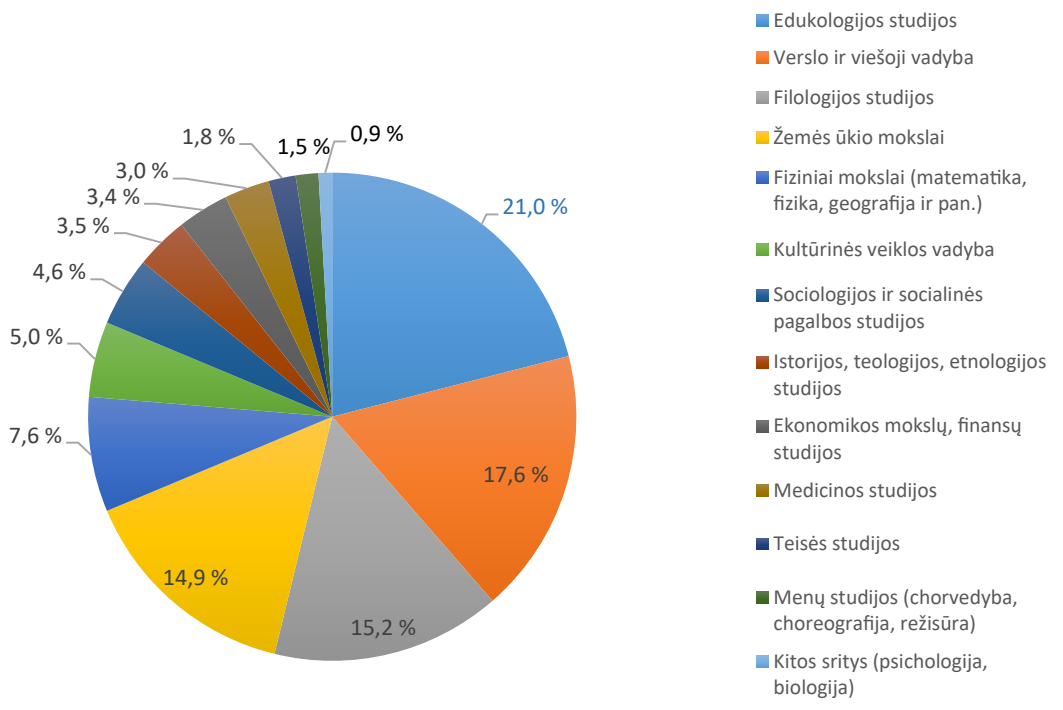

16 pav. Specialistu, igijusiu kitu sričì išsimokslinima, pasiskirstymas pagal mokslo sritis ir kryptis

Patirtis savarankiškai atliekant rinkos tyrimus taip pat nèra reikšminga (16 atvejų, arba 7,0 proc. visų pasirinkimų, $\mathrm{N}=229$ ). Kiek 
reikšmingesnè yra tiek vadovų, tiek darbuotojų dalyvavimo moksliniuose arba rinkos tyrimuose patirtis: ir darbuotojai, ir vadovai kartu yra dažniau dalyvavę rinkos tyrimuose (82 atvejai, arba 35,8 proc. visų pasirinkimu) ir kiek rečiau - moksliniuose tyrimuose (73 atvejai, arba 31,9 proc. visu pasirinkimu), tačiau lyginant abi grupes vadovu patirtis dalyvaujant moksliniuose tyrimuose dažnesnè nei rinkos tyrimuose, o darbuotojai, priešingai, dažniau dalyvauja rinkos tyrimuose nei atliekant mokslinius tyrimus.

Vertindami savo patirti tiriamojo darbo srityje, sektoriaus darbuotojai teigè mažiausiai tokios patirties ir igūdžių sukaupę organizuodami tiriamąją veiklą, kurdami tyrimo strategiją, burdami tyrimo komandas, atsirinkdami tyrimo temas, kurdami tyrimo programas ir jų dokumentus: pasirinkdami tyrimo problemas, temas, nustatydami jų aktualumą ir reikšmingumą, tyrimo tikslus, uždavinius, parengdami tyrimo dokumentus (klausimynus, interviu planus), pasirinkdami mokslinio, rinkos tyrimo ar informacinio analitinio darbo metodiką. Palyginti retai darbuotojai prognozuoja atskirų veiklos sričių plètros perspektyvas, dar rečiau rengia tiriamųjų darbų publikacijas ar organizuoja jų rezultatų sklaidą. Dažniau renkami, analizuojami ir apdorojami statistiniai duomenys metinei veiklos ataskaitai, rengiami atskirų veiklos sričių apibendrinimai, atliekamos tiriamųjų apklausos (išdalijami klausimynai, surenkami apklausų rezultatai).

Apibendrindami šiuos duomenis, turime pastebèti, kad mokslo tiriamoji veikla visame sektoriuje integruota $\mathfrak{i}$ pagrindinio biblioteku personalo (operacinio branduolio, arba profesionaliujų bibliotekininku) pareigybių struktūrą. Sektoriuje nèra nẻ vienos pareigybès, kuriai ši veikla būtų pavesta kaip atskira savarankiška veiklos sritis. Visais atvejais ji pavedama kaip papildoma (šalutinè) veikla šalia kitų funkcinių (valdymo, informacijos išteklių sudarymo, informacinių produktų kūrimo, vartotojų aptarnavimo ir pan.) ipareigojimų. Dèl atskirų mokslo tiriamosios veiklos krypčių, šios veiklos teorinių, metodinių nuostatų neapibrèžtumo ir dalykinių susitarimų visoje korporacijoje stokos SVB mokslo tiriamajai veiklai dokumentuoti ieškoma universaliausių, tinkamų visiems gyvenimo 
atvejams apibūdinimų ir vadybinių sprendimų, dažniausiai fragmentiškai papildant bibliotekininkų kompetencijų sąrašą sisteminio mąstymo, analitinių igūdžių, žinių ir patirties vadovaujant projektams ir (ar) atliekant mokslinius tyrinèjimus reikalavimais. Dar dažniau tokių reikalavimu tiesiog nepaisoma; galima tik spèti, jog viliamasi, kad personalo kompetencijų problema šioje srityje išsispręs kaip nors savaime, galbūt raminamasi tuo, jog didumai profesinių veiklų bibliotekoje ir šiaip jau reikia ir sisteminio mąstymo, ir analitinių igūdžių, o mokslinių tyrinëjimų kompetencijas galima igyti ir kitaip, dažniausiai - savišvietos būdu arba klaidų ir bandymų metodu.

Mokslo tiriamojo darbo organizavimo struktūra turi daug formalioms struktūroms būdingų bruožų. Vyraujantis vyresnis darbuotojų amžius (57,4 proc. vyresni nei 50 metu) yra tam tikras rizikos veiksnys, leidžiantis daryti prielaidą, jog didžiausią dalị sudaro specialistai, kurių aktyvumas ir profesinëje veikloje, ir darbo rinkoje turi ryškią tendenciją mažèti; šis veiksnys ịgyja dar didesnę reikšmę îvertinus tai, kad beveik visai šiai specialistų grupei svarbesnis ne tiek žinių atnaujinimo (perkvalifikavimo) poreikis tiriamosios veiklos srityje, kiek poreikis igyti šios srities bazinių žinių ir kompetencijų.

Tokia padètis turètų būti paaiškinama ir tomis sąlygomis, kuriomis gyvena ir SVB, ir visa bibliotekų bendruomenè. Bibliotekas neišvengiamai veikia demografiniai visuomenès (senëjimo, emigracijos) pokyčiai, mažèjanti profesionaliai pasirengusiu, bibliotekininkystès ir komunikacijos srities išsimokslinimą igijusių diplomantų pasiūla, maži darbuotojų atlyginimai, neleidžiantys konkuruoti su kitais sektoriais dèl geriausių specialistų, nors ir gerëjančio, bet vis dar nepatrauklaus bibliotekų ịvaizdžio padariniai. Šie veiksniai svarbūs ir lemia jaunų darbuotojų stoką, riboja darbuotojų mobilumą ir karjeros galimybes.

Todèl dažnai ieškoma lengviausių sprendimų. Itraukiant ị tiriamąją veiklą biblioteku personalą, reikšmingu kriterijumi laikoma jo funkcinio darbo patirtis ir neišvengiamai su šiuo kriterijumi susijęs ir vyresnis 
darbuotojo amžius. Vis dèlto toks sprendimas patikimas tik iš dalies: patirtis, o juo labiau darbuotojo amžius nèra lemiami veiksniai, leidžiantys ivertinti darbuotojo tinkamumą tiriamajai veiklai. Didelè darbo patirtis gali turèti ir teigiamą, ir neigiamą poveikị, o su žmogaus amžiumi susijusių galimybių vertinimas iš esmès remiasi subjektyvia individo jausena. Esminis neigiamas patirties poveikis yra tas, jog patyrimo pagrindu kuriamas labai individualus žinojimas. Darbo patirtis paprastai teikia duomenis kaip nesutvarkytą, nesusistemintą, o kartais ir neteisingą informaciją, kuri, be to, gali būti ir ịvairiai aiškinama. Dar būtinos kitokios, specifinès žinios, sudarančios galimybę tokius duomenis paversti naudinga informacija. Tik tos specialiosios žinios leistų kiekvienam įvertinti, ką tokie duomenys iš tiesų reiškia, ir - labai svarbu - suprasti, ką su jais daryti.

Kartu dèl reikšmingų veiksnių, tokių kaip vyraujantis prieš 20 metų igytas formalusis profesinis išsimokslinimas, vyresnis darbuotojų amžius, didelè ir vertinga funkciniu atžvilgiu darbo patirtis mokslo tiriamojoje veikloje gali būti pritaikoma nelengvai. Šioje veikloje, kuri visų pirma siejasi su naujovėmis, naujais požiūriais ir kompetencijomis, patirtis dažnai gali labiau trukdyti nei padèti priimti naują informaciją, ypač kai ji palyginti skurdi, dažniausiai apsiribojanti vienos bibliotekos praktika. Ir nors darbui bibliotekose nenustatyta specialių amžiaus ribojimų, remdamiesi Lietuvoje ir kitose šalyse atliktų tyrimų duomenimis, galime tik pastebèti bendriausias su darbuotojo amžiumi susijusias tendencijas: 60-64 metų - tai riba, kai dauguma Lietuvos gyventojų planuoja palikti darbo rinką, o nuo 70 metų mažèja noras dalyvauti bet kokioje veikloje; nuo 65 metų mažèja darbuotojo motyvacija dirbti, menksta ir jo darbo našumas; svarbiausias motyvas (o tai dèl menkų atlyginimų ir pensijų itin aktualu bibliotekose dirbantiems asmenims) likti darbo rinkoje - materialusis veiksnys, ir nors kiti motyvai (bendravimo, priklausomybès bendruomenei, pagarbos ir savigarbos poreikiai) tyrimuose minimi kaip svarbūs veiksniai, šio amžiaus darbuotojų dalyvavimas ir motyvai prisitaikyti prie darbo rinkos ir efektyvaus darbo joje paskatos akivaizdžiai mažèja [49]. 
Sąvokoms „organizuoti“, „koordinuoti“, „dalyvauti“, „vykdyti“ atskirų SVB parengtuose tiriamąją veiklą reglamentuojančiuose dokumentuose gali būti suteikiamos skirtingos reikšmès. Tačiau darydami prielaidą, kad šių sąvokų interpretavimo ribos vis dèlto leidžia įvertinti dokumentuose naudojamus veiksmo indikatorius, galime teigti, jog savivaldybių centrinès bibliotekos palyginti retai matomos kaip tiriamosios veiklos organizatorès net ir neperžengdamos savo sistemos ribų. Centrinių bibliotekų veiklą reglamentuojančiuose dokumentuose dažniausiai nustatoma veiklos vykdymo funkcija, todèl labiausiai tikètina, jog tyrinëjimu iniciatyva ir igyvendinimas dažnai suprantamas ir nustatomas kiekvienai konkrečiai pareigybei kaip privalomas savarankiškas tyrinëjimo darbas, pradedant tyrimo inicijavimu, jo programos ir dokumentu sudarymu ir baigiant tyrimo ataskaitos parengimu. Dažniausiai ši veikla identifikuojama veiksmo indikatoriumi „atlieka“, „nuolat tiria“ ir pan. Taigi galime teigti, jog tiriamoji veikla sistemose matoma kaip išskaidyta veikla, priklausanti daugeliui iniciatyvų, dažniausiai atliekama savarankiškai; pats procesas paliekamas savieigai, beveik nevaldomas ir nekoreguojamas, o (darome prielaida) tokiomis sąlygomis gali būti užtikrintas tik galutinio rezultato įvertinimas.

Dalyvavimo funkcija paprastai suprantama kaip ipareigojimas atlikti tam tikrą dalị tyrimo procedūrų igyvendinant kitų specialistų sudarytas ir koordinuojamas programas, pagal tų asmenu pateiktus veiksmu planus, tvarkaraščius ir suformuluotus reikalavimus duomenų pateikimo, analizės ir rezultatų apibendrinimo kokybei. Nors teoriškai gali būti vadovaujamasi ir kitokiu veiksmu algoritmu, vertinant SVB praktiką, vyrauja modelis, jog pagrindinis tyrimo, kuriame numatyta dalyvavimo funkcija, rengejjas, organizatorius ir (ar) koordinatorius yra kitas asmuo. Todèl, nesant sistemose šios veiklos koordinatoriaus ir organizatoriaus, dalyvavimo funkcija neužtikrina, kad jose būtų inicijuojami, igyvendinami ir atliekami reikšmingesni darbai. Veiklos modelis, kuriame vyrauja dalyvavimo funkcija, gali užtikrinti tik tiek, kad SVB bus igyvendinami tik išorès subjektu 
sumanyti ir organizuoti tiriamosios veiklos projektai ar iniciatyvos. Tokie ipareigojimai veiklos dokumentuose dažniausiai išreiškiami veiksmo indikatoriumi „dalyvauja“ vartojant ịvairias jo formas, pavyzdžiui, „<...> dalyvauja atliekant vartotojų grupių skaitymo, informacinius ir kt. tyrimus", „<..> dalyvauja rengiant anketas ir jas platinant $<\ldots . .>$ “, „dalyvauti įvairiose bibliotekų vystymo programose ir moksliniuose tyrimuose $<\ldots . .>$ " ir pan.

Profesinis pasirengimas, mūsų įsitikinimu, yra svarbus veiksnys, galintis užtikrinti tiriamosios veiklos turinio kokybinius parametrus, gilesnius bibliotekų problemų, reiškinių, procesų, sąvokų bei teorinių žinių taikymo ir jų susiejimo su praktine veikla rezultatus. Tačiau darbuotojų grupeje, kuriai veiklos dokumentuose reglamentuoti tiriamosios veiklos ipareigojimai, yra labai mažai jaunesnių, naujausias specialiąsias mokymo programas studijavusių ir bakalauro (ypač magistro) kvalifikacinius laipsnius igijusių darbuotojų. Vertinant bendriausiu požiūriu abi tiriamojoje veikloje vyraujančios specialujji (bibliotekininkystès, informacijos ir komunikacijos krypties) pasirengimą igijusios darbuotojų grupès susijusios su rimtais rizikos veiksniais: aukštąji išsimokslinimą igijusių darbuotojų grupés nariai yra vyresnio amžiaus, turi palyginti menkas tiriamosios veiklos kompetencijas, igytas studiju metais ir retai atnaujinamas specialiuose kvalifikacijos tobulinimo renginiuose. Tai objektyviai turètu nulemti ir pasyvesni jų santykị su šia veikla. Aukštesniojo specialiojo išsimokslinimo diplomą igiję darbuotojai formaliai, studijų metais tiriamosios veiklos, taip pat ir informacinès analitinės veiklos kompetencijų nėra igiję, todèl dažniausiai yra savamoksliai „tyrëjai“ ir „,analitikai“, žinias igiję klaidų ir bandymu metodu, sẻkmingai arba mažiau sèkmingai jas taikantys praktinëje veikloje.

Darbuotojų, studijavusių kitas mokslų sritis, grupejje palyginti daugiau (+43) naujesnes mokymo programas studijavusių asmenų ir bakalauro, profesinio bakalauro ir magistro kvalifikacinius laipsnius igijusiu darbuotojų (155, arba 19,5 proc. viso ịpareigoto tiriamojoje veikloje dalyvauti personalo, $\mathrm{N}=794)$. Tačiau ir šioje grupeje didžiausią dalị ( 57,4 proc.) 
sudaro asmenys, kurie kaip ir bibliotekininkystès studijas baigę darbuotojai neturi sisteminio pasirengimo tiriamajai veiklai: igiję aukštajj išsimokslinimą iki $1995 \mathrm{~m}$. (12,1 proc.) arba aukštesnịji išsimokslinimą (32,4 proc.), arba darbuotojai, turintys tik bendrąji vidurinị išsimokslinimą (12,9 proc.). Ir nors profesijos žinias bei igūdžius šie darbuotojai paprastai igyja dirbdami darbo vietoje, sisteminių profesinių žinių stoka šios grupès darbuotojų tiriamojoje veikloje gali lemti paviršutiniškumą, seklų turini, menkus rezultatus, o neretai ir apskritai iškreipti ar supaprastinti nagrinëjamų klausimų esmę.

\subsection{SVB sektoriuje atlikti mokslo tiriamieji darbai ir jų kokybès vertinimas}

Remiantis tyrimo duomenimis, 2010-2015 m. SVB buvo atlikta per 180 įvairiausio lygmens tyrinejjimu, t. y. visame sektoriuje vidutiniškai per 30 tyrimu per metus (15 lentele).

Tyrinëjamu laikotarpiu buvo dvi aktyvesnès SVB tiriamosios veiklos lauke veikiančių dalyvių grupès: pačios viešosios bibliotekos (34,2 proc. visų darbų) ir LNB bei apskričių viešosios (regionų) bibliotekos (31,3 proc. visų darbu). Regioniniai metodikos centrai buvo aktyvūs inicijuodami ir organizuodami tiriamąją veiklą savo teritorijoje (regioniniu lygmeniu tiriamuoju laikotarpiu inicijuota 20 tyrimu (arba 11,0 proc. visu šiuo laikotarpiu atliktų tyrimu, $\mathrm{N}=182$ ). Be to, šios institucijos (tai labai svarbu pažymèti) visuomet dalyvavo nacionalinio lygmens tyrinèjimuose kaip LNB partnerès arba savarankiškai atliko tyrimus, kuriuos inicijavo Lietuvos Respublikos kultūros ministerija. Tad galime sakyti, kad daugiau nei pusè (125, arba 68,7 proc.) darbų tiriamuoju laikotarpiu buvo atliekama korporacijos nariu iniciatyva ir pastangomis.

Mokslo ir studijų institucijų inicijuoti ir atlikti tyrimai dažniausiai skirti mokymosi tikslams; 40 atveju iš 47 (arba per 85,1 proc. visu mokslo ir studijų institucijų atliktų darbu) tiriamuoju laikotarpiu atliko studentai, kuriems šių darbų pagrindu buvo suteikti patvirtinimai, kad 
igytas - dažniausiai bakalauro (32, arba 80,0 proc., $\mathrm{N}=40$ ) - kvalifikacinis laipsnis baigus mokymo programą. Palyginti nedaug - kiek daugiau nei dešimtadalis - darbų (7 darbai, arba 14,9 proc., $\mathrm{N}=47$ ) organizuoti ir atlikti mokslo ir studijų institucijų ir SVB partnerystès pagrindu, ju organizatoriai ir atlikèjai - profesionalūs tyrëjai, universitetų ar kolegijų darbuotojai. Magistro kvalifikaciniam laipsniui igyti darbų tiriamuoju laikotarpiu parengta labai mažai (4, arba 2,2 proc. visų darbų, $N=47$ ), ir didesnioji jų dalis parengta konkrečiose bibliotekose dirbančiu magistrantūros studentų (Širvintų, Trakų r. SVB, Vilniaus regionas).

15 lentelè. Tyrimu, atliktu 2010-2015 m. SVB veiklos lauke, iniciatoriai ir (arba) atlikejjai (skaičius ir pasiskirstymas regionais)

\begin{tabular}{|c|c|c|c|c|c|c|c|c|}
\hline \multirow[b]{2}{*}{ Eil. Nr. } & \multirow[b]{2}{*}{$\begin{array}{l}\text { Tyrimų iniciatoriai ir (arba) atli- } \\
\text { kejjai }\end{array}$} & \multirow[b]{2}{*}{ 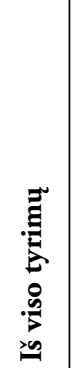 } & \multirow[b]{2}{*}{ 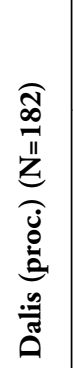 } & \multicolumn{5}{|c|}{$\begin{array}{c}\text { Pasiskirstymas pagal } \\
\text { regionus tyrimuose, } \\
\text { kuriuose dalyvavo SVB }\end{array}$} \\
\hline & & & & 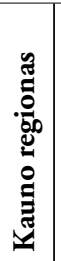 & 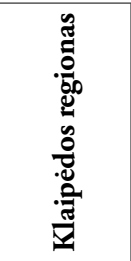 & 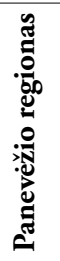 & 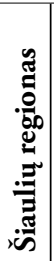 & 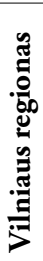 \\
\hline 1. & $\begin{array}{l}\text { Lietuvos Respublikos kultūros } \\
\text { ministerija }\end{array}$ & 6 & 3,3 & 3 & 3 & 3 & 3 & 3 \\
\hline 2. & $\begin{array}{l}\text { Lietuvos nacionalinė Martyno } \\
\text { Mažvydo biblioteka }\end{array}$ & $37^{*}$ & 20,4 & 17 & 17 & 17 & 17 & 17 \\
\hline 3. & Apskričių viešosios bibliotekos (5) & 20 & 10,5 & 9 & 2 & 5 & 1 & 3 \\
\hline 4. & Savivaldybių viešosios bibliotekos & 62 & 34,2 & 16 & $\begin{array}{l}\text { Neteikè } \\
\text { duomenų } \\
\text { (N. d.) }\end{array}$ & 26 & 8 & 12 \\
\hline 5. & Mokslo ir studijų institucijos & 47 & 26,0 & 4 & N. d. & 8 & 26 & 9 \\
\hline 5.1. & Studijų ir mokymosi tikslais, iš jų: & 40 & 22,1 & 2 & N. d. & 8 & 25 & 5 \\
\hline 5.1.1. & $\begin{array}{l}\text { Magistro kvalifikaciniam laipsniui } \\
\text { igyti }\end{array}$ & 4 & 2,2 & 1 & N. d. & 0 & 1 & 2 \\
\hline 5.1.2. & $\begin{array}{l}\text { Bakalauro kvalifikaciniam laipsniui } \\
\text { igyti }\end{array}$ & 32 & 17,7 & 1 & N. d. & 7 & 21 & 3 \\
\hline 5.1.3. & Kursiniai darbai & 3 & 1,7 & 0 & N. d. & 0 & 3 & 0 \\
\hline 5.1 .4 . & Savarankiški darbai & 1 & 0,6 & 0 & N. d. & 1 & 0 & 0 \\
\hline 5.2. & Ne mokymosi ir studijų tikslais & 7 & 3,9 & 2 & N. d. & 0 & 1 & 4 \\
\hline 6. & Savivaldos institucijos & 4 & 2,2 & $\mathbf{0}$ & N. d. & 1 & $\mathbf{0}$ & 3 \\
\hline
\end{tabular}




\begin{tabular}{|c|c|c|c|c|c|c|c|c|}
\hline \multirow[b]{2}{*}{ Eil. Nr. } & \multirow[b]{2}{*}{$\begin{array}{c}\text { Tyrimų iniciatoriai ir (arba) atli- } \\
\text { kèjai }\end{array}$} & \multirow[b]{2}{*}{ 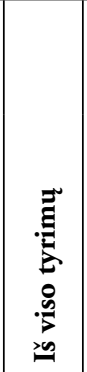 } & \multirow[b]{2}{*}{ 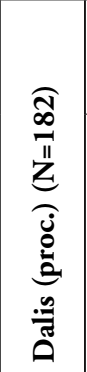 } & \multicolumn{5}{|c|}{$\begin{array}{c}\text { Pasiskirstymas pagal } \\
\text { regionus tyrimuose, } \\
\text { kuriuose dalyvavo SVB }\end{array}$} \\
\hline & & & & 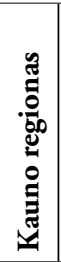 & 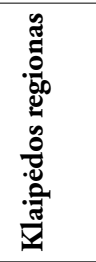 & 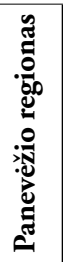 & 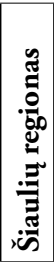 & 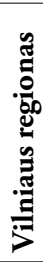 \\
\hline 7. & $\begin{array}{l}\text { Kitos institucijos (leidyklos, Etnines } \\
\text { kultüros globos taryba, rajono śvietimo } \\
\text { centras ir kt.) }\end{array}$ & 6 & 3,3 & $\mathbf{0}$ & N. d. & $\mathbf{0}$ & $\mathbf{0}$ & 6 \\
\hline \multicolumn{2}{|c|}{$\begin{array}{l}\text { Iš viso (be nacionalinio ir regioninio } \\
\text { lygmens instituciju) }\end{array}$} & 119 & 65,7 & 20 & N. d. & 35 & 34 & 30 \\
\hline \multicolumn{2}{|c|}{ Iš viso } & $182^{* *}$ & 100,0 & 49 & 22 & 60 & 55 & 53 \\
\hline
\end{tabular}

* Is 37 LNB inicijuotu tyrimu 17-oje dalyvavo (rinko ir teike duomenis, juos analizavo, apibendrino ir pan., priklausomai nuo tyrimo pobūdžio) AVB ir (arba) SVB; kiti 20 tyrimu buvo atlikti SVB veiklos lauke, tačiau SVB personalas į tyrimo procedüras nebuvo įtrauktas.

** Šis skaičius nèra visu atliktų regionuose ir savivaldybèse tyrimu suma: daugeliu atveju, ypač jei tyrima inicijuodavo nacionalinio lygmens institucijos, visuose regionuose buvo atliekami tie patys tyrimai.

Kitos institucijos (be mokslo ir studiju instituciju) savo iniciatyva tiriamuoju laikotarpiu sektoriuje atliko 10 tyrimų, t. y. 5,5 proc. visu tyrimų $(\mathrm{N}=182)$. Keturis iš jų inicijavo savivaldos institucijos rengdamos rajono kultūrinès raidos strategiją, projektus ar kitokius strateginius dokumentus (vienas tyrimas atliktas Panevėžio ir trys Vilniaus regionuose), kiti šeši tyrimai atlikti Vilniaus regiono bibliotekose. Juos atliko Rašytoju sąjungos leidykla, Etninès globos taryba, Lietuvių kalbos institutas.

16 lentelè. Tyrimu paplitimas sektoriaus bibliotekose ir ju pasiskirstymas regionuose

\begin{tabular}{|c|l|l|l|l|}
\hline $\begin{array}{c}\text { Eil. } \\
\text { Nr. }\end{array}$ & \multicolumn{1}{|c|}{ Regionas } & SVB skaičius (iš viso) & $\begin{array}{l}\text { SVB, kuriose buvo } \\
\text { atlikti tyrimai, } \\
\text { skaičius }\end{array}$ & $\begin{array}{l}\text { SVB dalis (proc.) } \\
\text { regiono SVB } \\
\text { struktūroje }\end{array}$ \\
\hline 1. & Kauno regionas & 13 & $8^{*}$ & 61,5 \\
\hline $\mathbf{2 .}$ & Klaipèdos regionas & 11 & Neteikè duomenu & $-71,3^{* *}$ \\
\hline 3. & Panevežio regionas & 12 & 8 & 66,7 \\
\hline $\mathbf{4 .}$ & Šiaulių regionas & 11 & 9 & 81,8 \\
\hline 5. & Vilniaus regionas & 13 & 10 & 76,9 \\
\hline Iš viso & 60 & 35 & $58,3\left(71,6^{* *}\right)$ \\
\hline
\end{tabular}

* Kauno regiono 3 SVB (Kédainiu, Kauno miesto ir Kazlu Rüdos) teigia atlikusios vienokius ar kitokius tyrimus tiriamuoju laikotarpiu, tačiau duomenu apie juos neteikia.

** Skaičiuojant su Klaipedos regiono SVB, tiriamoji veikla paplitusi 71,3 proc. viso sektoriaus teritorijos $(N=49)$. 
Tiriamosios veiklos paplitimo teritorinès ribos (16 lentele) apima beveik du trečdalius (apie 72 proc.) visos šalies teritorijos. Didžiausios sektoriuje veikiančių SVB dalys ị tiriamąją veiklą ịsitraukusios Šiaulių ir Vilniaus regionuose (atitinkamai 81,8 proc. ir 76,9 proc. viso šiuose regionuose esančių SVB bibliotekų tinklo).

Mokslo ir studijų tikslais rengiamų tyrinëjimų laukas teritorijos atžvilgiu palyginti labai mažas ir telkiasi tuose regionuose, kuriuose arba arti kurių (geografinio atstumo atžvilgiu) veikia mokymo įstaigos, kuriose dèstomos bibliotekininkystès, informacijos ir komunikacijos krypties arba artimos šiai krypčiai studiju programos (tiriamuoju laikotarpiu - Šiaulių, iš dalies Panevėžio regionuose).

Kitų institucijų (be mokslo ir studiju institucijų darbu) atliekami tyrinèjimai teritorijoje paplitę mažiausiai. Tokie darbai buvo atliekami 23-ose SVB, arba 38,3 proc. $(\mathrm{N}=60)$ viso bibliotekų tinklo; tyrimo duomenys rodo, jog kitos institucijos tyrinëjimus atliko dažniau tose SVB, kuriose jie buvo atliekami ir pačių SVB pajègomis (12-oje SVB: Kauno r. SVB, Marijampolès SVB, Panevėžio m. SVB, Ignalinos, Joniškio, Šiauliu, Kelmès, Alytaus, Varenos, Lazdijų, Švenčionių r. SVB, Elektrènų SVB).

Išanalizavę sektoriaus bibliotekų ịtraukties ì tiriamąją veiklą duomenis, galime tvirtinti, kad dažniausiai SVB buvo įtraukiamos ị tiriamąsias veiklas pavedant jų specialistams techninio pobūdžio ịpareigojimus (išdalyti anketas, apklausti respondentus, surinkti ir susisteminti duomenis ir pan.). Nacionaliniu mastu dažniausiai buvo atliekami užsakomieji tyrimai analitinių ir konsultacinių firmų, tyrimų agentūrų (UAB „BGI Consulting“, TNS, UAB „Estep“, UAB Socialinès informacijos centro (SIC) jègomis. SVB darbuotojai ị tokių tyrimų procedūras buvo įtraukiami kaip tyrimo objektas (jų buvo prašoma atsakyti ị klausimynus, dalyvauti žodinèse apklausose, ekspertu grupėse ir t. t.). Atliekant tyrimus, kuriuos inicijavo LNB, dalies šių tyrimų partneriais buvo kviečiami AVB specialistai (5 iš 18 , arba 27,8 proc. visų LNB atliktų tyrimų); SVB juose taip pat dalyvavo kaip tyrimų objektas, dažnai atlikdamos ir techninio 
pobūdžio ịpareigojimus. Analogiškas vaidmuo SVB buvo skiriamas ir regioniniuose tyrimuose. Tyrimu objekto vaidmuo SVB buvo skiriamas ir absoliučioje daugumoje mokslo bei studijų ar kitų institucijų atliekamu tyrimų programų.

SVB veiklos lauke atliktų tyrimo darbų temų analizė (17 lentelè, 17 pav.) parodè, kad beveik visais lygmenimis aktyviausiai buvo tyrinèjami bibliotekų paslaugų, jų poreikio, organizavimo (modeliavimo) ir gyventojų bei (arba) bibliotekų vartotojų naudojimosi šiomis paslaugomis klausimai (37,5 proc. visų darbų, $\mathrm{N}=182)$. Galime daryti visiškai pagrịstą prielaidą, kad pagrindinis motyvas atlikti šiuos tyrinejjimus iš esmès yra rinkos diktatas - nuolatinis poreikis pagrịsti bibliotekos kaip institucijos reikalingumą ir visuomenei, ir konkrečiai bendruomenei, ir bibliotekos savininkui, nauju, visuomenès (arba konkrečios bendruomenès) poreikius atitinkančių paslaugu paieška, pasitikrinimas, ar bibliotekų pasirenkama politika teisinga ir efektyvi teikiant ar pasirenkant naujas paslaugas ar ju rinkinius ir teikia galimybę, leidžia numatyti ne tik šios institucijos tolesnès raidos, bet neretai ir jos išlikimo gaires. Plačiau neaptarinèdami tyrinëjimu turinio ir jų rezultatų, galètume teigti, jog šiuo laikotarpiu gana plačiai ir patikimai ištyrinètas SVB vaidmuo užtikrinant šalies gyventoju prieigos prie informacinių išteklių galimybes, gyventoju gebëjimai naudotis IKT, biblioteku veikla stiprinant šiuos gebejjimus ir tokiu pokyčiu poveikis bibliotekų naudotojų gyvenimui. Šie tyrimai gana intensyviai buvo atliekami ir nacionaliniu (daugiausia projekto „Bibliotekos pažangai“ ir „Bibliotekos pažangai 2 “ tyrimų rezultatai), ir regioniniu lygmenimis, tačiau daugiausia jų atlikta pačiu SVB iniciatyva ir pajėgomis. Tenka tik apgailestauti, jog didesnioji dalis SVB šia tema savarankiškai atliktu tiriamojo pobūdžio darbų (apklausų, analizių, vertinimu) sektoriuje neišsaugoti, o dokumentuoti darbai retai atitinka šiam žanrui keliamus reikalavimus. Šie tyrinëjimai fragmentiški, nesistemingi, atspindi situaciją nedidelëje teritorijos dalyje, jų rezultatai įforminti nekokybiškai ir dažnai jau neprieinami, nes nearchyvuojami, neviešinami ir nesaugomi. Dèl šių priežasčių jie gali 
(ar galëjo) būti naudingi tik tai konkrečiai bibliotekai (ar sistemai), kurios veiklos lauko objektai buvo tyrinëjami.

17 lentelè. SVB veiklos lauke atliktu tyrinëjimu pasiskirstymas pagal ju iniciatoriu (arba atlikeju) lygmenis

\begin{tabular}{|c|c|c|c|c|c|c|c|c|}
\hline \multirow[b]{2}{*}{$\begin{array}{l}\text { Eil. } \\
\text { Nr. }\end{array}$} & \multirow[b]{2}{*}{$\begin{array}{l}\text { Pagrindinès tyrinèjimų } \\
\text { temos }\end{array}$} & \multicolumn{5}{|c|}{$\begin{array}{l}\text { Parengta darbų pagal atlikèjų } \\
\text { (ar iniciatoriu) lygmenis }\end{array}$} & \multirow[b]{2}{*}{ 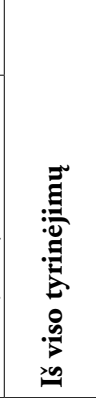 } & \multirow{2}{*}{ 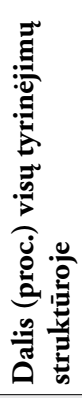 } \\
\hline & & 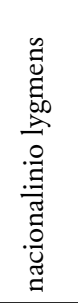 & 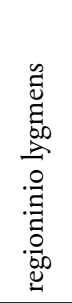 & 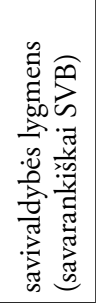 & 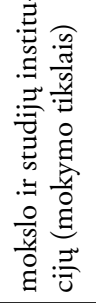 & 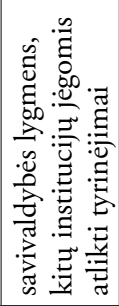 & & \\
\hline 1. & $\begin{array}{l}\text { Biblioteku paslaugu tyri- } \\
\text { nèjimai }\end{array}$ & 6 & 10 & 29 & 16 & 4 & 65 & 35,7 \\
\hline 2. & $\begin{array}{l}\text { Bibliotekų vadybos } \\
\text { problemų tyrimai, strate- } \\
\text { ginių ir taktinių veiklos } \\
\text { organizavimo sprendimų } \\
\text { pagrindimas }\end{array}$ & 12 & 2 & 13 & 0 & 4 & 31 & 17,0 \\
\hline 3. & $\begin{array}{l}\text { Vartotojų elgsenos, skaity- } \\
\text { mo problemų tyrinèjimas }\end{array}$ & 5 & 0 & 6 & 9 & 1 & 21 & 11,5 \\
\hline 4. & $\begin{array}{l}\text { Bibliotekų informaci- } \\
\text { nių išteklių tyrinèjimai } \\
\text { (fondai, jų struktūra, } \\
\text { sudarymo ir panaudojimo } \\
\text { aspektai) }\end{array}$ & 2 & 4 & 11 & 3 & 0 & 20 & 11,0 \\
\hline 5. & $\begin{array}{l}\text { Tyrimai projektinei veiklai } \\
\text { pagristi }\end{array}$ & 16 & 2 & 1 & 0 & 0 & 19 & 10,4 \\
\hline 6. & $\begin{array}{l}\text { Biblioteku veiklos povei- } \\
\text { kio tyrinëjimai }\end{array}$ & 2 & 1 & 1 & 11 & 4 & 19 & 10,4 \\
\hline 7. & $\begin{array}{l}\text { Bibliotekų išorinès aplin- } \\
\text { kos istoriniai, geolingvisti- } \\
\text { niai (tarmiu) tyrinèjimai }\end{array}$ & 0 & 0 & 0 & 1 & 4 & 5 & 2,7 \\
\hline 8. & $\begin{array}{l}\text { Bibliotekų bendradarbiavi- } \\
\text { mo (regioninio, tarptauti- } \\
\text { nio) problemų tyrinëjimai }\end{array}$ & 0 & 1 & 1 & 0 & 0 & 2 & 1,1 \\
\hline \multicolumn{2}{|c|}{ Iš viso } & 43 & 20 & 62 & 40 & 17 & 182 & 100,0 \\
\hline \multicolumn{2}{|c|}{$\begin{array}{l}\text { Dalis (proc.) visų tyrinèjimų } \\
\text { struktūroje }(\mathrm{N}=181)\end{array}$} & 23,6 & 11,0 & 34,1 & 22,0 & 9,3 & 100,0 & \\
\hline
\end{tabular}




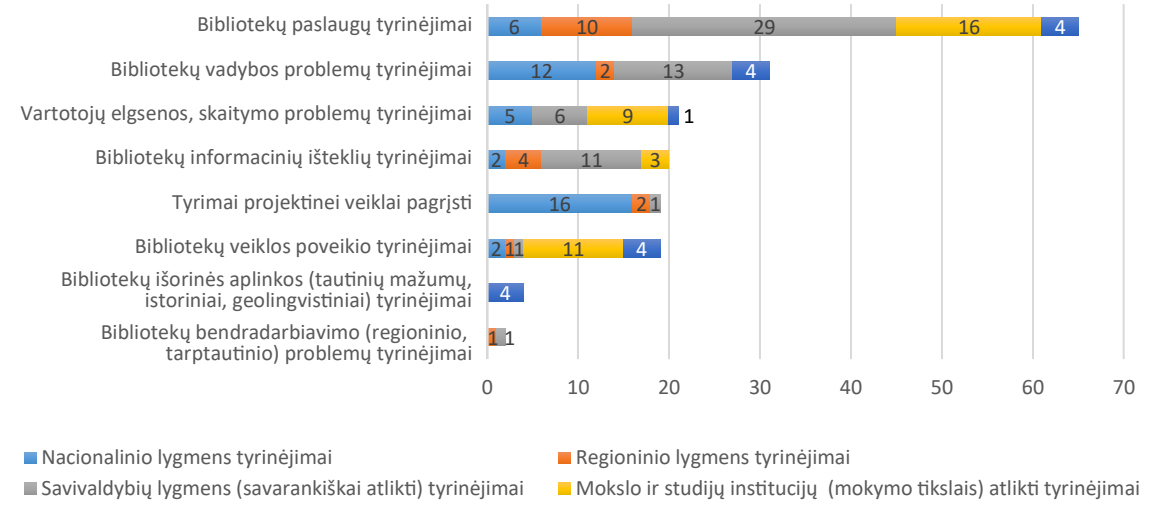

17 pav. SVB veiklos lauke atliktu tyrinëjimu pasiskirstymas pagal ju iniciatoriu (arba atlikeju) lygmenis

Sektoriaus biblioteku vadybos problemos aktyviau tyrinejjamos nacionalinio lygmens institucijų (12, arba 38,7 proc. visų šia tema atliktų tyrinëjimų, $\mathrm{N}=31$ ) ir savarankiškai SVB atliktuose darbuose (13, arba 41,9 proc. visų šia tema atliktų tyrinejjimų, $\mathrm{N}=31$ ). Nacionalinio lygmens tyrinèjimuose dažniau buvo tiriami sektoriaus biblioteku - šiuolaikinëje visuomenëje veikiančių organizacijų veiklos organizavimo ir valdymo, veiklos vertinimo klausimai, o savivaldybių savarankiškai atliekamu tyrimų temos gerokai siauresnès ir dažnai apsiriboja bibliotekos personalui skirtų mokomųjų renginių kokybės vertinimais. Keli darbai skirti rajono biblioteku tinklo pertvarkymo (optimizacijos), personalo motyvacijos ir kompetencijos (tirtas bibliotekininkų skaitymo repertuaras) klausimams.

Palyginti nedaug darbų (21, arba 11,5 proc. visų atliktų tyrinèjimu, $\mathrm{N}=182$ ) skirta vartotojų elgsenos ir skaitymo problemų tyrinèjimams, biblioteku veiklos poveikio tyrimams (19, arba 10,4 proc. visu atliktu tyrinèjimų, $\mathrm{N}=182$ ). Abi šias temas dažniau nei kiti tyrimų organizatoriai nagrinèjo LNB specialistai ir aukštųu mokyklų diplomantai, šia tema keletas darbų parengta ir SVB.

Šie duomenys rodo, kad išorès subjektų iniciatyva ir pajègomis SVB veiklos laukas buvo tyrinejjamas beveik du kartus dažniau (120, arba 
65,9 proc. visų tyrinëjimu), nei tai dare pačios SVB (62, arba 34,1 proc. visų tyrinëjimu). Aktyviausi tyrinèjimų iniciatoriai 2010-2015 m. laikotarpiu buvo Lietuvos Respublikos kultūros ministerija, nacionalinio ir regioninio lygmens korporacinès institucijos, LNB, 5 AVB (63, arba 34,6 proc. visų tyrinëjimu). Aktyvesnę šių institucijų poziciją SVB sektoriuje tiriamosios veiklos srityje lemia ne tik tai, kad joms formaliai priskirtos valdymo (Lietuvos Respublikos kultūros ministerija) arba metodinès (LNB, AVB) veiklos funkcijos, bet ir tai, kad viešųų bibliotekų sektoriuje šiuo laikotarpiu buvo igyvendinami du nacionaliniai projektai.

Nemažą tyrinëjimų dali sudaro ir mokslo bei studijų institucijų inicijuoti ir atlikti darbai (40, arba 22,0 proc. visu tyrinejjimu), kurių pagrindu šių institucijų studentams arba suteikiami kvalifikaciniai laipsniai, arba šie darbai (kursiniai, savarankiški darbai) yra privaloma mokymo proceso dalis.

Kitų išorès institucijų jų pačių poreikiams, šių institucijų iniciatyva ar susitarimų su SVB pagrindu atlikti darbai sudaro palyginti nedaug (17, arba 9,3 proc.) visų tyrinejjimų ir dažniausiai bibliotekos čia tyrinejjamos tiek, kiek jų veikla yra pagrindinio tyrinëjamo objekto (pvz., kultūros paveldo, knygų rinkos, savivaldybès kultūrinio lauko ir t. t.) dalis. Ši tyrinètoju kategorija aktyviausiai dalyvavo atliekant trijų svarbiausių problemu, kurioms sprendimu ieško SVB, analizę ir vertinimą: 2010-2015 m. išorès instituciju profesionalų pajègos buvo skirtos kaimo gyventojų kultūrinių poreikių tyrinëjimams (Aleksandro Stulginskio universitetas, Kalvarijos SVB Kauno regione), laisvalaikio, informacinių ir edukacinių poreikių bibliotekoje analizei (Marijampolès kolegija, Marijampolès r. SVB Kauno regione), skaitytojų poreikio lietuvių ir užsienio autorių kūriniams tyrinèjimui (Lietuvos rašytojų sąungos leidykla, Lazdijų r. SVB, Vilniaus regione); valdymo sprendimų paieškoms - Ignalinos rajono kultūros plètros analizė (užsakomasis tyrimas tyrimų bendrovei, užsakovẻ savivaldybès administracija), bibliotekų veiklų raiška savivaldybių strateginiuose dokumentuose, socialinès atskirties mažinimo, skaitmeninès ịtraukties 
didinimo ir mokymosi visą gyvenimą srityse (užsakovè savivaldybės administracija, Elektrėnų SVB), bibliotekų vaidmens ir jos poveikio socialiniams ir kultūriniams procesams tyrinèjimai (Šiaulių valstybinė kolegija, Šiaulių r. SVB) ir pan.

Iš visų aptartų ir SVB veiklos lauke tiriamuoju laikotarpiu atliktu tyrinèjimų vertingiausi, mūsų požiūriu, galètų būti nacionalinio lygmens institucijų ir mokslo ir studijų tikslais atlikti darbai tiek dèl pasirenkamu temų aktualumo pačioms bibliotekoms, tiek dèl jau pripažintos ir (ar) nuspëjamos geresnès šių darbų kokybės, palyginti su savarankiškai SVB pajegomis atliktais tyrinëjimais. Kitaip tariant, jiems yra ir turètų būti pripažịstama didesnè ir mokslinè, ir praktinè vertè.

Vis dèlto atlikto tyrimo duomenys verčia nuogąstauti, kad su šių darbų, o ypač mokslo ir studijų tikslais atliktais tyrinëjimų rezultatais bibliotekinè bendruomenè menkai susipažinusi, juose pateikiamos ižvalgos arba apskritai ignoruojamos, neaptariamos arba išsamiau neanalizuojamos, surinktais duomenimis nepasinaudojama ne tik veiklos korekcijoms, bet (tai būtų labai racionalu) ir papildomoms jų interpretacijoms, ịvertinant juos patyrusio specialisto praktiko požiūriu. Kitaip tariant, didžioji šių darbų dalis praktinëje bibliotekų veikloje niekaip nepanaudojama, nerenkama, nesaugoma bibliotekų archyvuose, nei nagrinètos temos, nei tyrimų rezultatai neapibendrinami. Dèl to išsklaidomas, lieka nesusistemintas jau turimų žinių, gautų šių tyrinèjimų pagrindu, masyvas, tyrinëjamos temos dubliuojamos, nepagrịstai kartojamos, darbai neviešinami, jų sklaidai skirti renginiai yra itin retas reiškinys bibliotekineje bendruomenëje.

\subsubsection{Savarankiškai SVB atlikti darbai ir jų vertinimas}

Savarankišką SVB indèli i tiriamąją veiklą sektoriuje sudaro 62 darbai (34,1 proc. visų sektoriuje atliktų darbu), kitaip tariant, vidutiniškai vienoje SVB 2010-2015 m. (per 6 metus) savarankiškai buvo atliktas vienas tyrimas. Didžiausią jų dalį sudaro rinkos tyrimams priskiriami darbai arba 
darbai, skirti vadybiniams sprendimams pagristi, kitaip tariant, darbai, kuriems atlikti reikalingesnès vadybininko nei tyrëjo kompetencijos.

Darbai, kurie analizuojami šiame tyrime, yra ịvairaus lygio ir kokybès. Jie vienaip ar kitaip yra arba dokumentuoti ir įvertinti de visu, arba ju įvykdymo faktas užfiksuotas bibliotekų veiklos dokumentuose (veiklos ataskaitose), arba darbai įregistruoti kaip i̇vykdyti pildant šio tyrimo dokumentus.

Vertinti darbų nepateikè nè viena Klaipèdos regiono SVB. Ne visus darbus prisipažista pateikusios ir dalis kitų (Kauno, Šiaulių, Panevèžio ir Vilniaus regionu) SVB. Tokie sprendimai dažniausiai motyvuojami tuo, kad (pačių SVB darbuotojų vertinimu) darbai neatitinka mokslo tiriamajam darbui keliamų reikalavimų. Paprastai jie apibūdinami tik kaip nereikšmingi bandymai tyrinèti, teigiama, kad tai fragmentiški, nedideli darbai, tinkami naudoti nebent bibliotekoje, neturintys jokios arba bent kiek didesnès liekamosios vertès. Dažniausiai jie atliekami lyg „tarp kitko“: pasirenkama (arba pritaikoma) kaip galima paprastesnè metodika, surenkami duomenys, jie sugrupuojami, kartais palyginami ar kaip kitaip ivvertinami ir pateikiami adresatams (struktūrinio padalinio ar bibliotekos vadovams, bibliotekos personalui, partneriams, savivaldos institucijoms ar pan.). Šie darbai paprastai nedokumentuojami, nepublikuojami, nepaliekami bibliotekų archyvuose, o tai reiškia, jog dažnai formaliai nẻ neįtraukiami ị apskaitą kaip darbo rezultatas. Atliktų tyrimų (apklausų, analiziu) rezultatai tinkamai apibendrinami ir aprašomi palyginti retai; itin retai rengiama tyrimo ataskaita ar koks kitas tyrimo rezultatus pristatantis darbas (straipsnis, pranešimas ar pan.). Taip galima tik patvirtinti, kad sektoriaus bibliotekose trūksta ir informacijos, ir duomenų apie tokio pobūdžio darbus.

Remdamiesi turimais duomenimis, galime teigti, kad savarankiškai SVB atlieka darbus kiek didesnëje nei trečioje viso sektoriaus dalyje (22 SVB, arba 36,7 proc. visų SVB, $\mathrm{N}=60$ ). Daugiausia darbų atlikta Panevėžio regiono SVB (26), iš kurių darbų kiekybe išsiskiria 
Zarasų r. SVB (10 darbu), o kokybe - Anykščiu rajono, Panevěžio miesto specialistų atlikti tyrinejjimai (18 lentelè). Palyginti su kitais regionais, kiek daugiau darbų atlikta Kauno regiono SVB (16), iš kurių pagal atliktų darbų skaičių ǐssiskiria Prienu, Jonavos (po 5 darbus) ir Kauno r. SVB (4 darbai). Vilniaus (12) ir Šiaulių regionuose tokių darbų atlikta mažiau (8), iš ju galima minèti kokybiškai atliktus Alytaus m. SVB ir Radviliškio r. SVB darbus.

Didžiausia (56, arba 90,3 proc., $\mathrm{N}=62$ ) savarankiškai atliktų darbų dalis dažniausiai atitinka rinkos tyrimų kategorijai priskiriamus darbus (19 lentele).

18 lentelè. SVB savarankiškai atliktu tiriamuju darbu skaičius ir ju pasiskirstymas regionuose

\begin{tabular}{|c|c|c|c|c|}
\hline $\begin{array}{l}\text { Eil. } \\
\text { Nr. }\end{array}$ & Regionas & $\begin{array}{c}\text { Savivaldybès viešoji } \\
\text { biblioteka }\end{array}$ & $\begin{array}{l}\text { Savarankiškai } \\
\text { atlikta darbų }\end{array}$ & $\begin{array}{c}\text { Dalis (proc.) visų } \\
\text { savarankiškai atliktų } \\
\text { darbų struktūroje }\end{array}$ \\
\hline & Kauno & & 16 & 26,7 \\
\hline 1. & & Prienų r. SVB & 5 & 8,1 \\
\hline 2. & & Jonavos r. SVB & 5 & 8,1 \\
\hline 3. & & Kauno r. SVB & 4 & 6,4 \\
\hline 4. & & Marijampolès SVB & 1 & 1,6 \\
\hline \multirow[t]{4}{*}{5.} & & Kalvarijų SVB & 1 & 1,6 \\
\hline & & Kazlu Rüdos $S V B^{*}$ & Neteike duomenu & \\
\hline & Klaipèdos & Neteikė duomenų & 0 & 0,0 \\
\hline & Panevèžio & & 26 & 41,9 \\
\hline 6. & & Zarasų r. SVB & 10 & 16,3 \\
\hline 7. & & Panevėžio m. SVB & 4 & 6,4 \\
\hline 8. & & Anykščių r. SVB & 3 & 4,8 \\
\hline 9. & & Ignalinos r. SVB & 3 & 4,8 \\
\hline 10. & & Pasvalio r. SVB & 2 & 3,2 \\
\hline 11. & & Visagino SVB & 2 & 3,2 \\
\hline \multirow[t]{2}{*}{12.} & & Biržų r. SVB & 2 & 3,2 \\
\hline & Šiaulių & & 8 & 12,9 \\
\hline 13. & & Joniškio r. SVB & 3 & 4,8 \\
\hline 14. & & Šiaulių m. SVB & 2 & 3,2 \\
\hline 15. & & Kelmès r. SVB & 2 & 3,2 \\
\hline 16. & & Radviliškio r. SVB & 1 & 1,6 \\
\hline
\end{tabular}




\begin{tabular}{|c|c|c|c|c|}
\hline $\begin{array}{l}\text { Eil. } \\
\text { Nr. }\end{array}$ & Regionas & $\begin{array}{c}\text { Savivaldybės viešoji } \\
\text { biblioteka }\end{array}$ & $\begin{array}{l}\text { Savarankiškai } \\
\text { atlikta darbų }\end{array}$ & $\begin{array}{l}\text { Dalis (proc.) visu } \\
\text { savarankiškai atliktų } \\
\text { darbų struktūroje }\end{array}$ \\
\hline & Vilniaus & & 12 & 19,4 \\
\hline 17. & & Elektrėnų SVB & 3 & 4,8 \\
\hline 18. & & Alytaus r. SVB & 3 & 4,8 \\
\hline 19. & & Alytaus m. SVB & 2 & 3,2 \\
\hline 20. & & Varènos r. SVB & 2 & 3,2 \\
\hline 21. & & Lazdijų r. SVB & 1 & 1,6 \\
\hline 22. & & Švenčionių r. SVB & 1 & 1,6 \\
\hline \multicolumn{2}{|c|}{ Iš viso } & 22 SVB & 62 & $100,0(\mathrm{~N}=62)$ \\
\hline \multicolumn{2}{|c|}{$\begin{array}{l}\text { Dalis (proc.) ben- } \\
\text { drose struktūrose }\end{array}$} & 36,7 proc. $(\mathrm{N}=60)$ & $34,1(\mathrm{~N}=182)$ & \\
\hline
\end{tabular}

* ك̌i Kauno regiono SVB informavo, kad 2010 m. buvo atlikti tyrinëjimai, tačiau duomenu neteiké.

Darbų temų analizė atskleidžia, kad trys veiklos sritys 2010$2015 \mathrm{~m}$. buvo tyrinejjamos išsamiau. Daugiau nei puse tyrinėjimu (29, arba 46,8 proc. visų savarankiškai atliktų darbų struktūroje) skirta bibliotekų paslaugų tyrinëjimams; iš jų:

- paslaugu poreikio (16 darbų, arba 25,8 proc. visų savarankiškai atliktų darbų struktūroje) tyrinëjimams;

- paslaugu kokybès (13 darbų, arba 21,0 proc. visų savarankiškai atliktų darbų struktūroje) tyrinèjimams;

- bibliotekų vadybos, strateginių ir taktinių veiklos organizavimo sprendimu pagrindimo (penktadalis darbu - 13 darbu arba 21,0 proc. visų savarankiškai atliktų darbų struktūroje) tyrinëjimams;

- bibliotekos produkto, turimų ir (ar) sukuriamų informacinių išteklių (11 darbų, arba 17,7 proc. visų savarankiškai atliktų darbu) tyrinèjimams;

- visuomenès narių gebejjimams naudotis pagrindinèmis bibliotekos paslaugomis arba potencialios rinkos galimybèms nustatyti (skaitymo problemoms tyrinèti) (dešimtoji dalis -6 , arba 10,3 proc. visu savarankiškai atliktų darbu). 
19 lentelè. Savarankiškai atlikti tiriamieji darbai SVB sektoriuje

\begin{tabular}{|c|c|c|c|c|c|c|c|c|}
\hline \multirow[b]{2}{*}{$\begin{array}{l}\text { Eil. } \\
\text { Nr. }\end{array}$} & \multirow[b]{2}{*}{ Tiriamojo darbo rūšis } & \multirow[b]{2}{*}{ 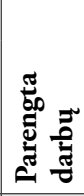 } & \multirow{2}{*}{ 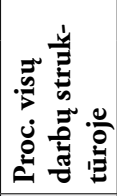 } & \multicolumn{5}{|c|}{ Iš jų atskirų regionų SVB } \\
\hline & & & & 意 & 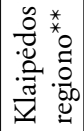 & 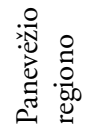 & 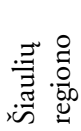 & 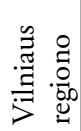 \\
\hline 1. & Moksliniai tyrimai & 1 & 1,6 & 0 & 0 & 1 & 0 & 0 \\
\hline 2. & Rinkos tyrimai, iš jų & 56 & 90,3 & 15 & 0 & 21 & 8 & 6 \\
\hline 2.1 . & $\begin{array}{l}\text { Išorinès ir vidinès aplinkos } \\
\text { tyrimai }\end{array}$ & 19 & 30,6 & 1 & 0 & 10 & 2 & 6 \\
\hline 2.2 . & $\begin{array}{l}\text { Tyrimai vadybiniams sprendi- } \\
\text { mams parengti ir projektinei } \\
\text { veiklai }\end{array}$ & 37 & 59,7 & 14 & 0 & 11 & 6 & 6 \\
\hline 3. & Informaciniai analitiniai darbai* & 2 & 3,2 & 1 & 0 & 1 & 0 & 0 \\
\hline 4. & $\begin{array}{l}\text { Kiti darbai (bibliografijos, } \\
\text { bibliografinès rodykless) }\end{array}$ & 3 & 4,8 & 0 & 0 & 3 & 0 & 0 \\
\hline & & 62 & 100,0 & 16 & 0 & 26 & 8 & 12 \\
\hline \multicolumn{2}{|c|}{$\begin{array}{l}\text { Dalis (proc.) visu savarankiškai atlik- } \\
\text { tų tiriamujų darbų struktüroje }\end{array}$} & & 100,0 & 25,8 & 0,0 & 41,9 & 12,9 & 19,4 \\
\hline
\end{tabular}

* Lenteleje nepateikiamos SVB metu veiklos ataskaitos; tyrimo kontekste jos analizuojamos atskirai kaip SVB atliekamo informacinio analitinio darbo rüsis ir vertinama jų kokybè (plačiau žr. 2.3 .3 skyriuje).

** Klaipedos regiono SVB nepateike AVB tyrejjams atliktu darbu, tačiau ataskaitoje teigiama, jog tiriamosios veiklos faktu regione nustatyta [20, p. 21].

Savarankiškai atliktų darbų vertinimas. Vertinti buvo pateikta 18 darbų iš 11 SVB (20 lentelè); Kauno regione SVB pateiktų darbų nuspręsta nevertinti, nes (Kauno AVB tyrëjų duomenimis) nè vienas iš jų neatitiko minimalių reikalavimų, dèl kurių buvo sutarta ir kurių kriterijai nustatyti tyrimo programiniuose dokumentuose. Klaipèdos regiono SVB nepateikè né vieno darbo, motyvuodamos tuo, jog nèra išsaugotų tinkamai atliktų ar įformintų tyrimų tekstų.

Geriausiai ịvertinti Panevėžio regiono darbai (2,6 balo), prasčiausiai - Vilniaus regiono SVB pateiktas darbas $(1,8)$ balo. Darbo įforminimo kokybè įvertinta gerokai prasčiau: vidutinis visų darbų vertinimas 1,6 balo, aukščiausi balai vertinant šią darbu dalị buvo skirti Panevěžio regiono bibliotekose parengtiems darbams (1,8 balo). (Visi vertinimai pagal 5 balu sistema.) 
Jau aptarta prasta tyrimų kokybė (neprofesionaliai, fragmentiškai surinkti, nepakankami, netikslūs duomenys, iki minimumo supaprastinta tyrinëjimų metodika ir pan. trūkumai) mažina ne tik pačios tiriamosios veiklos efektyvumą, bet dažnai kenkia ir pačioms bibliotekoms: prasta tyrimų kokybè reiškia, kad nenustatomos realios bibliotekos veiklos problemos, o parengti pasiūlymai (jei jie būna rengiami) neatitinka realiu jos poreikiu, taigi ir vadybiniai ar technologiniai sprendimai tampa nepatikimi. Tad būtų teisinga manyti, kad šie darbai (geriausi iš jų) galètų prisidèti tik prie konkrečios bibliotekos darbo pagerinimo, juo labiau kad ir prieiga prie šių duomenų labai ribota arba neįmanoma.

20 lentelè. SVB savarankǐ̌kai parengtu darbų vertinimas (balais, pagal 5 balu sistema)

\begin{tabular}{|c|c|c|c|c|c|c|c|c|c|c|c|c|c|}
\hline \multirow[b]{3}{*}{$\begin{array}{l}\text { Eil. } \\
\text { Nr. }\end{array}$} & \multirow[b]{3}{*}{ Regionas } & \multirow{3}{*}{ 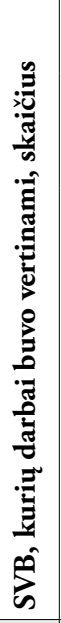 } & \multirow[b]{3}{*}{ 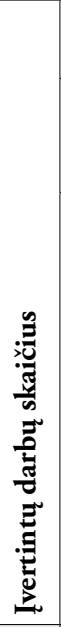 } & \multicolumn{10}{|c|}{$\begin{array}{c}\text { Darbo vertinimas balais (nuo } 0 \text { iki } 5 \text { pagal vertinimo } \\
\text { kriterijus) }\end{array}$} \\
\hline & & & & \multicolumn{5}{|c|}{$\begin{array}{c}\text { Darbo parengimas ir } \\
\text { mokslinis (dalykinis) } \\
\text { baigtumas }\end{array}$} & \multicolumn{4}{|c|}{$\begin{array}{c}\text { Darbo iforminimo } \\
\text { kokybè }\end{array}$} & \multirow[b]{2}{*}{ 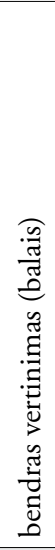 } \\
\hline & & & & 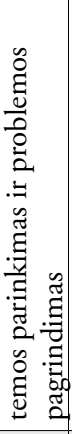 & 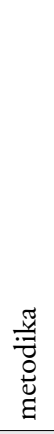 & 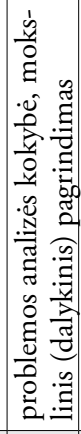 & 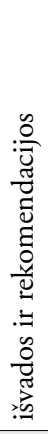 & 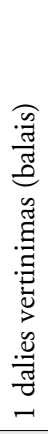 & 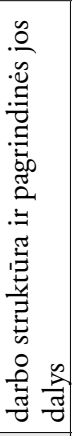 & 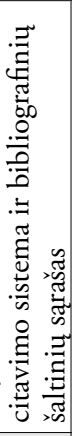 & 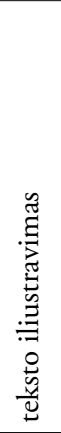 & 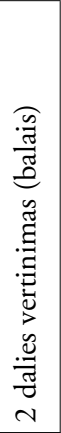 & \\
\hline 1. & Kauno & 0 & 0 & 0 & 0 & 0 & 0 & 0 & 0 & 0 & 0 & 0 & 0 \\
\hline 2. & Klaipèdos & 0 & 0 & 0 & 0 & 0 & 0 & 0 & 0 & 0 & 0 & 0 & 0 \\
\hline 3. & Panevėžio & 6 & 9 & 2,9 & 1,7 & 2,6 & 3,0 & 2,6 & 2,7 & 0,2 & 2,6 & 1,8 & 2,2 \\
\hline 4. & Šiaulių & 4 & 8 & 2,8 & 3,1 & 2,1 & 2,0 & 2,5 & 1,5 & 0,3 & 2,6 & 1,5 & 2,1 \\
\hline 5. & Vilniaus & 1 & 1 & 2,0 & 2,0 & 2,0 & 1,0 & 1,8 & 2,0 & 0 & 1,0 & 1,5 & 1,9 \\
\hline \multicolumn{2}{|c|}{ Iš viso (suma) } & 11 & 18 & & & & & & & & & & \\
\hline \multicolumn{2}{|c|}{$\begin{array}{l}\text { Vidutiniškai regio- } \\
\text { nuose }\end{array}$} & 2,2 & 3,6 & 2,6 & 2,3 & 2,2 & 2,0 & 2,3 & 2,1 & 0,2 & 2,1 & 1,6 & 2,1 \\
\hline
\end{tabular}




\subsubsection{Tiriamosios veiklos rezultatų viešinimas. Darbų prieina- mumas}

Dauguma atliekant tyrimą peržiūrètų ir (arba) vertintų darbų yra nedideli $(2,5,8,11,13$ lapu); nepublikuoti darbai sudaro 72,6 proc. visu atliktų tyrimu, analizių ar apklausų. Lyginant situaciją atskiruose regionuose, daugiausia tyrimų pagrindu parengtų publikuotų darbų yra Panevežio regione (Panevėžio m. SVB, Anykščiu r. SVB, Zarasų r. SVB). Tiesa, iš 10-ies Zarasų viešojoje bibliotekoje atliktų darbų 7 darbai (70 proc.) skirti šioje SVB organizuotiems mokomiesiems renginiams vertinti. Be to, šių apklausų duomenys (prieinami internete) neapibendrinti, neparengta jokių išvadų ar rekomendacijų, kitaip tariant, neparengta net minimalios tyrimo ataskaitos.

Šio regiono Anykščiu r. SVB, Panevėžio m. SVB atliktų darbų pagrindu parengtos publikacijos, jos išspausdintos profesiniuose leidiniuose („Knygotyra“, tinklaraštyje „Rock\&roll bibliotekininkas“).

Kituose regionuose atlikti darbai dažniausiai nepublikuoti. Kai kuriose SVB (daugiausia tokių Kauno regione) tie darbai saugomi juos parengusių biblioteku archyvuose; tik penktadalis (15, arba 21,0 proc.) atliktų tiriamųjų darbų minimi juos parengusių bibliotekų metu veiklos ataskaitose, tačiau dauguma pačių darbų neprieinami (dažniausiai jie arba neišsaugoti archyvuose, arba tiesiog sunaikinti). Bibliotekų metu veiklos ataskaitose tiriamieji darbai Vilniaus regiono SVB įregistruojami dažniau nei kituose regionuose (čia ataskaitose minima per 66,7 proc. visu parengtu darbu). Daugiau nei penktadalio visų savarankiškai parengtų darbų (17, arba 27,4 proc. visu savarankiškai atliktų darbu, $\mathrm{N}=62$ ) saugojimo vieta apskritai nenurodyta ir tai verčia daryti prielaidą, kad visi jie dèl kažkokiu priežasčiu nesaugomi biblioteku archyvuose (21 lentele). Apskričiu viešųjų bibliotekų specialistai, vertinę SVB pateiktus darbus, patvirtina, kad tyrimu ataskaitos „<...> dažnai rengiamos nesilaikant šiems darbams taikomų reikalavimų, pagal kuriuos turi būti suformuluotas tyrimo tikslas ir uždaviniai, atskleista tyrimo problema, pristatyta metodika, nuosekliai 
išanalizuota pasirinkta tema, remiantis tyrimo metu surinktais duomenimis suformuluotos išvados, susietos su tyrimo problema, tikslais ir uždaviniais, pateiktos rekomendacijos $\langle\ldots .$. “. Biblioteku metų veiklos ataskaitose taip pat,$<\ldots>$ darbai pristatomi labai lakoniškai, nenurodant jų tikslų, neaptariant rezultatu, nepateikiant išvadu, o kartais minimas tik pats faktas, kad toks darbas buvo atliktas“ [12, p. 34, 35]. Tik nedaug SVB tyrèjams pateikè tyrimų (apklausu) apibendrinimus (ataskaitas, pranešima), o ne mažiau kaip pusės (apie 48 proc.) 2010-2015 m. atliktų apklausų ataskaitos ar kita dokumentuota informacija (apžvalga, apibendrinimas, straipsnis, pranešimas ir pan.) neišliko arba tiriamojo darbo rezultatus apibendrinantis dokumentas iš viso nebuvo parengtas.

21 lentelè. Prieigos prie SVB savarankiškai atliktu tyrimų duomenu galimybès

\begin{tabular}{|c|c|c|c|c|c|c|c|c|c|}
\hline \multirow{4}{*}{$\begin{array}{l}\text { Eil. } \\
\text { Nr. }\end{array}$} & \multirow{4}{*}{ Regionas } & \multirow{4}{*}{$\begin{array}{c}\text { Irs } \\
\text { viso } \\
\text { darbų }\end{array}$} & \multicolumn{7}{|c|}{ Iš jų } \\
\hline & & & \multicolumn{3}{|c|}{ publikuotų } & \multicolumn{4}{|c|}{ nepublikuotų } \\
\hline & & & \multirow[b]{2}{*}{$\begin{array}{l}\text { iš } \\
\text { viso }\end{array}$} & \multicolumn{2}{|c|}{ iš jų } & \multirow[b]{2}{*}{$\begin{array}{c}\text { iš } \\
\text { viso }\end{array}$} & \multicolumn{3}{|c|}{ iš ju } \\
\hline & & & & $\begin{array}{l}\text { leidi- } \\
\text { niuo- } \\
\text { se }\end{array}$ & $\begin{array}{l}\text { inter- } \\
\text { neto } \\
\text { prieiga }\end{array}$ & & $\begin{array}{l}\text { sau- } \\
\text { goma } \\
\text { SVB }\end{array}$ & $\begin{array}{l}\text { minima } \\
\text { veiklos atas- } \\
\text { kaitose }\end{array}$ & $\begin{array}{l}\text { saugojimo } \\
\text { vieta nenu- } \\
\text { rodyta }\end{array}$ \\
\hline 1. & Kauno & 16 & 0 & 0 & 0 & 16 & 8 & 0 & 8 \\
\hline 2. & Klaipèdos & 0 & 0 & 0 & 0 & 0 & 0 & 0 & 0 \\
\hline 3. & Panevèžio & 26 & 15 & 3 & $12^{*}$ & 11 & 7 & 2 & 2 \\
\hline 4. & Šiaulių & 8 & 1 & 1 & 0 & 7 & 0 & 3 & 4 \\
\hline 5. & Vilniaus & 12 & 1 & 0 & 1 & 11 & 0 & 8 & 3 \\
\hline \multicolumn{2}{|c|}{ Iš viso } & 62 & 17 & 4 & $13^{*}$ & 45 & 15 & 13 & 17 \\
\hline \multicolumn{2}{|c|}{$\begin{array}{l}\text { Dalis (proc.) } \\
\text { visų darbų } \\
\text { struktūroje } \\
(\mathrm{N}=62)\end{array}$} & 100,0 & 27,4 & 6,4 & 21,0 & 72,6 & 24,2 & 21,0 & 27,4 \\
\hline
\end{tabular}

* Panevežio regiono (Zarasu SVB) 7-iu atliktu darbu internete galima rasti tik neapibendrintus atsakymu i klausimus rezultatus.

Mokslo tiriamujų darbu viešinimas. Specialiosioms (bibliotekininkystès, informacijos ir komunikacijos srities) mokslo žinioms ir mokslo tiriamajai veiklai viešinti sektoriaus bibliotekose $2010-2015 \mathrm{~m}$. buvo organizuoti 24 renginiai, arba vidutiniškai per metus 4 renginiai viso sektoriaus 
viešosiose bibliotekose (60 SVB). Renginių paplitimo ribos yra kuklios: jie vyko 11-oje SVB, arba mažiau nei penktadalyje (18,3 proc.) viso sektoriaus bibliotekų, o didesnioji jų dalis - Panevėžio regiono bibliotekose (Panevėžio m. SVB, Biržų, Zarasų, Ignalinos, Pasvalio r. SVB, Visagino SVB) ir Šiaulių regiono (Joniškio, Kelmès r. SVB, Šiaulių m. SVB) bibliotekose (22 lentelè). İ šią grupę pateko dvi Vilniaus regiono SVB (Alytaus m. SVB ir Elektrènų r. SVB) ir viena SVB iš Kauno regiono (Marijampolès SVB).

Dažniausiai tyrimų rezultatams ar kitoms šios srities žinioms populiarinti buvo rengiamos konferencijos (10, arba 41,7 proc. visu organizuotu renginiu), tyrimų rezultatai pristatomi darbuotojų susirinkimuose (8, arba 33,3 proc. visų organizuotų renginiu) arba darbuotojų seminaruose (4, arba 16,7 proc. visų organizuotų renginių). Kitaip tariant, pagrindinis šių žinių sklaidos adresatas - profesinè bendruomenè, be to, palyginti nedidelès žmonių grupès, specializuotų konferencijų dalyviai arba ir vienos institucijos darbuotojai. Elektrènų SVB (Vilniaus regionas) vienintelè sektoriuje savivaldybės bendruomenei organizavo du renginius, kuriuose buvo pristatyti bendruomenès paauglių ir jaunimo poreikių tyrinëjimo rezultatai.

22 lentelè. Renginiai, skirti mokslo tiriamosios veiklos sklaidai, ir ju paplitimo ribos

\begin{tabular}{|c|c|c|c|c|c|c|}
\hline \multirow[b]{2}{*}{$\begin{array}{l}\text { Eil. } \\
\text { Nr. }\end{array}$} & \multirow[b]{2}{*}{ Renginio rūšis } & \multirow[b]{2}{*}{ 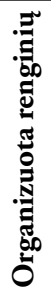 } & \multirow[b]{2}{*}{ 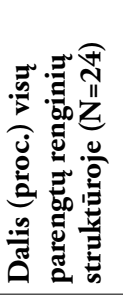 } & \multicolumn{2}{|c|}{ Renginių organizatoriai } & \multirow[b]{2}{*}{ 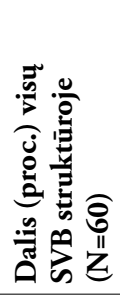 } \\
\hline & & & & 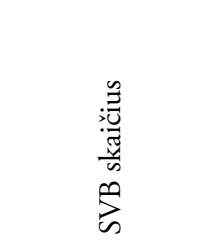 & 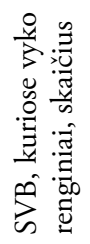 & \\
\hline \multirow[t]{6}{*}{1.} & Konferencijos & 10 & 41,7 & & 8 & 13,3 \\
\hline & & & & Biržų r. SVB & & \\
\hline & & & & Zarasu r. SVB & & \\
\hline & & & & Alytaus m. SVB & & \\
\hline & & & & Ignalinos r. SVB & & \\
\hline & & & & $\begin{array}{l}\text { Marijampolès } \\
\text { SVB }\end{array}$ & & \\
\hline
\end{tabular}




\begin{tabular}{|c|c|c|c|c|c|c|}
\hline \multirow[b]{2}{*}{$\begin{array}{l}\text { Eil. } \\
\text { Nr. }\end{array}$} & \multirow[b]{2}{*}{ Renginio rūšis } & \multirow[b]{2}{*}{ 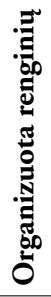 } & \multirow[b]{2}{*}{ 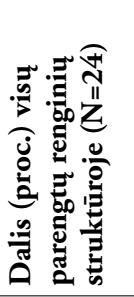 } & \multicolumn{2}{|c|}{ Renginių organizatoriai } & \multirow[b]{2}{*}{ 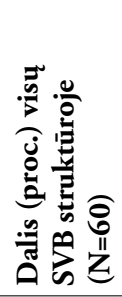 } \\
\hline & & & & 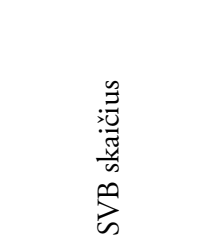 & 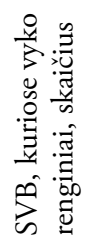 & \\
\hline & & & & $\begin{array}{l}\text { Panevéžio m. } \\
\text { SVB }\end{array}$ & & \\
\hline & & & & Pasvalio r. SVB & & \\
\hline & & & & Visagino SVB & & \\
\hline 2. & $\begin{array}{l}\text { Pristatymai bendruo- } \\
\text { menei }\end{array}$ & 2 & 8,3 & Elektrėnų SVB & 1 & 1,7 \\
\hline 3. & Seminarai & 4 & 16,7 & Biržų r. SVB & 1 & 1,7 \\
\hline 4. & $\begin{array}{l}\text { Darbuotoju pasitarimai } \\
\text { (susirinkimai) }\end{array}$ & 8 & 33,3 & & 5 & 8,3 \\
\hline & & & & Joniškio r. SVB & & \\
\hline & & & & Alytaus m. SVB & & \\
\hline & & & & Kelmės r. SVB & & \\
\hline & & & & Šiaulių m. SVB & & \\
\hline & & & & Zarasų r. SVB & & \\
\hline \multicolumn{2}{|c|}{ Iš viso } & 24 & 100,0 & $11 \mathrm{SVB}$ & 15 & 25,0 \\
\hline
\end{tabular}

Didesniam klausytojų ratui tyrimų duomenys buvo pristatomi kitų instituciju organizuojamuose renginiuose. Tam tiriamuoju laikotarpiu SVB specialistai parengè 10 pranešimų (23 lentele); šios veiklos paplitimo arealas - nedidelè dalis Panevežio regiono (Pasvalio, Biržų, Anykščių r. SVB) ir viena SVB Šiaulių regione (Telšių r. SVB), arba 6,7 proc. viso sektoriaus biblioteku. Aktyviausiomis tiriamuoju laikotarpiu šioje srityje galima laikyti Pasvalio ir Biržų r. SVB; tačiau Biržų r. SVB dažniau šias žinias skleidè savo teritorijoje ir profesinei bendruomenei organizuojamuose renginiuose, o Pasvalio r. SVB - platesnei profesinei bendruomenei regioninio lygmens renginiuose, Anykščiu r. SVB - nacionalinio, o Telšių r. SVB - ir tarptautinio lygmens renginiuose. Auditorija, kuriai atskleidžiamos SVB surastos 
naujos žinios, taip pat paprastai yra profesinè (apskričių viešųjų bibliotekų specialistai, LNB specialistai, SVB darbuotojai). Tiriamuoju laikotarpiu tik vienas pranešimas buvo skaitytas Lietuvių literatūros ir tautosakos institute. Tad ir šiuo atveju galime teigti, kad SVB mokslo tiriamosios veiklos rezultatai retai išeina už institucinių ribų, itin retai pristatomi kitų sričių specialistams ir (ar) bendruomenei, kurioje veikia SVB.

23 lentelè. Pranešimai, skirti mokslo tiriamosios veiklos sklaidai,

ir ju rengeju paplitimo ribos

\begin{tabular}{|c|c|c|c|c|}
\hline $\begin{array}{l}\text { Eil. } \\
\text { Nr. }\end{array}$ & $\begin{array}{l}\text { Pranešimų } \\
\text { autorių darbo } \\
\text { vieta (SVB } \\
\text { pavadinimas) }\end{array}$ & $\begin{array}{l}\text { Pa- } \\
\text { rengta } \\
\text { prane- } \\
\text { šimų }\end{array}$ & $\begin{array}{l}\text { Dalis (proc.) } \\
\text { visų parengtų } \\
\text { pranešimų } \\
\text { struktūroje } \\
(\mathrm{N}=10)\end{array}$ & $\begin{array}{l}\text { Pranešimas skaitytas } \\
\text { (vieta, renginys) }\end{array}$ \\
\hline 1. & Anykščių r. SVB & 1 & 10,0 & $\begin{array}{l}\text { Lietuvos nacionalinèje Martyno Mažvydo } \\
\text { bibliotekoje, konferencijoje }\end{array}$ \\
\hline \multirow[t]{3}{*}{2.} & Biržų r. SVB & 3 & 30,0 & Biržų r. SVB, seminare \\
\hline & & & & Biržų r. SVB, seminare \\
\hline & & & & Biržų r. SVB, seminare \\
\hline \multirow[t]{4}{*}{3.} & Pasvalio r. SVB & 4 & 40,0 & $\begin{array}{l}\text { Lietuvių literatūros ir tautosakos institute, } \\
\text { konferencijoje }\end{array}$ \\
\hline & & & & Klaipedos AVB, konferencijoje \\
\hline & & & & Šiaulių AVB, konferencijoje \\
\hline & & & & Panevėžio AVB, konferencijoje \\
\hline \multirow[t]{2}{*}{4.} & Telšių r. SVB & 2 & 20,0 & $\begin{array}{l}\text { Poznanės viešojoje bibliotekoje (Lenkijos } \\
\text { Respublika), tarptautinëje mokslinëje } \\
\text { konferencijoje }\end{array}$ \\
\hline & & & & $\begin{array}{l}\text { Telšių rajono kultūros darbuotojų semi- } \\
\text { nare }\end{array}$ \\
\hline Iš vi & & 10 & 100,0 & \\
\hline
\end{tabular}

\subsubsection{Metų veiklos ataskaitų vertinimas}

Šiame tyrime SVB metu veiklos ataskaitos vertinamos kaip dokumentas, kuris turètu atitikti analitines ataskaitos kategorijai priskiriamus darbus. Remiantis šiam dokumentui parengti skirtomis rekomendacijomis $[4,5,6,7,8,9]$, viešųų bibliotekų praktika, daroma prielaida, jog tai vienas iš pagrindinių bibliotekų veiklos ịsivertinimo būdų, kurio rezultatais 
remiamasi formuojant bibliotekų vadybos kultūrą, priemonė, padedanti suvokti savo instituciją kaip visumą ir sutarti dèl jos tobulinimo krypčių.

Nors buvo rekomenduota keisti šio dokumento schemą ir jo rengimo principus [7, 8], absoliuti dauguma SVB pasirinko ir iki šiol laikosi dar 2003 m. pateikto metu veiklos ataskaitos modelio [6]. Sektoriaus bibliotekų veiklos ataskaitose paprastai analizuojama 12-13 veiklos sričių, pagal kurias ataskaitos turinys suskirstomas $\mathfrak{i}$ atskirus skyrius: 1) izžanga, arba bendroji dalis; 2) bibliotekų prieinamumas (arba bibliotekų tinklas, jo išsidèstymas teritorijoje); 3) bibliotekos dokumentų fondo formavimas; 4) vartotojų aptarnavimas; 5) vaikų aptarnavimas; 6) informacinè ir kraštotyros veikla; 7) metodinè veikla; 8) mokslinio tyrimo darbas ir dalyvavimas projektuose; 9) žmogiškieji ištekliai; 10) materialinè bazė; 11) finansavimas; 12) apibendrinančioji dalis, arba išvados. Labai retai (1-os SVB iš 118-os tyrinètų darbu, arba 0,8 proc. visų SVB) papildomai išskirtos kai kurios veiklos sritys, pavyzdžiui, „Bibliotekos reklama“, „Bendradarbiavimas su kitomis institucijomis“ (Zarasų r. SVB, 2010 m. ataskaita), arba ataskaitos struktūra sudèliota kitaip, nei rekomenduojama šablone, ir atskiri poskyriai išskirti kitose ataskaitos dalyse (taigi taip pat analizuojama veikla kuriant bibliotekos įvaizdį, aptariant bibliotekos išorinių ryšių organizavimo rezultatus), atskiri skyriai jungiami ị vieną, kai kurių veiklos sričių analizè (pvz., darbas su skaitytojais vaikais, projektinè veikla) įtraukiama ị kitus ataskaitos skyrius. Kai kurios veiklos sritys atskiruose darbuose neanalizuojamos, tik įrašoma pastaba, kad ši veikla neatliekama. Tokie įrašai dažniausiai randami tose ataskaitos dalyse, kuriose pristatoma bibliotekos mokslo tiriamoji veikla.

Visų ịvertintų (2010 ir 2015 m. parengtu) veiklos ataskaitų atitiktis nustatytiems ir suderintiems kriterijams buvo įvertinta vidutiniškai 1,25 balo pagal 5 balų vertinimo sistemą. Atskiruose regionuose parengtų metu veiklos ataskaitų vertinimu skirtumai labai nedideli; galima tik pastebèti, kad palyginti aukštesniu balu nei kituose regionuose îvertintos Klaipedos regiono $2015 \mathrm{~m}$. ataskaitos (1,56 balo, arba $+0,27$ balo, palyginti su tu 
metų šalies vidurkiu (1,29 balo); 24 lentele, 19 pav.), o mažiausiu balu ivertintos Kauno regiono $2010 \mathrm{~m}$. rengtos metu veiklos ataskaitos $(0,89$ balo, arba 0,31 balo, palyginti su tų metu vidurkiu šalyje (1,20 balo). Vertinamu 2015 ir 2010 m. rengtų SVB metų veiklos ataskaitų kokybè, ekspertu nuomone, nors ir labai nedaug, gerejo $(+0,09$ balo, palyginti su 1,20 balo $2010 \mathrm{~m}$. rengtoms ataskaitoms ir 1,29 balo $2015 \mathrm{~m}$. rengtoms ataskaitoms), tiesa, skirtingai atskiruose regionuose. Kauno, Klaipedos ir Šiaulių regionų SVB šių darbų kokybė kiek gerëjo (labiausiai - Klaipėdos regione $+0,23)$, tačiau Panevěžio regiono SVB bendri vertinimo rodikliai liko tie patys (1,41 balo), o Vilniaus regione net šiek tiek mažèjo $(-0,10$ balo, nuo 1,26 balo $2010 \mathrm{~m}$. iki 1,16 balo $2015 \mathrm{~m}$.).

24 lentelè. Metu veiklos ataskaitu vidutinis ivertinimas ir vertinimo skirtumas 2015-2010 m. (pagal 5 balu sistema)

\begin{tabular}{|l|l|c|c|c|c|}
\hline \multirow{2}{*}{$\begin{array}{l}\text { Eil. } \\
\text { Nr. }\end{array}$} & \multicolumn{1}{|c|}{ Regionas } & \multicolumn{3}{|c|}{ Vertinimas balais } & Vidutinis 2015 \\
\cline { 3 - 5 } & $\begin{array}{c}2015 \mathrm{~m} . \\
\text { darbai }\end{array}$ & $\begin{array}{c}2010 \mathrm{~m} . \\
\text { darbai }\end{array}$ & $\begin{array}{c}\text { Pokyčiai } \\
2015-2010 \mathrm{~m} .\end{array}$ & $\begin{array}{c}\text { dar- } \\
\text { bų vertinimas }\end{array}$ \\
\hline 1. & Kauno regiono SVB & 1,06 & 0,89 & $+0,17$ & 0,98 \\
\hline 2. & Klaipédos regiono SVB & 1,56 & 1,33 & $+0,23$ & 1,45 \\
\hline 3. & Panevéžio regiono SVB & 1,41 & 1,41 & 0,00 & 1,41 \\
\hline 4. & Šiaulių regiono SVB & 1,26 & 1,10 & $+0,16$ & 1,18 \\
\hline 5. & Vilniaus regiono SVB & 1,16 & 1,26 & $-0,10$ & 1,21 \\
\hline \multicolumn{2}{|l}{ Vidutinis vertinimas } & $\mathbf{1 , 2 9}$ & $\mathbf{1 , 2 0}$ & $\mathbf{+ 0 , 0 9}$ & $\mathbf{1 , 2 5}$ \\
\hline
\end{tabular}

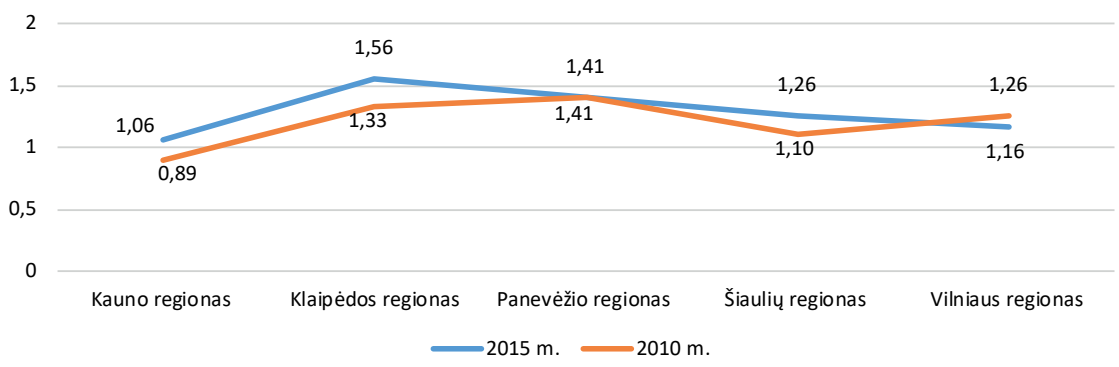

19 pav. Metu veiklos ataskaitu vidutinis ivertinimas ir vertinimo skirtumas 2015-2010 m. (pagal 5 balu sistema) 
25 lenteles duomenys leidžia teigti, kad SVB darbuotojai, rengiantys metų veiklos ataskaitas, šiek tiek geriau išmano šių dokumentų apipavidalinimo, jų įforminimo taisykles ir reikalavimus nei atskirų veiklos sričių analizès metodus. Tai būdinga visiems regionams be išimties (vertinant vidutinius rodiklius); galime pastebėti, jog ryškiausi šie skirtumai Šiaulių ir Klaipèdos regionuose, kuriuose atskiru sričių veiklos analizès kokybès vertinimai atitinkamai $-1,49$ ir $-1,02$ balo mažesni nei darbų iforminimo, jų struktūrinių dalių apimties ir išdèstymo, darbo apipavidalinimo ir iliustravimo vertinimai. Tiesa, ir čia reikia pastebèti, jog regionų lygmeniu abiejų šių dalių vertinimai taip pat neaukšti: nẻ viename regione ir dokumento ifforminimo bei jo pateikimo kokybè neịvertinta patenkinamai; 3-jų regionų (Klaipèdos, Panevèžio ir Šiaulių regionuose) jie ịvertinti kiek aukščiau nei „silpnai“, t. y. kiek daugiau nei 2 balais pagal 5 balų sistemą.

25 lentelè. Metu veiklos ataskaitu atskiru ju daliu (veiklos turinio ir dokumento iforminimo vertinimas (pagal 5 balu sistema)

\begin{tabular}{|c|c|c|c|c|c|}
\hline \multirow[b]{2}{*}{$\begin{array}{l}\text { Eil. } \\
\text { Nr. }\end{array}$} & \multirow[b]{2}{*}{ Regionas } & \multirow[b]{2}{*}{$\begin{array}{l}\text { Bendras } \\
\text { vertinimas } \\
\text { (balais) }\end{array}$} & \multicolumn{3}{|c|}{ Tarp jų } \\
\hline & & & $\begin{array}{l}\text { veiklos sričių } \\
\text { analizès verti- } \\
\text { nimas }\end{array}$ & $\begin{array}{l}\text { dokumento } \\
\text { iforminimo } \\
\text { vertinimas } \\
\end{array}$ & $\begin{array}{c}\text { vertinimuc } \\
\text { skirtumai } \\
\text { (balais) }\end{array}$ \\
\hline 1. & Kauno regiono SVB & 0,98 & 0,90 & 1,48 & $-0,58$ \\
\hline 2. & Klaipèdos regiono SVB & 1,45 & 1,28 & 2,30 & $-1,02$ \\
\hline 3. & Panevèžio regiono SVB & 1,41 & 1,30 & 2,15 & $-0,85$ \\
\hline 4. & Šiaulių regiono SVB & 1,18 & 0,97 & 2,46 & $-1,49$ \\
\hline 5. & Vilniaus regiono SVB & 1,21 & 1,11 & 1,83 & $-0,72$ \\
\hline \multicolumn{2}{|c|}{ Vidutiniškai regionuose } & 1,25 & 1,11 & 2,04 & $-0,93$ \\
\hline
\end{tabular}

Metų veiklos ataskaitose pateikiami vidutiniai atskirų SVB veiklos sričių vertinimai regionuose skiriasi nedaug: aukščiausias vidutinis regiono vertinimas skiriasi 0,4 balo (1,30 Panevėžio regione, palyginti su 0,90 Kauno regione); vidutinis metų veiklos ataskaitų analizės kokybės vertinimas sektoriuje atitinka 1,03 balo pagal 5 balų sistemą (20 pav.). 


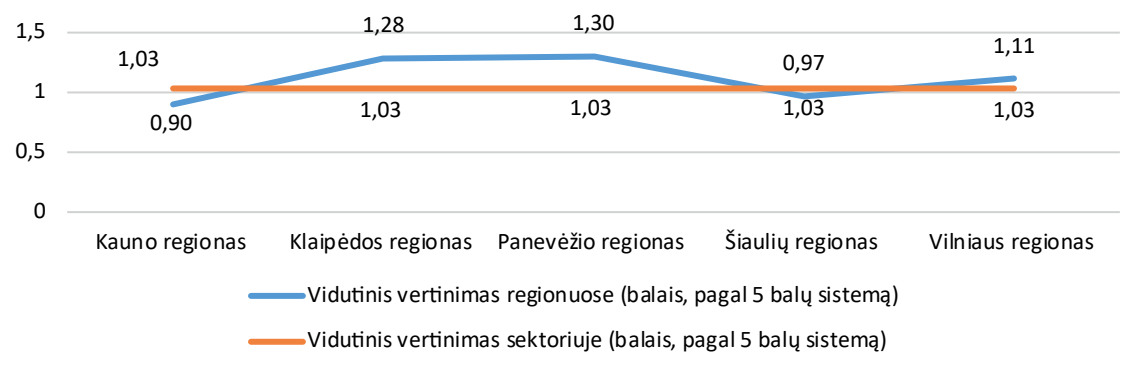

20 pav. Metu veiklos ataskaitu analizés kokybes vertinimas regionuose ir sektoriuje (pagal 5 baly sistema)

Turinio vertinimas. Vidutiniai turinio vertinimo balai yra žemi: bendras vidutinis veiklos turinio analizès kokybès vertinimas yra 1,03 balo, t. y. metų veiklos analizès kokybè yra nepatenkinama, ir dar gerokai žemiau nei vertinimo „silpnai“ (2 balai) ribos. Atskirų veiklos sričių, arba atskirų ataskaitos dalių aukščiausias įvertinimas taip pat nesiekia 2 balų. Visų kitų metų ataskaitos dalių analizės vidutinis kokybės vertinimas dar žemesnis. Tarp regionų geriausiai ịvertintos Panevėžio ir Klaipėdos regionų metų veiklos ataskaitos, prasčiausiai - Kauno ir Šiaulių regionų SVB ataskaitos Vis dèlto, kaip minèta, reikšmingesnių skirtumų nèra, todèl turime pagrindo kalbèti apie visam sektoriui būdingas tendencijas, kurios, jei ir skiriasi vertinant atskiruose rajonuose sukurtus darbus, tai nedaug.

26 lentelè. SVB metu veiklos ataskaitu turinio analizès vertinimai ir jo pokyčiai 2010-2015 metais*

\begin{tabular}{|c|l|c|c|c|}
\hline \multirow{2}{*}{$\begin{array}{c}\text { Eil. } \\
\text { Nr. }\end{array}$} & \multirow{2}{*}{$\begin{array}{c}\text { Regionas ir savivaldybiu } \\
\text { viešosios bibliotekos }\end{array}$} & \multicolumn{3}{|c|}{$\begin{array}{c}\text { Veiklos turinio analizės vertinimai (SVB, kurių } \\
\text { vertinimai yra didesni nei regionų vidurkis } \\
(\mathbf{1 , 1 1} \text { balo) }\end{array}$} \\
\cline { 3 - 5 } & & $\begin{array}{c}\text { 2010 m. veiklos } \\
\text { ataskaita }\end{array}$ & $\begin{array}{c}2015 \text { m. veiklos } \\
\text { ataskaita }\end{array}$ & $\begin{array}{c}\text { Pokyčiai 2015- } \\
\text { 2010 m. (balais) }\end{array}$ \\
\hline $\mathbf{1 .}$ & KAUNO REGIONAS & & & $-0,31$ \\
\hline $\mathbf{1 . 1 .}$ & Jonavos r. SVB & 1,15 & 1,46 & 0 \\
\hline $\mathbf{1 . 2 .}$ & Kaišiadorių r. SVB & 1,46 & 1,46 & $+0,15$ \\
\hline $\mathbf{1 . 3 .}$ & Marijampolès SVB & 1,85 & 2,00 & $-0,23$ \\
\hline $\mathbf{1 . 4 .}$ & Raseinių r. SVB & 1,54 & 1,31 & $+0,84$ \\
\hline $\mathbf{1 . 5 .}$ & Kalvarijos SVB & 0,31 & 1,15 & \\
\hline
\end{tabular}




\begin{tabular}{|c|c|c|c|c|}
\hline \multirow{2}{*}{$\begin{array}{l}\text { Eil. } \\
\text { Nr. }\end{array}$} & \multirow{2}{*}{$\begin{array}{l}\text { Regionas ir savivaldybių } \\
\text { viešosios bibliotekos }\end{array}$} & \multicolumn{3}{|c|}{$\begin{array}{l}\text { Veiklos turinio analizès vertinimai (SVB, kurių } \\
\text { vertinimai yra didesni nei regionų vidurkis } \\
(1,11 \text { balo) }\end{array}$} \\
\hline & & $\begin{array}{c}2010 \text { m. veiklos } \\
\text { ataskaita }\end{array}$ & $\begin{array}{c}2015 \text { m. veiklos } \\
\text { ataskaita }\end{array}$ & $\begin{array}{l}\text { Pokyčiai 2015- } \\
2010 \text { m. (balais) }\end{array}$ \\
\hline 2. & KLAIPĖDOS REGIONAS & & & \\
\hline 2.1. & Klaipèdos r. SVB & 1,00 & 1,50 & $+0,50$ \\
\hline 2.2 . & Klaipèdos m. SVB & 1,20 & 1,50 & $+0,30$ \\
\hline 2.3 . & Neringos SVB & 1,00 & 1,40 & $+0,40$ \\
\hline 2.4. & Kretingos r. SVB & 1,40 & 1,30 & $-0,10$ \\
\hline 2.5 . & Jurbarko r. SVB & 1,30 & 1,00 & $-0,30$ \\
\hline 2.6. & Pagègių SVB & 1,20 & 1,20 & 0 \\
\hline 2.7 . & Šilutès r. SVB & 1,60 & 2,20 & $+0,60$ \\
\hline 2.8. & Šilalès r. SVB & 1,00 & 1,40 & $+0,40$ \\
\hline 3. & PANEVĖŽIO REGIONAS & & & \\
\hline 3.1 . & Anykščių r. SVB & 1,08 & 1,23 & $+0,15$ \\
\hline 3.2. & Biržų r. SVB & 1,54 & 1,46 & $-0,08$ \\
\hline 3.3. & Ignalinos r. SVB & 1,38 & 0,85 & $-0,53$ \\
\hline 3.4. & Kupiškio r. SVB & 2,54 & 2,62 & $+0,08$ \\
\hline 3.5 . & Panevėžio m. SVB & 1,54 & 1,62 & $+0,11$ \\
\hline 3.6. & Pasvalio r. SVB & 1,15 & 1,38 & $+0,23$ \\
\hline 3.7. & Zarasų r. SVB & 2,23 & 2,00 & $-0,23$ \\
\hline 4. & ŠIAULIŲ REGIONAS & & & \\
\hline 4.1. & Akmenès r. SVB & 1,25 & 1,25 & 0 \\
\hline 4.2. & Joniškio r. SVB & 1,33 & 1,25 & $-0,08$ \\
\hline 4.3. & Kelmès r. SVB & 1,50 & 2,67 & $+1,17$ \\
\hline 4.4. & Pakruojo r. SVB & 1,17 & 1,92 & $+0,75$ \\
\hline 4.5. & Šiaulių m. SVB & 1,17 & 0,50 & $-0,67$ \\
\hline 4.6. & Telšių r. SVB & 1,17 & 1,33 & $+0,16$ \\
\hline 5. & VILNIAUS REGIONAS & & & \\
\hline 5.1. & Alytaus m. SVB & 1,42 & 1,50 & $+0,08$ \\
\hline 5.2 . & Druskininkų SVB & 1,17 & 1,00 & $-0,17$ \\
\hline 5.3. & Elektrènų SVB & 2,17 & 1,33 & $-0,84$ \\
\hline 5.4 . & Šalčininkų r. SVB & 1,17 & 1,08 & $-0,09$ \\
\hline 5.5 . & Švenčionių r. SVB & 1,33 & 0,92 & $-0,41$ \\
\hline 5.6. & Ukmergès r. SVB & 0,92 & 1,25 & $+0,33$ \\
\hline 5.7. & Vilniaus r. SVB & 1,50 & 1,58 & $+0,08$ \\
\hline
\end{tabular}

* Lenteleje pateikiami tik tu SVB duomenys, kuriu veiklos ataskaitu turinio analizés vertinimai 2010 arba 2015 m. yra aukstesni nei regionu vidurkis (1,11 balo).

Tik kiek daugiau nei pusės (33, arba 55,0 proc. viso sektoriaus) SVB ir 2010 m., ir $2015 \mathrm{~m}$. rengtos metų veiklos ataskaitos jų atskiru veiklos sričių analizei skirtoji dalis buvo įvertinta geriau nei bendras regionų SVB 
ataskaitų vertinimo vidurkis (1,11 balo). Tokių SVB yra kiekviename regione: daugiausia Klaipèdos regione -8 , Panevėžio ir Vilniaus regionuose - po 7, Šiaulių regione - 6, Kauno regione -5 .

26 lentelés duomenys rodo, kad kiek ryškesnè lyderè šioje srityje yra Kelmès r. SVB (Šiaulių regionas) ir Kupiškio r. SVB (Panevėžio regionas), geriau nei kiti darbai įvertintos Zarasų r. SVB (Panevežio regionas), Elektrènų SVB (Vilniaus regionas), Šilutės r. SVB (Klaipėdos regionas) ir Marijampolés SVB (Kauno regionas) metų veiklos ataskaitų dalys, kuriose analizuojamas SVB veiklos turinys.

Lygindami atskirų veiklos sričiu analizès kokybę tiriamojo laikotarpio pradžioje ir jo pabaigoje, galime pastebèti, jog beveik visose išvardytose SVB ji gerëjo; išskyrus Elektrènų SVB $(-0,84$ balo) ir Zarasų $r$. SVB ( $-0,23$ balo). Išsamesnè duomenų analizè leidžia teigti, jog kokybès pokyčiai ryškesni ir vyksta ir teigiama, ir neigiama kryptimis, kai keičiasi ataskaitos rengèjų grupès sudètis arba atsakingas už ataskaitos parengimą asmuo (pvz., Kelmès r. SVB +1,1 balo, Rietavo r. SVB +0,6 balo, Širvintų r. SVB $+0,21$ balo, tačiau Ignalinos r. SVB $-0,53$ balo, Elektrènų SVB $-0,78$ balo, Alytaus r. SVB $-0,36$ balo ir pan.).

Aukščiausiais balais įvertinti „techniniai“ tiriamų dokumentų aspektai, o ne jų turinys: tai darbo įforminimas - darbo struktūra, atskiru jo struktūrinių dalių išdèstymas, proporcingumas, pati pristatomo teksto kultūra ir t. t.; pateikiamo teksto iliustravimo kokybè - duomenu pateikimo lentelemis ar diagramomis, kitokia ataskaitose teikiamų duomenų ar faktų iliustravimo praktika (21 pav.).

Tyrinètų darbų turinio, atskiru veiklos sričių analizès kokybè ịvertinta prasčiau: vidutiniškai 1,03 balo pagal 5 balų sistemą, kitaip tariant, atsižvelgiant i pasirinktus tyrimo vertinimo kriterijus - nepatenkinamai. Prie vertinimo silpnai, arba 2 balų vertinimo pagal 5 balų sistemą, arčiausiai yra dviejų tyrinètų dokumentų dalių - išvadų, arba baigiamosios dalies ir ižanginių tekstų, arba (I. Bendrosios dalies) vertinimai (atitinkamai 1,96 ir 1,72 balo pagal 5 balų sistema). Tyrimo duomenys gana ịtikinamai parodo, 
jog palyginti aukštesniais balais įvertintos tos darbų dalys, kurios tiesiogiai siejasi su profesine bibliotekine veikla: vartotojų aptarnavimo analizei skirta 1,56 balo, fondo sudarymo analizei - 1,41, informacinès ir kraštotyrinès veiklos analizei bei vaiku aptarnavimo analizei - po 1,36 balo.

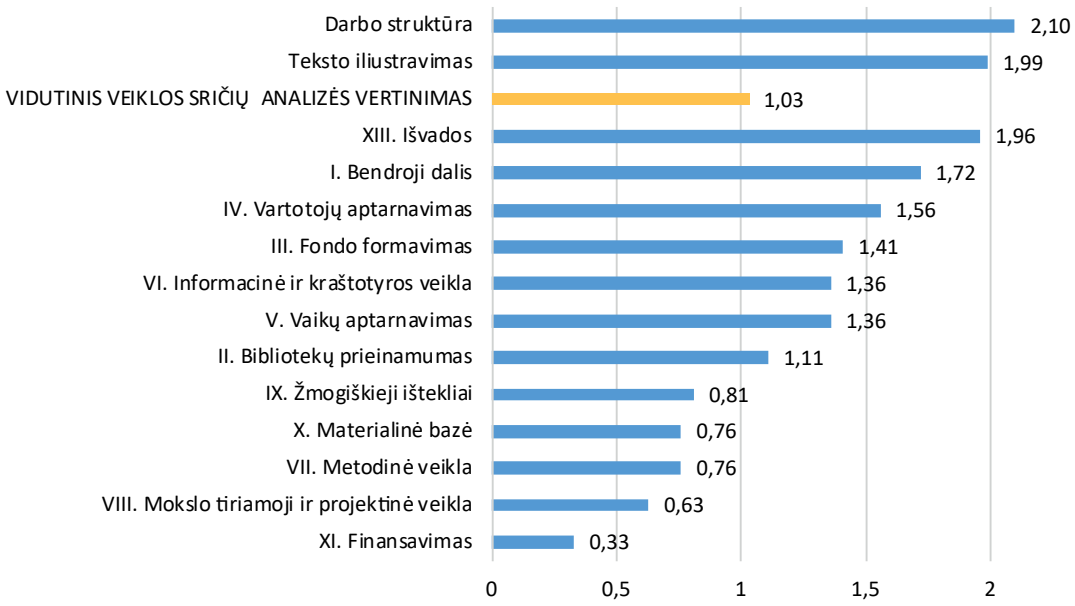

21 pav. Atskiru metu veiklos ataskaitose analizuojamu sričiu analizés kokybès vertinimas (balais, pagal 5 baly sistema)

Sričių, kurios labiau siejasi su SVB kaip organizacijos vadyba, jos veiklos organizavimu, intelektiniu ir materialiniu organizacijos aprūpinimu, vidutiniai vertinimai nesiekia 1 balo. Žemiausiu vidutiniu balu ịvertinta SVB finansavimo būklès ( 0,33 balo pagal 5 balų sistema), mokslo tiriamosios ir projektinès veiklos $(0,63$ balo pagal 5 balu sistema $)$, metodinès veiklos ir materialinès būklès (po 0,76 balo pagal 5 balų sistema) ir žmogiškujjų išteklių ( 0,81 balo pagal 5 balų sistema) analizè.

Kiek geriau, tačiau taip pat labai žemai įvertinta ir ta ataskaitų dalis, kurioje turètų būti analizuojama bibliotekų (kartu ir informacijos, žiniu) prieinamumo aptarnaujamos teritorijos gyventojams, struktūrinių padalinių paskirstymo teritorijoje būklè ir su tuo susijusios problemos (II dalis. Biblioteku prieinamumas, 1,11 balo pagal 5 balų sistema).

Išsamesnè vertinimų analizè rodo (27 lentele), jog labai gerai ( 5 balais pagal 5 balų sistema) neịvertinta nè viena ištirtų dokumentų dalių. 
2010, $2015 \mathrm{~m}$. veiklos ataskaitose gerai (4 balais pagal 5 balu sistema) ivertinta tik 1,1 proc. viso tyrinèto dokumentų masyvo $(\mathrm{N}=1379)$, arba 15 atskirų veiklos sričių, iš kurių dažniau tokiu balu buvo ịvertinti metu veiklos izžangos ir išvadų tekstai. Patenkinamai (3 balais pagal 5 balų sistema) įvertinta kiek daugiau nei dešimtadalis visų analizuotų veiklos sričiu, arba 11,3 proc. viso tyrinèto dokumentų masyvo $(\mathrm{N}=1379)$, silpnai ( 2 balais pagal 5 balų sistemą - penktadalis, arba 20,5 proc. viso tyrinèto dokumentų masyvo $(\mathrm{N}=1379)$. Daugiau nei pusès $(67,1$ proc. viso tyrinèto dokumentų masyvo, $\mathrm{N}=1379)$ analizuojamų veiklos sričių analizės kokybè neatitinka informaciniam analitiniam darbui nustatytų ir šio tyrimo kontekste sutartų vertinimo kriterijų.

27 lentelè. Metu ataskaitos struktüriniu daliu vertinimas

\begin{tabular}{|c|c|c|c|c|c|c|c|c|c|c|c|c|}
\hline \multirow{3}{*}{ Nr. } & \multirow{3}{*}{$\begin{array}{c}\text { Analizuojamos sri- } \\
\text { ties pavadinimas }\end{array}$} & \multicolumn{10}{|c|}{$\begin{array}{c}\text { Vertinimas balais ir konkrečių vertinimų dalis (proc.) } \\
\text { bendrame vertintų tekstų masyve }(\mathrm{N}=1379)\end{array}$} & \multirow{3}{*}{ 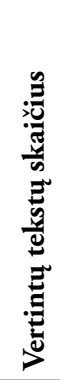 } \\
\hline & & \multicolumn{2}{|c|}{$\begin{array}{c}\text { labai gerai } \\
(5 \text { balai) }\end{array}$} & \multicolumn{2}{|c|}{$\begin{array}{l}\text { gerai } \\
\text { (4 balai) }\end{array}$} & \multicolumn{2}{|c|}{$\begin{array}{l}\text { patenkina- } \\
\text { mai (3 ba- } \\
\text { lai) }\end{array}$} & \multicolumn{2}{|c|}{$\begin{array}{c}\text { silpnai } \\
\text { (2 balai) }\end{array}$} & \multicolumn{2}{|c|}{$\begin{array}{c}\text { nepaten- } \\
\text { kinamai ir } \\
\text { nevertinta } \\
(1+0 \text { balai })\end{array}$} & \\
\hline & & 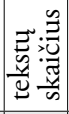 & $\begin{array}{l}\dot{0} \\
\stackrel{0}{a}\end{array}$ & 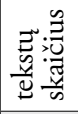 & $\begin{array}{l}\dot{0} \\
\dot{a}\end{array}$ & 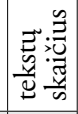 & $\dot{\circ}$ & 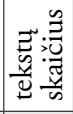 & $\begin{array}{l}\dot{0} \\
\dot{z}\end{array}$ & 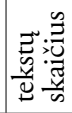 & 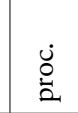 & \\
\hline I. & Bendroji dalis (ižanga) & 0 & 0,0 & 6 & 5,0 & 28 & 23,7 & 26 & 22,0 & 58 & 49,2 & 118 \\
\hline II. & Biblioteku prieinamumas & 0 & 0,0 & 1 & 0,8 & 11 & 9,3 & 20 & 17,0 & 86 & 72,9 & 118 \\
\hline III. & Fondo formavimas & 0 & 0,0 & 0 & 0,0 & 15 & 12,7 & 35 & 29,7 & 68 & 57,6 & 118 \\
\hline IV. & Vartotojų aptarnavimas* & 0 & 0,0 & 1 & 0,8 & 20 & 16,9 & 41 & 34,7 & 56 & 47,5 & 118 \\
\hline V. & Vaikų aptarnavimas* & 0 & 0,0 & 0 & 0,0 & 10 & 10,4 & 28 & 29,2 & 58 & 60,4 & 96 \\
\hline VI. & $\begin{array}{l}\text { Informacinè ir kraštoty- } \\
\text { ros veikla }\end{array}$ & 0 & 0,0 & 0 & 0,0 & 12 & 10,2 & 37 & 31,4 & 69 & 58,5 & 118 \\
\hline VII. & Metodinė veikla & 0 & 0,0 & 1 & 0,8 & 10 & 8,5 & 9 & 7,6 & 98 & 83,1 & 118 \\
\hline VIII. & $\begin{array}{l}\text { Moksliniai tyrimai ir } \\
\text { projektine veikla** }\end{array}$ & 0 & 0,0 & 0 & 0,0 & 6 & 5,1 & 13 & 11,0 & 99 & 83,9 & 118 \\
\hline IX. & Žmogiškieji ištekliai & 0 & 0,0 & 0 & 0,0 & 0 & 0,0 & 17 & 14,4 & 101 & 85,6 & 118 \\
\hline $\mathbf{X}$ & Materialinè bazė & 0 & 0,0 & 1 & 0,8 & 8 & 6,8 & 9 & 7 & 100 & 84,7 & 118 \\
\hline XI. & Finansavimas $^{* * *}$ & 0 & 0,0 & 1 & 1,0 & 0 & 0,0 & 6 & 6,3 & 89 & 92,7 & 96 \\
\hline XII. & \begin{tabular}{|l|} 
Kitos ataskaitos dalys, \\
jei yra specialiai išskirtos
\end{tabular} & 0 & 0,0 & 0 & 0,0 & 1 & 14,3 & 2 & 28,6 & 4 & 57,1 & 7 \\
\hline XIII. & Išvados & 0 & 0,0 & 4 & 3,4 & 35 & 29,7 & 40 & 33,9 & 39 & 33,1 & 118 \\
\hline
\end{tabular}




\begin{tabular}{|c|c|c|c|c|c|c|c|c|c|c|c|c|}
\hline \multirow{3}{*}{ Nr. } & \multirow{3}{*}{$\begin{array}{l}\text { Analizuojamos sri- } \\
\text { ties pavadinimas }\end{array}$} & \multicolumn{10}{|c|}{$\begin{array}{c}\text { Vertinimas balais ir konkrečių vertinimų dalis (proc.) } \\
\text { bendrame vertintų tekstų masyve }(\mathrm{N}=1379)\end{array}$} & \multirow{3}{*}{ 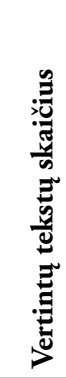 } \\
\hline & & \multicolumn{2}{|c|}{$\begin{array}{c}\text { labai gerai } \\
(5 \text { balai })\end{array}$} & \multicolumn{2}{|c|}{$\begin{array}{l}\text { gerai } \\
\text { (4 balai) }\end{array}$} & \multicolumn{2}{|c|}{$\begin{array}{c}\text { patenkina- } \\
\text { mai ( } 3 \text { ba- } \\
\text { lai) }\end{array}$} & \multicolumn{2}{|c|}{$\begin{array}{c}\text { silpnai } \\
\text { ( } 2 \text { balai) }\end{array}$} & \multicolumn{2}{|c|}{$\begin{array}{c}\text { nepaten- } \\
\text { kinamai ir } \\
\text { nevertinta } \\
(1+0 \text { balai })\end{array}$} & \\
\hline & & 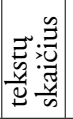 & 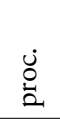 & 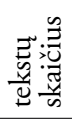 & $\begin{array}{l}\dot{0} \\
\dot{a}\end{array}$ & 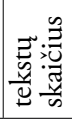 & $\begin{array}{l}\dot{0} \\
\dot{a}\end{array}$ & 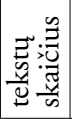 & $\begin{array}{l}\dot{0} \\
\dot{0}\end{array}$ & 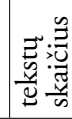 & $\dot{\ddot{\partial}}$ & \\
\hline \multicolumn{2}{|c|}{$\begin{array}{l}\text { Bendras turinio verti- } \\
\text { nimas }\end{array}$} & 0 & 0,0 & 15 & 1,1 & 156 & 11,3 & 283 & 20,5 & 925 & 67,1 & 1379 \\
\hline & $\begin{array}{l}\text { Darbo struktūra ir } \\
\text { pagrindines jos dalys }\end{array}$ & 0 & 0,0 & 1 & 0,8 & 42 & 35,6 & 47 & 39,8 & 28 & 23,7 & 118 \\
\hline & Teksto iliustravimas & 0 & 0,0 & 5 & 4,2 & 32 & 27,1 & 49 & 41,5 & 32 & 27,1 & 118 \\
\hline \multicolumn{2}{|c|}{$\begin{array}{l}\text { Teksto îforminimo ver- } \\
\text { tinimas }\end{array}$} & 0 & 0,0 & 6 & 2,5 & 74 & 31,4 & 96 & 40,7 & 60 & 25,4 & 236 \\
\hline
\end{tabular}

* Vartotoju aptarnavimo analize kai kuriose bibliotekose atliekama kartu su vaiku aptarnavimo analize; Klaipedos regiono biblioteku ataskaitose vaiku aptarnavimo srities analize atskirai nevertinta.

** Metu ataskaitos dalis „Moksliniai tyrimai ir projektine veikla“ Klaipedos regiono SVB dokumentuose pakeista dalimi „Projektiné veikla“.

*** Atliekant tyrima nebuvo pateikti metu ataskaitu dalies ,Finansavimas"vertinimai Klaipédos regiono SVB.

Atskirų veiklos sričių vertinimo balais analizè rodo, kad gerai (4 balais pagal 5 balų sistemą) buvo ịvertinta įžanginių (Bendrosios dalies) ir baigiamujuu, apibendrinamujų (Isvados) tekstų kokybè; tačiau tokie vertinimai palyginti labai reti; taip ivertinti tik 10 -ies (arba 17,0 proc. visu tyrinètų dokumentu, $\mathrm{N}=118$ ) įžanginiai ir (arba) veiklos analizės apibendrinamieji tekstai, kurie buvo parengti Kauno (2), Klaipèdos (6) ir Šiaulių (2) regionų bibliotekose. Dar rečiau tokiu balu buvo įvertintos kitų veiklos sričiu analizės: SVB bibliotekų tinklo ir jo pokyčių bei vertinimų kokybė (Biblioteku prieinamumas), vartotoju aptarnavimo (Vartotoju aptarnavimas) ir finansavimo (Finansavimas) analizè - 1-os SVB (Šiaulių regione) parengtame dokumente, SVB metodinès veiklos (Metodine veikla) ir SVB materialinių išteklių (Materialinè bazè) analizè - 2-uose Kauno regiono SVB parengtuose dokumentuose.

Sektoriuje daugiausia nepatenkinamai ivertinta (1 balas pagal 5 balu sistemą) arba apskritai nevertinta (0 balų) veiklos finansavimo (XI. Finansavimas) ir žmogiškujjų išteklių (IX. Žmogiškieji ištekliai) sričių analizè. Čia 
nepatenkinamai ịvertintų ir nevertintų tekstų dalis sudaro atitinkamai net 92,7 proc. ir 85,6 proc. visų SVB toms sritims analizuoti parengtų dokumentų masyve $(\mathrm{N}=118)$; didžioji dalis (per 80 proc.) nepatenkinamai ịvertintų arba apskritai nevertintų tekstų yra dokumentų dalyse, kuriose analizuojama bibliotekos materialinès bazès būklè, mokslo tiriamasis darbas ir projektinè veikla (atitinkamai 84,7 proc., 83,9 proc. ir 83,1 proc.).

Silpnai (2 balai pagal 5 balų sistema) trečdalyje sektoriaus ịvertinta vartotojų aptarnavimo sritis (34,7 proc. visų analizuotų tos srities tekstu, $\mathrm{N}=118)$, informacinè ir kraštotyros veikla (31,4 proc. visų analizuotų tos srities tekstų, $\mathrm{N}=118$ ). Nors bendras darbuose pateikiamų išvadų vertinimas yra aukštesnis, palyginti su kitomis veiklos sritimis, ir čia galime matyti, jog daugiau nei trečdalyje sektoriaus SVB (33,1 proc. visu analizuotų tos srities tekstu, $\mathrm{N}=118$ ) ši ataskaitų dalis rengiama nepatenkinamai, dar trečdalyje (33,9 proc. visų analizuotų tos srities tekstu, $\mathrm{N}=118$ ) veiklos apibendrinimai formuluojami silpnai, retai įvardijamos metu veiklos problemos, daromos kitos analizès klaidos. Kitaip tariant, ta darbo dalis, kurioje atskleidžiami veiklos rezultatai, iškeltų tikslų ir uždavinių igyvendinimo sèkmès ir nesèkmès, ìvardijamos pagrindinès problemos, kurias būtina spręsti ateinančiais metais, pristatomi rasti (ištirti ar kitaip patvirtinti) efektyvūs sprendimai, galintys sustiprinti vieną ar kitą veiklos sritị (išplètoti, teikti įvairesnes paslaugas, kurti paklausius produktus ir pan.,) ir t. t., tik 4-iuose analizuotuose darbuose, arba 3,4 proc. visu analizuotu tos srities tekstu ( $\mathrm{N}=118)$, rengiama gerai, 35-iuose (arba 29,7 proc. visų analizuotų tos srities tekstu, $\mathrm{N}=118$ ) - patenkinamai.

3 balais (patenkinamai) dažniausiai buvo ịvertinti ataskaitų tekstai, kuriuose pateikiamos išvados ir apibendrinimai (35, arba 29,7 proc. viso šių tekstų masyvo, $\mathrm{N}=118)$, ir įžanginès ataskaitų dalys $(23,7$ proc. viso šių tekstų masyvo, arba 28-ių tyrinètų ataskaitų tekstai, $N=118$ ); vartotoju aptarnavimo dalis patenkinamai vertinta tik nedidelëje tyrinèto masyvo dalyje (20, arba 16,9 proc. viso šių tekstų masyvo, $\mathrm{N}=118$ ), dar mažesnëje sektoriaus dalyje (15-kos, arba 12,7 proc. visų analizuotų tos srities tekstų, 
$\mathrm{N}=118$ ) taip įvertinta ataskaitos dokumentuose bibliotekos informaciniu išteklių arba dokumentų fondui sudaryti (jo struktūrai įvertinti, atnaujinti, kitokių pokyčių analizei ir t. t.) skirtos analizės kokybè.

Nors analitinès ataskaitos apipavidalinimas (darbo struktūra, jos pagrindinių dalių išdèstymas, duomenų pateikimas lentelių ar kitokiu pavidalu, t. y. teksto iliustravimas) buvo įvertintas aukščiau nei turinio analizè, ir šioms sritims nebuvo skirta aukščiausio vertinimo ( 5 balu). 4 balai (vertinimas gerai) skirti tik 6 darbams, arba 5,1 proc. visu analizuotų tos srities darbų ( $\mathrm{N}=118)$; šios sritys taip pat dažniau buvo įvertintos silpnai arba patenkinamai; tokie vertinimai sektoriuje vyrauja ir skirti daugiau nei dviem trečdaliams (72,1 proc.) visų vertintų darbų: silpnai įvertinta 40,7 proc. visų analizuotu darbų $(\mathrm{N}=118)$, patenkinamai - 31,4 proc. visų analizuotų darbu ( $\mathrm{N}=118)$. Nepatenkinamai ịvertinti (1 balas) arba apskritai nevertinti (0 balu) darbai čia sudaro tik kiek daugiau nei ketvirtadali (25,4 proc. visų tyrinètų darbu, $\mathrm{N}=118$ ), o turinio vertinimo duomenys kelia daug didesni nerimą: turinio analizè nevertinta arba įvertinta nepatenkinamai daugiau nei pusès $(67,1$ proc.) visų analizuotų tos srities tekstų $(\mathrm{N}=118)$.

28 lentelè. Metu veiklos ataskaitu atskiru veiklos sričiu vertinimas (balais pagal 5 balu sistema)

\begin{tabular}{|c|c|c|c|c|c|c|c|c|c|c|c|c|c|c|}
\hline Regionas & 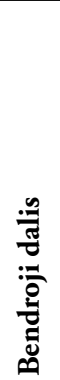 & 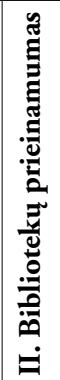 & 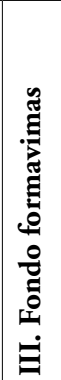 & 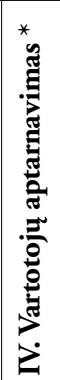 & 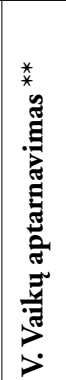 & 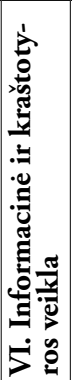 & 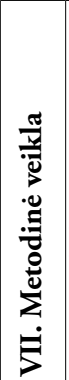 & 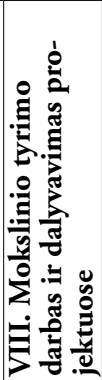 & 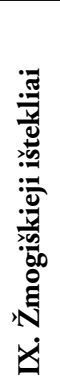 & 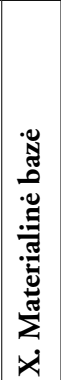 & 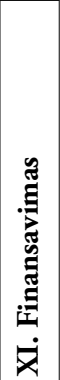 & 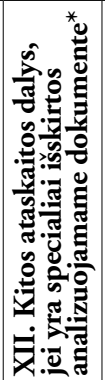 & 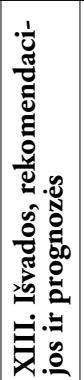 & 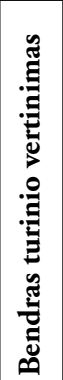 \\
\hline Kauno & 1,92 & 1,04 & 1,17 & 0,92 & 0,71 & 0,58 & 0,71 & 0,92 & 0,63 & 1,21 & 0,42 & 0,13 & 1,38 & 0,90 \\
\hline Klaipèdos & 2,18 & 1,05 & 1,95 & 1,82 & Nèra & 1,23 & 0,32 & 0,32 & 1,09 & 0,45 & Nèra & Nèra & 2,36 & 1,28 \\
\hline Panevèžio & 1,83 & 1,25 & 1,42 & 1,67 & 1,46 & 1,63 & 1,79 & 1,13 & 0,88 & 0,92 & 0,46 & 0,33 & 2,13 & 1,30 \\
\hline Šiaulių & 1,36 & 1,00 & 1,05 & 1,64 & 1,09 & 1,32 & 0,73 & 0,45 & 0,55 & 0,18 & 0,18 & Nèra & 2,09 & 0,97 \\
\hline Vilniaus & 1,27 & 1,19 & 1,38 & 1,65 & 1,46 & 1,92 & 0,23 & 0,31 & 0,92 & 0,92 & 0,27 & Nèra & 1,77 & 1,11 \\
\hline $\begin{array}{l}\text { Vidutinis } \\
\text { vertinimas }\end{array}$ & 1,72 & 1,11 & 1,41 & 1,56 & 1,21 & 1,36 & 0,76 & 0,63 & 0,81 & 0,76 & 0,33 & 0,09 & 1,96 & 1,03 \\
\hline
\end{tabular}


Nors ir nedaug, kiekviename regione atskirų veiklos sričių analizės kokybè skiriasi (28 lentele). Kauno regione, palyginti su kitais regionais, geresne analizès kokybe išsiskiria materialinès bazės analizè, tačiau palyginti prasčiau nei kitur analizuojamas vartotojų aptarnavimas, informacinè ir kraštotyrinè veikla; prasčiausiai šio regiono bibliotekose parengiamos išvados.

Klaipedos regione, palyginti su kitais regionais, geriau rengiama bendrosios dalies (ižzangos) medžiaga, analizuojamos dokumentų fondo sudarymo, vartotojų aptarnavimo ir žmogiškųjų išteklių sritys, kokybiškiau rengiamos metu veiklos analizès išvados ir rekomendacijos, prasčiau - projektinès veiklos, finansavimo klausimai. Reikia pastebėti, kad šio regiono bibliotekos veiklos ataskaitose neanalizuoja mokslo tiriamosios veiklos (ataskaitose nèra tokios struktūrinès dalies, analizuojama tik projektinè veikla), vaikų aptarnavimo analizė integruota ị vartotojų aptarnavimo analizès tekstus ir taip pat neanalizuojama kaip atskira veiklos sritis.

Panevėžio regiono bibliotekose geriau nei kituose regionuose analizuojami bibliotekų prieinamumo, vaikų aptarnavimo klausimai, metodiné, mokslo tiriamoji ir projektinè veikla, finansavimo sritis; šio regiono SVB veiklos ataskaitose nèra veiklos srities, kurios analizès kokybè, palyginti su kitais regionais, išsiskirtų neigiamomis charakteristikomis. Kaip ir kituose regionuose, palyginti su kitomis sritimis, prasčiau analizuojami žmogiškųjų išteklių, materialinès bazès klausimai.

Šiaulių regione, priešingai nei Panevėžio regione, nèra veiklos srities, kuri išsiskirtu iš kitų regionu geriausiomis kokybinèmis veiklos analizės charakteristikomis; šiame regione prasčiau nei kituose regionuose analizuojami bibliotekų prieinamumo, fondo formavimo, žmogiškuju išteklių, materialinès bazès ir finansavimo klausimai. Vilniaus regiono bibliotekose geriau nei kitur analizuojama bibliotekų informacinè ir kraštotyros veikla, vaiku aptarnavimo klausimai, geresne kokybe pasižymi ir vartotojų aptarnavimo analizè. Palyginti su kitais regionais, Vilniaus regione prasčiausia yra bendrosios dalies (ižangos) informacijos ir jos analizès kokybè, metodinès veiklos, mokslo tiriamosios veiklos bibliotekose analizè. 


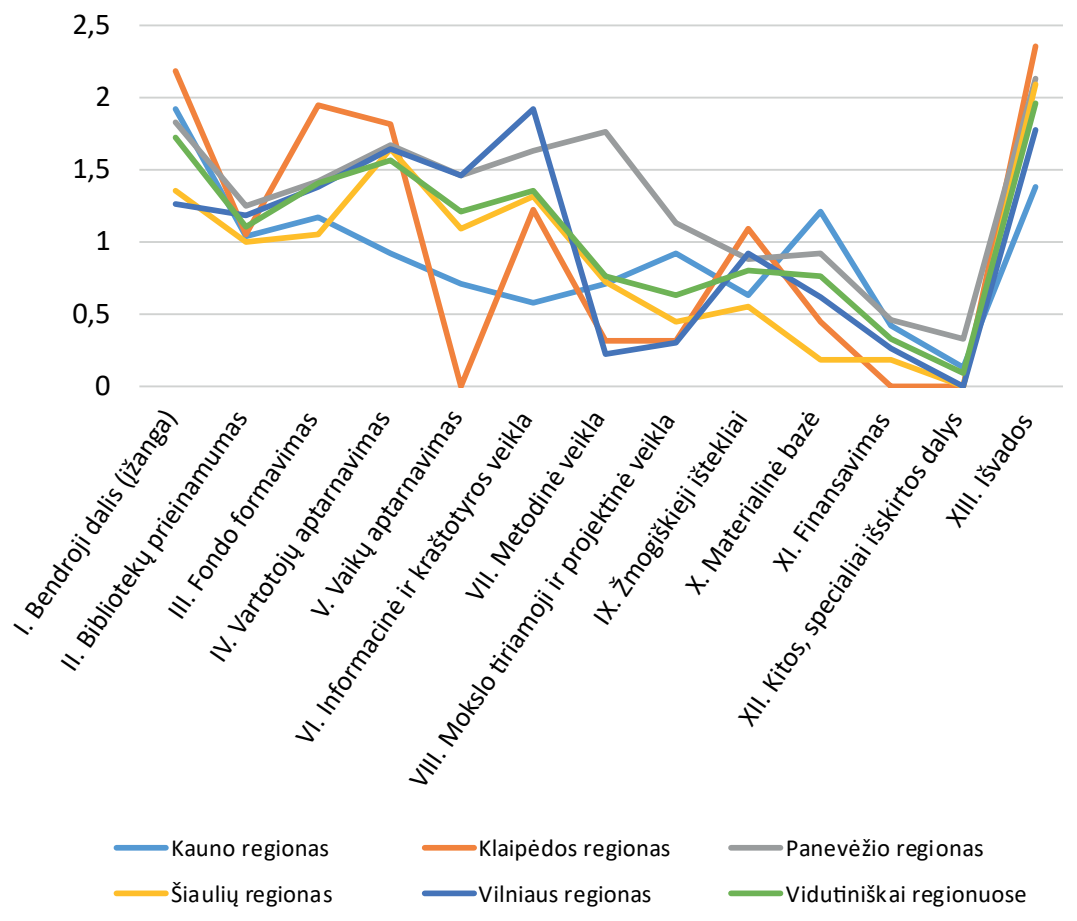

22 pav. Metu veiklos ataskaitu atskiru veiklos sričiu vertinimas regionuose (balais pagal 5 balu sistema)

Apibendrindami turime padaryti išvadą, jog absoliuti dauguma šių dokumentų neatitinka informacinio analitinio žanro, taigi ir analitinès ataskaitos reikalavimų. Vertinant šiuo atžvilgiu, galètų būti ịvardyti esminiai metų veiklos ataskaitos trūkumai.

Dokumentų tekstuose bibliotekų tikslai ir (ar) uždaviniai retoje SVB siejami su konkrečiu socialiniu turiniu, daugiausia dèmesio sutelkiama $\mathfrak{i}$ vidinę bibliotekos (sistemos) plètrą; todèl susidaro įspūdis, jog analizuojami pasiekimai ir pokyčiai reikšmingi ir svarbūs tik pačiai organizacijai.

Be to, dokumentu jzžangos tekstuose biblioteku veiklos tikslai ir $u z ̌ d a v i n i a i ~ t i k s l i a i$ ir aiškiai įvardijami itin retai. Dažniausiai tikslai apskritai neformuluojami arba formuluojami nekonkrečiai. Dar rečiau pagrindžiamas tų tikslų ir uždavinių aktualumas, susiejant juos su pagrindinèmis 
šalies, regiono ar konkrečios savivaldybès sprendžiamomis socialinėmis, ekonominėmis ar kultūrinėmis problemomis, kurios yra (ar gali būti) sprendžiamos dalyvaujant viešosioms bibliotekoms, realiais aptarnaujamos bendruomenès poreikiais. Formuluojant aptariamos veiklos tikslus ir uždavinius ataskaitose tiesiog pakartojamos pagrindiniuose veiklos dokumentuose nustatytos bibliotekų funkcijos (pvz., „universalaus dokumentu fondo sudarymas“, „teritorijos rašytinio paveldo kaupimas, saugojimas ir sklaida“, „bibliotekos paslaugu teikimas“ ir pan.). Kadangi pagrindinès bibliotekos funkcijos iš esmès nekinta arba kinta lètai, šiuo pagrindu įvardijami tikslai ir uždaviniai kartojasi metai iš metu; be to, neretai labai sunku nustatyti, kurios iš išvardytų veiklų laikomos tikslais, kurios - uždaviniais. Metų veiklos ataskaitų negalima laikyti užbaigtu informaciniu produktu - analitiniu dokumentu - dèl šiu priežasčių:

- Analitinio informacijos apdorojimo kokybè prasta arba labai prasta. Vyrauja aprašomojo pobūdžio informacija, taikomas ne galutiniu veiklos rezultatu, o procesų vertinimo modelis. Todèl beveik kiekvienu atveju visus tyrinètus dokumentus galime vertinti kaip neapdorotą informacijos masyvą, kuriame surinkti duomenys neịvertinti, dažnai apsiribojama tik faktų konstatavimu, pokyčiai fiksuojami tik pateikiant statistinius duomenis, kurie nekomentuojami ir nevertinami; labai paplitęs palyginimo veiksmas, tačiau retai atskleidžiama ilgesnio laikotarpio (1-5 metu) dinamika.

- Kiekviena veiklos sritis analizuojama autonomiškai, analizès duomenys nesiejami su visuma. Ir nors naudojami ịvairūs duomenys, jų pateikiama daug ir paprastai parengiami dideli darbai (vidutiniškai apie 50 puslapiu, dokumentų apimtis svyruoja nuo 13 iki 107 puslapiu), duomenų analizè yra paviršutiniška, informacija nesuvaldyta ir nesusisteminta, duomenys pernelyg detalizuoti, neanalizuojami svarbūs ryšiai tarp skirtingų kintamujų pateikta informacija kartojasi.

- Daug perteklinès informacijos analizuojant visas veiklos sritis, ypač vartotojų aptarnavimo, fondo sudarymo klausimus, kur gausus 
informacijos masyvas dažnai visiškai nesusistemintas ir nesutvarkytas. Metodinè veikla ar mokslo tiriamoji veikla dažniausiai pristatoma aprašomojo pobūdžio informacija ir vienu kitu neinformatyviu rodikliu. Duomenys, pristatantys mokslo tiriamąją veiklą, apskritai nefiksuojami arba fiksuojami retai, veikla išvis neaptariama ir neanalizuojama. Žmogiškujjų išteklių, finansavimo srities rodikliai neanalizuojami, nekomentuojami ir nevertinami.

- Atskirų veiklos sričių analizė beveik niekada nesusiejama su bibliotekos iggvendinamais uždaviniais ir tikslais, pokyčiai tik įvardijami, tačiau nei įvardijamos, nei aiškinamos tų pokyčių priežastys: nenustatyti priežastiniai ryšiai, neatskleisti analizuojamos sistemos ir jos sudedamųu dą dių funkcionavimo ir prognozavimo modeliai leidžia tvirtinti, kad šiuose dokumentuose nèra patikimos informacijos nei apie dabartinę analizuojamo objekto būklę, nei apie galimus sistemos ar atskirų jos dalių funkcionavimo pokyčius.

- Pasiekti rezultatai apibendrinami ir aptariami itin retai, dažniau išvardijami išoriniai veiksniai, dèl kurių vyksta vieni ar kiti procesai, darantys neigiamą ịtaką biblioteku veiklai (pvz., nepakankamas finansavimas, mažèjantis gyventojų, o kartu ir bibliotekos paslaugu naudotojų skaičius ir t. t.), dar rečiau pristatomos pagrindinès veiklos tendencijos ar nustatytos „siaurosios vietos“, spręstinos problemos, pateikiama jų raidos perspektyva ar galimi sprendimo variantai. Problemų sprendimo būdai (tais retais atvejais, kai jie atskleidžiami) dažniausiai suformuluoti kaip siekiamybe ir ịvardijami terminais „tobulinti“, „gerinti“, „plètoti“ ir pan.

Isvados tyrinejjamuose darbuose formuluojamos tiksliau ir profesionaliau nei tikslai ir uždaviniai (ižanginė dokumento dalis), tačiau šios abi ataskaitos dalys retai susiejamos tarpusavyjenet ir tuo atveju, kai tikslai ir uždaviniai konkrečiame darbe nurodyti. Išvados rengiamos nesusistemintu, išblaškytu, atsitiktinai parinktų faktų pagrindu; todèl analizès rezultatai yra neveiksmingi, nepagrịsti nei statistinių duomenų analize, nei tyrimų rezultatais, 
neretai apskritai prieštarauja atskirose ataskaitos dalyse pateiktiems rodikliams. Tad ir šioje ataskaitų dalyje teiginiai grindžiami ne faktais, o nuomonėmis, paprastai aptariamos ir ịvardijamos pasekmès, o ne jų priežastys.

Išsamesni tyrinejjimai ir vadovų bei darbuotojų apklausos duomenys atskleidè, kad šio klausimo sprendimai (jei būtų sprendžiama iš esmès) nebus paprasti. Ir darbuotojai, ir vadovai teigia, jog, jų vertinimu, šis dokumentas gali būti tinkama priemonè aiškintis sistemos veiklos pasiekimus ar spręstinas problemas, juo būtų galima remtis modeliuojant bibliotekos veiklos strategiją, o ir šio dokumento rengejjams pakanka specialiųų žinių ir kompetencijų, kad dokumentas atitiktų jam keliamus kokybės reikalavimus. Abi tyrimo dalyvių grupès labiau pritaria nuomonei, kad iš esmès nereikètų keisti nei metų veiklos ataskaitos formos, nei jos rengimo metodikos, tačiau sutinka su tuo, jog daliniai pokyčiai rengiant informacinius analitinius dokumentus sektoriuje reikalingi.

\subsection{Mokslo tiriamosios veiklos reikšmingumo ir vadovų bei darbuotojų galimybių dalyvauti tiriamojoje veikloje vertinimas}

Apklausos duomenys leidžia teigti, kad iš dalies ir bibliotekų vadovai, o dar dažniau bibliotekų darbuotojai turi tam tikrų abejonių dèl mokslo tiriamosios veiklos reikšmingumo ir jos teikiamos naudos SVB sektoriuje. Mokslo tiriamosios veiklos svarbą SVB pripažįsta 92,9 proc. visų anketinëje apklausoje dalyvavusių bibliotekų vadovų: 27 , arba 64,3 proc. $(\mathrm{N}=43)$ dalyvių teigè, kad jie tvirtai laikosi pozityvaus požiūrio, dar trečdalis (12, arba 28,6 proc.) pažymëjo, jog mokslo tiriamoji veikla šiame sektoriuje gana svarbi („labiau svarbi nei ne“). Tik nedaug apklausos dalyviu (3, arba 7,1 proc. vadovu) dèl šios veiklos pareiškẻ labiau neigiamą nei teigiamą nuostatą. Kategoriškai neigiamai dèl mokslo tiriamosios veiklos nepasakè né vienas iš tyrime dalyvavusių SVB direktorių. Vadovai dažniau rinkosi pozityvaus turinio atsakymus ir vertindami šios veiklos naudingumą; tačiau teikdami tikslesnius vertinimus teikiamą naudą įvertino ne pačiu aukščiausiu balu (3,9 balo pagal 5 balų sistema). 
Tai, kad tiriamoji veikla bibliotekose, kuriose dirba tyrimo dalyviai, laikoma intelektualia ir reikšminga, tvirtai teige penktadalis (18,4 proc.) visų apklausoje dalyvavusių darbuotojų $(\mathrm{N}=349)$. Daugiau nei pusè (53,6 proc.) darbuotojų tvirtos nuomonès neturèjo, tačiau vis dèlto nemažai jų (40,9 proc.) turëjo pozityvią nuostatą (,labiau taip nei ne“). Palyginti nemažai (25,1 proc.) teigè apskritai ị šį klausimą negalintys atsakyti.

Panašiai pasiskirsto ir darbuotojų atsakymai ị klausimą „Ar, Jūsų nuomone, tiriamosios veiklos kompetencija yra neatsiejama Jūsų profesinès kompetencijos dalis?" (23 pav.). Tvirtai tuo ịsitikinę trečdalis tyrimo dalyviu, tvirtos nuomonès neturi (atsakymai „labiau taip nei ne“ ir „labiau ne nei taip“) didesnè pusè (63,2 proc.) informantų. Išsamesnè šių duomenu analizė parodè, kad tvirtą pozityvią nuostatą išsakè CB personalas, dažniausiai direktoriaus pavaduotojo, funkcinio struktūrinio padalinio vadovo, funkcinio padalinio vyriausiojo ar vyresniojo specialisto (metodininko, bibliotekininko) pareigas einantys darbuotojai. Tačiau tvirtai teigiamai atsakiusiu grupeje yra ir 27 (25,2 proc., $\mathrm{N}=107)$ kaimo teritorijoje veikiančių struktūrinių padalinių darbuotojai.

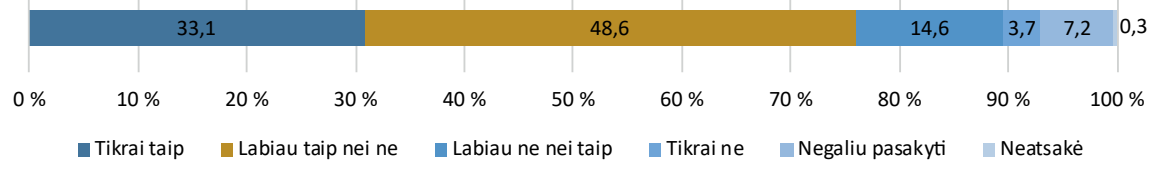

23 pav. Tiriamosios veiklos kompetencijos vertinimas (darbuotoju grupei)

Paprašyti pateikti konkrečių tiriamosios veiklos poveikio bibliotekų veiklai pavyzdžiu, jos naudą ir realius rezultatus galëjo įvardyti didesnè pusè (28, arba 65,1 proc.) vadovu, kiti tvirtino, kad tokios naudos nemato ir jokiu pavyzdžiu pateikti negali. Tačiau čia svarbūs ir gana reikšmingą vietą vadovų pažiūrų sistemoje užimantys neigiami mokslo tiriamosios veiklos ir jos rezultatu panaudojimo biblioteku praktikoje vertinimai. Tyrimo rezultatai rodo, kad praktinès patirties naudą labiau nei mokslinių tyrimų ar analizės reikšmę vertina 32 iš 43 , arba 74,4 proc. tyrime dalyvavę 
aukščiausio rango bibliotekų vadovai, ir tik 7 , arba 16,3 proc., šiam teiginiui labiau nepritaria, negu pritaria, o visiškai jam nepritariančiu vadovų grupëje nèra né vieno.

Taigi šiuos rezultatus turètume vertinti nevienareikšmiškai. Logiška būtų manyti, kad deklaruodami mokslo tiriamosios veiklos teorinę reikšmę, jos svarbą bibliotekoms ir jų įsitvirtinimui socialinèse struktūrose, plečiant žinojimo ribas bibliotekų teorijos ir praktikos srityse, biblioteku vadovai šios veiklos naudą vertina atsargiai. Jos naudingumą praktiniame kiekvienos bibliotekos gyvenime santūriai vertina ir biblioteku personalas.

Kliūčiu, trukdančių organizuoti ir vykdyti mokslo tiriamąją veiklą SVB, yra nemažai ir, vadovų nuomone, jos visos kiek labiau nei vidutiniškai svarbios (vidutinis vertinimas $-3,4$ balo pagal 5 balų sistema) (24 pav.). Svarbiausios iš jų - didelis darbuotojų darbo krūvis kitose srityse; personalui nepakanka tiriamosios veiklos kompetenciju; stokojama informacijos ir žinių apie visame bibliotekų sektoriuje atliekamus tyrinejjimus; sunku įrodyti tiriamosios veiklos reikalingumą bibliotekos savininkui (visos priežastys įvertintos 3,9 balo pagal 5 balų sistema).

Mažiausią įtaką šiai veiklai daro tokie veiksniai kaip aukščiausio rango vadovų teorinių žinių stoka tiriamosios veiklos organizavimo ir vykdymo klausimais, informacijos ir žinių pasirenkant aktualias tyrinèjimų sritis SVB sistemoje trūkumas (abi priežastys po 3,2 balo pagal 5 balu sistema). Beveik tokiu pat balu ịvertintas ir bibliotekos vadovu bazinių gebëjimų ir žinių trūkumas tiriamosios veiklos organizavimo ir vykdymo klausimais bei informacijos ir žinių apie viešujų biblioteku sektoriuje atliekamus tyrinejjimus (abi priežastys - po 3,3 balo pagal 5 balu sistema). Kitaip tariant, vadovai tik iš dalies sieja, o dažniausiai ir visiškai nesieja mokslo tiriamosios veiklos nei su savo šios srities kompetencijomis (kaip teigè vienas apklausos dalyvis: „Moksliniais darbais turètų užsiimti atskiras bibliotekos specialistas, o ne vadovas. Vadovas gali tik koordinuoti tyrimą. "), nei su tiriamosios veiklos kontekstu pačioje savivaldybès viešojoje bibliotekoje, taip pat ir visame viešųjų bibliotekų sektoriuje. 
Šie duomenys leidžia daryti prielaidą, kad, vadovų manymu, nei pačiose SVB, nei visame viešujų bibliotekų sektoriuje nesunku pasirinkti tyrinëjimų sritis, susivokti bendrame tiriamosios veiklos kontekste ar pasisemti patirties.

Darbuotojai situaciją vertina labai panašiai, tačiau kiek drąsiau nei vadovai teigia, jog labiausiai ju galimybes dalyvauti mokslo tiriamojoje veikloje riboja praktinių igūdžiu stoka (15,6 proc. visų pasirinkimų, $\mathrm{N}=980$ ), didelis pagrindinio darbo krūvis (15,4 proc. visų pasirinkimų, $\mathrm{N}=980)$ ir laiko stoka (14,7 proc. visų pasirinkimų, $\mathrm{N}=980)$ (57 pav.).

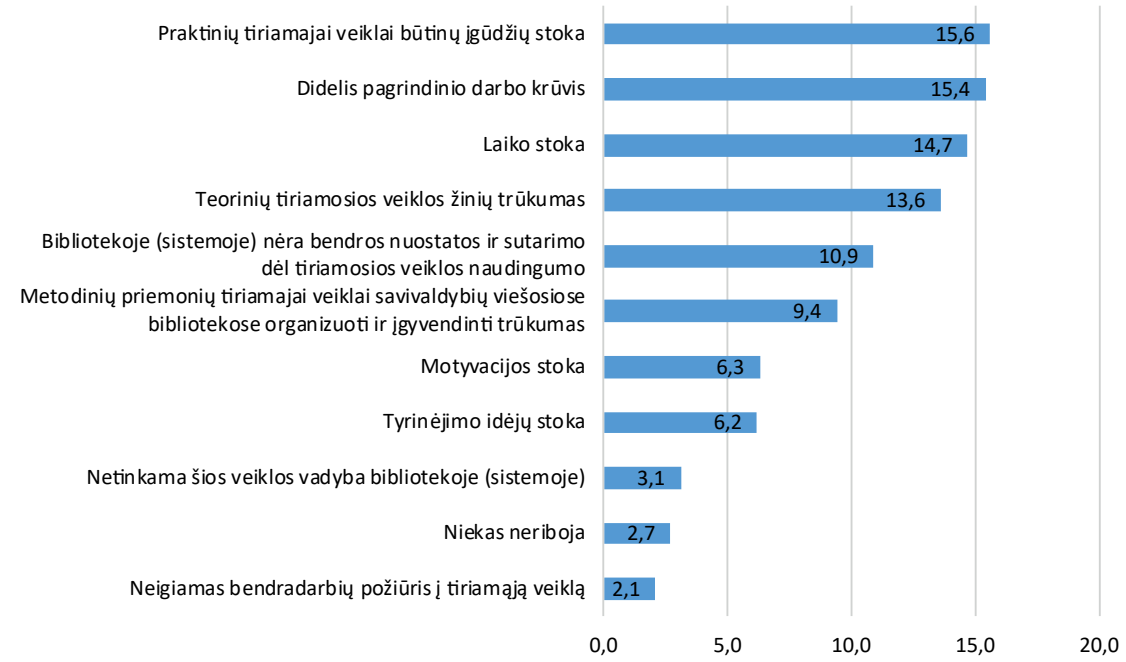

24 pav. Priežastys, ribojančios darbuotoju dalyvavima tiriamojoje veikloje

Verta atkreipti dèmesį, kad darbuotojų vertinimuose kliūtimi laikomas ne tik teorinių žinių trūkumas (13,6 proc. visų pasirinkimų, $\mathrm{N}=980$ ), bet ir bendros nuostatos bei sutarimo dèl tiriamosios veiklos naudingumo pačioje bibliotekoje stoka (10,9 proc. visų pasirinkimų, $\mathrm{N}=980$ ). Tokios priežastys kaip motyvacijos stoka, tyrinëjimo idèjų stoka ar netinkama mokslo tiriamosios veiklos vadyba sistemoje, darbuotoju nuomone, nèra didžiausios kliūtys plètoti šią veiklą.

Dèl šios veiklos institucionalizavimo SVB sektoriaus struktūrose bibliotekų vadovų nuomonė nèra gana aiški: vertinant kiekybiniu požiūriu, 
tik kiek daugiau nei pusė vadovų pritaria tam, kad sektoriaus bibliotekose turètų būti atliekami ir moksliniai, ir rinkos tyrimai, ir informaciniai analitiniai darbai $(25$ pav.).

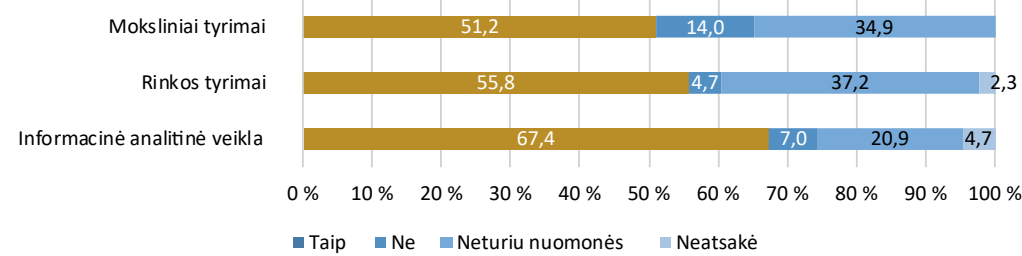

25 pav. Vadovu nuomone dèl galimybiu vykdyti mokslo tiriamaja veikla SVB

Dèl mokslinių tyrimų - nè vienas SVB vadovas nepatvirtino, kad „visiškai pritaria“ pozicijai, jog taikomuosius mokslinius tyrimus SVB galètų atlikti savarankiškai. Tam, kad bibliotekose būtų savarankiškai atliekami rinkos tyrimai, kategoriškai „taip“ pasakè tik vienas bibliotekos vadovas. Reikšdami nuomonę ir dèl mokslinių tyrimų, ir dèl rinkos tyrimų bibliotekų vadovai dažniausiai rinkosi poziciją (4,6 reitingo balo pagal 5 balų sistema), kad moksliniai tyrimai turètų būti atliekami konkrečios SVB bazèje, tačiau organizuoti ir atlikti juos turètų institucijos, kurių personalas turi šiai veiklai būtinas kompetencijas. Mažiau populiari (3,6 reitingo balo pagal 5 balų sistema) yra galimybè atliekant mokslinius tyrimus bendradarbiauti su kitomis institucijomis: iš anketoje siūlomų bendradarbių ši informantų grupe būtų linkusi rinktis LNB specialistus (3,9 reitingo balo iš 5), kiek rečiau - apskričių viešųjų biblioteku specialistus (3,6 reitingo balo iš 5) ir dar rečiau - aukštąsias mokyklas (2,8 reitingo balo iš 5$)$.

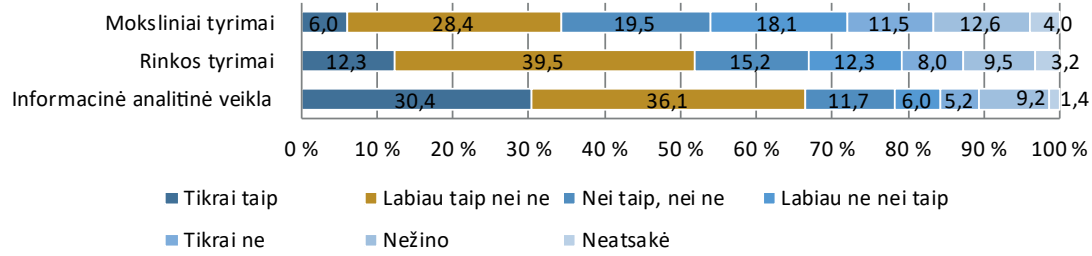

26 pav. Darbuotojų nuomonè dèl galimybiu atlikti mokslo tiriamaja veikla SVB 
Dauguma darbuotoju kaip ir vadovai nèra susidarę tvirtos nuomonès dèl mokslo tiriamosios veiklos institucionalizavimo. Vertindami bendriausiu aspektu galètume sakyti, kad tam tikra dalis SVB dirbančiu specialistų mano, jos visos mokslo tiriamosios veiklos kryptys turètų rasti vietą SVB veiklų struktūrose (26 pav.); mažiausiai darbuotojų (6,0 proc.) tvirtai pritaria tam, kad SVB turètų būti atliekami moksliniai tyrimai, kiek daugiau jų (12,3 proc.) buvo už rinkos tyrimų atlikimą SVB ir daugiausia (30,4 proc.) pritarè tam, kad bibliotekose būtų sistemingai ir planingai atliekami informaciniai analitiniai darbai.

Neigiamą nuomonę šiuo klausimu dažniau pareiškẻ VB struktūrinių padalinių (skyriu) vadovai ir juose dirbantys specialistai, t. y. tie darbuotojai, kuriems dažniausiai ir pavedami konkretūs tokio pobūdžio darbai. Pozityviausią nuomonę dèl tokių veiklų pareiškè SVB teritoriniuose struktūriniuose padaliniuose dirbantys darbuotojai, tam pritaria ir palyginti nedaug aukščiausio rango (direktorių pavaduotojų) pareigas einančių specialistų.

Pastebèta, kad darbuotojų nuostatos šiais klausimais glaudžiausiai siejasi su jų ǐssimokslinimu ir igytu kvalifikacijos laipsniu: kuo naujesnes (laiko atžvilgiu) studiju programas yra baigę SVB darbuotojai, tuo pozityviau jie vertina SVB galimybes dalyvauti visose šiose veiklose. Mažiausiai „entuziazmo“ šiuo požiūriu turi aukštesnijji išsimokslinimą igiję darbuotojai; šiam tiriamosios grupès dalyvių pogrupiui būdinga ir tai, kad palyginti daug darbuotojų neigiamas nuostatas pareiškè ir dèl mokslinių tyrimų (35,0 proc.), ir dèl rinkos tyrimų (39,3 proc.), ir dèl informacinès analitinès $(38,9$ proc.) veiklos. Galètume taip pat teigti, jog pozityvus ar negatyvus požiūris ị mokslo (tiriamosios) veiklos integravimo į SVB veiklų struktūras nedaug priklauso nuo darbuotojų studijuotų mokslų sričių, tačiau reikia pastebėti, jog labiau negatyviai nei pozityviai šiais klausimais nusiteikę bibliotekininkystės, informacijos ir komunikacijos studijų programas baigę specialistai.

Svarbiausios priemonès, darbuotojų nuomone, galinčios padèti îtvirtinti ir plètoti tiriamąją veiklą viešosiose bibliotekose, yra specialistų 
kompetencija (tinkamas specialistų parengimas ir (arba) efektyvi metodinè pagalba) ir tinkamas atlygis už šią veiklą (piniginè paskata už šios veiklos rezultatus) (27 pav.). Kiti veiksniai - bibliotekos vadovų požiūris, korporatyvinio pobūdžio bendradarbiavimas, veiklos rezultatų viešinimas, o kartu ir galimybė pasidalyti atliktų (ar atliekamu) tyrimų rezultatais - šiuo požiūriu laikomi gerokai mažiau reikšmingais veiksniais.

Menkiausią poveikį, darbuotojų nuomone, turètų ryšiu ir bendradarbiavimo su aukštosiomis mokyklomis stiprinimas (35, arba 3,2 proc. visų pasirinkimu).

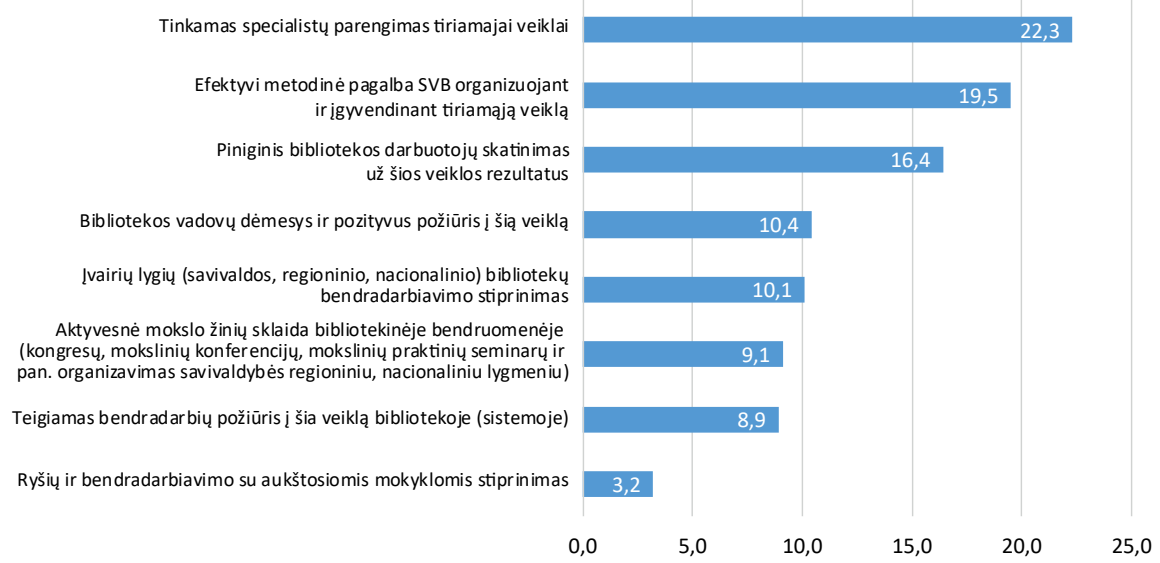

27 pav. Priemoniu, kurios padetu îtvirtinti ir pletoti mokslo tiriamaja veikla viešuju biblioteku sektoriuje, pasiskirstymas darbuotoju grupes atsakymuose

\section{IŠVADOS}

1. Tyrimo rezultatai atskleide, kad SVB sektoriuje terminai, semantiškai susiję su mokslo tiriamąja veikla ir 3 pagrindinèmis jos kryptimis (moksliniais tyrimais, rinkos tyrimais ir (ar) informacine analitine veikla), įrašyti bent viename iš absoliučios daugumos SVB (98,3 proc.) veiklą reglamentuojančių dokumentų. Tačiau terminijos ịteisinimo, veiklos integravimo ị bendruosius mokslo tiriamosios veiklos kontekstus ir su šia veikla siejamas socialines struktūras būklè prasta: nepagrịstas dokumentuose 
vartojamų terminų variantiškumas, jie vartojami pramaišiui, aiškiau neišskiriamos ir tiksliau neapibrěziamos atskiros šios veiklos kryptys. Ir veiklos reglamentavimas, ir jos dokumentavimas sektoriaus bibliotekose nesistemiškas, daug neapibrèžtumų ir spragų.

2. SVB sektoriuje mokslo tiriamosios veiklos institucionalizavimas yra menkas ir tai skiria viešąsias bibliotekas nuo kitų institucijų, dalyvaujančiu mokslo tiriamojoje veikloje. Vadybiniai sprendimai, susiję su šios veiklos organizavimu, planavimu, vadovavimu ir kontrole sektoriaus bibliotekose, yra fragmentuoti ir negali užtikrinti nẻ vienos iš šios veiklos krypčių (nei mokslinių tyrimu, nei rinkos tyrimu, o iš dalies ir informacinès analitinès veiklos) planingumo, sistemingumo ir kryptingumo. Nè vienoje sektoriaus SVB mokslo tiriamoji veikla nedokumentuojama kaip atskira, savarankiška veiklos sritis, procesai neišskiriami iš kitų bibliotekos veiklos srautų. Mažesneje sektoriaus dalyje (45,0 proc.) ši veikla reglamentuota sistemingiau ir nuosekliau, tačiau ir tose SVB, kuriose galima įžvelgti šių procesų organizacinių modelių apraiškas, struktūros susiformavusios stichiškai, veikla reglamentuojama kaip šalutine, papildoma šalia pagrindinių funkcijų (paslaugų organizavimo ir teikimo, valdymo ir kt.) ir SVB struktūrinių padalinių, ir pareigybių lygmeniu.

3. SVB sektoriuje daugiau nei trečdalis personalo (34,6 proc. visu sektoriaus darbuotoju) ipareigojama veikti mokslo tiriamojoje veikloje ir toks pavedimas ịrašytas biblioteku veiklos dokumentuose. Tokị ịpareigojimą paprastai nulemia einamos pareigos, neatsižvelgiant arba tik iš dalies atsižvelgiant ị konkretaus darbuotojo kvalifikacijas ir kompetencijas tiriamojoje veikloje. Šioje srityje veikiančio personalo struktūra viešųjų biblioteku sektoriuje labai îvairi, o dauguma personalo neturi sisteminio pasirengimo ir kvalifikacijų, reikalingu šiai veiklai; struktūra yra negyvybinga, inertiška ir turi daug formalioms struktūroms būdingų bruožų. Beveik visai šiai specialistų grupei reikšmingesnis poreikis igyti šios srities bazinių žinių ir kompetencijų, o ne žinių atnaujinimo (perkvalifikavimo) poreikis mokslo tiriamosios veiklos srityje. 
4. SVB sektoriaus veiklos laukas 2010-2015 m. laikotarpiu buvo tyrinëjamas gana intensyviai. Visų institucijų atliktų tyrinëjimų skaičius kiekviename regione skirtingas. Remdamiesi turimais duomenimis (ne visos SVB buvo įtrauktos i tyrinëjimus, ne visos SVB teikè duomenis apie ju teritorijoje vykdytus darbus), galime teigti, kad vidutiniškai vieno regiono SVB veiklos lauke per metus buvo atliekami 7-8 įvairaus lygmens, didesnio ar mažesnio dydžio ir reikšmès tyrinëjimai, kuriuose vienaip ar kitaip (kaip tyrimo objektai arba ir kaip tyrimo dalyvès) buvo itrauktos ir SVB.

Iš visų atliktų tyrinejjimų šiame lauke du kartus dažniau (120 tyrinèjimu, arba 65,9 proc., $\mathrm{N}=182$ ) tiriamuosius darbus inicijavo, organizavo ir atliko išorès institucijos; beveik pusę jų ( 57 , arba 47,5 proc., $\mathrm{N}=120$ ) inicijavo ir atliko korporatyvinès institucijos - LNB, AVB iniciatyva ir pajègomis.

5. Sektoriuje neapibrèžta, kurios temos turètų priklausyti bibliotekininkystès ir informacijos sričiai ir konkrečiam SVB sektoriaus tyrinëjimų laukui. Sektoriuje nèra jokių esminių susitarimų dèl tyrinèjimo sričių, pagrindinių tyrinètinų dalykinių problemų. Išorès institucijų atlikti tyrimai sektoriaus veiklos lauke visu pirma skirti organizaciniams sprendimams pagrịsti, tiriant sektoriaus biblioteku poveikį, jų veiklos aplinkas, biblioteku administravimo klausimus, teikiamas paslaugas, ju poreiki ir pasitenkinimo jomis vertinimus. Savarankiškai atliktų tyrinëjimų temu analizės duomenys rodo, kad sektoriuje dažniausiai orientuojamasi i savo poreikius ir intencijas ir menkai atsižvelgiama arba neatsižvelgiama i platesnes problemas, kurias būtina spręsti visai profesinei bendruomenei. Dèl to stebima didelè temu fragmentacija, vyrauja smulkūs tyrimai. Mažai dèmesio skiriama ir nėra aiškios informacijos apie nesinaudojančiu bibliotekų paslaugomis gyventoju poreikius; SVB nèra pajègumų profesionaliai ištyrinèti objektus, ypač surinkti visą rinkodarinę informaciją apie bibliotekų paslaugų vartotojus pagal atskiras vartotojų kategorijas ir nišas, kuriose veikia kiti kultūros lauko veikejjai. 
6. Savarankiškas SVB indèlis ị tiriamąją veiklą sektoriuje palyginti kuklus (34,1 proc. visų sektoriuje atliktų darbu). Didžiausią jų dali sudaro rinkos tyrimams priskirtini darbai, taip pat darbai, skirti vadybiniams sprendimams pagristi, kitaip tariant, darbai, kuriems atlikti reikalingesnès vadybininko nei tyrèjo kompetencijos. Nors bibliotekų teikiamų paslaugu (jų poreikio, kokybès ir pasitenkinimo paslaugomis) tyrinëjimai labiausiai paplitę SVB savarankiškai atliekamų tyrimų grupeje (29 darbai, arba 44,6 proc. visų šia tema atliktų tyrinëjimų, $\mathrm{N}=65$ ), didesnè savarankiškai atliktų tiriamojo pobūdžio darbų (apklausų, analizių, vertinimų) dalis sektoriuje nedokumentuota, o dokumentuoti darbai retai atitinka šiam žanrui keliamus reikalavimus. Šie tyrinëjimai nesistemingi, atspindi situaciją nedidelèje teritorijos dalyje, jų rezultatai įforminti nekokybiškai ir dažnai jau neprieinami, nes nearchyvuojami, neviešinami ir nesaugomi. Dèl šiu priežasčiu jie gali būti naudingi tik tai konkrečiai bibliotekai (ar sistemai), kurios veiklos lauko objektai buvo tyrinëjami.

Mègèjiškas šių tyrinëjimų lygis, menka tyrimų kokybè (netinkamai surinkti, nepakankami, netikslūs duomenys, iki minimumo supaprastinta tyrinëjimų metodika ir pan. trūkumai) mažina ne tik tiriamosios veiklos efektyvumą, bet dažnai kenkia ir pačioms bibliotekoms: prasta tyrimų kokybè reiškia, kad nenustatomos realios bibliotekos veiklos problemos, o parengti pasiūlymai (jei jie rengiami) neatitinka realiu poreikių, taigi ir vadybiniai ar technologiniai sprendimai tampa nepatikimi.

7. SVB rengiamos metu veiklos ataskaitos, kurios tyrimo kontekste buvo vertinamos kaip analitinès informacijos krypčiai priskiriami darbai, neatitinka informacinio analitinio žanro reikalavimų ir jų negalima laikyti užbaigtu analitiniu dokumentu. Tyrimu nustatytas didelis atotrūkis tarp šių darbų vertinimų, kuriuos pateikia patys dokumentų autoriai ir jų vadovai, ir vertinimu, kuriuos teikia išorès ekspertai (apskričių viešųjų bibliotekų specialistai), vertinantys darbus pagal bendrai parengtus ir analitiniam darbui taikomus vertinimo kriterijus. Tokio vertinimų skirtumo priežastys galètų būti paaiškinamos tik abiejų pusių konkrečiam dokumentui (arba 
jo žanrui) taikomų kokybės kriterijų nesuderinamumu arba, tikètina, tam tikra SVB atstovų, dalyvavusių tyrime, gynybine pozicija.

8. Mokslo tiriamosios veiklos, kaip ir atskiru jos krypčių, naudą pozityviai vertina, jos svarbą ir reikšmę sektoriaus raidai pripažǐsta ir biblioteku vadovai, ir sektoriaus darbuotojai. Net 81,7 proc. tyrime dalyvavusiu darbuotoju pritaria nuomonei, kad tiriamosios veiklos kompetencijos yra neatsiejama ju profesinès kompetencijos dalis.

Tačiau abiejų apklausoje dalyvavusių grupių atsakymuose dèl galimybès savarankiškai, pačių SVB pajègomis vykdyti mokslo tiriamąją veiklą ir (ar) atskiras šios veiklos kryptis SVB ryškiausi neapsisprendimo požymiai. Ir vadovu, ir darbuotojų grupeje dèl visų tiriamosios veiklos krypčiu vyrauja lankstūs, neapibrèžti vertinimai („labiau gerai negu blogai“ ir „labiau blogai negu gerai“) arba atsisakoma vertinti („neturiu nuomonès“). Kadangi juos pasirenka didžioji dauguma tyrimo dalyviu, galime manyti, kad ir vadovams, ir darbuotojams trūksta patikimų įrodymų (faktų, statistinių duomenu, asmeninès patirties) tvirtesnems nuostatoms susidaryti. Kartu tai netiesiogiai patvirtina prielaidą, jog šio profesinio neapsisprendimo priežastys turètu būti siejamos ne tik su nepakankamomis šios srities žiniomis SVB sektoriuje, bet ir tokių žinių trūkumu aukštesnio lygmens korporatyvinèse struktūrose.

Taigi atliekant tyrimą gautus rezultatus galètume vertinti nevienareikšmiškai ir teigti, kad deklaruodami mokslo tiriamosios veiklos teorinę reikšmę, jos svarbą bibliotekoms ir joms įsitvirtinti socialinèse struktūrose, plečiant žinojimo ribas bibliotekų teorijos ir praktikos srityse, dauguma vadovu nemato sektoriaus biblioteku kaip šios veiklos organizatoriu ir savarankiškų vykdytojų. Jie labiau pritartų veiklos modeliui, kai šios srities intelektiniai sprendimai ir igyvendinimo praktika būtų sutelkti stambesnėse korporatyvinèse struktūrose, pirmenybę atiduodami LNB, iš dalies sutikdami bendradarbiauti su apskričių viešosiomis bibliotekomis, tačiau išbraukdami iš galimų partnerių sąrašo aukštąsias mokyklas.

Atsargiai šios veiklos naudingumą praktiniame kiekvienos bibliotekos gyvenime vertina ir bibliotekų personalas. 


\section{REKOMENDACIJOS}

Apibendrinant tyrimo rezultatus svarbu pastebèti, kad SVB sektoriuje mokslo tiriamoji veikla apima ịvairias šios veiklos kryptis ir primena mozaiką, iš kurios elementų sudèlioti vientisą paveikslą nèra paprasta. Dar svarbiau, kad sektoriaus bibliotekos neturi veiklos gairių, kuriomis galètu vadovautis. Būtų logiška manyti, kad pravartu aptarti ir sukurti efektyvesnị šios veiklos modeli, optimaliau organizuoti, integruoti ir koordinuoti mokslo tiriamają veiklą ir sektoriaus, ir apskritai viso bibliotekų tinklo struktūrose.

Tam reikètų:

- aptarti ir suformuluoti bendrą požiūrị i terminus ir jų prasmes, metodus ir tyrinëjamas idejas ir intencijas; apibrěžti ir atskirti bibliotekoms ir jų veiklos laukui priskirtinas sritis ir posritis; susitarti dèl mokslo tiriamosios veiklos standartų, leidžiančių integruoti bibliotekose atliekamus mokslinius tyrimus, rinkos tyrimus ir informacinius analitinius darbus ị bendrą mokslo tiriamosios veiklos kontekstą;

- suformuluoti tyrimų strategiją bibliotekų sektoriuje (įtraukiant ir aukštąsias mokyklas), nustatyti prioritetus susiejant su atskiru sektorių biblioteku veiklos aktualijomis; sukurti proceso analizès ir stebėsenos, poveikio vertinimo sistemą, sukuriant galimybes efektyviai valdyti procesą ir atskiruose sektoriuose, ir visame biblioteku tinkle;

- nustačius mokslinių tyrimų poreikį, profesionaliai orientuotus tyrimus ir temas sutelkti aukštosiose mokyklose ir aukštesnio lygmens korporatyvinèse struktūrose (LNB ir AVB) ir taip sudaryti sąlygas ne tik aukštesnio lygmens mokslo tiriamosios veiklos institucionalizacijai, bet kartu ir aktualiems tyrimams ir platesnèms problemu formuluotèms;

- SVB susitelkti į rinkos tyrimus ir personalo informacinių analitinių gebëjimų stiprinimą, užtikrinantị atliekamų darbų kokybę; atskirose bibliotekose plètoti tas sritis, kurios jau turi didesnị įdirbị. 


\section{Literatūra}

1. CHIVERS, Barbara; THEBRIDGE, Stella. Best value in public libraries: the role of research: Research paper [interaktyvus]. 2000. [Žiūrèta 2018 m. rugsëjo 8 d.]. Interneto prieiga: https://www.emeraldinsight.com/doi/full/10.1108/01435120010347928

2. DRYŽAITÉ, Ieva; VALAITYTĖ, Asta. Viešuju biblioteku tiriamoji veikla. Kauno apskrities viešosios bibliotekos atliktas koordinuotasis tyrimas: [tyrimo ataskaita, mašinraštis]. Kaunas: Kauno apskrities viešoji biblioteka, 2017, 70 p.

3. FARMER, Lesley; STRICEVIC, Ivanka. Using research to promote literacy and reading in libraries: guidelines for librarians [interaktyvus]. IFLA Headquarters, 2011.28 p. (IFLA Professional Reports: 125) [žiūrèta $2018 \mathrm{~m}$. birželio 19 d.]. Interneto prieiga: https:// www.ifla.org/files/assets/hq/publications/professional-report/125.pdf. ISBN 978-9077897-48-5; ISSN 0168-1931.

4. Frascati vadovas. Mokslinès ir technologinès veiklos matavimas. Standartinè praktika siūloma mokslinių tyrimų ir eksperimentinès plètros statistiniams tyrimams [interaktyvus]. Vilnius: Eugrimas, 2007. 285 p. [Žiūrèta 2017 m. spalio 16 d.]. Interneto prieiga: https://books.google.lt/books?id=-Or9p2gUsjMC\&pg=PA249\&lpg=PA249\&dq=Mok slin\%C4\%97+tiriamoji+veikla+terminas\&source=bl\&ots=4tYgO-BDGz\&sig=eDg1aL lH4WxUU0yqI0WPRCgBE8g\&hl=lt\&sa=X\&ved=0ahUKEwjA44m4uaDaAhVBQZ oKHTpsBzk4ChDoAQhFMAY\#v=onepage\&q=Mokslin\%C4\%97\%20tiriamoji\%20 veikla\%20terminas\&f=false. ISBN 978-9955-682-68-4.

5. Frascati vadovas 2015: Mokslinių tyrimų ir eksperimentinès plètros duomenų rinkimo bei teikimo rekomendacijos. Mokslinès, technologinès ir inovacinès veiklos vertinimas (lietuviškas leidimas). Vilnius, Lietuvos inovacijų centras, 2017, 377 p. [Žiūrèta 2017 m. spalio 13 d.]. Interneto prieiga: http://lic.lt/wp-content/uploads/2017/09/Frascativadovas-2015-1.pdf

6. GIRNIENĖ, Irmina. Tyrimo „Panevėżio regiono savivaldybiu viešuju biblioteku mokslo (tiriamoji) veikla 2010-2015 metais" ataskaita [mašinraštis]. Panevėžys: Panevė̌io apskrities Gabrielès Petkevičaitès-Bitès viešoji biblioteka, 2017, 69 p.

7. GOODALL, Deborah. Research activities and UK public libraries: past imperfect, future tense?" [interaktyvus]. Library Management, Vol. 19 Iss: 8, 1998, p. 459-468. [Žiūrèta 2017 m. lapkričio 27 d.]. Interneto prieiga: https://www.emeraldinsight.com/doi/ full/10.1108/01435129810239958

8. GRICIŪTĖ, Laima. Analizuojame savo darbą. Šiandien aktualu, 1994, I pusm., p. 8-10.

9. GRICIŪTÉ, Laima. Ataskaita - konstravimas ar analizè. Šiandien aktualu, 1990, II pusm., p. 3-5.

10. JASKONIENĖ, Dalia. Tekstine bibliotekos veiklos ataskaita [rankraštis]. 2003. 14 p.

11. KLIVIS, Edgaras. Atvirojo kodo kultūra ir dalyvaujamasis posūkis: šiuolaikinès kultūros komunikacijos probleminė analizé [interaktyvus] Iš: CITVARIENĖ Daiva, et al. Komunikuoti kultürą: institucijos, strategijos, auditorijos. kolektyvinè monografija. Vytauto Didžiojo universitetas, 2015, p. 85-132. [Žiūrèta 2018 m. birželio 15 d.]. Interneto prieiga: http://www.vdu.lt/ wp-content/uploads/2016/03/2015_Monografija_Komunikuoti-kultura.pdf

12. KVIETKAUSKIENĖ, Rimalda. Bibliotekos veiklos plano ir ataskaitos sąsajos. Šiandien aktualu, 2013, Nr. 2(49). P. 95-120. 
13. KVIETKAUSKIENĖ, Rimalda. Kaip parengti metinę tekstinę darbo ataskaitą. Šiandien aktualu, 1997, I pusm. P. 3-17.

14. KVIETKAUSKIENĖ, Rimalda. Svarbiausi savivaldybių viešųjų bibliotekų veiklos planavimo aspektai. Šiandien aktualu, 2009, Nr. 1(40). P. 7-41.

15. Lietuvos Respublikos biblioteku ịstatymas [interaktyvus]. Valstybès žinios, 1995, Nr. 51-1245. [Žiūrèta $2017 \mathrm{~m}$. lapkričio 27 d.]. Interneto prieiga [galiojanti suvestinė redakcija]: https://www.e-tar.lt/portal/lt/legalAct/TAR.5A04D7CC7EF6/klBUTNoriX

16. McCLURE, Charles R.; BISHOP, Ann. The Status of Research in Library IInformation Science: guarded optimism [interaktyvus]. 1989, 17 p. [Žiūrèta 2018 m. rugsèjo 7 d.]. Interneto prieiga: https://www.ideals.illinois.edu/bitstream/handle/2142/41248/crl_50_02_ 127_opt.pdf?sequence

17. PALIUKAITĖ-MEDECKIENĖ, Rita. Alytaus ir Vilniaus apskričin savivaldybiu viešuju biblioteku mokslo (tiriamoji) veikla 2010-2015 metais: tyrimo ataskaita [interaktyvus]. Vilnius: Vilniaus apskrities Adomo Mickevičiaus viešoji biblioteka, 2017, 109 p. [Žiūrèta $2017 \mathrm{~m}$. gruodžio $12 \mathrm{~d}$.]. Interneto prieiga: http://amb.lt/regionas/lt/http-ambregiono. virtualu.lt-lt-tyrimai-ir-analizes-tyrimai-metais-73?c-12/t-18

18. POCIUS, Arūnas; OKUNEVIČIŪTĖ-NEVERAUSKIENĖ, Laima. Tikslinių grupių integracijos ị darbo rinką galimybių vertinimas. Iš: Lietuvos socialine raida. Užimtumo politikos ir socialines pagalbos įtaka socialinei stratifikacijai [interaktyvus] 2015, Nr. 4, p. 38-58. [Žiūrèta 2017 m. spalio 16 d.]. Interneto prieiga: http://lstc.lt/download/ Lietuvos_socialine_raida_2015_visas.pdf

19. ROCHESTER, Maxine K. Library and information science research in Australia 19851994: A content analysis of research articles in the Australian Library Journal and Australian Academic \& Research Libraries [interaktyvus] Library Journal and Australian Academic $\&$ Research Libraries, 2017, p. 207-214. [Žiūrèta 2018 m. rugsejo 7 d.]. Interneto prieiga: https://www.tandfonline.com/doi/full/10.1080/00048623.2016.1253424

20. SKUODYTĖ, Elvyda. Moksliniai tyrimai bibliotekose: probleminiai aspektai. Šiandien aktualu, 2015, Nr. 1(52). P. 74-94.

21. SKUODYTE, Elvyda. Moksliniai tyrimai bibliotekose: probleminiai aspektai (pabaiga). Šiandien aktualu, 2016, Nr. 1(54). P. 121-148.

22. SKUODYTĖ, Elvyda. Moksliniai tyrimai bibliotekose: probleminiai aspektai [interaktyvus]. Šiandien aktualu, 2017, Nr. 1(56). P. 206-237. Interneto prieiga: https://drive. google.com/file/d/0B_-73IZKEJy5ZmM1TTg0Ul81QXc/view

23. SKUODYTÉ, Elvyda. Taikomojo mokslo tiriamojo darbo ataskaita: rekomendacijos. Šandien aktualu, 2014, Nr. 2(51). P. 167-198.

24. SKUODYTĖ, Elvyda. Rekomendacijos: koordinuotasis tyrimas „Savivaldybių viešųjų bibliotekų mokslo tiriamoji veikla 2010-2015 metais" [mašinraštis]. Vilnius: Lietuvos nac. M. Mažvydo biblioteka, 2016. 5 p. [42].

25. SPRINDŽIUKAITĖ, Paulina. Savivaldybiu viešuju biblioteku mokslinè (tiriamoji) veikla 2010-2015 metais: [tyrimo ataskaita, mašinraštis]. Šiauliai: Šiaulių apskrities Povilo Višinskio viešoji biblioteka, 2017, 67 p.

26. VOLSKYTĖ, Ieva. Koordinuotojo tyrimo „Savivaldybiu viešuju biblioteku tiriamoji veikla 2010-2015 metais" Klaipedos ir Tauragés apskričiu savivaldybiu viešuju biblioteku ataskaita [mašinraštis]. Klaipèda: Ievos Simonaitytès Klaipèdos apskrities viešoji biblioteka, 2017, 42 p. 


\title{
RESEARCH ACTIVITIES AT MUNICIPAL PUBLIC LIBRARIES IN 2010-2015
}

\author{
SUMMARY OF THE COORDINATED STUDY
}

Scientific studies and their various forms and especially research activities and innovations present one of the principal policies of the European Union, which have the purpose to acquire reliable tools within every field of activities enabling responsible actions and ensuring the transformation of innovative ideas into marketable products andlor services improving the people's lives and contributing to resolving both urgent and enduring issues of communities.

Research activities at municipal public libraries have never been a subject of special study. But the fact is that these libraries, as well as other institutions, are affected by changes in their internal and external environment, which are difficult to predict; it is often argued that their objectives are not explicitly declared and that the results of their performance are hard to measure. It is common opinion that, in comparison with other library systems, this sector undergoes less research of trends in the development of their performance and experiences fewer management solutions based on research data and less control of the implementation of these solutions as well as less assessment of the impact of various factors and evaluation of the achievements. The information received by applying research methods is not treated as a source for making solutions, and there is neither practical experience in forecasting tendencies nor employing methods of social modelling for this purpose.

The objective of this study is to investigate the situation with research activities within the sector of municipal public libraries and find out if there 
is any intellectual expertise involved in generating new knowledge andlor applying it in library performance.

The results of the study show that there is no reliable agreement regarding neither the issues related to the terminology of these activities nor those related to content and procedures. Though the sector's activities are rather intensely investigated, the contribution of municipal public libraries to this investigation is modest, and the level of the institutionalization of these activities is low. A major part of research work done at these libraries is not documented, and the documented efforts rarely conform to the requirements for this genre. The research tools are not applied for identifying actual problems within library performance and the proposed solutions do not match actual needs of the libraries, and, for that matter, management or technological solutions that ensue from the research become unreliable.

The results of the study explicitly show that the sector lacks both research and analytical competence. The structural potential of libraries is either not controlled or controlled insufficiently. It is observed that there is no conformity between provisions declared in operational documents and actually performed tasks as well as a wide gap between the evaluation done by authors of informative analytical products of the sector (annual reports) and those done by their executives as well as external experts.

When declaring the theoretical significance of research work and its importance for libraries and their entrenchment within social structures, a majority of executives of municipal public libraries, as well as some of their staff, do not treat these libraries as organizers and independent agents of this work. They choose a model when intellectual solutions in this field and their practical implementation are concentrated within larger cooperative structures with the preference of the Martynas Mažvydas National Library of Lithuania and, to some extent, of county public libraries. The category of major partners within this research activity does not include higher education establishments. 


\section{MOKSLO TIRIAMOSIOS VEIKLOS SAMPRATA, JOS IDENTIFIKAVIMAS N APSKRIČIŲ SAVIVALDYBIŲ VIEŠŲJŲ BIBLIOTEKŲ TEISĖS AKTUOSE}

\begin{tabular}{|c|c|c|c|}
\hline $\begin{array}{l}\text { SVB pava- } \\
\text { dinimas }\end{array}$ & $\begin{array}{l}\text { Dokumen- } \\
\text { tas }\end{array}$ & $\begin{array}{c}\text { Cituojamo teiginio } \\
\text { numeris ir cituoja- } \\
\text { mas teiginys }\end{array}$ & $\begin{array}{c}\text { Cituojamas šaltinis } \\
\text { (šaltinio bibliografinis aprašas) }\end{array}$ \\
\hline $\begin{array}{l}\text { ELEK- } \\
\text { TRÉNŲ } \\
\text { SVB }\end{array}$ & $\begin{array}{l}\text { Elektrėnų } \\
\text { savivaldybės } \\
\text { viešosios } \\
\text { bibliotekos } \\
\text { nuostatai }\end{array}$ & $\begin{array}{l}\text { 15.12. Nuolat tiria } \\
\text { gyventoju poreikius, } \\
\text { susijusius su bibliote- } \\
\text { kos veikla ir, atsižvelg- } \\
\text { dama ị rezultatus, } \\
\text { tobulina Bibliotekos } \\
\text { veiklą. }\end{array}$ & $\begin{array}{l}\text { Elektrènų savivaldybės viešosios biblio- } \\
\text { tekos nuostatai: patvirtinta Elektrènu } \\
\text { savivaldybės tarybos } 2014 \mathrm{~m} \text {. gegužès } \\
28 \mathrm{~d} \text {. sprendimu Nr. TS-139 [interakty- } \\
\text { vus]. Elektrènai, } 2014 \text {. [6 p.]. [Žiūrèta } \\
2016 \mathrm{~m} \text {. balandžio } 20 \mathrm{~d} \text {.]. Interneto } \\
\text { prieiga: http://www.elektrenai.mvb.lt/ } \\
\text { images/ESVB/veiklos_atsakaita/nuosta- } \\
\text { tai.pdf }\end{array}$ \\
\hline $\begin{array}{l}\text { IGNALI- } \\
\text { NOS r. } \\
\text { SVB }\end{array}$ & $\begin{array}{l}\text { Ignalinos } \\
\text { rajono sa- } \\
\text { vivaldybès } \\
\text { viešosios } \\
\text { bibliotekos } \\
\text { nuostatai }\end{array}$ & $\begin{array}{l}\text { 12.9. rinkos tyrimas } \\
\text { ir viešosios nuomo- } \\
\text { nés apklausa, kodas } \\
73.20 \text {. }\end{array}$ & $\begin{array}{l}\text { Ignalinos rajono savivaldybès viešosios } \\
\text { bibliotekos nuostatai: patvirtinta Ignali- } \\
\text { nos rajono savivaldybés tarybos } 2013 \mathrm{~m} \text {. } \\
\text { vasario } 14 \mathrm{~d} \text {. sprendimu Nr. T-22 [in- } \\
\text { teraktyvus]. Ignalina, } 2013 \text {. [Žiūrèta } \\
2016 \mathrm{~m} \text {. balandžio } 20 \mathrm{~d} \text {.]. Interneto } \\
\text { prieiga: http://195.182.92.232/vaktai/ } \\
\text { Default.aspx?Id=3\&DocId=17900 }\end{array}$ \\
\hline $\begin{array}{l}\text { IGNALI- } \\
\text { NOS r. } \\
\text { SVB }\end{array}$ & $\begin{array}{l}\text { Ignalinos } \\
\text { rajono sa- } \\
\text { vivaldybés } \\
\text { viešosios } \\
\text { bibliotekos } \\
\text { nuostatai }\end{array}$ & $\begin{array}{l}\text { 15.8. Nuolat ir siste- } \\
\text { mingai tiria gyventoju } \\
\text { naudojimosi bib- } \\
\text { lioteka ir jos teikia- } \\
\text { momis paslaugomis } \\
\text { poreikius, tobulina } \\
\text { Bibliotekos darbą. }\end{array}$ & $\begin{array}{l}\text { Ignalinos rajono savivaldybės viešosios } \\
\text { bibliotekos nuostatai: patvirtinta Ignali- } \\
\text { nos rajono savivaldybės tarybos } 2013 \mathrm{~m} \text {. } \\
\text { vasario } 14 \mathrm{~d} \text {. sprendimu Nr. T-22 [in- } \\
\text { teraktyvus]. Ignalina, } 2013 \text {. [Žiūrèta } \\
2016 \mathrm{~m} \text {. balandžio } 20 \mathrm{~d} \text {.]. Interneto } \\
\text { prieiga: http://195.182.92.232/vaktai/ } \\
\text { Default.aspx?Id=3\&DocId=17900 }\end{array}$ \\
\hline $\begin{array}{l}\text { RASEI- } \\
\text { NIUU r. } \\
\text { SVB }\end{array}$ & $\begin{array}{l}\text { Raseinių } \\
\text { rajono sa- } \\
\text { vivaldybès } \\
\text { viešosios } \\
\text { bibliotekos } \\
\text { skaitytojų } \\
\text { aptarnavi- } \\
\text { mo skyriaus } \\
\text { nuostatai }\end{array}$ & $\begin{array}{l}\text { 8.22. vykdyti sociali- } \\
\text { nius ir kitus tyrimus, } \\
\text { kuriu rezultatai rei- } \\
\text { kalingi bibliotekos } \\
\text { veiklai tobulinti, opti- } \\
\text { maliau komplektuoti } \\
\text { dokumentu fonda, } \\
\text { tenkinti vartotojų } \\
\text { poreikius ir pan. }\end{array}$ & $\begin{array}{l}\text { Raseinių rajono savivaldybès viešosios } \\
\text { bibliotekos skaitytojų aptarnavimo sky- } \\
\text { riaus nuostatai: patvirtinta Raseinių r. } \\
\text { SVB direktoriaus 2010-06-28 įsakymu } \\
\text { Nr. } 58 \text { [interaktyvus]. Raseiniai, } 2010 \text {. } \\
\text { [Žiūreta } 2016 \text { m. balandžio } 20 \text { d.] Inter- } \\
\text { neto prieiga: http://www.raseiniai.rvb. } \\
\text { lt/images/galleries/kiti/skaitytoju\%20 } \\
\text { aptarnavimo\%20sk\%20nuostatai.pdf }\end{array}$ \\
\hline
\end{tabular}




\begin{tabular}{|c|c|c|c|}
\hline $\begin{array}{l}\text { SVB pava- } \\
\text { dinimas }\end{array}$ & $\begin{array}{l}\text { Dokumen- } \\
\quad \text { tas }\end{array}$ & $\begin{array}{c}\text { Cituojamo teiginio } \\
\text { numeris ir cituoja- } \\
\text { mas teiginys }\end{array}$ & $\begin{array}{c}\text { Cituojamas šaltinis } \\
\text { (šaltinio bibliografinis aprašas) }\end{array}$ \\
\hline $\begin{array}{l}\text { RASEI- } \\
\text { NIŲ r. } \\
\text { SVB }\end{array}$ & $\begin{array}{l}\text { Raseinių } \\
\text { rajono sa- } \\
\text { vivaldybès } \\
\text { viešosios } \\
\text { bibliotekos } \\
\text { informacijos } \\
\text { skyriaus } \\
\text { nuostatai }\end{array}$ & $\begin{array}{l}\text { 9.13. vykdyti vartoto- } \\
\text { ju poreikių ir kitus ty- } \\
\text { rimus, kuriu rezultatai } \\
\text { reikalingi skyriaus } \\
\text { veiklai tobulinti. }\end{array}$ & $\begin{array}{l}\text { Raseinių rajono savivaldybės viešo- } \\
\text { sios bibliotekos informacijos skyriaus } \\
\text { nuostatai: patvirtinta Raseinių r. SVB } \\
\text { direktoriaus } 2010-06-28 \text { įsakymu Nr. } 58 \\
\text { [interaktyvus]. Raseiniai, 2010. [Žiūrèta } \\
2016 \mathrm{~m} \text {. balandžio } 20 \mathrm{~d} \text {.]. Interneto } \\
\text { prieiga: http://www.raseiniai.rvb.lt/ima- } \\
\text { ges/galleries/kiti/informacijos\%20sk\%20 } \\
\text { nuostatai.pdf }\end{array}$ \\
\hline $\begin{array}{l}\text { RASEI- } \\
\text { NIUU r. } \\
\text { SVB }\end{array}$ & $\begin{array}{l}\text { Raseinių } \\
\text { rajono sa- } \\
\text { vivaldybės } \\
\text { viešosios } \\
\text { bibliotekos } \\
\text { vaikų li- } \\
\text { teratūros } \\
\text { skyriaus } \\
\text { nuostatai }\end{array}$ & $\begin{array}{l}\text { 10.15.vykdyti rinko- } \\
\text { daros, socialinius ir } \\
\text { kitus tyrimus, kurių } \\
\text { rezultatai reikalingi } \\
\text { vaikų literatūros sky- } \\
\text { riaus veiklai tobulinti, } \\
\text { optimaliau komplek- } \\
\text { tuoti dokumentų fon- } \\
\text { dą, tenkinti vartotojų } \\
\text { poreikius ir pan. }\end{array}$ & $\begin{array}{l}\text { Raseinių rajono savivaldybės viešosios } \\
\text { bibliotekos skaitytojų vaikų literatūros } \\
\text { skyriaus nuostatai: patvirtinta Raseiniu r. } \\
\text { SVB direktoriaus } 2010-06-28 \text { isakymu } \\
\text { Nr. } 58 \text { [interaktyvus]. Raseiniai, } 2010 \text {. } \\
\text { [Žiūrèta } 2016 \text { m. balandžio } 20 \text { d.]. } \\
\text { Interneto prieiga: http://www.raseiniai. } \\
\text { rvb.lt/images/raseini\%20rajono\%20savi- } \\
\text { valdybs\%20vieosios\%20bibliotekos\%20 } \\
\text { vaiku\%20literaturos\%20skyriaus\%20 } \\
\text { nuostatai.pdf }\end{array}$ \\
\hline
\end{tabular}




\section{MOKSLO TIRIAMOSIOS IR INFORMACINĖS ANALITINĖS VEIKLOS ORGANIZAVIMAS N APSKRIČIŲ SAVIVALDYBIŲ VIEŠOSIOSE BIBLIOTEKOSE (FUNKCIJŲ PASKIRSTYMAS)}

\begin{tabular}{|c|c|c|c|c|c|c|c|c|c|c|c|c|}
\hline \multirow[b]{2}{*}{$\begin{array}{l}\text { Eil. } \\
\text { Nr. }\end{array}$} & \multirow{2}{*}{$\begin{array}{l}\text { Ra- } \\
\text { jono, } \\
\text { miesto } \\
\text { SVB } \\
\text { pavadi- } \\
\text { nimas }\end{array}$} & \multirow[b]{2}{*}{$\begin{array}{l}\text { Struktūrinių padalinių } \\
\text { grupes }\end{array}$} & \multicolumn{2}{|c|}{ Iš ju } & \multicolumn{7}{|c|}{$\begin{array}{l}\text { Moksliniams tyrimams priskiriamų funkciju } \\
\text { paskirstymas }\end{array}$} & \multirow{2}{*}{$\begin{array}{c}\text { Informacinei } \\
\text { analitinei veiklai } \\
\text { priskiriamu funk- } \\
\text { ciju paskirstymas } \\
\\
\text { ipareigojimai**** }\end{array}$} \\
\hline & & & $\begin{array}{l}\text { struktūrinio pada- } \\
\text { linio pavadinimas } \\
\text { (ịrašomas taip, kaip } \\
\text { rašomas bibliotekos } \\
\text { dokumentuose) }\end{array}$ & $\begin{array}{l}\text { pareigybès } \\
\text { pavadinimas }\end{array}$ & $\begin{array}{c}\text { or- } \\
\text { gani- } \\
\text { zuo- } \\
\text { ja }\end{array}$ & $\begin{array}{l}\text { ko- } \\
\text { ordi- } \\
\text { nuoja }\end{array}$ & $\begin{array}{l}\text { at- } \\
\text { sa- } \\
\text { ko }\end{array}$ & $\begin{array}{c}\text { daly- } \\
\text { vauja }\end{array}$ & $\begin{array}{c}\text { vyk- } \\
\text { do } \\
\text { (ti- } \\
\text { ria) }\end{array}$ & $\begin{array}{c}\text { or- } \\
\text { gani- } \\
\text { zuoja } \\
\text { grupes }\end{array}$ & $\begin{array}{l}\text { kito- } \\
\text { kie } \\
\text { ipa- } \\
\text { reigo- } \\
\text { jimai } \\
\text { ji*** }\end{array}$ & \\
\hline 1. & A SVB & Administracija & & & $x$ & $x$ & $x$ & $x$ & $x$ & $x$ & & \\
\hline & A SVB & & & & & & & & & & & \\
\hline & A SVB & $\begin{array}{l}\text { Struktūriniams padaliniams } \\
\text { nepriskirti specialistai* }\end{array}$ & * & $\begin{array}{l}\text { Kultūrinès } \\
\text { veiklos vadybi- } \\
\text { ninkas }\end{array}$ & $x$ & $x$ & $x$ & $x$ & $x$ & & & \\
\hline & A SVB & & & $\begin{array}{l}\text { Viešujų ryšių } \\
\text { specialistas }\end{array}$ & $x$ & $x$ & $x$ & $x$ & $x$ & & & \\
\hline & A SVB & $\begin{array}{l}\text { Ištekliu sudarymo ir IPS } \\
\text { kūrimo sektorius** }\end{array}$ & $\begin{array}{l}\text { Dokumentų kom- } \\
\text { plektavimo skyrius }\end{array}$ & $\begin{array}{l}\text { Skyriaus ve- } \\
\text { dëjas }\end{array}$ & $x$ & $x$ & $x$ & $x$ & $x$ & & & \\
\hline & A SVB & & & $\begin{array}{l}\text { Vyresnysis bi- } \\
\text { bliotekininkas }\end{array}$ & $x$ & $x$ & $x$ & $x$ & $x$ & & & \\
\hline & A SVB & $\begin{array}{l}\text { Bibliografinès (informaci- } \\
\text { nès) veiklos sektorius }{ }^{* *}\end{array}$ & $\begin{array}{l}\text { Informacijos ir } \\
\text { kraštotyros skyrius }\end{array}$ & $\begin{array}{l}\text { Skyriaus ve- } \\
\text { dèjas }\end{array}$ & $x$ & $x$ & $x$ & $x$ & $x$ & & & \\
\hline & A SVB & & $\begin{array}{l}\text { Informacijos ir } \\
\text { kraštotyros skyrius }\end{array}$ & $\begin{array}{l}\text { Vyresnysis bi- } \\
\text { bliotekininkas }\end{array}$ & $x$ & $x$ & $x$ & $x$ & $x$ & & & \\
\hline
\end{tabular}




\begin{tabular}{|c|c|c|c|c|c|c|c|c|c|c|c|c|}
\hline \multirow[b]{2}{*}{$\begin{array}{l}\text { Eil. } \\
\text { Nr. }\end{array}$} & \multirow{2}{*}{$\begin{array}{l}\text { Ra- } \\
\text { jono, } \\
\text { miesto } \\
\text { SVB } \\
\text { pavadi- } \\
\text { nimas }\end{array}$} & \multirow[b]{2}{*}{$\begin{array}{l}\text { Struktūrinių padalinių } \\
\text { grupès }\end{array}$} & \multicolumn{2}{|c|}{ Iš ju } & \multicolumn{7}{|c|}{$\begin{array}{l}\text { Moksliniams tyrimams priskiriamų funkciju } \\
\text { paskirstymas }\end{array}$} & \multirow{2}{*}{$\begin{array}{c}\text { Informacinei } \\
\text { analitinei veiklai } \\
\text { priskiriamu funk- } \\
\text { ciju paskirstymas }\end{array}$} \\
\hline & & & $\begin{array}{c}\text { struktūrinio pada- } \\
\text { linio pavadinimas } \\
\text { (įrašomas taip, kaip } \\
\text { rašomas bibliotekos } \\
\text { dokumentuose) }\end{array}$ & $\begin{array}{l}\text { pareigybès } \\
\text { pavadinimas }\end{array}$ & $\begin{array}{l}\text { or- } \\
\text { gani- } \\
\text { zuo- } \\
\text { ja }\end{array}$ & $\begin{array}{l}\text { ko- } \\
\text { ordi- } \\
\text { nuoja }\end{array}$ & $\begin{array}{l}\text { at- } \\
\text { sa- } \\
\text { ko }\end{array}$ & $\begin{array}{l}\text { daly- } \\
\text { vauja }\end{array}$ & $\begin{array}{l}\text { vyk- } \\
\text { do } \\
\text { (ti- } \\
\text { ria) }\end{array}$ & $\begin{array}{c}\text { or- } \\
\text { gani- } \\
\text { zuoja } \\
\text { grupes }\end{array}$ & $\begin{array}{l}\text { kito- } \\
\text { kie } \\
\text { ipa- } \\
\text { reigo- } \\
\text { jimai } \\
* * * *\end{array}$ & \\
\hline & A SVB & $\begin{array}{l}\text { Suaugusiujų gyventojų } \\
\text { aptarnavimo sektoriuje }^{* *}\end{array}$ & $\begin{array}{l}\text { Suaugusiuju aptar- } \\
\text { navimo skyrius }\end{array}$ & $\begin{array}{l}\text { Skyriaus ve- } \\
\text { dëjas }\end{array}$ & $x$ & $x$ & $x$ & $x$ & $x$ & & & \\
\hline & A SVB & $\begin{array}{l}\text { Vaikų aptarnavimo sekto- } \\
\text { riuje** }\end{array}$ & $\begin{array}{l}\text { Vaikų literatūros } \\
\text { skyrius }\end{array}$ & $\begin{array}{l}\text { Skyriaus ve- } \\
\text { dëjas }\end{array}$ & $x$ & $x$ & $x$ & $x$ & $x$ & & & \\
\hline & A SVB & $\begin{array}{l}\text { Kituose struktūriniuose } \\
\text { padaliniuose }\end{array}$ & Metodikos skyrius & $\begin{array}{l}\text { Vyresnysis } \\
\text { metodininkas }\end{array}$ & $x$ & $x$ & $x$ & $x$ & $x$ & & & \\
\hline & Iš viso & & 5 & 10 & 10 & 10 & 10 & 10 & 10 & 1 & & \\
\hline 2. & B SVB & Administracija & Nèra & & & & & & & & & \\
\hline & B SVB & & & & & & & & & & & \\
\hline & B SVB & $\begin{array}{l}\text { Struktūriniams padaliniams } \\
\text { nepriskirti specialistai* }\end{array}$ & Nèra & & & & & & & & & \\
\hline & B SVB & \begin{tabular}{|l|l} 
Išteklių sudarymo ir IPS \\
kūrimo sektorius**
\end{tabular} & $\begin{array}{l}\text { Spaudiniu kom- } \\
\text { plektavimo skyrius }\end{array}$ & $\begin{array}{l}\text { Skyriaus ve- } \\
\text { déjas }\end{array}$ & & & & & $x$ & & & \\
\hline & B SVB & & $\begin{array}{l}\text { Spaudiniu kom- } \\
\text { plektavimo skyrius }\end{array}$ & $\begin{array}{l}\text { Vyresnysis bi- } \\
\text { bliotekininkas }\end{array}$ & & & & & & & & $\begin{array}{l}\text { Analizuoja do- } \\
\text { kumentų fondo } \\
\text { būklę ir teikia } \\
\text { pasiūlymus dèl jos } \\
\text { pagerinimo }\end{array}$ \\
\hline
\end{tabular}




\begin{tabular}{|c|c|c|c|c|c|c|c|c|c|c|c|c|}
\hline \multirow[b]{2}{*}{$\begin{array}{l}\text { Eil. } \\
\text { Nr. }\end{array}$} & \multirow{2}{*}{$\begin{array}{l}\text { Ra- } \\
\text { jono, } \\
\text { miesto } \\
\text { SVB } \\
\text { pavadi- } \\
\text { nimas }\end{array}$} & \multirow[b]{2}{*}{$\begin{array}{l}\text { Struktūrinių padalinių } \\
\text { grupes }\end{array}$} & \multicolumn{2}{|c|}{ Iš ju } & \multicolumn{7}{|c|}{$\begin{array}{l}\text { Moksliniams tyrimams priskiriamų funkcijų } \\
\text { paskirstymas }\end{array}$} & \multirow{2}{*}{$\begin{array}{c}\text { Informacinei } \\
\text { analitinei veiklai } \\
\text { priskiriamų funk- } \\
\text { cijų paskirstymas } \\
\\
\text { ipareigojimai**** }\end{array}$} \\
\hline & & & $\begin{array}{l}\text { struktūrinio pada- } \\
\text { linio pavadinimas } \\
\text { (įrašomas taip, kaip } \\
\text { rašomas bibliotekos } \\
\text { dokumentuose) }\end{array}$ & $\begin{array}{l}\text { pareigybès } \\
\text { pavadinimas }\end{array}$ & $\begin{array}{c}\text { or- } \\
\text { gani- } \\
\text { zuo- } \\
\text { ja }\end{array}$ & $\begin{array}{c}\text { ko- } \\
\text { ordi- } \\
\text { nuoja }\end{array}$ & $\begin{array}{l}\text { at- } \\
\text { sa- } \\
\text { ko }\end{array}$ & $\begin{array}{l}\text { daly- } \\
\text { vauja }\end{array}$ & $\begin{array}{l}\text { vyk- } \\
\text { do } \\
\text { (ti- } \\
\text { ria) }\end{array}$ & $\begin{array}{c}\text { or- } \\
\text { gani- } \\
\text { zuoja } \\
\text { grupes }\end{array}$ & $\begin{array}{l}\text { kito- } \\
\text { kie } \\
\text { ipa- } \\
\text { reigo- } \\
\text { jimai } \\
* * * *\end{array}$ & \\
\hline & B SVB & $\begin{array}{l}\text { Bibliografinès (informaci- } \\
\text { nès) veiklos sektorius ** }\end{array}$ & & & & & & & & & & \\
\hline & B SVB & $\begin{array}{l}\text { Suaugusiuju gyventojų } \\
\text { aptarnavimo sektoriuje }\end{array}$ & & & & & & & & & & \\
\hline & B SVB & $\begin{array}{l}\text { Vaiku aptarnavimo sekto- } \\
\text { riuje** }\end{array}$ & $\begin{array}{l}\text { Vaikų literatūros } \\
\text { skyrius }\end{array}$ & $\begin{array}{l}\text { Skyriaus ve- } \\
\text { dèjas }\end{array}$ & & & & & $x$ & & & \\
\hline & B SVB & $\begin{array}{l}\text { Kituose struktūriniuose } \\
\text { padaliniuose } \\
\text { p** }\end{array}$ & Metodikos skyrius & $\begin{array}{l}\text { Vyresnysis } \\
\text { metodininkas }\end{array}$ & & & & & $x$ & & & \\
\hline & Iš viso & & 3 & 4 & 0 & 0 & 0 & 0 & 3 & & & 1 \\
\hline 3. & C SVB & & & & & & & & & & & \\
\hline & .......... & & & & & & & & & & & \\
\hline
\end{tabular}

* Struktūriniams padaliniams nepriskirti specialistai - tai pareigybès, pavaldžios tiesiogiai bibliotekos vadovui, pavyzdžiui, kai kuriose bibliotekose viešujų ryšių specialistas, kultūrinès veiklos vadybininkas ar pan.

** Sektoriui šioje lentelèje priskiriami praktikoje įvairiais pavadinimais ịvardijami SVB struktūriniai padaliniai, veikiantys konkrečioje iš lentelèje išvardytų veiklos sričių; dèl didelès struktūrinių padalinių pavadinimų ìvairovès lentelèse rekomenduojama struktūrinių padalinių pavadinimus rašyti tiksliai ịvardijant autentišką struktūrinio padalinio pavadinimą.

*** Jeigu SVB teritorinių padalinių (filialu) pareigybèms taip pat nustatyti reikalavimai dalyvauti ar vykdyti tiriamają veiklą, reikètų tiksliai išsiaiškinti tokių filialų skaičių ir čia ji irašyti. Jei tai tik dalis filialu, juos reikètų išvardyti, jei visi SVB filialai - pakanka parašyti jų skaičių.

**** Rekomenduojama surašyti tikslias citatas, nes tokių ịpareigojimų ịvairovẻ yra didelè; aprašomajame tekste šiuos teiginius reikètų apibendrinti ir ǐ̌samiau, nei paskirstyta lentelèje, suskirstyti ị atskiras, artimas pagal turinị grupes. 
MOKSLO TIRIAMOJOJE VEIKLOJE DALYVAUJANČIO PERSONALO CHARAKTERISTIKOS N APSKRIČIŲ SAVIVALDYBIŲ VIEŠOSIOSE BIBLIOTEKOSE

\begin{tabular}{|c|c|c|c|c|c|c|c|c|c|c|c|c|c|c|c|}
\hline \multirow{5}{*}{$\begin{array}{c}\text { SVB } \\
\text { pavadi- } \\
\text { nimas }\end{array}$} & \multirow{5}{*}{$\begin{array}{l}\text { Darbuo- } \\
\text { tojo darbo } \\
\text { vieta } \\
\text { (strukturri- } \\
\text { nis padali- } \\
\text { nys) }\end{array}$} & \multirow{5}{*}{ Pareigybè } & \multirow{5}{*}{$\begin{array}{c}\text { Darbuotojo } \\
\text { funkcijos } \\
\text { (organizuoja, } \\
\text { atsako, koordi- } \\
\text { nuoja, vykdo*, } \\
\text { dalyvauja** ir } \\
\text { pan.) }\end{array}$} & \multirow{5}{*}{$\begin{array}{c}\text { Skiria darbo } \\
\text { laiko*** } \\
\text { (1,00 VEE; } \\
0,50 \text { VEE; } \\
0,25 \text { VEE; } \\
<0,25 \text { VEE; } \\
\text { N) }\end{array}$} & \multicolumn{11}{|c|}{ Darbuotojo, šiuo metu einančio šias pareigas, duomenys } \\
\hline & & & & & \multicolumn{7}{|c|}{ išsimokslinimas $* * * * *$} & \multicolumn{3}{|c|}{$\begin{array}{c}\text { darbo stažas (pilni } \\
\text { metai) }\end{array}$} & \multirow{4}{*}{$\begin{array}{l}\text { am- } \\
\text { žius } \\
\text { (pilni } \\
\text { metai) }\end{array}$} \\
\hline & & & & & \multicolumn{2}{|c|}{ specialusis } & \multicolumn{5}{|c|}{ kitos srities } & \multirow{3}{*}{$\begin{array}{c}\text { iš viso } \\
\text { bibli- } \\
\text { oteki- } \\
\text { nis }\end{array}$} & \multirow{3}{*}{\begin{tabular}{|c|} 
šioje \\
bib- \\
liote- \\
koje
\end{tabular}} & \multirow{3}{*}{\begin{tabular}{|c|} 
einant \\
šias \\
parei- \\
gas
\end{tabular}} & \\
\hline & & & & & & aukš- & auk & štasis & aukštc & snysis & & & & & \\
\hline & & & & & $\begin{array}{c}\text { aukś- } \\
\text { tasis }\end{array}$ & $\begin{array}{c}\text { tes- } \\
\text { nysis }\end{array}$ & $\begin{array}{l}\text { laips- } \\
\text { nis }\end{array}$ & $\begin{array}{c}\text { sri- } \\
\text { tis }\end{array}$ & $\begin{array}{l}\text { laips- } \\
\text { nis }\end{array}$ & sritis & kitas & & & & \\
\hline A SVB & $\begin{array}{l}\text { Administ- } \\
\text { racija }\end{array}$ & $\begin{array}{l}\text { Direktoriaus } \\
\text { pavaduotojas }\end{array}$ & $\begin{array}{l}\text { Organizuoja, } \\
\text { koordinuoja } \\
\text { ir vykdo, } \\
\text { organizuoja } \\
\text { grupes }\end{array}$ & $\mathrm{N}$ & $\mathrm{M} /-95$ & & & & & & & & & & \\
\hline A SVB & & $\begin{array}{l}\text { Kultūrinès } \\
\text { veiklos vady- } \\
\text { bininkas }\end{array}$ & $\begin{array}{l}\text { Organizuoja, } \\
\text { koordinuoja } \\
\text { ir vykdo }\end{array}$ & $\mathrm{N}$ & & $S$ & & & & & & & & & \\
\hline A SVB & & $\begin{array}{l}\text { Viešụjų ryšiu } \\
\text { specialistas }\end{array}$ & $\begin{array}{l}\text { Organizuoja, } \\
\text { koordinuoja } \\
\text { ir vykdo }\end{array}$ & $\mathrm{N}$ & & & M & $\begin{array}{l}\text { Viešasis } \\
\text { admi- } \\
\text { nistra- } \\
\text { vimas } \\
\end{array}$ & & & & & & & \\
\hline \multicolumn{16}{|l|}{$\ldots \ldots}$. \\
\hline Iš viso & 5 & 10 & & $\mathrm{~N}$ & & & & & & & & Vidut. & Vidut. & Vidut. & Vidut. \\
\hline
\end{tabular}




\begin{tabular}{|c|c|c|c|c|c|c|c|c|c|c|c|c|c|c|c|}
\hline \multirow{5}{*}{$\begin{array}{c}\text { SVB } \\
\text { pavadi- } \\
\text { nimas }\end{array}$} & \multirow{5}{*}{$\begin{array}{l}\text { Darbuo- } \\
\text { tojo darbo } \\
\text { vieta } \\
\text { (struktūri- } \\
\text { nis padali- } \\
\text { nys) }\end{array}$} & \multirow{5}{*}{ Pareigybé } & \multirow{5}{*}{$\begin{array}{c}\text { Darbuotojo } \\
\text { funkcijos } \\
\text { (organizuoja, } \\
\text { atsako, koordi- } \\
\text { nuoja, vykdo*, } \\
\text { dalyvauja** ir } \\
\text { pan.) }\end{array}$} & \multirow{5}{*}{$\begin{array}{l}\text { Skiria darbo } \\
\text { laiko***: } \\
\text { (1,00 VEE; } \\
0,50 \mathrm{VEE} ; \\
0,25 \mathrm{VEE} ; \\
<0,25 \mathrm{VEE} ; \\
\mathrm{N})\end{array}$} & \multicolumn{11}{|c|}{ Darbuotojo, šiuo metu einančio šias pareigas, duomenys } \\
\hline & & & & & \multicolumn{7}{|c|}{ išsimokslinimas $* * * * *$} & \multicolumn{3}{|c|}{$\begin{array}{c}\text { darbo stažas (pilni } \\
\text { metai) }\end{array}$} & \multirow{4}{*}{$\begin{array}{l}\text { am- } \\
\text { žius } \\
\text { (pilni } \\
\text { metai) }\end{array}$} \\
\hline & & & & & \multicolumn{2}{|c|}{ specialusis } & \multicolumn{5}{|c|}{ kitos srities } & \multirow{3}{*}{$\begin{array}{c}\text { iš viso } \\
\text { bibli- } \\
\text { oteki- } \\
\text { nis }\end{array}$} & \multirow{3}{*}{$\begin{array}{l}\text { šioje } \\
\text { bib- } \\
\text { liote- } \\
\text { koje }\end{array}$} & \multirow{3}{*}{$\begin{array}{l}\text { einant } \\
\text { šias } \\
\text { parei- } \\
\text { gas }\end{array}$} & \\
\hline & & & & & \multirow[b]{2}{*}{$\begin{array}{c}\text { aukš- } \\
\text { tasis }\end{array}$} & \multirow{2}{*}{$\begin{array}{l}\text { aukš- } \\
\text { tes- } \\
\text { nysis }\end{array}$} & \multicolumn{2}{|c|}{ aukštasis } & \multicolumn{2}{|c|}{ aukštesnysis } & \multirow[b]{2}{*}{ kitas } & & & & \\
\hline & & & & & & & $\begin{array}{l}\text { laips- } \\
\text { nis }\end{array}$ & $\begin{array}{c}\text { sri- } \\
\text { tis }^{* * * *}\end{array}$ & $\begin{array}{l}\text { laips- } \\
\text { nis }\end{array}$ & sritis & & & & & \\
\hline $\begin{array}{c}\text { B } \\
\text { RSVB }\end{array}$ & & $\begin{array}{l}\text { Spaudinių } \\
\text { komplektavi- } \\
\text { mo skyrius }\end{array}$ & $\begin{array}{l}\text { Kiti iparei- } \\
\text { gojimai IAV } \\
\text { (informacinė } \\
\text { analitiné } \\
\text { veikla) }\end{array}$ & & & & B & $\begin{array}{l}\text { Filolo- } \\
\text { gija }\end{array}$ & & & & & & & \\
\hline
\end{tabular}

* Vykdo: funkcija registruojama tokiu atveju, kai pareigybei pavesta savarankiškai atlikti visus su tyrimu susijusius darbus, t. y. parengti konkretaus tyrimo programą, dokumentus, nustatyti imți, surinkti ir apibendrinti gautus duomenis, parengti tyrimo ataskaitą ataskaitą ir t. t.

** Dalyvauja: funkcija registruojama tokiu atveju, kai pareigybei pavedama atlikti dalị su bet kuriuo iš atliekamų tyrimų susijusių darbų, pavyzdžiui, parengti anketą, surinkti ir apibendrinti jos duomenis, arba parengti tą tyrimo dali, kuriai bus naudojami kiekybiniai tyrimo metodai, surinkti šiuos duomenis ir juos apibendrinti ir t. t., ir pan.

*** Skiria darbo laiko: siūlytina registruoti tik tuo atveju, jei veiklos srit̨i reglamentuojančiuose dokumentuose nurodyta, kiek darbo laiko skiria konkreti pareigybė moksliniam tiriamajam darbui. Ten, kur nenurodyta, rekomenduojama tiesiog pažymėti $\mathrm{N}$ raide (nežino, neteikiama).

**** Išsimokslinimo sritys nurodomos pagal ịrašus konkretaus asmens kvalifikacijos lygị patvirtinančiuose dokumentuose.

***** Išsimokslinimo ir kvalifikacinio lygmens registravimo kodai.

\begin{tabular}{|c|c|c|}
\hline 1. Specialusis išsimokslinimas & Kodas & Kvalifikacinis lygis \\
\hline 1.1. Aukštasis specialusis išsimokslinimas & & \\
\hline Aukštos kvalifikacijos bibliotekininko ir bibliografo studijų programa (iki 1995 metų, universitetinè, 5 metai) & M/-95 & \\
\hline $\begin{array}{l}\text { Bibliotekininkystès, informacijos (ar) komunikacijos krypties bakalauro studijų programa aukštojoje universitetinèje } \\
\text { mokykloje }\end{array}$ & B & Bakalauras \\
\hline
\end{tabular}




\begin{tabular}{|c|c|c|}
\hline $\begin{array}{l}\text { Bibliotekininkystès, informacijos (ar) komunikacijos krypties magistro studijų programa aukštojoje universitetinèje } \\
\text { mokykloje }\end{array}$ & M & Magistras \\
\hline \multicolumn{3}{|l|}{ 1.2. Aukštesnysis specialusis išsimokslinimas } \\
\hline $\begin{array}{l}\text { 1.2.1. Bibliotekininkystés, informacijos (ar) komunikacijos krypties studijų programa aukštojoje neuniversitetinèje } \\
\text { mokykloje }\end{array}$ & $\mathrm{PB}$ & Profesinis bakalauras \\
\hline 1.2.2. Specialioji (kultūros) mokykla, bibliotekininkystès ir bibliografijos specialybè (iki 1995 metu) & S & Specialistas \\
\hline \multicolumn{3}{|l|}{ 2. Kitos srities (ne bibliotekinis) išsimokslinimas } \\
\hline \multicolumn{3}{|l|}{ 2.1. Aukštasis išsimokslinimas } \\
\hline 2.1.1. Universitetinè ( 5 metu) bet kurios krypties trukmès studijų programa (iki 1995 metų) & $\mathrm{M} /-95$ & \\
\hline 2.1.2. Universitetinè bet kurios krypties studiju programa (po 1995 metu) & $\mathrm{B}$ & Bakalauras \\
\hline 2.1.3. Universitetinè bet kurios krypties studijų programa (po 1995 metu) & M & Magistras \\
\hline 2.1.4. Pastaba. Jei darbuotojas yra igijęs sociologijos bakalauro kvalifikacinį laipsnị & Bsoc & $\begin{array}{l}\text { Sociologijos baka- } \\
\text { lauras }\end{array}$ \\
\hline 2.1.5. Jei darbuotojas yra igijęs sociologijos magistro kvalifikacinị laipsnị & Msoc & $\begin{array}{l}\text { Sociologijos magis- } \\
\text { tras }\end{array}$ \\
\hline 2.1.6. Bet kurios krypties studijų programa neuniversitetinëje aukštojoje mokykloje (po 1995 metu) & $\mathrm{PB}$ & Profesinis bakalauras \\
\hline 2.1.7. Pastaba. Jei darbuotojas yra igijęs sociologijos profesinị bakalauro kvalifikacinị laipsnị & PBsoc & $\begin{array}{l}\text { Sociologijos profesi- } \\
\text { nis bakalauras }\end{array}$ \\
\hline \multicolumn{3}{|l|}{ 2.2. Aukštesnysis išsimokslinimas } \\
\hline $\begin{array}{l}\text { 2.2.1. Bet kurios krypties studijų programa technikume ar jam prilygintoje kitoje aukštesniojoje mokykloje (iki } 1995 \\
\text { metu) }\end{array}$ & $S$ & Specialistas \\
\hline \multicolumn{3}{|l|}{ 2.3. Kitas išsimokslinimas } \\
\hline 2.3.1. Žemesnio nei technikumo lygmens (iki 1995 metu) ir bendrojo lavinimo programa mokykloje & BV & Bendrasis vidurinis \\
\hline
\end{tabular}




\section{MOKSLO DARBŲ REGISTRAS N APSKRIČIŲ SAVIVALDYBIŲ VIEŠOSIOSE BIBLIOTEKOSE}

\begin{tabular}{|c|c|c|c|c|c|c|c|c|c|c|c|}
\hline \multirow[b]{3}{*}{$\begin{array}{l}\text { Eil. } \\
\text { Nr. }\end{array}$} & \multirow[b]{3}{*}{ Darbo rezultatas } & \multirow{3}{*}{$\begin{array}{c}\text { Savival- } \\
\text { dybès } \\
\text { viešoji } \\
\text { biblio- } \\
\text { teka } \\
\text { (siste- } \\
\text { ma) }\end{array}$} & \multirow[b]{3}{*}{$\begin{array}{l}\text { Darbui identifikuoti reikalingi duomenys } \\
\text { (bibliografinio aprašo forma): autorius, pava- } \\
\text { dinimas, išleidimo vieta, leidèjas, publikavimo } \\
\text { šaltinis, apimtis ir kt. duomenys }\end{array}$} & \multicolumn{8}{|c|}{ Darbo vertinimas balais (nuo 0 iki 5 pagal vertinimo kriterijus) } \\
\hline & & & & \multicolumn{4}{|c|}{$\begin{array}{l}\text { Darbo parengimas ir mokslinis } \\
\text { (dalykinis) išbaigtumas }\end{array}$} & \multicolumn{3}{|c|}{$\begin{array}{c}\text { Darbo ịforminimo } \\
\text { kokybe }\end{array}$} & \multirow[b]{2}{*}{$\begin{array}{l}\text { ben- } \\
\text { dras } \\
\text { verti- } \\
\text { nimas } \\
\text { (ba- } \\
\text { lais) }\end{array}$} \\
\hline & & & & \begin{tabular}{|c|} 
temos \\
parinki- \\
mas ir \\
problemos \\
pagrindi- \\
mas
\end{tabular} & $\begin{array}{c}\text { me- } \\
\text { todi- } \\
\text { ka }\end{array}$ & $\begin{array}{c}\text { problemos } \\
\text { analizés koky- } \\
\text { bė, mokslinis } \\
\text { (dalykinis) } \\
\text { pagrindimas }\end{array}$ & \begin{tabular}{|c|} 
išva- \\
dos ir \\
reko- \\
men- \\
daci- \\
jos \\
\end{tabular} & \begin{tabular}{|c|} 
darbo \\
struk- \\
tūra ir \\
pagrin- \\
dinès \\
jos dalys \\
\end{tabular} & \begin{tabular}{|c|} 
citavimo \\
sistema \\
ir biblio- \\
grafinių \\
šaltiniu \\
sąrašas \\
\end{tabular} & $\begin{array}{c}\text { teksto } \\
\text { ilius- } \\
\text { travi- } \\
\text { mas }\end{array}$ & \\
\hline 1. & $\begin{array}{l}\text { Moksliniai tyri- } \\
\text { mai. Ataskaita }\end{array}$ & & $\begin{array}{l}\text { Tyrimo ataskaitos aprašo šablonas; jei elek- } \\
\text { troninis išteklius, aprašoma pagal e. išteklių } \\
\text { aprašui taikomus reikalavimus: } \\
\text { AUTORIAUS PAVARDĖ, Vardas. Antraštè. } \\
\text { Išleidimo vieta: leidëjas, data. Ataskaitos nume- } \\
\text { ris (jeigu yra). Apimtis (jeigu galima nustatyti). }\end{array}$ & & & & & & & & \\
\hline & & & $\begin{array}{l}\text { Pavyzdys } \\
\text { Bibliotekos pažangai: pokyčiai bibliotekose ir vi- } \\
\text { suomenejje: poveikio vertinimo tyrimu } 2010 \mathrm{~m} \text {. } \\
\text { ataskaita. Vilnius: Lietuvos nac. M. Mažvydo } \\
\text { b-ka, [2011]. [125 p]. }\end{array}$ & & & & & & & & \\
\hline 2. & $\begin{array}{l}\text { Rinkos tyri- } \\
\text { mams priskiria- } \\
\text { mi darbai }\end{array}$ & & $\begin{array}{l}\text { AUTORIAUS PAVARDĖ, Vardas. Antrašté. Iš- } \\
\text { leidimo vieta: leidejas, data. Ataskaitos numeris } \\
\text { (jeigu yra). Apimtis (jeigu galima nustatyti). }\end{array}$ & & & & & & & & \\
\hline & & & $\begin{array}{l}\text { Pvz., aprašomas tyrimas, pristatytas b-kos } \\
\text { metų veiklos ataskaitoje. }\end{array}$ & & & & & & & & \\
\hline
\end{tabular}




\begin{tabular}{|c|c|c|c|c|c|c|c|c|c|c|c|}
\hline \multirow[b]{3}{*}{$\begin{array}{l}\text { Eil. } \\
\text { Nr. }\end{array}$} & \multirow[b]{3}{*}{ Darbo rezultatas } & \multirow{3}{*}{$\begin{array}{l}\text { Savival- } \\
\text { dybès } \\
\text { viešoji } \\
\text { biblio- } \\
\text { teka } \\
\text { (siste- } \\
\text { ma) }\end{array}$} & \multirow[b]{3}{*}{$\begin{array}{l}\text { Darbui identifikuoti reikalingi duomenys } \\
\text { (bibliografinio aprašo forma): autorius, pava- } \\
\text { dinimas, išleidimo vieta, leidèjas, publikavimo } \\
\text { šaltinis, apimtis ir kt. duomenys }\end{array}$} & \multicolumn{8}{|c|}{ Darbo vertinimas balais (nuo 0 iki 5 pagal vertinimo kriterijus) } \\
\hline & & & & \multicolumn{4}{|c|}{$\begin{array}{c}\begin{array}{c}\text { Darbo parengimas ir mokslinis } \\
\text { (dalykinis) išbaigtumas }\end{array} \\
\end{array}$} & \multicolumn{3}{|c|}{$\begin{array}{c}\text { Darbo ifforminimo } \\
\text { kokybe }\end{array}$} & \multirow[b]{2}{*}{$\begin{array}{l}\text { ben- } \\
\text { dras } \\
\text { verti- } \\
\text { nimas } \\
\text { (ba- } \\
\text { lais) }\end{array}$} \\
\hline & & & & \begin{tabular}{|} 
temos \\
parinki- \\
mas ir \\
problemos \\
pagrindi- \\
mas
\end{tabular} & $\begin{array}{l}\text { me- } \\
\text { todi- } \\
\text { ka }\end{array}$ & \begin{tabular}{|c|} 
problemos \\
analizès koky- \\
bé, mokslinis \\
(dalykinis) \\
pagrindimas
\end{tabular} & $\begin{array}{l}\text { išva- } \\
\text { dos ir } \\
\text { reko- } \\
\text { men- } \\
\text { daci- } \\
\text { jos }\end{array}$ & $\begin{array}{l}\text { darbo } \\
\text { struk- } \\
\text { tūra ir } \\
\text { pagrin- } \\
\text { dinès } \\
\text { jos dalys }\end{array}$ & \begin{tabular}{|l} 
citavimo \\
sistema \\
ir biblio- \\
grafinių \\
šaltinių \\
sąrašas
\end{tabular} & $\begin{array}{c}\text { teksto } \\
\text { ilius- } \\
\text { travi- } \\
\text { mas }\end{array}$ & \\
\hline & & $\begin{array}{l}\text { Alytaus } \\
\text { r. SVB }\end{array}$ & $\begin{array}{l}\text { [Alytaus rajono SVB suaugusiuju skaitytoju } \\
\text { skaitymo analize. Alytus, Alytaus rajono savi- } \\
\text { valdybes viešoji b-ka, 2010]. [Nepublikuota, } \\
\text { šaltinis: Alytaus r. SVB veiklos ataskaita, 2011, } \\
\text { p. 25]. }\end{array}$ & & & & & & & & \\
\hline & & $\begin{array}{l}\text { Elek- } \\
\text { trénu } \\
\text { SVB }\end{array}$ & $\begin{array}{l}\text { Mums svarbi Jüsu nuomonè [vartotojų pasi- } \\
\text { tenkinimo teikiamomis paslaugomis b-koje } \\
\text { vertinimas. Elektrennai: Elektrènų savivaldybès } \\
\text { viešoji b-ka, 2010]. [Nepublikuota, šaltinis: } \\
\text { Elektrènų SVB veiklos ataskaita, 2011, p. 74]. }\end{array}$ & & & & & & & & \\
\hline & & $\begin{array}{l}\text { Kèdai- } \\
\text { nių r. } \\
\text { SVB }\end{array}$ & $\begin{array}{l}\text { Reklama ir jos poveikis vartotoju elgsenai Ké- } \\
\text { dainiu rajono savivaldybes Mikalojaus Daukšos } \\
\text { viešojoje bibliotekoje: [tyrimo ataskaita?] Kè- } \\
\text { dainiai: Kèdainių rajono savivaldybès Mikalo- } \\
\text { jaus Daukšos viešoji biblioteka, 2013. P. ... . } \\
\text { [Nepublikuota, šaltinis: Kèdainių r. SVB } 2013 \\
\text { metų veiklos ataskaita, 2014, p. 27]. }\end{array}$ & & & & & & & & \\
\hline
\end{tabular}




\begin{tabular}{|c|c|c|c|c|c|c|c|c|c|c|c|}
\hline \multirow[b]{3}{*}{$\begin{array}{l}\text { Eil. } \\
\text { Nr. }\end{array}$} & \multirow[b]{3}{*}{ Darbo rezultatas } & \multirow{3}{*}{$\begin{array}{l}\text { Savival- } \\
\text { dybès } \\
\text { viešoji } \\
\text { biblio- } \\
\text { teka } \\
\text { (siste- } \\
\text { ma) }\end{array}$} & \multirow[b]{3}{*}{$\begin{array}{l}\text { Darbui identifikuoti reikalingi duomenys } \\
\text { (bibliografinio aprašo forma): autorius, pava- } \\
\text { dinimas, išleidimo vieta, leidejjas, publikavimo } \\
\text { šaltinis, apimtis ir kt. duomenys }\end{array}$} & \multicolumn{8}{|c|}{ Darbo vertinimas balais (nuo 0 iki 5 pagal vertinimo kriterijus) } \\
\hline & & & & \multicolumn{4}{|c|}{$\begin{array}{l}\text { Darbo parengimas ir mokslinis } \\
\text { (dalykinis) išbaigtumas }\end{array}$} & \multicolumn{3}{|c|}{$\begin{array}{c}\text { Darbo ịforminimo } \\
\text { kokybè }\end{array}$} & \multirow[b]{2}{*}{$\begin{array}{l}\text { ben- } \\
\text { dras } \\
\text { verti- } \\
\text { nimas } \\
\text { (ba- } \\
\text { lais) }\end{array}$} \\
\hline & & & & \begin{tabular}{|c|} 
temos \\
parinki- \\
mas ir \\
problemos \\
pagrindi- \\
mas \\
\end{tabular} & $\begin{array}{c}\text { me- } \\
\text { todi- } \\
\text { ka }\end{array}$ & $\begin{array}{c}\text { problemos } \\
\text { analizés koky- } \\
\text { bé, mokslinis } \\
\text { (dalykinis) } \\
\text { pagrindimas }\end{array}$ & $\begin{array}{l}\text { išva- } \\
\text { dos ir } \\
\text { reko- } \\
\text { men- } \\
\text { daci- } \\
\text { jos }\end{array}$ & $\begin{array}{l}\text { darbo } \\
\text { struk- } \\
\text { tūra ir } \\
\text { pagrin- } \\
\text { dinès } \\
\text { jos dalys }\end{array}$ & $\begin{array}{l}\text { citavimo } \\
\text { sistema } \\
\text { ir biblio- } \\
\text { grafinių } \\
\text { šaltinių } \\
\text { sąrašas } \\
\end{array}$ & $\begin{array}{c}\text { teksto } \\
\text { ilius- } \\
\text { travi- } \\
\text { mas }\end{array}$ & \\
\hline & & $\begin{array}{l}\text { Kèdai- } \\
\text { nių r. } \\
\text { SVB }\end{array}$ & $\begin{array}{l}\text { Kédainiu rajono savivaldybès Mikalojaus } \\
\text { Daukšos viěsosios bibliotekos ìvaizdis vartotojo } \\
\text { ir darbuotojo požiūriu: tyrimo ataskaita? Kèdai- } \\
\text { niai: Kèdainių rajono savivaldybės Mikalojaus } \\
\text { Daukšos viešoji b-ka, 2013. P. [Nepublikuo- } \\
\text { ta?, šaltinis: Kèdainių r. SVB veiklos ataskaita, } \\
\text { 2014, p. 27]. }\end{array}$ & & & & & & & & \\
\hline & & $\begin{array}{l}\text { Kèdai- } \\
\text { nių r. } \\
\text { SVB }\end{array}$ & $\begin{array}{l}\text { „Nuo } 2002 \text { metų renkami ir analizuojami } \\
\text { duomenys apie VB padalinių vartotoju kon- } \\
\text { tingentą jo pokyčius, paslaugų ir dokumentų } \\
\text { naudojimą" [Šaltinis: Kedainių r. SVB veiklos } \\
\text { ataskaita, 2015, p. 28]. }\end{array}$ & & & & & & & & \\
\hline 3. & $\begin{array}{l}\text { Tyrimai, skirti } \\
\text { vadybiniams } \\
\text { sprendimams } \\
\text { pagrįsti }\end{array}$ & & & & & & & & & & \\
\hline & & $\begin{array}{l}\text { Alytaus } \\
\text { r. SVB }\end{array}$ & $\begin{array}{l}\text { Periodiniu leidiniu skaitymas Alytaus rajono } \\
\text { savivaldybes viěsojoje bibliotekoje: vartotoju } \\
\text { apklausa, ataskaita. Alytus: Alytaus rajono } \\
\text { savivaldybès viešoji b-ka, [2011] [nepublikuo- } \\
\text { ta, šaltinis: Alytaus r. SVB veiklos ataskaita, } \\
\text { 2012, p. 24]. }\end{array}$ & & & & & & & & \\
\hline
\end{tabular}




\begin{tabular}{|c|c|c|c|c|c|c|c|c|c|c|c|}
\hline \multirow[b]{3}{*}{$\begin{array}{l}\text { Eil. } \\
\text { Nr. }\end{array}$} & \multirow[b]{3}{*}{ Darbo rezultatas } & \multirow{3}{*}{$\begin{array}{l}\text { Savival- } \\
\text { dybés } \\
\text { viešoji } \\
\text { biblio- } \\
\text { teka } \\
\text { (siste- } \\
\text { ma) }\end{array}$} & \multirow[b]{3}{*}{$\begin{array}{l}\text { Darbui identifikuoti reikalingi duomenys } \\
\text { (bibliografinio aprašo forma): autorius, pava- } \\
\text { dinimas, išleidimo vieta, leidejjas, publikavimo } \\
\text { šaltinis, apimtis ir kt. duomenys }\end{array}$} & \multicolumn{8}{|c|}{ Darbo vertinimas balais (nuo 0 iki 5 pagal vertinimo kriterijus) } \\
\hline & & & & \multicolumn{4}{|c|}{\begin{tabular}{|c|} 
Darbo parengimas ir mokslinis \\
(dalykinis) išbaigtumas
\end{tabular}} & \multicolumn{3}{|c|}{$\begin{array}{c}\text { Darbo îforminimo } \\
\text { kokybe }\end{array}$} & \multirow[b]{2}{*}{$\begin{array}{l}\text { ben- } \\
\text { dras } \\
\text { verti- } \\
\text { nimas } \\
\text { (ba- } \\
\text { lais) }\end{array}$} \\
\hline & & & & \begin{tabular}{|c|} 
temos \\
parinki- \\
mas ir \\
problemos \\
pagrindi- \\
mas
\end{tabular} & $\begin{array}{c}\text { me- } \\
\text { todi- } \\
\text { ka }\end{array}$ & \begin{tabular}{|c|} 
problemos \\
analizés koky- \\
bé, mokslinis \\
(dalykinis) \\
pagrindimas
\end{tabular} & $\begin{array}{l}\text { išva- } \\
\text { dos ir } \\
\text { reko- } \\
\text { men- } \\
\text { daci- } \\
\text { jos }\end{array}$ & $\begin{array}{l}\text { darbo } \\
\text { struk- } \\
\text { tūra ir } \\
\text { pagrin- } \\
\text { dines } \\
\text { jos dalys }\end{array}$ & \begin{tabular}{|c|} 
citavimo \\
sistema \\
ir biblio- \\
grafinių \\
šaltiniu \\
sąrašas
\end{tabular} & $\begin{array}{c}\text { teksto } \\
\text { ilius- } \\
\text { travi- } \\
\text { mas }\end{array}$ & \\
\hline & & $\begin{array}{l}\text { Alytaus } \\
\text { r. SVB }\end{array}$ & $\begin{array}{l}\text { [Periodiniu leidiniu skaitymas Alytaus rajono } \\
\text { savivaldybès viešojoje bibliotekoje: vartotojų } \\
\text { apklausa, ataskaita. Alytus: Alytaus rajono } \\
\text { savivaldybès viešoji b-ka, 2012] [nepublikuota, } \\
\text { šaltinis: Alytaus r. SVB veiklos ataskaita, 2013, } \\
\text { p. 25]. }\end{array}$ & & & & & & & & \\
\hline & & $\begin{array}{l}\text { Elek- } \\
\text { trénu } \\
\text { SVB }\end{array}$ & $\begin{array}{l}\text { Kaq skaitote?: [VB suaugusiujų vartotojų ap- } \\
\text { klausa, siekiant išsiaiškinti labiausiai skaitomus } \\
\text { leidinius ir kokių leidinių labiausiai trūksta } \\
\text { bibliotekos fonde]. Elektrenai: Elektrènų savi- } \\
\text { valdybès viešoji b-ka, 2011]. [Nepublikuota, } \\
\text { šaltinis: Elektrènų SVB veiklos ataskaita, 2012, } \\
\text { p. 67]. }\end{array}$ & & & & & & & & \\
\hline & & $\begin{array}{l}\text { Elek- } \\
\text { trénų } \\
\text { SVB }\end{array}$ & $\begin{array}{l}\text { Paaugliu ir jaunimo poreikių Elektrènu savi- } \\
\text { valdybes viešojoje bibliotekoje tyrimas: tyrimo } \\
\text { ataskaita. Elektrenai: Elektrènų savivaldybès } \\
\text { viešoji b-ka, 2015]. [Nepublikuota?, šaltinis: } \\
\text { Elektrènų SVB veiklos ataskaita, 2011, } \\
\text { p. 74]. }\end{array}$ & & & & & & & & \\
\hline
\end{tabular}




\begin{tabular}{|c|c|c|c|c|c|c|c|c|c|c|c|}
\hline \multirow[b]{3}{*}{$\begin{array}{l}\text { Eil. } \\
\text { Nr. }\end{array}$} & \multirow[b]{3}{*}{ Darbo rezultatas } & \multirow{3}{*}{$\begin{array}{l}\text { Savival- } \\
\text { dybès } \\
\text { viešoji } \\
\text { biblio- } \\
\text { teka } \\
\text { (siste- } \\
\text { ma) }\end{array}$} & \multirow{3}{*}{$\begin{array}{l}\text { Darbui identifikuoti reikalingi duomenys } \\
\text { (bibliografinio aprašo forma): autorius, pava- } \\
\text { dinimas, išleidimo vieta, leidejjas, publikavimo } \\
\text { šaltinis, apimtis ir kt. duomenys }\end{array}$} & \multicolumn{8}{|c|}{ Darbo vertinimas balais (nuo 0 iki 5 pagal vertinimo kriterijus) } \\
\hline & & & & \multicolumn{4}{|c|}{$\begin{array}{l}\text { Darbo parengimas ir mokslinis } \\
\text { (dalykinis) išbaigtumas }\end{array}$} & \multicolumn{3}{|c|}{\begin{tabular}{|c|}
$\begin{array}{c}\text { Darbo ịforminimo } \\
\text { kokybė }\end{array}$ \\
\end{tabular}} & \multirow[b]{2}{*}{$\begin{array}{l}\text { ben- } \\
\text { dras } \\
\text { verti- } \\
\text { nimas } \\
\text { (ba- } \\
\text { lais) }\end{array}$} \\
\hline & & & & \begin{tabular}{|} 
temos \\
parinki- \\
mas ir \\
problemos \\
pagrindi- \\
mas
\end{tabular} & $\begin{array}{c}\text { me- } \\
\text { todi- } \\
\text { ka }\end{array}$ & $\begin{array}{c}\text { problemos } \\
\text { analizés koky- } \\
\text { bè, mokslinis } \\
\text { (dalykinis) } \\
\text { pagrindimas }\end{array}$ & $\begin{array}{l}\text { išva- } \\
\text { dos ir } \\
\text { reko- } \\
\text { men- } \\
\text { daci- } \\
\text { jos }\end{array}$ & \begin{tabular}{|c|} 
darbo \\
struk- \\
tūra ir \\
pagrin- \\
dinès \\
jos dalys \\
\end{tabular} & $\begin{array}{l}\text { citavimo } \\
\text { sistema } \\
\text { ir biblio- } \\
\text { grafinių } \\
\text { šaltinių } \\
\text { sąrašas } \\
\end{array}$ & $\begin{array}{c}\text { teksto } \\
\text { ilius- } \\
\text { travi- } \\
\text { mas }\end{array}$ & \\
\hline 4. & Kiti tyrimai & & & & & & & & & & \\
\hline \multirow[t]{2}{*}{5.} & Straipsniai** & & & & & & & & & & \\
\hline & & & $\begin{array}{l}\text { Straipsnio aprašo šablonas (periodiniame } \\
\text { leidinyje): AUTORIAUS PAVARDE, Vardas. } \\
\text { Straipsnio antraštė. Periodinio leidinio an- } \\
\text { traštè, metai, numeracija, puslapiai. e. prieiga } \\
\text { AUTORIAUS PAVARDË, Vardas. Straipsnio } \\
\text { antrašte. El. periodinio leidinio antrašte [lai- } \\
\text { kmenos žyma]. Metai, numeracija, puslapiai } \\
\text { [žiūrèta...]. Prieiga per internetą: URL adresas. }\end{array}$ & & & & & & & & \\
\hline 5.1. & $\begin{array}{l}\text { Straipsniai, } \\
\text { publikuoti ats- } \\
\text { kiruose mokslo } \\
\text { (recenzuotuose) } \\
\text { leidiniuose (kny- } \\
\text { goje, straipsnių } \\
\text { rinkinyje) }\end{array}$ & & $\begin{array}{l}\text { Straipsnio aprašo šablonas (knygoje ar kitas } \\
\text { monografiniame leidinyje): STRAIPSNIO } \\
\text { AUTORIAUS PAVARDË, Vardas. Straipsnio } \\
\text { pavadinimas. Ǐs: Leidinio AUTORIUS arba } \\
\text { REDAKTORIUS. Antraštė. Išleidimo vieta: } \\
\text { leidèjas, data, puslapiai. }\end{array}$ & & & & & & & & \\
\hline
\end{tabular}




\begin{tabular}{|c|c|c|c|c|c|c|c|c|c|c|c|}
\hline \multirow[b]{3}{*}{$\begin{array}{l}\text { Eil. } \\
\text { Nr. }\end{array}$} & \multirow[b]{3}{*}{ Darbo rezultatas } & \multirow{3}{*}{$\begin{array}{l}\text { Savival- } \\
\text { dybès } \\
\text { viešoji } \\
\text { biblio- } \\
\text { teka } \\
\text { (siste- } \\
\text { ma) }\end{array}$} & \multirow[b]{3}{*}{$\begin{array}{l}\text { Darbui identifikuoti reikalingi duomenys } \\
\text { (bibliografinio aprašo forma): autorius, pava- } \\
\text { dinimas, išleidimo vieta, leidejjas, publikavimo } \\
\text { šaltinis, apimtis ir kt. duomenys }\end{array}$} & \multicolumn{8}{|c|}{ Darbo vertinimas balais (nuo 0 iki 5 pagal vertinimo kriterijus) } \\
\hline & & & & \multicolumn{4}{|c|}{\begin{tabular}{|c|}
$\begin{array}{c}\text { Darbo parengimas ir mokslinis } \\
\text { (dalykinis) išbaigtumas }\end{array}$ \\
\end{tabular}} & \multicolumn{3}{|c|}{$\begin{array}{c}\text { Darbo ifforminimo } \\
\text { kokybe }\end{array}$} & \multirow[b]{2}{*}{$\begin{array}{l}\text { ben- } \\
\text { dras } \\
\text { verti- } \\
\text { nimas } \\
\text { (ba- } \\
\text { lais) }\end{array}$} \\
\hline & & & & \begin{tabular}{|c|} 
temos \\
parinki- \\
mas ir \\
problemos \\
pagrindi- \\
mas
\end{tabular} & $\begin{array}{c}\text { me- } \\
\text { todi- } \\
\text { ka }\end{array}$ & \begin{tabular}{|c|} 
\\
problemos \\
analizès koky- \\
bé, mokslinis \\
(dalykinis) \\
pagrindimas
\end{tabular} & $\begin{array}{l}\text { išva- } \\
\text { dos ir } \\
\text { reko- } \\
\text { men- } \\
\text { daci- } \\
\text { jos }\end{array}$ & $\begin{array}{l}\text { darbo } \\
\text { struk- } \\
\text { tūra ir } \\
\text { pagrin- } \\
\text { dinès } \\
\text { jos dalys }\end{array}$ & \begin{tabular}{|c|} 
citavimo \\
sistema \\
ir biblio- \\
grafinių \\
šaltinių \\
sąrašas \\
\end{tabular} & $\begin{array}{c}\text { teksto } \\
\text { ilius- } \\
\text { travi- } \\
\text { mas }\end{array}$ & \\
\hline 5.2 . & $\begin{array}{l}\text { Straipsniai, pu- } \\
\text { blikuoti recen- } \\
\text { zuojamuose*** } \\
\text { periodiniuose } \\
\text { leidiniuose }\end{array}$ & & $\begin{array}{l}\text { *** Recenzuojamujų mokslo žurnalų sąraša galite } \\
\text { rasti adresu: } \\
\text { http://www.mab.lt/lt/istekliai-internete/moks- } \\
\text { lo-zurnalai } \\
\text { Mokslo straipsniai. Tai straipsnis, paskelbtas } \\
\text { mokslinėje spaudoje. Nors visuomeninių } \\
\text { mokslų straipsnių struktūros nėra griežtai nu- } \\
\text { statytos, paprastai mokslinių periodinių lei- } \\
\text { dinių redakcinès kolegijos pateikia mokslinių } \\
\text { straipsnių struktūros reikalavimus: privalomi } \\
\text { mokslinio straipsnio struktūros elementai yra } \\
\text { antraštė, anotacija, įvadas, rezultatai, išvados ir } \\
\text { literatūros sąrašas. }\end{array}$ & & & & & & & & \\
\hline 5.3 . & $\begin{array}{l}\text { Straipsniai, } \\
\text { publikuoti na- } \\
\text { cionaliniuose } \\
\text { (centriniuose) } \\
\text { kultūros ir } \\
\text { meno leidi- } \\
\text { niuose }\end{array}$ & & $\begin{array}{l}\text { Registruojami, jei atitinka moksliniam straips- } \\
\text { niui keliamus (taip pat ir struktūros) reikalavi- } \\
\text { mus. Tyrimo tikslams registruojami ir moks- } \\
\text { linio tyrimo pagrindu parengti publicistiniai } \\
\text { straipsniai, jei juose pateikiami pagrindiniai } \\
\text { moksliniam straipsniui priskiriami elementai: } \\
\text { įvadas, rezultatai, išvados ir literatūros sąrašas. }\end{array}$ & & & & & & & & \\
\hline
\end{tabular}




\begin{tabular}{|c|c|c|c|c|c|c|c|c|c|c|c|}
\hline \multirow[b]{3}{*}{$\begin{array}{l}\text { Eil. } \\
\text { Nr. }\end{array}$} & \multirow[b]{3}{*}{ Darbo rezultatas } & \multirow{3}{*}{$\begin{array}{l}\text { Savival- } \\
\text { dybès } \\
\text { viešoji } \\
\text { biblio- } \\
\text { teka } \\
\text { (siste- } \\
\text { ma) }\end{array}$} & \multirow{3}{*}{$\begin{array}{l}\text { Darbui identifikuoti reikalingi duomenys } \\
\text { (bibliografinio aprašo forma): autorius, pava- } \\
\text { dinimas, išleidimo vieta, leidèjas, publikavimo } \\
\text { šaltinis, apimtis ir kt. duomenys }\end{array}$} & \multicolumn{8}{|c|}{ Darbo vertinimas balais (nuo 0 iki 5 pagal vertinimo kriterijus) } \\
\hline & & & & \multicolumn{4}{|c|}{$\begin{array}{l}\text { Darbo parengimas ir mokslinis } \\
\text { (dalykinis) išbaigtumas }\end{array}$} & \multicolumn{3}{|c|}{$\begin{array}{c}\begin{array}{c}\text { Darbo įforminimo } \\
\text { kokybe }\end{array} \\
\end{array}$} & \multirow{2}{*}{$\begin{array}{l}\text { ben- } \\
\text { dras } \\
\text { verti- } \\
\text { nimas } \\
\text { (ba- } \\
\text { lais) }\end{array}$} \\
\hline & & & & \begin{tabular}{|c|} 
temos \\
parinki- \\
mas ir \\
problemos \\
pagrindi- \\
mas
\end{tabular} & $\begin{array}{c}\text { me- } \\
\text { todi- } \\
\text { ka }\end{array}$ & $\begin{array}{c}\text { problemos } \\
\text { analizés koky- } \\
\text { bè, mokslinis } \\
\text { (dalykinis) } \\
\text { pagrindimas }\end{array}$ & $\begin{array}{l}\text { išva- } \\
\text { dos ir } \\
\text { reko- } \\
\text { men- } \\
\text { daci- } \\
\text { jos }\end{array}$ & \begin{tabular}{|c|} 
darbo \\
struk- \\
tūra ir \\
pagrin- \\
dinès \\
jos dalys \\
\end{tabular} & $\begin{array}{c}\text { citavimo } \\
\text { sistema } \\
\text { ir biblio- } \\
\text { grafinių } \\
\text { šaltinių } \\
\text { sąrašas } \\
\end{array}$ & $\begin{array}{c}\text { teksto } \\
\text { ilius- } \\
\text { travi- } \\
\text { mas }\end{array}$ & \\
\hline 5.4 & $\begin{array}{l}\text { Straipsniai, } \\
\text { publikuoti } \\
\text { profesiniuose } \\
\text { periodiniuose } \\
\text { leidiniuose }\end{array}$ & & $\begin{array}{l}\text { Registruojami, jei atitinka moksliniam straips- } \\
\text { niui keliamus (taip pat ir struktūros) reikalavi- } \\
\text { mus. Tyrimo tikslams registruojami ir moks- } \\
\text { linio tyrimo pagrindu parengti publicistiniai } \\
\text { straipsniai, jei juose pateikiami pagrindiniai } \\
\text { moksliniam straipsniui priskiriami elementai: } \\
\text { ivvadas, rezultatai, išvados ir literatūros sąrašas. }\end{array}$ & & & & & & & & \\
\hline 5.5 . & \begin{tabular}{|l|} 
Straipsniai, pu- \\
blikuoti regio- \\
niniuose, vietos \\
leidiniuose; \\
mokslo populia- \\
rinimo ar kitos \\
paskirties leidi- \\
niuose \\
\end{tabular} & & $\begin{array}{l}\text { Registruojami darbai, kurie atitinka moksli- } \\
\text { niam straipsniui keliamus (taip pat ir struktū- } \\
\text { ros) reikalavimus. Tyrimo tikslams registruo- } \\
\text { jami ir mokslinio tyrimo pagrindu parengti } \\
\text { mokslui populiarinti skirti straipsniai, jei juose } \\
\text { pateikiami pagrindiniai moksliniam straipsniui } \\
\text { priskiriami elementai: ǐvadas, rezultatai, išva- } \\
\text { dos ir literatūros sąrašas. }\end{array}$ & & & & & & & & \\
\hline 5.6. & \begin{tabular}{|l|} 
Specialiai tyrimo \\
tikslams: straips- \\
niai, kuriuose \\
pristatomi ar \\
apžvelgiami ak- \\
tualūs bibliotekai \\
moksliniai tyri- \\
mai jų rezultatu \\
panaudojimo ar \\
specialiai sklaidos \\
tikslams
\end{tabular} & & & & & & & & & & \\
\hline
\end{tabular}




\begin{tabular}{|c|c|c|c|c|c|c|c|c|c|c|c|}
\hline \multirow[b]{3}{*}{$\begin{array}{l}\text { Eil. } \\
\text { Nr. }\end{array}$} & \multirow[b]{3}{*}{ Darbo rezultatas } & \multirow{3}{*}{$\begin{array}{c}\text { Savival- } \\
\text { dybès } \\
\text { viešoji } \\
\text { biblio- } \\
\text { teka } \\
\text { (siste- } \\
\text { ma) }\end{array}$} & \multirow{3}{*}{$\begin{array}{l}\text { Darbui identifikuoti reikalingi duomenys } \\
\text { (bibliografinio aprašo forma): autorius, pava- } \\
\text { dinimas, išleidimo vieta, leidejjas, publikavimo } \\
\text { šaltinis, apimtis ir kt. duomenys }\end{array}$} & \multicolumn{8}{|c|}{ Darbo vertinimas balais (nuo 0 iki 5 pagal vertinimo kriterijus) } \\
\hline & & & & \multicolumn{4}{|c|}{$\begin{array}{l}\text { Darbo parengimas ir mokslinis } \\
\text { (dalykinis) išbaigtumas }\end{array}$} & \multicolumn{3}{|c|}{$\begin{array}{c}\text { Darbo ifforminimo } \\
\text { kokybe }\end{array}$} & \multirow[b]{2}{*}{$\begin{array}{l}\text { ben- } \\
\text { dras } \\
\text { verti- } \\
\text { nimas } \\
\text { (ba- } \\
\text { lais) }\end{array}$} \\
\hline & & & & \begin{tabular}{|c|} 
temos \\
parinki- \\
mas ir \\
problemos \\
pagrindi- \\
mas
\end{tabular} & $\begin{array}{c}\text { me- } \\
\text { todi- } \\
\text { ka }\end{array}$ & \begin{tabular}{|} 
problemos \\
analizės koky- \\
bè, mokslinis \\
(dalykinis) \\
pagrindimas
\end{tabular} & $\begin{array}{l}\text { išva- } \\
\text { dos ir } \\
\text { reko- } \\
\text { men- } \\
\text { daci- } \\
\text { jos }\end{array}$ & \begin{tabular}{|c|} 
darbo \\
struk- \\
tūra ir \\
pagrin- \\
dinès \\
jos dalys \\
\end{tabular} & $\begin{array}{c}\text { citavimo } \\
\text { sistema } \\
\text { ir biblio- } \\
\text { grafinių } \\
\text { šaltinių } \\
\text { sąrašas }\end{array}$ & $\begin{array}{c}\text { teksto } \\
\text { ilius- } \\
\text { travi- } \\
\text { mas }\end{array}$ & \\
\hline 6. & $\begin{array}{l}\text { Sudaryti mokslo } \\
\text { darbai }\end{array}$ & & $\begin{array}{l}\text { Registruojami tie darbai, kurių sudarytojai yra } \\
\text { konkrečios viešosios bibliotekos darbuotojai, } \\
\text { o rinkinyje publikuoti darbai yra recenzuoti. } \\
\text { Tyrimo tikslams registruojami ir tie publicisti- } \\
\text { niai ar mokslui populiarinti skirti darbai, kuriu } \\
\text { sudarytojai yra konkrečios bibliotekos darbuo- } \\
\text { tojai ir kuriuose remiamasi toje konkrečioje } \\
\text { bibliotekoje atliktais tyrimais (moksliniais, rin- } \\
\text { kodaros ar vadybiniams sprendimams priimti) } \\
\text { arba sudarytieji rinkiniai skirti bibliotekinin- } \\
\text { kystès, bibliografijos ar informacijos mokslo ar } \\
\text { šios srities moksliniams darbams populiarinti. }\end{array}$ & & & & & & & & \\
\hline & $\begin{array}{l}\text { Pranešimai } \\
\text { moksliniam } \\
\text { (moksliniam- } \\
\text { praktiniam) } \\
\text { renginiui }\end{array}$ & & $\begin{array}{l}\text { Registruojami pranešimai, kurie parengti atliktų } \\
\text { tyrimu pagrindu ir (arba) pristatyti mokslinia- } \\
\text { me, moksliniame-praktiniame seminare, moks- } \\
\text { linëje konferencijoje, simpoziume ar kitame } \\
\text { tokio statuso renginyje. Jei pranešimas parengtas } \\
\text { moksliniu tyrimų pagrindu, būtina nurodyti } \\
\text { tuos tyrimus. } \\
\text { Pranešimo aprašymo šablonas: AUTO- } \\
\text { RIAUS PAVARDĖ, Vardas. Pranešimo pava- } \\
\text { dinimas (tema). Pranešimas parengtas tyrimo } \\
\text { [nurodomas tyrimo pavadinimas] pagrindu. } \\
\text { Renginio, kuriame skaitytas pranešimas, rūšis, }\end{array}$ & & & & & & & & \\
\hline
\end{tabular}




\begin{tabular}{|c|c|c|c|c|c|c|c|c|c|c|c|}
\hline \multirow[b]{3}{*}{$\begin{array}{l}\text { Eil. } \\
\text { Nr. }\end{array}$} & \multirow[b]{3}{*}{ Darbo rezultatas } & \multirow{3}{*}{$\begin{array}{l}\text { Savival- } \\
\text { dybès } \\
\text { viešoji } \\
\text { biblio- } \\
\text { teka } \\
\text { (siste- } \\
\text { ma) }\end{array}$} & \multirow[b]{3}{*}{$\begin{array}{l}\text { Darbui identifikuoti reikalingi duomenys } \\
\text { (bibliografinio aprašo forma): autorius, pava- } \\
\text { dinimas, išleidimo vieta, leidèjas, publikavimo } \\
\text { šaltinis, apimtis ir kt. duomenys }\end{array}$} & \multicolumn{8}{|c|}{ Darbo vertinimas balais (nuo 0 iki 5 pagal vertinimo kriterijus) } \\
\hline & & & & \multicolumn{4}{|c|}{$\begin{array}{l}\text { Darbo parengimas ir mokslinis } \\
\text { (dalykinis) išbaigtumas }\end{array}$} & \multicolumn{3}{|c|}{$\begin{array}{c}\text { Darbo ifforminimo } \\
\text { kokybe }\end{array}$} & \multirow[b]{2}{*}{$\begin{array}{c}\text { ben- } \\
\text { dras } \\
\text { verti- } \\
\text { nimas } \\
\text { (ba- } \\
\text { lais) }\end{array}$} \\
\hline & & & & \begin{tabular}{|c|} 
temos \\
parinki- \\
mas ir \\
problemos \\
pagrindi- \\
mas \\
\end{tabular} & $\begin{array}{c}\text { me- } \\
\text { todi- } \\
\text { ka }\end{array}$ & $\begin{array}{c}\text { problemos } \\
\text { analizés koky- } \\
\text { bé, mokslinis } \\
\text { (dalykinis) } \\
\text { pagrindimas }\end{array}$ & $\begin{array}{l}\text { išva- } \\
\text { dos ir } \\
\text { reko- } \\
\text { men- } \\
\text { daci- } \\
\text { jos }\end{array}$ & $\begin{array}{l}\text { darbo } \\
\text { struk- } \\
\text { tūra ir } \\
\text { pagrin- } \\
\text { dines } \\
\text { jos dalys }\end{array}$ & $\begin{array}{c}\text { citavimo } \\
\text { sistema } \\
\text { ir biblio- } \\
\text { grafinių } \\
\text { šaltinių } \\
\text { sąrašas } \\
\end{array}$ & $\begin{array}{c}\text { teksto } \\
\text { ilius- } \\
\text { travi- } \\
\text { mas }\end{array}$ & \\
\hline 7. & & & $\begin{array}{l}\text { pavadinimas. Renginio vieta, data, organizato- } \\
\text { rius. Rankraštis saugomas: biblioteka, skyrius. } \\
\text { Tyrimo, kurio pagrindu parengtas pranešimas, } \\
\text { pavadinimas, autorius, data. } \\
\text { Pavyzdys****: KAZILIONYTĖ, Vitalija. } \\
\text { Kultüros paveldas Pasvalio rajono bibliotekose: } \\
\text { mokslinio tyrimo „Bibliotekine kraštotyra Panevé- } \\
\text { żio apskrities savivaldybiu viešosiose bibliotekose“ } \\
\text { pagrindu. Skaitytas: Tarptautinè mokslinè kon- } \\
\text { ferencija Kultūros paveldas ir kultūros vadyba } \\
\text { modernioje visuomeneje. Panevėžys, } 2016 \text { m. } \\
\text { kovo } 17 \text { d., Panevěžio kraštotyros muziejus. } \\
\text { Rankraštis saugomas: Pasvalio r. SVB, Krašto } \\
\text { kultūros dokumentavimo centras. Tyrimą atli- } \\
\text { ko Pasvalio r. SVB, } 2014 \text {. }\end{array}$ & & & & & & & & \\
\hline 8. & $\begin{array}{l}\text { Tezès mokslinei } \\
\text { konferencijai }\end{array}$ & & $\begin{array}{l}\text { AUTORIAUS PAVARDĖ, Vardas. Konferencijos } \\
\text { pavadinimas. Konferencijos data, vieta. Išleidi- } \\
\text { mo vieta: leidëjas, metai. Puslapių nuoroda. } \\
\text { Pavyzdys**: KAZILIONYTE, Vitalija. Kul- } \\
\text { tūros paveldas ir kultūros vadyba modernioje } \\
\text { visuomeneje. Panevežys, } 2016 \text { m. kovo } 17 \text { d. } \\
\text { Panevėžys: Panevėžio kraštotyros muziejus, } \\
\text { 2016. p. } 12-14 \text {. }\end{array}$ & & & & & & & & \\
\hline
\end{tabular}




\begin{tabular}{|c|c|c|c|c|c|c|c|c|c|c|c|}
\hline \multirow[b]{3}{*}{$\begin{array}{l}\text { Eil. } \\
\text { Nr. }\end{array}$} & \multirow[b]{3}{*}{ Darbo rezultatas } & \multirow{3}{*}{$\begin{array}{c}\text { Savival- } \\
\text { dybès } \\
\text { viešoji } \\
\text { biblio- } \\
\text { teka } \\
\text { (siste- } \\
\text { ma) }\end{array}$} & \multirow[b]{3}{*}{$\begin{array}{l}\text { Darbui identifikuoti reikalingi duomenys } \\
\text { (bibliografinio aprašo forma): autorius, pava- } \\
\text { dinimas, išleidimo vieta, leidèjas, publikavimo } \\
\text { šaltinis, apimtis ir kt. duomenys }\end{array}$} & \multicolumn{8}{|c|}{ Darbo vertinimas balais (nuo 0 iki 5 pagal vertinimo kriterijus) } \\
\hline & & & & \multicolumn{4}{|c|}{\begin{tabular}{|c|} 
Darbo parengimas ir mokslinis \\
(dalykinis) išbaigtumas
\end{tabular}} & \multicolumn{3}{|c|}{$\begin{array}{c}\text { Darbo ifforminimo } \\
\text { kokybe }\end{array}$} & \multirow[b]{2}{*}{$\begin{array}{c}\text { ben- } \\
\text { dras } \\
\text { verti- } \\
\text { nimas } \\
\text { (ba- } \\
\text { lais) }\end{array}$} \\
\hline & & & & \begin{tabular}{|c|} 
temos \\
parinki- \\
mas ir \\
problemos \\
pagrindi- \\
mas
\end{tabular} & \begin{tabular}{|c|} 
\\
me- \\
todi- \\
ka \\
\end{tabular} & \begin{tabular}{|c|} 
problemos \\
analizés koky- \\
bé, mokslinis \\
(dalykinis) \\
pagrindimas
\end{tabular} & $\begin{array}{l}\text { išva- } \\
\text { dos ir } \\
\text { reko- } \\
\text { men- } \\
\text { daci- } \\
\text { jos }\end{array}$ & \begin{tabular}{c|} 
darbo \\
struk- \\
tūra ir \\
pagrin- \\
dinès \\
jos dalys
\end{tabular} & \begin{tabular}{|c|} 
citavimo \\
sistema \\
ir biblio- \\
grafinių \\
šaltiniu \\
sąrašas \\
\end{tabular} & $\begin{array}{c}\text { teksto } \\
\text { ilius- } \\
\text { travi- } \\
\text { mas }\end{array}$ & \\
\hline 9. & $\begin{array}{l}\text { Mokslinių ren- } \\
\text { ginių organiza- } \\
\text { vimas }\end{array}$ & & $\begin{array}{l}\text { Aprašo šablonas: ORGANIZACIJA. Orga- } \\
\text { nizacijos padalinys. Konferencijos statusas } \\
\text { ir pavadinimas. Konferencijos data, vieta. } \\
\text { Pavyzdys***: MOLĖTU RAJONO SA- } \\
\text { VIVALDYBÉS VIEŠOJI BIBLIOTEKA ir } \\
\text { UTENOS KOLEGIJOS Strateginès plètros } \\
\text { skyrius. Moksline praktine konferencija Viešosios } \\
\text { bibliotekos ir kryptinga suaugusiuju neformalaus } \\
\text { mokymosi pletra. } 2015 \text { vasario } 26 \text { d., Molètai. }\end{array}$ & & & & & & & & \\
\hline 10. & $\begin{array}{l}\text { Organizuo- } \\
\text { ti renginiai: } \\
\text { seminarai, } \\
\text { seminarai- } \\
\text { praktikumai ir } \\
\text { pan.), kuriuose } \\
\text { buvo pristatomi, } \\
\text { aptariami bib- } \\
\text { liotekose atliktų } \\
\text { ar su bibliotekų } \\
\text { veikla susijusių } \\
\text { mokslinių tyri- } \\
\text { mų rezultatai ar }\end{array}$ & & 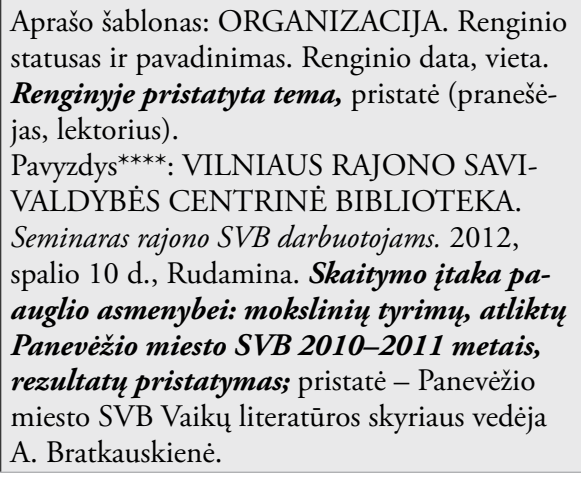 & & & & & & & & \\
\hline
\end{tabular}




\begin{tabular}{|c|c|c|c|c|c|c|c|c|c|c|c|}
\hline \multirow[b]{3}{*}{$\begin{array}{l}\text { Eil. } \\
\text { Nr. }\end{array}$} & \multirow[b]{3}{*}{ Darbo rezultatas } & \multirow{3}{*}{$\begin{array}{c}\text { Savival- } \\
\text { dybès } \\
\text { viešoji } \\
\text { biblio- } \\
\text { teka } \\
\text { (siste- } \\
\text { ma) }\end{array}$} & \multirow[b]{3}{*}{$\begin{array}{l}\text { Darbui identifikuoti reikalingi duomenys } \\
\text { (bibliografinio aprašo forma): autorius, pava- } \\
\text { dinimas, išleidimo vieta, leidejas, publikavimo } \\
\text { šaltinis, apimtis ir kt. duomenys }\end{array}$} & \multicolumn{8}{|c|}{ Darbo vertinimas balais (nuo 0 iki 5 pagal vertinimo kriterijus) } \\
\hline & & & & \multicolumn{4}{|c|}{$\begin{array}{l}\text { Darbo parengimas ir mokslinis } \\
\text { (dalykinis) išbaigtumas }\end{array}$} & \multicolumn{3}{|c|}{$\begin{array}{c}\text { Darbo ifforminimo } \\
\text { kokybe }\end{array}$} & \multirow[b]{2}{*}{$\begin{array}{l}\text { ben- } \\
\text { dras } \\
\text { verti- } \\
\text { nimas } \\
\text { (ba- } \\
\text { lais) }\end{array}$} \\
\hline & & & & $\begin{array}{c}\text { temos } \\
\text { parinki- } \\
\text { mas ir } \\
\text { problemos } \\
\text { pagrindi- } \\
\text { mas }\end{array}$ & $\begin{array}{c}\text { me- } \\
\text { todi- } \\
\mathrm{ka}\end{array}$ & \begin{tabular}{|c|} 
problemos \\
analizės koky- \\
bé, mokslinis \\
(dalykinis) \\
pagrindimas
\end{tabular} & $\begin{array}{l}\text { išva- } \\
\text { dos ir } \\
\text { reko- } \\
\text { men- } \\
\text { daci- } \\
\text { jos }\end{array}$ & $\begin{array}{l}\text { darbo } \\
\text { struk- } \\
\text { tūra ir } \\
\text { pagrin- } \\
\text { dinès } \\
\text { jos dalys }\end{array}$ & \begin{tabular}{|c|} 
citavimo \\
sistema \\
ir biblio- \\
grafinių \\
šaltinių \\
sąrašas \\
\end{tabular} & $\begin{array}{l}\text { teksto } \\
\text { ilius- } \\
\text { travi- } \\
\text { mas }\end{array}$ & \\
\hline & $\begin{array}{l}\text { jų panaudojimo } \\
\text { bibliotekų veik- } \\
\text { los praktikoje } \\
\text { galimybès }\end{array}$ & & & & & & & & & & \\
\hline
\end{tabular}

* Mokslinis aparatas: mokslinés publikacijos dalis, apimanti pagal mokslinius reikalavimus sutvarkytas nuorodas ị kitus mokslo darbus ir šaltinius, įvadą, išnašas, komentarus ir kitą pagalbinę informacija.

** Straipsnis. Registruojami ne mažesnès nei 0,25 autorinio lanko (ne mažiau nei 3 p. 1,5 intervalu „Times New Roman“ 12 dydžio šriftu) apimties su biblioteku veikla susiję analitinio pobūdžio darbai. Mokslinèms publikacijoms gali būti priskiriami tik tie darbai, kurie turi mokslinį aparatą*. Tyrimo tikslams (3 uždavinys) atskirai registruojami straipsniai (Eil. Nr. 6.6), kurie skirti mokslinių darbų, nebūtinai atliktų tik toje konkrečioje bibliotekoje, sklaidai, apibendrinimui, tiesioginiam arba netiesioginiam skatinimui naudotis moksliniais darbais ar jų rezultatais.

*** Recenzuojami žurnalai, sąrašą žr. http://www.mab.lt/lt/istekliai-internete/mokslo-zurnalai.

**** Pavyzdys: lentelèje pateikiami sugalvoti, tikrovèje nesurasti variantai. 


\section{INFORMACINIAI ANALITINIAI DARBAI N APSKRIČIU巳 SAVIVALDYBIŲ VIEŠOSIOSE BIBLIOTEKOSE}

\begin{tabular}{|c|c|c|c|c|c|c|c|c|c|c|c|c|c|c|c|c|c|c|c|}
\hline \multirow{3}{*}{$\begin{array}{c}\text { Darbo } \\
\text { rezul- } \\
\text { tatas }\end{array}$} & \multirow{3}{*}{$\begin{array}{c}\text { Rajono } \\
\text { (miesto) } \\
\text { SVB }\end{array}$} & \multirow{3}{*}{$\begin{array}{l}\text { Savival- } \\
\text { dybès } \\
\text { viešoji } \\
\text { biblio- } \\
\text { teka } \\
\text { (siste- } \\
\text { ma) }\end{array}$} & \multirow{3}{*}{$\begin{array}{l}\text { Darbui identifikuoti } \\
\text { reikalingi duomenys } \\
\text { (bibliografinio aprašo } \\
\text { forma): autorius, pa- } \\
\text { vadinimas, išleidimo } \\
\text { vieta, leidejas, publika- } \\
\text { vimo šaltinis, apimtis } \\
\text { ir kt. duomenys }\end{array}$} & \multicolumn{16}{|c|}{$\begin{array}{c}\text { Darbo ir atskirų sudedamujų jo dalių vertinimas (balais, nuo } 0 \text { iki } 5 \text { balų sistema pagal analitinių ataskaitų vertini- } \\
\text { mo kriterijus, } 5 \text { priedas) }\end{array}$} \\
\hline & & & & \multicolumn{12}{|c|}{ Atskirų bibliotekos veiklos sričių analizės kokybè ir dalykinis pagrindimas } & \multirow{2}{*}{$\begin{array}{l}\text { Išva- } \\
\text { dos, } \\
\text { reko- } \\
\text { men- } \\
\text { daci- } \\
\text { jos ir } \\
\text { pro- } \\
\text { gno- } \\
\text { zès }\end{array}$} & \multicolumn{2}{|c|}{\begin{tabular}{|c|} 
Darbo \\
ifforminimo \\
kokybe
\end{tabular}} & \multirow{2}{*}{$\begin{array}{c}\text { Bendras } \\
\text { vertinimas } \\
\text { (balais): } \\
\text { skai- } \\
\text { čiuojant } \\
\text { vertinimo } \\
\text { vidurki }\end{array}$} \\
\hline & & & & \begin{tabular}{c|} 
I. \\
Ben- \\
droji \\
dalis**
\end{tabular} & \begin{tabular}{|c|} 
II. \\
Biblio- \\
tekų \\
priei- \\
namu- \\
mas
\end{tabular} & \begin{tabular}{|c|} 
III. \\
Fondo \\
forma- \\
vimas
\end{tabular} & \begin{tabular}{|c|} 
IV. \\
Var- \\
totojų \\
aptar- \\
navi- \\
mas
\end{tabular} & \begin{tabular}{|c|} 
V. \\
Vaiku \\
aptar- \\
navi- \\
mas
\end{tabular} & \begin{tabular}{|c|} 
VI. \\
Infor- \\
macinè \\
ir kraš- \\
totyros \\
veikla
\end{tabular} & \begin{tabular}{|c|} 
VII. \\
Meto- \\
dinè \\
veikla \\
\end{tabular} & \begin{tabular}{|c|} 
VIII. \\
Moklsinio \\
tyrimo \\
darbas ir \\
dalyvavi- \\
mas pro- \\
jektuose
\end{tabular} & \begin{tabular}{|c|} 
IX. \\
Žmo- \\
giškieji \\
ište- \\
kliai \\
\end{tabular} & \begin{tabular}{|c|}
$\mathrm{X}$ \\
Mate- \\
rialinè \\
bazé \\
\end{tabular} & \begin{tabular}{|c|} 
XI. \\
Finan- \\
savi- \\
mas \\
\end{tabular} & \begin{tabular}{|c|} 
Kitos \\
ataskaitos \\
dalys, jei \\
yra specia- \\
liai išskir- \\
tos ${ }^{* * *}$
\end{tabular} & & $\begin{array}{c}\text { Darbo } \\
\text { struk- } \\
\text { tūra ir } \\
\text { pagrin- } \\
\text { dinès } \\
\text { jos } \\
\text { dalys }\end{array}$ & $\begin{array}{c}\text { Teksto } \\
\text { ilius- } \\
\text { travi- } \\
\text { mas }\end{array}$ & \\
\hline $\begin{array}{l}\text { Ana- } \\
\text { litinès } \\
\text { apžval- } \\
\text { gos* }\end{array}$ & & & $\begin{array}{l}\text { Aprašo šablonas: AU- } \\
\text { TORIAUS PAVAR- } \\
\text { DE், vardas. Antraštė. } \\
\text { Išleidimo vieta: leidè- } \\
\text { jas, data. }\end{array}$ & & & & & & & & & & & & & & & & \\
\hline $\begin{array}{l}\text { Ana- } \\
\text { litinès } \\
\text { atas- } \\
\text { kaitos }\end{array}$ & $\begin{array}{l}\text { Kelmès r. } \\
\text { SVB }\end{array}$ & & $\begin{array}{l}\text { Aprašo šablonas: AU- } \\
\text { TORIAUS PAVAR- } \\
\text { DĖ, vardas. Antraštė. } \\
\text { Išleidimo vieta: leidè- } \\
\text { jas, data. Ataskaitos } \\
\text { numeris (jeigu yra). } \\
\text { Pvz.: DINAPIENÉ, } \\
\text { Jovita, KANČAUS- } \\
\text { KIENĖ Nijolè, NAVI- } \\
\text { KIENĖ, Virginija. }\end{array}$ & & & & & & & & & & & & & & & & \\
\hline
\end{tabular}




\begin{tabular}{|c|c|c|c|c|c|c|c|c|c|c|c|c|c|c|c|c|c|c|c|}
\hline \multirow{3}{*}{$\begin{array}{c}\text { Darbo } \\
\text { rezul- } \\
\text { tatas }\end{array}$} & \multirow{3}{*}{$\begin{array}{c}\text { Rajono } \\
\text { (miesto) } \\
\text { SVB }\end{array}$} & \multirow{3}{*}{$\begin{array}{l}\text { Savival- } \\
\text { dybès } \\
\text { viešoji } \\
\text { biblio- } \\
\text { teka } \\
\text { (siste- } \\
\text { ma) }\end{array}$} & \multirow{3}{*}{$\begin{array}{c}\text { Darbui identifikuoti } \\
\text { reikalingi duomenys } \\
\text { (bibliografinio aprašo } \\
\text { forma): autorius, pa- } \\
\text { vadinimas, išleidimo } \\
\text { vieta, leidejjas, publika- } \\
\text { vimo šaltinis, apimtis } \\
\text { ir kt. duomenys }\end{array}$} & \multicolumn{16}{|c|}{$\begin{array}{c}\text { Darbo ir atskirų sudedamųju jo dalių vertinimas (balais, nuo } 0 \text { iki } 5 \text { balų sistema pagal analitinių ataskaitų vertini- } \\
\text { mo kriterijus, } 5 \text { priedas) }\end{array}$} \\
\hline & & & & \multicolumn{12}{|c|}{ Atskirų bibliotekos veiklos sričių analizès kokybè ir dalykinis pagrindimas } & \multirow{2}{*}{$\begin{array}{l}\text { Išva- } \\
\text { dos, } \\
\text { reko- } \\
\text { men- } \\
\text { daci- } \\
\text { jos ir } \\
\text { pro- } \\
\text { gno- } \\
\text { zès }\end{array}$} & \multicolumn{2}{|c|}{\begin{tabular}{|c|} 
Darbo \\
ifforminimo \\
kokybè
\end{tabular}} & \multirow{2}{*}{$\begin{array}{c}\text { Bendras } \\
\text { vertinimas } \\
\text { (balais): } \\
\text { skai- } \\
\text { čiuojant } \\
\text { vertinimo } \\
\text { vidurki }\end{array}$} \\
\hline & & & & \begin{tabular}{c|} 
I. \\
Ben- \\
droji \\
dalis**
\end{tabular} & \begin{tabular}{|c|} 
II. \\
Biblio- \\
teku \\
priei- \\
namu- \\
mas
\end{tabular} & \begin{tabular}{|c|} 
III. \\
Fondo \\
forma- \\
vimas \\
\end{tabular} & \begin{tabular}{|c|} 
IV. \\
Var- \\
totoju \\
aptar- \\
navi- \\
mas
\end{tabular} & \begin{tabular}{|c|} 
V. \\
Vaiku \\
aptar- \\
navi- \\
mas \\
\end{tabular} & \begin{tabular}{|c|} 
VI. \\
Infor- \\
macinè \\
ir kraš- \\
totyros \\
veikla
\end{tabular} & \begin{tabular}{|c|} 
VII. \\
Meto- \\
diné \\
veikla \\
\end{tabular} & \begin{tabular}{|c|} 
VIII. \\
Moklsinio \\
tyrimo \\
darbas ir \\
dalyvavi- \\
mas pro- \\
jektuose
\end{tabular} & \begin{tabular}{|c|} 
IX. \\
Žmo- \\
giškieji \\
ište- \\
kliai \\
\end{tabular} & \begin{tabular}{|c|} 
X. \\
Mate- \\
rialiné \\
bazė \\
\end{tabular} & \begin{tabular}{|c|} 
XI. \\
Finan- \\
savi- \\
mas \\
\end{tabular} & $\begin{array}{c}\text { Kitos } \\
\text { ataskaitos } \\
\text { dalys, jei } \\
\text { yra specia- } \\
\text { liai išskir- } \\
\text { tos } \\
\text { t*** }\end{array}$ & & $\begin{array}{c}\text { Darbo } \\
\text { struk- } \\
\text { tūra ir } \\
\text { pagrin- } \\
\text { dinès } \\
\text { jos } \\
\text { dalys }\end{array}$ & \begin{tabular}{|c|} 
\\
Teksto \\
ilius- \\
travi- \\
mas
\end{tabular} & \\
\hline & & & $\begin{array}{l}\text { Kelmès rajono savival- } \\
\text { dybės Žemaitės viešo- } \\
\text { sios bibliotekos } 2015 \\
\text { metų veiklos ataskaita. } \\
\text { Kelmė: Kelmės rajono } \\
\text { savivaldybès Žemaitės } \\
\text { viešoji b-ka, } 2016 . \\
\text { Nr. MA-27. }\end{array}$ & & & & & & & & & & & & & & & & \\
\hline
\end{tabular}

* Savivaldybių viešujų bibliotekų pateikiamus darbus rekomenduojama priskirti analitinių ataskaitų kategorijai ir ịvertinti juos pagal šiems darbams keliamus reikalavimus. Kai parengtas darbas visiškai atitinka analitinès ap̌̌valgos kriterijus (žr. žanro apibūdinimą 4 priede), tokie darbai įregistruojami šiame duomenų blanke, tačiau pagal analitinių ataskaitų kriterijus nevertinami.

** Vertinant Bendrosios dalies parengimo kokybę, pagrindiniu kriterijumi laikyti 5 priede nurodytą kriterijų „Prioritetinių veiklos tikslų ir uždavinių nustatymas ir identifikavimas dokumente".

*** Šioje dalyje vertinamos tik itin reikšmingos, papildomai pateiktos ataskaitoje darbo dalys, kurios yra svarbios tų metų bibliotekos veiklos vertinimui. 


\section{MOKSLO TIRIAMOSIOS VEIKLOS ORGANIZAVIMAS N SAVIVALDYBĖS VIEŠOJOJE BIBLIOTEKOJE}

Gerbiama(-s) direktore (-iau),

[apskrities viešosios bibliotekos tyrejas parašo kreipimosi teksta, kuriame paprašo surašyti reikiamus duomenis pagal pateikta pavyzdį; jeigu mano, kad reikia, parašo papildomus paaiškinimus, kaip pildyti lentele]

\begin{tabular}{|c|c|c|c|c|}
\hline \multirow[b]{2}{*}{ Eil. Nr. } & \multirow[b]{2}{*}{ Dokumento pavadinimas } & \multirow{2}{*}{\begin{tabular}{|c|} 
Žyma: \\
„yra“ arba \\
„nèra“ re- \\
glamentuota \\
moksline \\
(tiriamoji) \\
veikla \\
\end{tabular}} & \multicolumn{2}{|c|}{$\begin{array}{l}\text { Detalūs vadybiniai sprendimai: } \\
\text { kam pavesta veikla ir atsakomybès laipsnis }\end{array}$} \\
\hline & & & Pareigybès pavadinimas & $\begin{array}{c}\text { Atsakomybès laipsnis: organizuoja, } \\
\text { atsako, organizuoja ir atsako, koor- } \\
\text { dinuoja, organizuoja ir koordinuoja, } \\
\text { vykdo, dalyvauja ir pan. }\end{array}$ \\
\hline 7.1. & Bibliotekos veiklos nuostatai: & & & \\
\hline 7.1.1. & $\begin{array}{l}\mathrm{N} \text { viešosios bibliotekos veiklos nuostatai, patvirtinti .......... } \\
\text { (data) direktoriaus ịsakymu Nr. ... }\end{array}$ & Yra & $\begin{array}{l}\text { Direktoriaus pavaduotojas } \\
\text { (jeigu pavedimai ir atsako- } \\
\text { mybes laipsnis yra ịrašyti } \\
\text { viešosios bibliotekos veiklos } \\
\text { nuostatuose) }\end{array}$ & $\begin{array}{l}\text { Organizuoja, koordinuoja ir atsako, } \\
\text { sudaro darbuotojų darbo grupes, } \\
\text { paskirsto darbus }\end{array}$ \\
\hline 7.2. & Atskirų struktūrinių padalinių veiklos nuostatai: & & & \\
\hline 7.2 .1 & $\begin{array}{l}\text { N savivaldybes Skaitytoju aptarnavimo skyriaus veiklos } \\
\text { nuostatai: patvirtinti ............... (data) direktoriaus įsaky- } \\
\text { mu Nr. ... }\end{array}$ & Yra & & $\begin{array}{l}\text { Organizuoja ir vykdo, koordinuoja } \\
\text { ir atsako }\end{array}$ \\
\hline 7.2.1.1. & $\begin{array}{l}\mathrm{N} \text { savivaldybės Skaitytojų aptarnavimo skyriaus vyresniojo } \\
\text { bibliotekininko pareiginiai nuostatai: patvirtinti .............. } \\
\text { (data) direktoriaus įsakymu Nr. ... }\end{array}$ & & Vyresnysis bibliotekininkas & Organizuoja ir vykdo \\
\hline
\end{tabular}




\begin{tabular}{|c|c|c|c|c|}
\hline \multirow[b]{2}{*}{ Eil. Nr. } & \multirow[b]{2}{*}{ Dokumento pavadinimas } & \multirow{2}{*}{$\begin{array}{c}\text { Žyma: } \\
\text { „yra“ arba } \\
\text { „nèra“ re- } \\
\text { glamentuota } \\
\text { moksline } \\
\text { (tiriamoji) } \\
\text { veikla }\end{array}$} & \multicolumn{2}{|c|}{$\begin{array}{l}\text { Detalūs vadybiniai sprendimai: } \\
\text { kam pavesta veikla ir atsakomybès laipsnis }\end{array}$} \\
\hline & & & Pareigybės pavadinimas & $\begin{array}{l}\text { Atsakomybès laipsnis: organizuoja, } \\
\text { atsako, organizuoja ir atsako, koor- } \\
\text { dinuoja, organizuoja ir koordinuoja, } \\
\text { vykdo, dalyvauja ir pan. }\end{array}$ \\
\hline 7.2.1.2 & $\begin{array}{l}\mathrm{N} \text { savivaldybès Skaitytojų aptarnavimo skyriaus vyresniojo } \\
\text { bibliotekininko pareiginiai nuostatai: patvirtinti .............. } \\
\text { (data) direktoriaus i̊sakymu Nr. ... }\end{array}$ & & Vyresnysis bibliotekininkas & Dalyvauja \\
\hline 7.2.2. & $\begin{array}{l}\text { N rajono savivaldybes Informacijos skyriaus veiklos } \\
\text { nuostatai: patvirtinti .............. (data) direktoriaus ịsaky- } \\
\text { mu Nr. ... }\end{array}$ & Yra & & Dalyvauja \\
\hline 7.2.2.1. & $\begin{array}{l}\mathrm{N} \text { rajono savivaldybès Informacijos skyriaus vyresniojo bi- } \\
\text { bliografo pareiginiai nuostatai: patvirtinti ............... (data) } \\
\text { direktoriaus ịsakymu Nr. ... }\end{array}$ & & Vyresnysis bibliografas & Organizuoja ir vykdo \\
\hline 7.2.2.2. & $\begin{array}{l}\mathrm{N} \text { rajono savivaldybès Informacijos skyriaus bibliotekinin- } \\
\text { ko pareiginiai nuostatai: patvirtinti ............... (data) direk- } \\
\text { toriaus įsakymu Nr. ... }\end{array}$ & & Bibliotekininkas & Organizuoja ir vykdo \\
\hline \multicolumn{5}{|c|}{$x^{2}$} \\
\hline \multicolumn{5}{|l|}{ 7.2.3.1. } \\
\hline \multicolumn{5}{|l|}{....... } \\
\hline \multicolumn{5}{|l|}{ 7.2.4. } \\
\hline 7.3. & $\begin{array}{l}\text { Administracijos struktūroms arba tiesiogiai direktoriui } \\
\text { pavaldžios pareigybès (kai veikla ir jos atsakomybès } \\
\text { laipsnis nustatytas tik tos pareigybès veiklai skirtame } \\
\text { dokumente) }\end{array}$ & & & \\
\hline
\end{tabular}




\begin{tabular}{|c|c|c|c|c|}
\hline \multirow[b]{2}{*}{ Eil. Nr. } & \multirow[b]{2}{*}{ Dokumento pavadinimas } & \multirow{2}{*}{\begin{tabular}{|c|} 
Žyma: \\
„yra“ arba \\
„nèra“" re- \\
glamentuota \\
moksliné \\
(tiriamoji) \\
veikla \\
\end{tabular}} & \multicolumn{2}{|c|}{$\begin{array}{l}\text { Detalūs vadybiniai sprendimai: } \\
\text { kam pavesta veikla ir atsakomybès laipsnis }\end{array}$} \\
\hline & & & Pareigybès pavadinimas & $\begin{array}{c}\text { Atsakomybès laipsnis: organizuoja, } \\
\text { atsako, organizuoja ir atsako, koor- } \\
\text { dinuoja, organizuoja ir koordinuoja, } \\
\text { vykdo, dalyvauja ir pan. }\end{array}$ \\
\hline 7.3.1. & $\begin{array}{l}\mathrm{N} \text { rajono savivaldybės viešosios bibliotekos direktoriaus } \\
\text { pavaduotojo pareiginiai nuostatai, patvirtinti ............... } \\
\text { (data) direktoriaus įsakymu Nr. ... }\end{array}$ & Yra & Direktoriaus pavaduotojas & Organizuoja, koordinuoja ir atsako \\
\hline 7.3.2. & $\begin{array}{l}\mathrm{N} \text { rajono savivaldybės viešosios bibliotekos vyresniojo me- } \\
\text { todininko pareiginiai nuostatai, patvirtinti ............... (data) } \\
\text { direktoriaus įsakymu Nr. ... }\end{array}$ & Yra & Vyresnysis metodininkas & Organizuoja ir vykdo \\
\hline 7.3.3. & & & & \\
\hline 7.3.4. & & & & \\
\hline 7.3.5. & & & & \\
\hline 7.3.6. & & & & \\
\hline$\ldots$. & & & & \\
\hline
\end{tabular}




\section{MOKSLO TIRIAMOSIOS VEIKLOS ORGANIZAVIMAS N SAVIVALDYBĖS VIEŠOJOJE BIBLIOTEKOJE}

\section{Personalo, dalyvaujančio šioje veikloje, charakteristikos}

\begin{tabular}{|c|c|c|c|c|c|c|c|c|c|c|c|c|c|c|}
\hline \multirow{5}{*}{$\begin{array}{l}\text { Darbuotojo darbo vieta } \\
\text { (struktūrinis padalinys) }\end{array}$} & \multirow{5}{*}{ Pareigybè } & \multirow{5}{*}{$\begin{array}{l}\text { Darbuotojo } \\
\text { funkcijos } \\
\text { (organizuoja, } \\
\text { atsako, ko- } \\
\text { ordinuoja, } \\
\text { vykdo*, } \\
\text { dalyvauja** ir } \\
\text { pan.) }\end{array}$} & \multirow{5}{*}{$\begin{array}{c}\text { Skiria darbo } \\
\text { laiko***: } \\
\text { (1,00 VEE; } \\
0,50 \mathrm{VEE} ; \\
0,25 \mathrm{VEE} ; \\
<0,25 \mathrm{VEE} ; \\
\mathbf{N})\end{array}$} & \multicolumn{11}{|c|}{ Darbuotojo, šiuo metu einančio šias pareigas, duomenys } \\
\hline & & & & \multicolumn{7}{|c|}{ Išsimokslinimas $* * * * *$} & \multicolumn{3}{|c|}{$\begin{array}{l}\text { Darbo stažas } \\
\text { (pilni metai) }\end{array}$} & \multirow{4}{*}{ 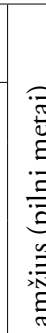 } \\
\hline & & & & \multicolumn{2}{|c|}{ specialusis } & \multicolumn{5}{|c|}{ kitos srities } & \multirow{3}{*}{ 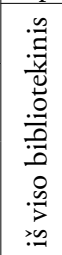 } & \multirow{3}{*}{$\begin{array}{l}\frac{0}{0} \\
\frac{0}{0} \\
\frac{0}{0} \\
\frac{0}{0} \\
. \frac{0}{0} \\
\text { ia }\end{array}$} & \multirow{3}{*}{ 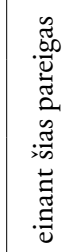 } & \\
\hline & & & & \multirow[b]{2}{*}{ 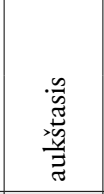 } & \multirow{2}{*}{ 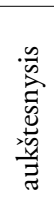 } & \multicolumn{2}{|r|}{ aukštasis } & \multicolumn{2}{|c|}{$\begin{array}{c}\text { aukštes- } \\
\text { nysis }\end{array}$} & & & & & \\
\hline & & & & & & 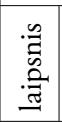 & sritis $* * * *$ & 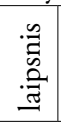 & 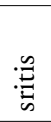 & 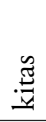 & & & & \\
\hline Informacijos skyrius & Vyresn. bibliotekininkas & Vykdo & $\mathrm{N}$ & $M /-95$ & & & & & & & 15 & 7 & 3 & 55 \\
\hline Vaikų literatūros skyrius & Vyresn. bibliotekininkas & Vykdo & $\mathrm{N}$ & & S & & & & & & 25 & 15 & 15 & 60 \\
\hline $\begin{array}{l}\text { Skaitytojų aptarnavimo } \\
\text { skyrius }\end{array}$ & Vyresn. bibliotekininkas & Vykdo & $\mathrm{N}$ & & & M & $\begin{array}{l}\text { Viešasis admi- } \\
\text { nistravimas }\end{array}$ & & & & 3 & 3 & 3 & 36 \\
\hline Administracija & Direktoriaus pavaduotojas & Organizuoja & $-0,25 \mathrm{VEE}$ & & & B & Filologija & & & & 5 & 3 & 3 & 45 \\
\hline
\end{tabular}

* Vykdo: funkcija registruojama tokiu atveju, kai pareigybei pavesta savarankiškai atlikti visus su tyrimu susijusius darbus, t. y. parengti konkretaus tyrimo programą, parengti dokumentus, nustatyti imti, surinkti ir apibendrinti gautus duomenis, parengti tyrimo ataskaitą ir t. t.

** Dalyvauja: funkcija registruojama tokiu atveju, kai pareigybei pavedama atlikti dalị su bet kuriuo iš atliekamų tyrimų susijusių darbų, pvz., parengti anketą, surinkti ir apibendrinti jos duomenis, arba parengti tą tyrimo dali, kuriai bus naudojami kiekybiniai tyrimo metodai, surinkti šiuos duomenis ir juos apibendrinti ir t. t., ir pan.

*** Darbo laikas fiksuojamas tik tokiu atveju, kai jis realiai skaičiuojamas, o darbo laiko ištekliai moksliniam darbui nurodomi bibliotekos veiklą reglamentuojančiuose dokumentuose; $\mathrm{N}$ raide žymima, kai tokie laiko ištekliai neskaičiuojami.

**** Išsimokslinimo sritys nurodomos pagal ịrašus konkretaus asmens kvalifikacijos lygị patvirtinančiuose dokumentuose. 


\section{Išsimokslinimo ir kvalifikacinio lygmens registravimo kodai}

\begin{tabular}{|c|c|c|}
\hline 1. Specialusis išsimokslinimas: & Kodas & Kvalifikacinis lygis \\
\hline \multicolumn{3}{|l|}{ 1.1. Aukštasis specialusis išsimokslinimas } \\
\hline Aukštos kvalifikacijos bibliotekininko ir bibliografo studijų programa (iki 1995 m., universitetinė, 5 metai) & M/-95 & \\
\hline $\begin{array}{l}\text { Bibliotekininkystés, informacijos (ar) komunikacijos krypties bakalauro studiju programa aukštojoje universiteti- } \\
\text { nèje mokykloje }\end{array}$ & B & Bakalauras \\
\hline $\begin{array}{l}\text { Bibliotekininkystès, informacijos (ar) komunikacijos krypties magistro studijų programa aukštojoje universiteti- } \\
\text { nèje mokykloje }\end{array}$ & M & Magistras \\
\hline \multicolumn{3}{|l|}{ 1.2. Aukštesnysis specialusis išsimokslinimas } \\
\hline $\begin{array}{l}\text { 1.2.1. Bibliotekininkystès, informacijos (ar) komunikacijos krypties studiju programa aukštojoje neuniversiteti- } \\
\text { neje mokykloje }\end{array}$ & PB & Profesinis bakalauras \\
\hline 1.2.2. Specialioji (kultūros) mokykla, bibliotekininkystès ir bibliografijos specialybè (iki $1995 \mathrm{~m}$.) & S & Specialistas \\
\hline \multicolumn{3}{|l|}{ 2. Kitos srities (ne bibliotekinis) išsimokslinimas } \\
\hline \multicolumn{3}{|l|}{ 2.1. Aukštasis išsimokslinimas } \\
\hline 2.1.1. Universitetinè (5 metu) bet kurios krypties trukmès studijų programa (iki $1995 \mathrm{~m}$.) & M/-95 & \\
\hline 2.1.2. Universitetinè bet kurios krypties studijų programa (po $1995 \mathrm{~m}$.) & B & Bakalauras \\
\hline 2.1.3. Universitetinè bet kurios krypties studijų programa (po $1995 \mathrm{~m}$.) & M & Magistras \\
\hline 2.1.4. Pastaba: jei darbuotojas yra ịgijęs sociologijos bakalauro kvalifikacinị laipsnị & Bsoc & Sociologijos bakalauras \\
\hline 2.1.5. Jei darbuotojas yra ịgijęs sociologijos magistro kvalifikacinị laipsnị & Msoc & Sociologijos magistras \\
\hline 2.1.6. Bet kurios krypties studiju programa neuniversitetinèje aukštojoje mokykloje (po 1995 m.) & PB & Profesinis bakalauras \\
\hline 2.1.7. Pastaba: jei darbuotojas yra ịgijęs sociologijos profesinị bakalauro kvalifikacinị laipsnị & PBsoc & $\begin{array}{l}\text { Sociologijos profesinis } \\
\text { bakalauras }\end{array}$ \\
\hline
\end{tabular}


Išsimokslinimo ir kvalifikacinio lygmens registravimo kodai

2.2. Aukštesnysis išsimokslinimas

2.2.1. Bet kurios krypties studiju programa technikume ar jam prilygintoje kitoje aukštesniojoje mokykloje (iki $1995 \mathrm{~m}$.

2.3. Kitas išsimokslinimas

2.3.1. Žemesnio nei technikumo lygmens (iki 1995 m.) ir bendrojo lavinimo programa mokykloje

Specialistas

\begin{tabular}{|l|l|}
\hline S & Specialistas \\
\hline BV & Bendrasis vidurinis
\end{tabular}




\section{SAVIVALDYBIŲ VIEŠŲJŲ BIBLIOTEKŲ MOKSLO DARBŲ VERTINIMO KRITERIJŲ LENTELE்}

\begin{tabular}{|c|c|c|c|c|c|c|}
\hline Kriterijus & O balų & 1 balas & 2 balai & 3 balai & 4 balai & 5 balai \\
\hline $\begin{array}{l}\text { Temos pasi- } \\
\text { rinkimas ir } \\
\text { problemos pa- } \\
\text { grindimas }\end{array}$ & $\begin{array}{l}\text { Pasirinkta atsitikti- } \\
\text { nè tema arba reikš- } \\
\text { minga tik pačiam } \\
\text { tyrejui asmeniškai; } \\
\text { problema neat- } \\
\text { skleista. }\end{array}$ & $\begin{array}{l}\text { Pasirinkta ne- } \\
\text { reikšminga ir (ar) } \\
\text { neaktuali tema, } \\
\text { suformuluota } \\
\text { problema neatspindi } \\
\text { realių [bibliotekos] } \\
\text { poreikių. }\end{array}$ & $\begin{array}{l}\text { Pasirinkta jau išty- } \\
\text { rinėta tema; sufor- } \\
\text { muluota problema } \\
\text { nepagrindžia tyrimo } \\
\text { tikslo ir uždavinių. }\end{array}$ & $\begin{array}{l}\text { Pasirinkta netinkama } \\
\text { (daugelio tyrinėta } \\
\text { arba neatitinkanti } \\
\text { turimų galimybiu) } \\
\text { tema; iki galo nesu- } \\
\text { vokta ir neatskleista } \\
\text { arba nepakankamai } \\
\text { pagrịsta problema. }\end{array}$ & $\begin{array}{l}\text { Pasirinkta tinkama } \\
\text { (aktuali, mažai tyri- } \\
\text { nėta arba netyrinėta) } \\
\text { tema. Gerai suvokta, } \\
\text { atskleista ir pagrįsta } \\
\text { problema. Galimi } \\
\text { nenuoseklumai ir } \\
\text { smulkios loginės klai- } \\
\text { dos pristatant temą } \\
\text { ir (ar) pagrindžiant } \\
\text { problemą. }\end{array}$ & $\begin{array}{l}\text { Pasirinkta aktuali } \\
\text { ir svarbi biblio- } \\
\text { tekai (ar visam } \\
\text { sektoriui) tema, } \\
\text { tinkamai atskleis- } \\
\text { ta problema, ji } \\
\text { siejama su darbo } \\
\text { tikslais ir užda- } \\
\text { viniais bei darbe } \\
\text { suformuluotomis } \\
\text { išvadomis ir reko- } \\
\text { mendacijomis. }\end{array}$ \\
\hline Metodika & $\begin{array}{l}\text { Metodika nenuro- } \\
\text { dyta arba nurodyta } \\
\text { metodika nelogiška } \\
\text { tyrimo tikslo at- } \\
\text { žvilgiu. }\end{array}$ & $\begin{array}{l}\text { Daugybinės metodi- } \\
\text { kos klaidos, kurios } \\
\text { iškraipo rezultatus ir } \\
\text { išvadas. } \\
\text { Prie šių klaidų } \\
\text { priskirtina ir darbe } \\
\text { pateikta per maža } \\
\text { imtis. }\end{array}$ & $\begin{array}{l}\text { Šiurkščios klaidos } \\
\text { pasirenkant tyrimo } \\
\text { metodus; akivaizdu, } \\
\text { kad taikant šią me- } \\
\text { todiką tyrimo tikslai } \\
\text { bus nepasiekti arba } \\
\text { pasiekti tik iš dalies. }\end{array}$ & $\begin{array}{l}\text { Neišsamiai nurodyta } \\
\text { metodika; neišsamiai } \\
\text { nurodytos metodikos } \\
\text { dalys, todèl negalima } \\
\text { iki galo suvokti dar- } \\
\text { bo rezultatų. }\end{array}$ & $\begin{array}{l}\text { Metodika tikslo ir už- } \\
\text { davinių atžvilgiu pasi- } \\
\text { rinkta tinkamai, tačiau } \\
\text { ją galima tobulinti, tai } \\
\text { leistų gauti objektyves- } \\
\text { nius rezultatus. }\end{array}$ & $\begin{array}{l}\text { Pasirinkti patys } \\
\text { optimaliausi me- } \\
\text { todai; taikyti tin- } \\
\text { kami statistiniai } \\
\text { metodai; pateikta } \\
\text { metodika visiškai } \\
\text { panaudota. }\end{array}$ \\
\hline
\end{tabular}




\begin{tabular}{|c|c|c|c|c|c|c|}
\hline Kriterijus & O balų & 1 balas & 2 balai & 3 balai & 4 balai & 5 balai \\
\hline $\begin{array}{l}\text { Problemos ana- } \\
\text { lizès kokybe், } \\
\text { mokslinis (da- } \\
\text { lykinis) pagrin- } \\
\text { dimas }\end{array}$ & $\begin{array}{l}\text { Problema išanali- } \\
\text { zuota nenuosekliai } \\
\text { arba darbe nepaiso- } \\
\text { ma pasirinktos me- } \\
\text { todikos; duomenu } \\
\text { analizė nekokybiš- } \\
\text { ka arba analizuo- } \\
\text { jami nereikšmingi } \\
\text { duomenys; darbas } \\
\text { neturi jokios moks- } \\
\text { linès (ir praktinès) } \\
\text { vertès. }\end{array}$ & $\begin{array}{l}\text { Problema išanali- } \\
\text { zuota nenuosekliai ir } \\
\text { neaiškiai, nėra sąsaju } \\
\text { tarp atskirų darbo } \\
\text { struktūrinių dalių; } \\
\text { prastai parengta } \\
\text { ìvadinè dalis, labai } \\
\text { netolygiai pristatytos } \\
\text { kitos darbo dalys; } \\
\text { daug loginių klaidu } \\
\text { ir netikslumu, dide- } \\
\text { les klaidos pateikiant } \\
\text { rezultatus. }\end{array}$ & $\begin{array}{l}\text { Nebaigtas darbas. } \\
\text { Iki galo nesuprasta } \\
\text { ir pristatyta darbo } \\
\text { tematika, silpnai } \\
\text { pristatyti darbo } \\
\text { rezultatai. } \\
\text { Didelès klaidos } \\
\text { analizuojant duo- } \\
\text { menis (pasirinkti } \\
\text { ne tie duomenys, } \\
\text { jie netinkamai ap- } \\
\text { dorojami, gali pasi- } \\
\text { taikyti elementarių } \\
\text { skaičiavimo klaidų } \\
\text { ir pan.). }\end{array}$ & $\begin{array}{l}\text { Tinkamai pristatyta ir } \\
\text { išanalizuota pagrindine } \\
\text { tema (problema). Ga- } \\
\text { limi trūkumai pasiren- } \\
\text { kant kalbos stilių (ne } \\
\text { visada paisoma akade- } \\
\text { minio raštingumo rei- } \\
\text { kalavimu); neišsamiai } \\
\text { pateikiami rezultatai } \\
\text { arba daug perteklinių } \\
\text { duomenu, kurie truk- } \\
\text { do tinkamai atskleisti } \\
\text { esminius darbo rezul- } \\
\text { tatus. Galimi trūkumai } \\
\text { aptariant atskiras temas } \\
\text { ar potemius (gali būti } \\
\text { aptarta neišsamiai ir } \\
\text { (ar) fragmentiškai). }\end{array}$ & $\begin{array}{l}\text { Darbe nuosekliai iš- } \\
\text { analizuota pasirinkta } \\
\text { tema; tinkamai surink- } \\
\text { ti ir panaudoti duome- } \\
\text { nys, pasirinkti patikimi } \\
\text { argumentai darbo } \\
\text { rezultatams atskleisti. } \\
\text { Darbas turi aišku adre- } \\
\text { sata, gauti rezultatai } \\
\text { gali būti naudingi } \\
\text { bibliotekos (-u) veiklos } \\
\text { praktikai. }\end{array}$ & $\begin{array}{l}\text { Darbe aiškiai, susis- } \\
\text { temintai ir akivaiz- } \\
\text { džiai atskleistas jo } \\
\text { tikslas, uždaviniai } \\
\text { ir rezultatai. Duo- } \\
\text { menys pagrindžia } \\
\text { išvadas, darbas yra } \\
\text { naudingas ir jo } \\
\text { rezultatai (išvados } \\
\text { ir (ar) rekomen- } \\
\text { dacijos) gali būti } \\
\text { pritaikytos prakti- } \\
\text { nëje veikloje [arba } \\
\text { atskleidžia reikšmin- } \\
\text { gus biblioteku prak- } \\
\text { tikai dèsningumus, } \\
\text { jei darbas daugiau } \\
\text { teorinio pobüdžio]. }\end{array}$ \\
\hline $\begin{array}{l}\text { Išvados ir reko- } \\
\text { mendacijos }\end{array}$ & $\begin{array}{l}\text { Neparengtos nei } \\
\text { išvados, nei reko- } \\
\text { mendacijos. }\end{array}$ & $\begin{array}{l}\text { Išvados menkai sie- } \\
\text { jasi su darbo tikslu } \\
\text { ir uždaviniais; for- } \\
\text { muluotès netikslios, } \\
\text { o turinys nereikš- } \\
\text { mingas. }\end{array}$ & $\begin{array}{l}\text { Išvados (ar re- } \\
\text { komendacijos) } \\
\text { suformuluotos } \\
\text { nepagrįstai, neati- } \\
\text { tinka analizuojamų } \\
\text { duomenų arba } \\
\text { jiems prieštarauja; } \\
\text { rekomendacijos pa- } \\
\text { viršutiniškos, neturi } \\
\text { adresato arba yra } \\
\text { neigyvendinamos ar } \\
\text { nelogiškos. }\end{array}$ & $\begin{array}{l}\text { Išvados tik iš dalies } \\
\text { atitinka darbe spren- } \\
\text { džiamas problemas; } \\
\text { nevisiškai atitinka } \\
\text { uždavinius ar nevisiš- } \\
\text { kai patenkina tikslą. } \\
\text { Rekomendacijos (jei- } \\
\text { gu jos yra) deklaraty- } \\
\text { vios (pvz., „gerinti“, } \\
\text { „tobulinti“ ir pan.), } \\
\text { bet nenurodančios, } \\
\text { kaip tai daryti. }\end{array}$ & \begin{tabular}{|l|} 
Išvados susietos su \\
darbo problema ir jame \\
sprendžiamais uždavi- \\
niais; rekomendacijos \\
tinkamos ir praktiškai \\
igyvendinamos. \\
Galimi nereikšmingi \\
išvadų ir rekomenda- \\
cijų formuluočių trū- \\
kumai (pvz., gali būti \\
tam tikrų neesminių \\
pasikartojimų, kurie \\
gali turetti perteklinès \\
informacijos ir pan.).
\end{tabular} & $\begin{array}{l}\text { Išvados tikslios ir } \\
\text { glaustos, aiškiai } \\
\text { susietos su darbo } \\
\text { problema ir jame } \\
\text { sprendžiamais } \\
\text { uždaviniais. Re- } \\
\text { komendacijos } \\
\text { turi aišku adresatą } \\
\text { ir yra praktiškai } \\
\text { igyvendinamos. }\end{array}$ \\
\hline
\end{tabular}




\begin{tabular}{|c|c|c|c|c|c|c|}
\hline Kriterijus & 0 balų & 1 balas & 2 balai & 3 balai & 4 balai & 5 balai \\
\hline $\begin{array}{l}\text { Darbo struktū- } \\
\text { ra ir pagrindi- } \\
\text { nès jo dalys }\end{array}$ & $\begin{array}{l}\text { Darbas visiškai } \\
\text { neturi struktūros. }\end{array}$ & $\begin{array}{l}\text { Darbas nevientisas, } \\
\text { netinkamai pateiktos } \\
\text { pagrindinės struk- } \\
\text { tūros dalys: tikslas, } \\
\text { uždaviniai, rezulta- } \\
\text { tai, išvados. }\end{array}$ & $\begin{array}{l}\text { Darbo dalys tarpu- } \\
\text { savyje neturi loginio } \\
\text { ryšio; darbo rezul- } \\
\text { tatai nepagrindžia } \\
\text { išvadų. }\end{array}$ & $\begin{array}{l}\text { Blogai suformuluotas } \\
\text { tikslas ir uždaviniai, } \\
\text { išvados neatspindi } \\
\text { rezultatų ar nevisiškai } \\
\text { atitinka tikslą. }\end{array}$ & $\begin{array}{l}\text { Visos struktūrinės } \\
\text { mokslinio darbo dalys } \\
\text { logiškai parinktos ir } \\
\text { atskleistos. Galimos } \\
\text { smulkios klaidos, ne- } \\
\text { pažeidžiančios darbo } \\
\text { nuoseklumo ir logikos. }\end{array}$ & $\begin{array}{l}\text { Visos struktūrinès } \\
\text { dalys taisyklingos, } \\
\text { pateikiamos pa- } \\
\text { pildomos žinios, } \\
\text { atlikta (gali būti } \\
\text { nedidelès apim- } \\
\text { ties) nagrinèjamos } \\
\text { temos aktualios li- } \\
\text { teratūros apžvalga. }\end{array}$ \\
\hline $\begin{array}{l}\text { Citavimo siste- } \\
\text { ma ir bibliogra- } \\
\text { finių šaltinių } \\
\text { sąrašas }\end{array}$ & $\begin{array}{l}\text { Nèra citavimo ir } \\
\text { bibliografinių nuo- } \\
\text { rodų sistemos. }\end{array}$ & $\begin{array}{l}\text { Pasirinkta klaidinga } \\
\text { citavimo sistema; yra } \\
\text { esminių klaidų tei- } \\
\text { kiant bibliografinius } \\
\text { aprašus; gali būti, } \\
\text { kad nesilaikoma } \\
\text { jokių žinomų tai- } \\
\text { syklių. }\end{array}$ & $\begin{array}{l}\text { Pasirinkta klaidinga } \\
\text { citavimo sistema; } \\
\text { yra klaidų teikiant } \\
\text { bibliografinius ap- } \\
\text { rašus, nesilaikoma } \\
\text { svarbiausių jiems } \\
\text { taikomų reikala- } \\
\text { vimų. }\end{array}$ & $\begin{array}{l}\text { Yra citavimo klaidų; } \\
\text { cituojama nekorek- } \\
\text { tiškai (dažnai netei- } \\
\text { kiamos nuorodos i } \\
\text { cituojamus tekstus); } \\
\text { yra klaidų teikiant } \\
\text { bibliografinius apra- } \\
\text { šus, nepateikiamos } \\
\text { visos nuorodos. }\end{array}$ & $\begin{array}{l}\text { Pasirinkta tinkama } \\
\text { citavimo ir bibliografi- } \\
\text { nių nuorodų sistema; } \\
\text { gali pasitaikyti nereikš- } \\
\text { mingų netikslumų } \\
\text { (arba korektūros klai- } \\
\text { dų; pvz., punktuacijos, } \\
\text { žodžių trumpinimo ar } \\
\text { pan.). }\end{array}$ & $\begin{array}{l}\text { Pasirinkta tin- } \\
\text { kama citavimo } \\
\text { ir bibliografinių } \\
\text { nuorodų sistema; } \\
\text { bibliografinių } \\
\text { nuorodų sąrašas } \\
\text { sudarytas neprie- } \\
\text { kaištingai. }\end{array}$ \\
\hline $\begin{array}{l}\text { Teksto ilius- } \\
\text { travimas (verti- } \\
\text { nama darbuose, } \\
\text { kuriuose ši dalis } \\
\text { bütina arba } \\
\text { pageidaujama) }\end{array}$ & $\begin{array}{l}\text { Nėra iliustracinès } \\
\text { medžiagos (tuose } \\
\text { darbuose, kuriuose } \\
\text { ši dalis objektyviai } \\
\text { yra būtina). }\end{array}$ & $\begin{array}{l}\text { Lentelès, paveikslai } \\
\text { parengti nekorek- } \\
\text { tiškai, nesisieja su } \\
\text { dèstoma (analizuoja- } \\
\text { ma) tema. Pateikiant } \\
\text { duomenis padaryta } \\
\text { dideliu skaičiavimo } \\
\text { arba ju grafinio vaiz- } \\
\text { davimo klaidų. }\end{array}$ & $\begin{array}{l}\text { Pasirinkti netinkami } \\
\text { lentelių ir grafinio } \\
\text { duomenų vaizda- } \\
\text { vimo modeliai; } \\
\text { duomenys neįskai- } \\
\text { tomi ir (arba) yra } \\
\text { jų skaičiavimo arba } \\
\text { grafinio vaizdavimo } \\
\text { klaidų. }\end{array}$ & $\begin{array}{l}\text { Dalis lentelèse arba } \\
\text { grafiniais vaizdais } \\
\text { darbe teikiamos } \\
\text { informacijos yra } \\
\text { teikiama netinkamai: } \\
\text { pasirinkti ne tie vaiz- } \\
\text { davimo modeliai, yra } \\
\text { smulkių iliustracinès } \\
\text { dalies apipavidalini- } \\
\text { mo klaidu. }\end{array}$ & $\begin{array}{l}\text { Vaizdinė medžiaga } \\
\text { sutvarkyta ir pateikta } \\
\text { kokybiškai ir laikan- } \\
\text { tis visų pagrindinių } \\
\text { reikalavimų; gali būti } \\
\text { smulkių netikslumų } \\
\text { apipavidalinant ilius- } \\
\text { tracinę dalị. }\end{array}$ & $\begin{array}{l}\text { Vaizdinė medžiaga } \\
\text { sutvarkyta ir pa- } \\
\text { teikta kokybiškai, } \\
\text { aiškiai įskaitoma, } \\
\text { laikantis visu } \\
\text { pagrindinių reika- } \\
\text { lavimų. }\end{array}$ \\
\hline
\end{tabular}




\section{ANALITINIŲ ATASKAITŲ* VERTINIMO KRITERIJŲ LENTELE}

\begin{tabular}{|c|c|c|c|c|c|c|}
\hline Kriterijus & 0 balų & 1 balas & 2 balai & 3 balai & 4 balai & 5 balai \\
\hline $\begin{array}{l}\text { Prioriteti- } \\
\text { nių veiklos } \\
\text { tikslų ir } \\
\text { uždavinių } \\
\text { identifikavi- } \\
\text { mas doku- } \\
\text { mente } \\
\text { (pagrindinis } \\
\text { vertinimo } \\
\text { kriterijus } \\
\text { vertinant } \\
\text { ataskaitos } \\
\text { „Bendrosios } \\
\text { dalies“paren- } \\
\text { gimo kokybę) }\end{array}$ & $\begin{array}{l}\text { Neaptariami } \\
\text { atsiskai- } \\
\text { tomaisiais } \\
\text { metais } \\
\text { igyvendinti } \\
\text { pagrindiniai } \\
\text { tikslai ir už- } \\
\text { daviniai. }\end{array}$ & $\begin{array}{l}\text { Aptariami ben- } \\
\text { driausio pobūdžio } \\
\text { bibliotekos tikslai } \\
\text { ir uždaviniai, kurie } \\
\text { buvo igyvendinti } \\
\text { atsiskaitomaisiais } \\
\text { metais. Nepagrịstas } \\
\text { tikslų ir uždavinių } \\
\text { aktualumas ir } \\
\text { tikslingumas: ne- } \\
\text { nurodyti esminiai } \\
\text { prieštaravimai, } \\
\text { su kuriais susi- } \\
\text { dūrè biblioteka } \\
\text { atsiskaitomaisiais } \\
\text { metais, pagrindinès } \\
\text { sprendžiamos prob- } \\
\text { lemos, nenurodyti } \\
\text { arba nurodyti ne- } \\
\text { reikšmingi, nesvar- } \\
\text { būs nacionalinio, } \\
\text { ir (ar) savivaldos } \\
\text { lygmens teisės } \\
\text { aktai, kuriais buvo } \\
\text { remtasi pasirenkant } \\
\text { šiuos tikslus. }\end{array}$ & $\begin{array}{l}\text { Aptariami bendrieji } \\
\text { atsiskaitomaisiais } \\
\text { metais igyvendinti } \\
\text { bibliotekos tikslai ir } \\
\text { uždaviniai, tačiau jų } \\
\text { igyvendinimo ana- } \\
\text { lizè nesusieta nei su } \\
\text { realiais aptarnauja- } \\
\text { mos bendruomenės } \\
\text { poreikiais, nei su } \\
\text { pagrindinėmis šalies } \\
\text { bibliotekų vystymo, } \\
\text { nei savivaldybės } \\
\text { sprendžiamomis } \\
\text { kultūrinėmis ir } \\
\text { socialinėmis proble- } \\
\text { momis. }\end{array}$ & $\begin{array}{l}\text { Aptariami atsiskaito- } \\
\text { maisiais metais igy- } \\
\text { vendinti bibliotekos } \\
\text { tikslai ir uždaviniai, } \\
\text { tačiau jie tik iš dalies } \\
\text { suderinti su naciona- } \\
\text { linėmis, regiono ar } \\
\text { savivaldos vystymo } \\
\text { strategijomis arba } \\
\text { ignoruojami (nemini- } \\
\text { mi) labai svarbūs na- } \\
\text { cionalinio, regioninio } \\
\text { ar savivaldos lygmens } \\
\text { dokumentai, kuriais } \\
\text { remiantis turètų būti } \\
\text { formuojamos bibliote- } \\
\text { kos veiklos strateginès } \\
\text { nuostatos. }\end{array}$ & $\begin{array}{l}\text { Atskleisti prioritetiniai } \\
\text { bibliotekos tikslai ir } \\
\text { uždaviniai igyvendinti } \\
\text { atsiskaitomaisiais me- } \\
\text { tais. Aptarti svarbiausi } \\
\text { nacionalinio, regi- } \\
\text { oninio ir savivaldos } \\
\text { lygmens dokumentai, } \\
\text { arba nurodytos veiklos } \\
\text { kryptys - kuo remian- } \\
\text { tis galima įvertinti, } \\
\text { kaip viešosios biblio- } \\
\text { tekos veikla integruo- } \\
\text { ta šalies, regiono ar } \\
\text { teritorijos vystymo } \\
\text { strategijose. Galimos } \\
\text { tam tikros klaidos: ne } \\
\text { visi uždaviniai susieti } \\
\text { su ankstesnės veiklos } \\
\text { rezultatais, ataskaitoje } \\
\text { suformuluotos išvados } \\
\text { ir rekomendacijos tik } \\
\text { iš dalies susietos su } \\
\text { tais metais igyvendin- } \\
\text { tais tikslais ir uždavi- } \\
\text { niais. }\end{array}$ & $\begin{array}{l}\text { Atskleisti prioritetiniai } \\
\text { bibliotekos tikslai ir už- } \\
\text { daviniai atsiskaitomuoju } \\
\text { laikotarpiu, jie susieti su } \\
\text { ankstesnės veiklos rezul- } \\
\text { tatais, ankstesniaisiais } \\
\text { laikotarpiais išspręs- } \\
\text { tomis (arba neišspręs- } \\
\text { tomis) problemomis, } \\
\text { aiškiai susieti su tais } \\
\text { tikslais ir uždaviniais ir } \\
\text { juos reglamentuojančiais } \\
\text { dokumentais, kurie, } \\
\text { dalyvaujant viešosioms } \\
\text { bibliotekoms, spren- } \\
\text { džiami nacionaliniu, } \\
\text { regioniniu ir savivaldos } \\
\text { lygmeniu. } \\
\text { Ataskaitoje suformuluo- } \\
\text { tos išvados ir rekomen- } \\
\text { dacijos atitinka atsiskai- } \\
\text { tomuoju laikotarpiu } \\
\text { tgyvendintus tikslus ir } \\
\text { uždavinius. }\end{array}$ \\
\hline
\end{tabular}




\begin{tabular}{|c|c|c|c|c|c|c|}
\hline Kriterijus & 0 balu & 1 balas & 2 balai & 3 balai & 4 balai & 5 balai \\
\hline $\begin{array}{l}\text { Atskiru } \\
\text { veiklos sri- } \\
\text { čių analizės } \\
\text { kokybè ir } \\
\text { mokslinis } \\
\text { (dalykinis) } \\
\text { pagrindi- } \\
\text { mas } \\
\text { (vertinimo } \\
\text { principais va- } \\
\text { dovaujamasi } \\
\text { vertinant } \\
\text { kiekvienos } \\
\text { veiklos srities } \\
\text { analize) }\end{array}$ & $\begin{array}{l}\text { Veiklos sritis } \\
\text { neanalizuo- } \\
\text { jama. } \\
\text { Darbe pa- } \\
\text { teikiami tik } \\
\text { atrankiniai, } \\
\text { visumos ne- } \\
\text { atspindintys } \\
\text { duomenys ar } \\
\text { faktai; tekstas } \\
\text { aprašomojo } \\
\text { (atpasakoja- } \\
\text { mojo) pobū- } \\
\text { džio, netei- } \\
\text { kiami jokie } \\
\text { susisteminti } \\
\text { kiekybiniai } \\
\text { duomenys, } \\
\text { palyginimai, } \\
\text { vertinimai. }\end{array}$ & $\begin{array}{l}\text { Veiklos srities ana- } \\
\text { lizė nekokybiška } \\
\text { arba analizuojami } \\
\text { nereikšmingi } \\
\text { duomenys; daug } \\
\text { loginių klaidų ir } \\
\text { netikslumų; paren- } \\
\text { kami duomenys } \\
\text { nesisteminami, } \\
\text { nelyginami arba } \\
\text { lyginami nekorek- } \\
\text { tiškai; pateiktos } \\
\text { informacijos nepa- } \\
\text { kanka, kad galima } \\
\text { būtų suprasti, ko- } \\
\text { kių rezultatų siekė } \\
\text { (ar pasiekè) biblio- } \\
\text { teka analizuojamu } \\
\text { laikotarpiu. Yra } \\
\text { kiekybinių duo- } \\
\text { menų skaičiavimo } \\
\text { ir interpretavimo } \\
\text { klaidų. }\end{array}$ & $\begin{array}{l}\text { Panaudoti atskiri } \\
\text { analizės elementai. } \\
\text { Naudojami teiginiai } \\
\text { ar apibendrinimai } \\
\text { grindžiami ne } \\
\text { duomenu ar faktų } \\
\text { analize ir vertinimu, } \\
\text { o nuomonemis } \\
\text { ar empirine pa- } \\
\text { tirtimi. Aptariant } \\
\text { atskiras veiklos } \\
\text { sritis duomenys } \\
\text { neapdorojami arba } \\
\text { apdorojami netin- } \\
\text { kamai, ju reikšmès } \\
\text { neanalizuojamos ir } \\
\text { neinterpretuojamos } \\
\text { arba analizuojamos } \\
\text { ir interpretuojamos } \\
\text { atsietai nuo tyrinè- } \\
\text { jamos veiklos srities. } \\
\text { Yra nemažai (orien- } \\
\text { tacijai - daugiau } \\
\text { nei } 30 \text { proc. visų } \\
\text { pateiktu statistinių } \\
\text { duomenų rinkinių, } \\
\text { lenteliu ir t. t.) kie- } \\
\text { kybinių duomenų } \\
\text { skaičiavimo ir inter- } \\
\text { pretavimo klaidų. }\end{array}$ & $\begin{array}{l}\text { Veiklos sritis išana- } \\
\text { lizuota tinkamai. } \\
\text { Galimi neesminiai } \\
\text { trūkumai vertinant } \\
\text { ar interpretuojant } \\
\text { atskirus duomenis, } \\
\text { netikslumai nusta- } \\
\text { tant priežastinius ir } \\
\text { pasekminius ryšius, } \\
\text { interpretuojant ir } \\
\text { vertinant darbo re- } \\
\text { zultatus; tam tikri } \\
\text { veiklos aspektai gali } \\
\text { būti aptarti neišsamiai } \\
\text { ir (ar) fragmentiškai. } \\
\text { Esminių duomenų } \\
\text { skaičiavimo, analizės } \\
\text { ir interpretavimo klai- } \\
\text { dų néra. }\end{array}$ & $\begin{array}{l}\text { Veiklos sritis išana- } \\
\text { lizuota tinkamai, } \\
\text { pateikiami analizès } \\
\text { duomenys patikimai } \\
\text { ịrodo, kad analizuo- } \\
\text { jamuoju laikotarpiu } \\
\text { buvo pasiektas (arba } \\
\text { ne) bibliotekos tikslas } \\
\text { ir (arba) igyvendintas } \\
\text { (-i) uždavinys (-iai), } \\
\text { skirtas (-i) tam tikslui } \\
\text { pasiekti. Atskleistos } \\
\text { pagrindinės pokyčių } \\
\text { tendencijos arba } \\
\text { numatyti papildomi } \\
\text { veiksmai siekiant } \\
\text { nustatyti esmines } \\
\text { pozityvių ar negatyvių } \\
\text { pokyčių priežastis. } \\
\text { Gali būti neesminių } \\
\text { trūkumų ar pertekli- } \\
\text { nės informacijos ana- } \\
\text { lizuojant veiklą (pvz., } \\
\text { atskirose darbo dalyse } \\
\text { analizuojama ta pati } \\
\text { veikla). Duomenų } \\
\text { atrankos, skaičiavimo, } \\
\text { analizės ir interpreta- } \\
\text { vimo klaidų nèra. }\end{array}$ & $\begin{array}{l}\text { Visos veiklos sritys iša- } \\
\text { nalizuotos; aiškiai, susis- } \\
\text { temintai ir akivaizdžiai } \\
\text { atskleisti konkrečių vei- } \\
\text { klos sričių rezultatai ir } \\
\text { pateiktas jų vertinimas } \\
\text { pasirinktiems tikslams } \\
\text { ir uždaviniams igyven- } \\
\text { dinti. Tarpinės išvados ir } \\
\text { apibendrinimai pagrịsti } \\
\text { tinkamai pateiktais ir } \\
\text { interpretuotais duome- } \\
\text { nimis, atskleistos anali- } \\
\text { zuojamos veiklos srities } \\
\text { vystymo prognozes ir } \\
\text { (arba) suformuluotos } \\
\text { raidos kryptys ateičiai. } \\
\text { Duomenu atrankos, } \\
\text { skaičiavimo, analizės ir } \\
\text { interpretavimo klaidų } \\
\text { nėra. }\end{array}$ \\
\hline
\end{tabular}




\begin{tabular}{|c|c|c|c|c|c|c|}
\hline Kriterijus & 0 balu & 1 balas & 2 balai & 3 balai & 4 balai & 5 balai \\
\hline $\begin{array}{l}\text { Išvados ir } \\
\text { rekomenda- } \\
\text { cijos }\end{array}$ & $\begin{array}{l}\text { Nèra pareng- } \\
\text { tų nei išvadu, } \\
\text { nei rekomen- } \\
\text { dacijų. }\end{array}$ & $\begin{array}{l}\text { Išvados visiškai } \\
\text { nesiejamos arba tik } \\
\text { iš dalies siejamos su } \\
\text { išdèstyta medžiaga; } \\
\text { išvadų formuluotès } \\
\text { netikslios, o turinys } \\
\text { nereikšmingas. }\end{array}$ & $\begin{array}{l}\text { Išvados suformu- } \\
\text { luotos nepagrisstai, } \\
\text { neatitinka analizuo- } \\
\text { jamu duomenų arba } \\
\text { jiems prieštarauja, } \\
\text { pakartoja pagrindines } \\
\text { įvado tezes arba bib- } \\
\text { liotekos nuostatuose } \\
\text { įvardytus tikslus ir } \\
\text { uždavinius; išvadose } \\
\text { pateikiama nauja, } \\
\text { veiklos analizes dalyje } \\
\text { neatskleista informa- } \\
\text { cija, rekomendacijos } \\
\text { (raidos prognozès, } \\
\text { artimiausios veiklos } \\
\text { kryptys) suformuluo- } \\
\text { tos paviršutiniškai, } \\
\text { yra neigyvendinamos } \\
\text { ar nelogiškos. }\end{array}$ & $\begin{array}{l}\text { Išvados tik iš dalies } \\
\text { atitinka bibliotekos } \\
\text { igyvendinamus tikslus } \\
\text { ir uždavinius, nevisiš- } \\
\text { kai atsako, kaip buvo } \\
\text { išspręsti numatyti už- } \\
\text { daviniai ir (ar) pasiek- } \\
\text { tas numatytas tikslas. } \\
\text { Išvadose fiksuojami ne } \\
\text { rezultatai, o procesai, } \\
\text { pvz.: „darbuotojai } \\
\text { teikia kokybiškas } \\
\text { bibliotekos paslaugas, } \\
\text { kuria informacinę ir } \\
\text { žinių visuomenę, ska- } \\
\text { tina skaitymą ir užti- } \\
\text { krina paslaugas, <...> } \\
\text { gyventojai nuolat mo- } \\
\text { komi kompiuterinio } \\
\text { raštingumo" ir pan. }\end{array}$ & $\begin{array}{l}\text { Išvados susietos su } \\
\text { bibliotekos sufor- } \\
\text { muluotais tikslais ir } \\
\text { sprendžiamais užda- } \\
\text { viniais, jos tikslingos, } \\
\text { logiškos. Prognozès } \\
\text { (jei jos pateikiamos) } \\
\text { remiamos tekstuose } \\
\text { tinkamai išanalizuo- } \\
\text { tais ir apibendrintais } \\
\text { statistiniais, atliktų } \\
\text { tyrimų ar kitokiais } \\
\text { procesiniais ar veiklos } \\
\text { rezultatų vertinimų } \\
\text { duomenimis. }\end{array}$ & $\begin{array}{l}\text { Išvados tikslios ir glaus- } \\
\text { tos, aiškiai susietos su } \\
\text { bibliotekos tikslais ir } \\
\text { sprendžiamais užda- } \\
\text { viniais. Bibliotekos } \\
\text { raidos prognozės arti- } \\
\text { miausiam laikotarpiui } \\
\text { aiškiai suformuluotos, } \\
\text { rekomendacijos (numa- } \\
\text { tomos veiklos kryptys) } \\
\text { pagristos, atitinkančios } \\
\text { moksliškumo ir prak- } \\
\text { tiškumo principus, taip } \\
\text { pat aptarnaujamos ben- } \\
\text { druomenès poreikius } \\
\text { biblioteku paslaugoms } \\
\text { ir praktiškai igyvendi- } \\
\text { namos. }\end{array}$ \\
\hline $\begin{array}{l}\text { Darbo } \\
\text { struktūra ir } \\
\text { pagrindinès } \\
\text { jo dalys }\end{array}$ & $\begin{array}{l}\text { Analitinė } \\
\text { ataskaita vi- } \\
\text { siškai neturi } \\
\text { struktūros }\end{array}$ & $\begin{array}{l}\text { Atskiros veiklos sri- } \\
\text { tys analizuojamos } \\
\text { fragmentiškai. Ats- } \\
\text { kirų veiklos sričiu } \\
\text { analizè akivaizdžiai } \\
\text { nelygiavertè. Dar- } \\
\text { bas iformintas } \\
\text { netinkamai. }\end{array}$ & $\begin{array}{l}\text { Darbo struktūra } \\
\text { nenuosekli, nesuba- } \\
\text { lansuota, nepagrįstai } \\
\text { išsamiai ir detaliai } \\
\text { analizuojamos } \\
\text { (aprašomos, ilius- } \\
\text { truojamos) vienos } \\
\text { veiklos sritys, o kitų } \\
\text { sričių analizè atlikta } \\
\text { paviršutiniškai }\end{array}$ & $\begin{array}{l}\text { Darbo struktūra ir } \\
\text { teksto organizavimas } \\
\text { atitinka pagrindinius } \\
\text { reikalavimus; atskirose } \\
\text { darbo dalyse gali būti } \\
\text { tam tikrų netolygumu } \\
\text { ar netikslumų, tačiau } \\
\text { jie lemiamos ịtakos } \\
\text { veiklos analizei ir } \\
\text { vertinimui nedaro. }\end{array}$ & $\begin{array}{l}\text { Visos struktūrinès } \\
\text { analitinio darbo dalys } \\
\text { logiškai, nuosekliai } \\
\text { išdesstytos, jų turinys } \\
\text { atskleistas remiantis } \\
\text { objektyvia moksliškai } \\
\text { pagrisstu ar praktikoje } \\
\text { patikrintų ir patikimų } \\
\text { duomenų ir šiu duo- } \\
\text { menų pagrindu gautų }\end{array}$ & $\begin{array}{l}\text { Yra visos struktūrinės da- } \\
\text { lys, reikalingos analizuo- } \\
\text { jamai temai (problemai) } \\
\text { iš esmès ištirti, kiekviena } \\
\text { sudètinè veiklos sritis } \\
\text { tinkamai atskleista (giliai, } \\
\text { sistemiškai, objektyviai, } \\
\text { analizuojant pagrindinių } \\
\text { tyrimo subjektų dinami- } \\
\text { ką, įvertinant }\end{array}$ \\
\hline
\end{tabular}




\begin{tabular}{|c|c|c|c|c|c|c|}
\hline Kriterijus & 0 baluc & 1 balas & 2 balai & 3 balai & 4 balai & 5 balai \\
\hline & & & $\begin{array}{l}\text { (atmestinai) ir (ar) } \\
\text { nekorektiškai. }\end{array}$ & & $\begin{array}{l}\text { rodiklių analize. Gali- } \\
\text { mos smulkios klaidos, } \\
\text { nepažeidžiančios } \\
\text { darbo nuoseklumo bei } \\
\text { logikos }\end{array}$ & $\begin{array}{l}\text { priežastinius ir pase- } \\
\text { kminius ryšius ir pan.). } \\
\text { Gali būti pateikiamos } \\
\text { papildomos žinios, atlik- } \\
\text { ta aktualios literatūros } \\
\text { apžvalga. }\end{array}$ \\
\hline $\begin{array}{l}\text { Teksto ilius- } \\
\text { travimas }\end{array}$ & $\begin{array}{l}\text { Nèra iliustra- } \\
\text { cinės medžia- } \\
\text { gos (tuose } \\
\text { darbuose, } \\
\text { kuriuose ši } \\
\text { dalis objekty- } \\
\text { viai būtina). }\end{array}$ & $\begin{array}{l}\text { Lentelès, paveikslai } \\
\text { parengti nekorek- } \\
\text { tiškai, nesisieja su } \\
\text { dèstoma (analizuo- } \\
\text { jama) tema; patei- } \\
\text { kiant duomenis yra } \\
\text { stambių skaičiavi- } \\
\text { mo arba jų grafinio } \\
\text { vaizdavimo klaidų. }\end{array}$ & $\begin{array}{l}\text { Didžiojoje darbo } \\
\text { dalyje pasirinkti } \\
\text { netinkami lentelių } \\
\text { ir grafinio duomenų } \\
\text { vaizdavimo modeliai } \\
\text { (pvz., duomenys, } \\
\text { analizuojami logi- } \\
\text { nès analizės būdu, } \\
\text { pateikiami grafikų } \\
\text { pavidalu, raidos ten- } \\
\text { dencijas ar reiškinio } \\
\text { visumą vaizduojantys } \\
\text { duomenys pateikiami } \\
\text { lentelèse ir pan.); } \\
\text { duomenys neiskai- } \\
\text { tomi ir (arba) yra } \\
\text { jų skaičiavimo arba } \\
\text { grafinio vaizdavimo } \\
\text { klaidų. }\end{array}$ & $\begin{array}{l}\text { Vaizdinè medžiaga } \\
\text { pateikta ir apipavida- } \\
\text { linta tinkamai. Galimi } \\
\text { trūkumai: perteklinis } \\
\text { iliustracijụ kiekis } \\
\text { pagrindiniame doku- } \\
\text { mente (dalị iliustra- } \\
\text { cijų rekomenduotina } \\
\text { pateikti prieduose), } \\
\text { yra nedaug neesminių } \\
\text { klaidų apipavidalinant } \\
\text { iliustracinę dali (pvz., } \\
\text { netiksliai suformuluoti } \\
\text { vaizdinès priemonès } \\
\text { pavadinimai, lentelès } \\
\text { duomenys atsikartoja } \\
\text { diagramoje ar pan.). }\end{array}$ & $\begin{array}{l}\text { Vaizdinè medžiaga } \\
\text { sutvarkyta ir pateikta } \\
\text { kokybiškai ir laikan- } \\
\text { tis visų pagrindinių } \\
\text { reikalavimų; gali būti } \\
\text { nedidelè dalis smulkių } \\
\text { netikslumų apipavida- } \\
\text { linant iliustracinę dalị. }\end{array}$ & $\begin{array}{l}\text { Vaizdinė medžiaga } \\
\text { sutvarkyta ir pateikta } \\
\text { kokybiškai, aiškiai } \\
\text { įskaitoma, ją sudarant } \\
\text { ir pateikiant darbe lai- } \\
\text { komasi visų pagrindinių } \\
\text { reikalavimų. }\end{array}$ \\
\hline
\end{tabular}

* Savivaldybių viešujų bibliotekų pateikiamus darbus rekomenduojama priskirti analitinių ataskaitų kategorijai ir ịvertinti juos pagal šiems darbams keliamus reikalavimus. Kai parengtas darbas visiškai atitinka analitinės apžvalgos kriterijus (žr. žanro apibūdinimą 4 priede), tokie darbai îregistruojami šiame duomenų blanke, tačiau pagal analitinių ataskaitų kriterijus nevertinami. 


\section{MOKSLINĖ VEIKLA. JOS REZULTATAI IR JŲ APIBŪDINIMAS}

\begin{tabular}{|c|c|c|c|}
\hline $\begin{array}{l}\text { Eil. } \\
\text { Nr. }\end{array}$ & $\begin{array}{c}\text { Veikla ir (ar) jos rezultato } \\
\text { pavadinimas }\end{array}$ & Veiklos (rezultato) apibūdinimas & Paaiškinimai ir komentarai \\
\hline 1. & $\begin{array}{l}\text { Taikomieji moksliniai } \\
\text { tyrimai }\end{array}$ & $\begin{array}{l}\text { Eksperimentiniai ir (arba) teoriniai pažinimo darbai, atliekami } \\
\text { norint gauti naujų žiniu ir pirmiausia skiriami specifiniams prak- } \\
\text { tiniams tikslams pasiekti arba uždaviniams spręsti. }\end{array}$ & $\begin{array}{l}\text { Parengta mokslinio tyrimo (mokslo tiriamojo } \\
\text { darbo - MTD), sutrumpintai - MTD) ataskai- } \\
\text { ta. Gali būti saugoma rankraščio teisèmis, pu- } \\
\text { blikuojama (ivaairiose laikmenose) ir (arba) šios } \\
\text { ataskaitos pagrindu rengiami mokslo leidiniai } \\
\text { ir (ar) mokslo, metodinès, mokslui populiarinti } \\
\text { skirtos publikacijos. }\end{array}$ \\
\hline \multicolumn{4}{|c|}{ Taikomujų mokslinių tyrimų pagrindu gali būti parengti ir publikuojami šie tyrimų rezultatai: } \\
\hline 2. & $\begin{array}{l}\text { Mokslinio tyrimo atas- } \\
\text { kaita }\end{array}$ & $\begin{array}{l}\text { Mokslinio tyrimo pagrindu parengtas neperiodinis ir netęstinis } \\
\text { leidinys, kuriame sistemingai ir (ar) išsamiai išnagrinèta viena } \\
\text { tema (dalykas), aiškūs ir žymūs naujumo ir kiekvienai mokslo } \\
\text { sričiai arba krypčiai savi moksliškumo elementai. }\end{array}$ & $\begin{array}{l}\text { Mokslinio tyrimo ataskaita turi atitikti šiam } \\
\text { mokslinės publikacijos žanrui keliamus reikala- } \\
\text { vimus ir dažniausiai publikuojama institucinèje } \\
\text { talpykloje. }\end{array}$ \\
\hline 2.1 & $\begin{array}{l}\text { Mokslinio tyrimo rezulta- } \\
\text { tų publikavimas }\end{array}$ & $\begin{array}{l}\text { Mokslinio tyrimo pagrindu parengta monografija, studija, } \\
\text { knygos skyrius, straipsnis, pranešimas moksliniam renginiui } \\
\text { (konferencijai, simpoziumui seminarui ir pan.), atitinkantys } \\
\text { konkrečiam žanrui keliamus reikalavimus. }\end{array}$ & $\begin{array}{l}\text { Mokslinès publikacijos rengiamos ir derinamos } \\
\text { pagal leidinių (taip pat ir elektroniniu), ku- } \\
\text { riuose jos spausdinamos, redakcinių komisijų } \\
\text { reikalavimus. }\end{array}$ \\
\hline 2.1 .2 & Mokslo monografija & $\begin{array}{l}\text { Neperiodinis ir netęstinis leidinys, kuriame sistemingai ir (ar) } \\
\text { išsamiai išnagrinèta viena tema (dalykas), aiškūs ir žymūs nauju- } \\
\text { mo ir kiekvienai mokslo sričiai arba krypčiai savi moksliškumo } \\
\text { elementai. }\end{array}$ & $\begin{array}{l}\text { Monografija privalo turèti ISBN numerį; } \\
\text { mažiausia ịskaitoma apimtis }-8 \text { autoriniai } \\
\text { lankai*. }\end{array}$ \\
\hline 2.1.3. & Mokslo studija & $\begin{array}{l}\text { Mokslo darbas, atitinkantis mokslo straipsniui keliamus reikala- } \\
\text { vimus. }\end{array}$ & $\begin{array}{l}\text { Mažiausia įskaitoma apimtis - } 2 \text { autoriniai } \\
\text { lankai*. }\end{array}$ \\
\hline
\end{tabular}




\begin{tabular}{|c|c|c|c|}
\hline $\begin{array}{l}\text { Eil. } \\
\text { Nr. }\end{array}$ & $\begin{array}{c}\text { Veikla ir (ar) jos rezultato } \\
\text { pavadinimas }\end{array}$ & Veiklos (rezultato) apibūdinimas & Paaiškinimai ir komentarai \\
\hline 2.1.4. & Mokslo straipsnis & $\begin{array}{l}\text { Straipsnis, paskelbtas mokslineje spaudoje (recenzuojamame } \\
\text { leidinyje**) ir atitinkantis toje mokslo kryptyje pripažistamus } \\
\text { moksliškumo kriterijus (paprastai recenzuotas ne mažiau kaip } \\
\text { dvieju turinčiu mokslo laipsnị tos mokslo srities (krypties) ekspertu). }\end{array}$ & $\begin{array}{l}\text { Mokslo leidiniai dažniausiai yra nustatę kon- } \\
\text { krečius šių publikacijų reikalavimus. } \\
\text { Bendriausi formos reikalavimai: } \\
\text { turi konkrečioje mokslo srityje iprastą mokslinį } \\
\text { aparatą (metodologijos aprašą, išnašas, biblio- } \\
\text { grafiją ir (ar) formules, statistines lenteles, grafi- } \\
\text { kus (iliustracijas) ir pan.). } \\
\text { Mažiausia ịskaitoma apimtis humanitarinių } \\
\text { ir socialinių mokslų srityse - } 0,25 \text { autorinio } \\
\text { lanko*. }\end{array}$ \\
\hline 2.1 .5 . & $\begin{array}{l}\text { Straipsnis mokslinès (arba } \\
\text { mokslinès praktinès) kon- } \\
\text { ferencijos sesijoje, semi- } \\
\text { nare, simpoziume ir (ar) } \\
\text { kitame mokslo renginyje }\end{array}$ & $\begin{array}{l}\text { Mokslinio tyrimo rezultatų pristatymas. } \\
\text { Straipsnio apimtis ir struktūra priklauso nuo straipsnio tipo } \\
\text { (probleminis, naujo sprendimo pristatymas, stendinis straipsnis, } \\
\text { trumpas straipsnis ir pan.), kas organizuoja mokslinį renginį, } \\
\text { tokių renginių organizavimo tradicijų. }\end{array}$ & $\begin{array}{l}\text { Geriausia naudotis šablono principu: rekomen- } \\
\text { duojama gauti ir išanalizuoti analogiškų rengi- } \\
\text { nių medžiagoje paskelbtus straipsnius ar tokiu } \\
\text { renginių kvietimo puslapyje patalpintą šabloną. }\end{array}$ \\
\hline 2.1.6. & $\begin{array}{l}\text { Mokymo ir metodinè } \\
\text { priemoné }\end{array}$ & $\begin{array}{l}\text { Nustatyta tvarka iteisinta ir publikuota vadovelio ar mo- } \\
\text { komosios knygos kategorijoms nepriskirta mokymo ir (ar) } \\
\text { metodine priemone (pratybų metodiniai nurodymai, paskaitų } \\
\text { konspektai, metodinès rekomendacijos, metodinis laiškas, pa- } \\
\text { teikčių rinkiniai ir pan.). }\end{array}$ & \\
\hline 2.1.7. & $\begin{array}{l}\text { Straipsnis kultūros ir pro- } \\
\text { fesiniuose leidiniuose }\end{array}$ & $\begin{array}{l}\text { Mokslinio tyrimo pagrindu parengta publikacija su moksliniu } \\
\text { aparatu mokslo, kultūros ir profesiniuose }{ }^{* * *} \text { tęstiniuose ir vien- } \\
\text { kartiniuose leidiniuose. }\end{array}$ & $\begin{array}{l}\text { Turi konkrečioje mokslo srityje ịprastą mokslinị } \\
\text { aparatą (metodologijos aprašą, išnašas, bibli- } \\
\text { ografiją, ir (ar) formules, statistines lenteles, } \\
\text { grafikus (iliustracijas) ir pan.). Paprastai šios } \\
\text { publikacijos nerecenzuojamos. }\end{array}$ \\
\hline 2.1.8. & $\begin{array}{l}\text { Straipsnis mokslo popu- } \\
\text { liariame leidinyje }\end{array}$ & $\begin{array}{l}\text { Mokslinio tyrimo ar (ir) mokslo medžiagos pagrindu parengtas } \\
\text { straipsnis, kuriame ne specialistui suprantama forma ir stiliumi } \\
\text { aprašomi tyrimo rezultatai. }\end{array}$ & \\
\hline
\end{tabular}




\begin{tabular}{|c|c|c|c|}
\hline $\begin{array}{l}\text { Eil. } \\
\text { Nr. }\end{array}$ & $\begin{array}{c}\text { Veikla ir (ar) jos rezultato } \\
\text { pavadinimas }\end{array}$ & Veiklos (rezultato) apibūdinimas & Paaiškinimai ir komentarai \\
\hline 2.1.9. & $\begin{array}{l}\text { Tyrimo duomenų prista- } \\
\text { tymas viešojoje erdvëje }\end{array}$ & $\begin{array}{l}\text { Mokslinio tyrimo ar (ir) mokslo medžiagos pagrindu pareng- } \\
\text { tas pranešimas, paskaita, kalba ir pan., kuriame ne specialistui } \\
\text { suprantama forma ir stiliumi pateikiami tyrimo rezultatai (skai- } \\
\text { toma vieša paskaita, dalyvaujama televizijos ar radijo laidoje, } \\
\text { viešoje diskusijoje ir pan.). }\end{array}$ & \\
\hline \multicolumn{4}{|c|}{$\begin{array}{l}\text { 3. Kita mokslinè veikla (gali būti ir su konkrečiu moksliniu tyrimu, ir su kitos mokslo medžiagos panaudojimu } \\
\text { ir (ar) pristatymu siejama veikla) }\end{array}$} \\
\hline 3.1. & $\begin{array}{l}\text { Teorinis, sintetinis mokslo } \\
\text { darbas }\end{array}$ & $\begin{array}{l}\text { Kurią nors mokslo krypti, šaką, discipliną apimantis ar tarp- } \\
\text { dalykinio pobūdžio darbas, sintetinantis ilgalaikius tyrimus, } \\
\text { pateiktus monografijose, studijose bei mokslo straipsniuose, } \\
\text { atitinkantis monografijoms keliamus mokslinio lygio ir adresato } \\
\text { reikalavimus. } \\
\text { Kurią nors mokslo krypti, šaka, discipliną apimantis ar tarp- } \\
\text { dalykinio pobūdžio darbas, sintetinantis ilgalaikius tyrimus, } \\
\text { pateiktus monografijose, studijose bei mokslo straipsniuose, } \\
\text { atitinkantis monografijoms keliamus mokslinio lygio ir adresato } \\
\text { reikalavimus paprastai rengiamas kelių autorių ir redaktorių } \\
\text { kolektyvų. }\end{array}$ & \\
\hline 3.2. & $\begin{array}{l}\text { Apžvalginis mokslo } \\
\text { straipsnis }\end{array}$ & $\begin{array}{l}\text { Informatyvus analitiniais vertinimais, palyginimais ir nuoro- } \\
\text { domis, formuluojantis ne tik problemas, bet nurodantis ir ju } \\
\text { sprendimo kelius, sąsajas su gretimais tyrimais, apibrěžiantis } \\
\text { tolimesnių tyrimų gaires, neišspręstas problemas. }\end{array}$ & $\begin{array}{l}\text { Paprastai tokius straipsnius rengia autoritetingi } \\
\text { mokslininkai ir jie spausdinami prestižiniuose } \\
\text { (paprastai recenzuojamuose) leidiniuose. Apim- } \\
\text { ties reikalavimai gali skirtis nuo mokslo straips- } \\
\text { niui keliamų reikalavimų (dažniau leidžiama } \\
\text { didesnè straipsnio apimtis); straipsniui būtinas } \\
\text { iprastas mokslinis aparatas. }\end{array}$ \\
\hline
\end{tabular}




\begin{tabular}{|c|c|c|c|}
\hline $\begin{array}{l}\text { Eil. } \\
\text { Nr. }\end{array}$ & $\begin{array}{c}\text { Veikla ir (ar) jos rezultato } \\
\text { pavadinimas }\end{array}$ & Veiklos (rezultato) apibūdinimas & Paaiškinimai ir komentarai \\
\hline 3.3. & Publikacijos & $\begin{array}{l}\text { Straipsniai, knygų skyriai, akademinés recenzijos, kitos publika- } \\
\text { cijos su moksliniu aparatu mokslo, kultūros ir profesiniuose*** } \\
\text { tęstiniuose ir vienkartiniuose leidiniuose. }\end{array}$ & $\begin{array}{l}\text { Turi konkrečioje mokslo srityje iprastą mokslinị } \\
\text { aparatą (metodologijos aprašą, išnašas, bibli- } \\
\text { ografiją ir (ar) formules, statistines lenteles, } \\
\text { grafikus (iliustracijas) ir pan.). Paprastai šios } \\
\text { publikacijos nerecenzuojamos. }\end{array}$ \\
\hline 3.4. & Knygos skyrius & $\begin{array}{l}\text { Originalaus ar apžvalginio mokslinio straipsnio pobūdị atitin- } \\
\text { kantis mokslo darbas, paskelbtas neperiodiniame leidinyje (išsky- } \\
\text { rus konferencijos darbų leidinius). }\end{array}$ & \\
\hline 3.5. & $\begin{array}{l}\text { Mokslinis žinynas, en- } \\
\text { ciklopedija, (bio)biblio- } \\
\text { grafija }\end{array}$ & $\begin{array}{l}\text { Konkrečios srities ar krypties mokslo veikalas, } \\
\text { skirtas mokslo (ir studiju) reikmems ir atitinkantis tos srities ar } \\
\text { krypties moksliškumo ir sistemingumo reikalavimus; išskyrus } \\
\text { visuomenei šviesti, mokslui populiarinti, administracinems } \\
\text { funkcijoms atlikti skirtus informacinius leidinius. }\end{array}$ & \\
\hline 3.6. & Vadovas & $\begin{array}{l}\text { Informacinis leidinys, kuriame pateikiamos trumpos mokslinio, } \\
\text { gamybinio ar taikomojo pobūdžio žinios, išdėstytos skaitytojams } \\
\text { lengvai suprantama abecèline, sistemine ar chronologine tvarka. }\end{array}$ & \\
\hline 3.7. & $\begin{array}{l}\text { Mokslo populiarus lei- } \\
\text { dinys }\end{array}$ & $\begin{array}{l}\text { Leidinys, kuriame ne specialistui suprantama forma ir stiliumi } \\
\text { aprašomi mokslo, kultūros, technikos dalykai, mokslinių ieškoji- } \\
\text { mų metodai ir kryptys, pateikiamos mokslininkų biografijos. }\end{array}$ & \\
\hline 3.8. & $\begin{array}{l}\text { Straipsnis mokslo popu- } \\
\text { liariame leidinyje }\end{array}$ & $\begin{array}{l}\text { Mokslinio tyrimo ir (ar) mokslo medžiagos pagrindu parengtas } \\
\text { straipsnis, kuriame ne specialistui suprantama forma ir stiliumi } \\
\text { aprašomi mokslo, kultūros ir technikos dalykai. }\end{array}$ & \\
\hline 3.9. & $\begin{array}{l}\text { Sudarytas ir (ar) redaguo- } \\
\text { tas mokslo darbas }\end{array}$ & $\begin{array}{l}\text { Originalių mokslo darbų rinkinys arba kolektyvinis mokslo dar- } \\
\text { bas; priskiriamas sudarytojui (redaktoriui), nurodytam leidinio } \\
\text { antraštiniame puslapyje ir (ar) metrikoje, išskyrus periodinio } \\
\text { arba tęstinio mokslo leidinio nuolatinio redaktoriaus darbą. }\end{array}$ & \\
\hline
\end{tabular}




\begin{tabular}{|c|c|c|c|}
\hline $\begin{array}{l}\text { Eil. } \\
\text { Nr. }\end{array}$ & $\begin{array}{l}\text { Veikla ir (ar) jos rezultato } \\
\text { pavadinimas }\end{array}$ & Veiklos (rezultato) apibūdinimas & Paaiškinimai ir komentarai \\
\hline 3.10 . & Vertimai & $\begin{array}{l}\text { Mokslinio teksto - monografiju, studijų, originalių teorinių } \\
\text { mokslo darbų, mokslo šaltinių publikacijų, taikomujų mokslo } \\
\text { darbu, sudarytu mokslo darbu, mokslo recenzijų, mokslo straips- } \\
\text { nių vertimas iš vienos kalbos ị kitą. }\end{array}$ & \\
\hline 3.11 . & $\begin{array}{l}\text { Moksliškai komentuotas } \\
\text { vertimas }\end{array}$ & $\begin{array}{l}\text { Mokslo srities ar krypties raidai aktualaus arba istoriškai reikš- } \\
\text { mingo veikalo vertimas iš lietuvių kalbos arba ị lietuvių kalbą; } \\
\text { moksliniu komentavimu laikomi palydimieji tekstai, pristatantys } \\
\text { veikalą bei jo pateikimo ypatumus straipsnių ir (ar) komentaru, } \\
\text { ir (ar) žodynellių, ir (ar) sąvokų rodyklių forma; mokslinio apa- } \\
\text { rato būtinumo kriterijus ekspertų sprendimu netaikomas klasi- } \\
\text { kinio arba filosofinio veikalo vertimui, kuris pasižymi sistemišku } \\
\text { intelektualiosios kalbos kūrimu. }\end{array}$ & \\
\hline 3.12 . & Recenzija & $\begin{array}{l}\text { Vertinamasis pranešimas naują literatūrinị ar mokslinį veikalą, } \\
\text { dažniausiai parašytą ir pasirašytą kvalifikuoto asmens, spausdina- } \\
\text { mas laikraštyje, žurnale arba periodiniame leidinyje. Jis gali būti } \\
\text { aprašomojo, ataskaitinio, lyginamojo arba kritinio pobūdžio; } \\
\text { recenzija taip pat gali būti priemonè pateikti ilgesnę esė, kurioje } \\
\text { recenzentas aptaria kelis neseniai publikuotus darbus (recenziju } \\
\text { rinktinė) arba platesnę temą, kuriai recenzuoti darbai tampa } \\
\text { „pradiniu tašku“. } \\
\text { Sinonimas - kritika. } \\
\text { Lyginti su reklama (perdètu gyrimu). }\end{array}$ & $\begin{array}{l}\text { Gali būti spausdinama recenzuojamuose, moks- } \\
\text { lo, meno, kultūros leidiniuose, taip pat mokslo } \\
\text { populiarinimo, profesiniuose leidiniuose. }\end{array}$ \\
\hline 3.13. & Akademinè recenzija & $\begin{array}{l}\text { Išsamus ir argumentuotas publikuoto veikalo mokslinis ịverti- } \\
\text { nimas. }\end{array}$ & $\begin{array}{l}\text { Mažiausia ịskaitoma apimtis }-0,25 \text { autorinio } \\
\text { lanko*. }\end{array}$ \\
\hline 3.14 & $\begin{array}{l}\text { Konferencijos darbų lei- } \\
\text { dinys }\end{array}$ & $\begin{array}{l}\text { Vienkartinis leidinys ar serijinio leidinio tomas (jo dalis), ku- } \\
\text { riame spausdinami mokslo konferencijos pranešimų turinị ati- } \\
\text { tinkantys tekstai, nepereję recenzuojamiems leidiniams ịprastos } \\
\text { recenzavimo (peer review) procedūros. }\end{array}$ & $\begin{array}{l}\text { Reikalavimus, keliamus leidiniui ir jame pu- } \\
\text { blikuojamiems darbams, nustato konferencijos } \\
\text { rengèjai ir (arba) jų paskirta ekspertų grupè. }\end{array}$ \\
\hline
\end{tabular}




\begin{tabular}{|c|c|c|c|}
\hline $\begin{array}{l}\text { Eil. } \\
\text { Nr. }\end{array}$ & $\begin{array}{c}\text { Veikla ir (ar) jos rezultato } \\
\text { pavadinimas }\end{array}$ & Veiklos (rezultato) apibūdinimas & Paaiškinimai ir komentarai \\
\hline 3.15 . & $\begin{array}{l}\text { Mokslinès (mokslinès- } \\
\text { praktinès) konferencijos }\end{array}$ & $\begin{array}{l}\text { Naujos savarankiškos konferencijos organizuojamos tada, kai } \\
\text { susiformuoja tam tikra žinių masė konkrečioje srityje ir bendra- } \\
\text { minčiai imasi diskutuoti apie naujas idèjas ir galimas jų raidos } \\
\text { pasekmes. }\end{array}$ & $\begin{array}{l}\text { Mokslo institucijos paprastai yra patvirtinusios } \\
\text { mokslinės konferencijos organizavimo tvarkos } \\
\text { aprašus, kuriuose nustatoma konferencijų, } \\
\text { prašymu joms organizuoti pateikimo, organiza- } \\
\text { vimo, konferencijos dalyvio pažymejimo (serti- } \\
\text { fikato) parengimo, išdavimo tvarka. }\end{array}$ \\
\hline 3.16. & $\begin{array}{l}\text { Konferencijų pranešimų } \\
\text { tezės }\end{array}$ & $\begin{array}{l}\text { Mokslinès tezès: glaustai išdèstyti pagrindiniai mokslinio pra- } \\
\text { nešimo teiginiai, atskleidžiantys tyrimų reikalingumą, esmę ir jų } \\
\text { reikšmę mokslo šakos plètrai. }\end{array}$ & \\
\hline 3.17. & $\begin{array}{l}\text { Taikomoji mokslinė } \\
\text { veikla (kitaip - socialinė, } \\
\text { kultūrinè plètra) }\end{array}$ & 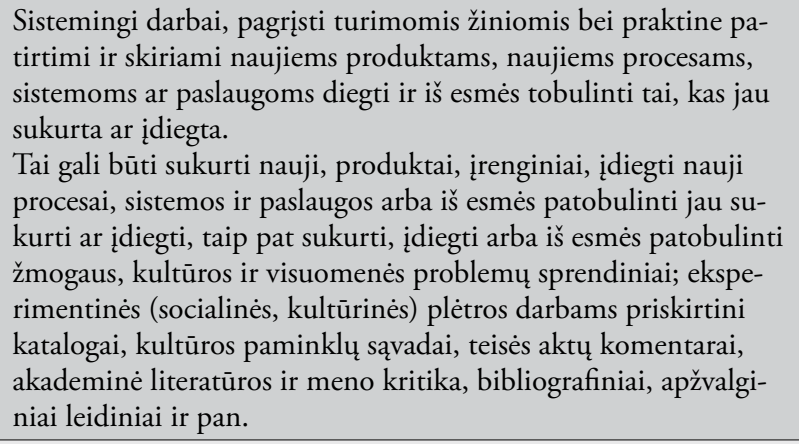 & $\begin{array}{l}\text { Socialinės kultūrinès plètros darbu vienetu } \\
\text { visais atvejais laikomas tik rinkinys (ciklas, } \\
\text { komplektas, kuri sudaro ne mažiau kaip } 4 \text { vie- } \\
\text { netai) arba leidinys, kurị sudaro ne mažiau nei } \\
2 \text { autoriniai lankai, o ne atskiras mažos apimties } \\
\text { tekstas, aprašas, paskaita, laida, fragmentas ir kt. }\end{array}$ \\
\hline 3.18. & Šaltinio publikacija & $\begin{array}{l}\text { Mokslinę vertę turinčių archyvinių dokumentu, kalbos pamin- } \\
\text { klų, jų rinkinių ir kitų tekstinių bei audiovizualinių šaltinių } \\
\text { atrinkimas ir parengimas publikavimui parūpinant mokslinį } \\
\text { aparatą (transkripcijas, komentarus, rodykles ir kt.). }\end{array}$ & \\
\hline
\end{tabular}




\begin{tabular}{|c|c|c|c|}
\hline $\begin{array}{l}\text { Eil. } \\
\text { Nr. }\end{array}$ & $\begin{array}{c}\text { Veikla ir (ar) jos rezultato } \\
\text { pavadinimas }\end{array}$ & Veiklos (rezultato) apibūdinimas & Paaiškinimai ir komentarai \\
\hline 3.19 . & $\begin{array}{l}\text { Mokslo palikimo publi- } \\
\text { kacijos }\end{array}$ & $\begin{array}{l}\text { Mokslo tiriamojo objekto vertę turinčių archyvinių dokumentų, } \\
\text { kalbos paminklu, filosofinės minties klasikinių tekstų, folkloro } \\
\text { rinkinių ir kitų tekstinių mokslo šaltinių (taip pat audiovizua- } \\
\text { liniu) atrinkimas, sudarymas ir parengimas spaudai, apimantis } \\
\text { šaltinio tekstą ir pagalbinị mokslinį aparatą (transkripcijas, } \\
\text { komentarus ir kt.). İskaitoma prie publikuoto mokslo šaltinio } \\
\text { nurodytam rengèjui (rengëjams). }\end{array}$ & \\
\hline 3.20. & Ekspertinè veikla & $\begin{array}{l}\text { Specializuota informacija, ekspertizés, vertinimai ir komentarai } \\
\text { (istoriniai, filologiniai, menotyriniai, sociologiniai, teisès aktų ir } \\
\text { jų projektu), pateikti valstybès bei savivaldybių institucijoms. }\end{array}$ & \\
\hline 3.21. & Edukacinė veikla & $\begin{array}{l}\text { Didelès kultūrinės ir (ar) visuomeninės vertės autorinės, moksliš- } \\
\text { kai pagrįstos, tačiau neprofesionalų auditorijai skirtos parengtos } \\
\text { ir vestos TV, radijo laidos, publikacijos spausdintinėse arba elek- } \\
\text { troninėse žiniasklaidos priemonėse, viešos paskaitos visuomenei } \\
\text { su diskusijomis, dokumentinių filmų scenarijai ir pan. }\end{array}$ & \\
\hline 3.22. & $\begin{array}{l}\text { Dalyvavimas tarptautinèse } \\
\text { mokslinėse konferencijo- } \\
\text { se, projektuose, moksliné- } \\
\text { se stažuotèse }\end{array}$ & $\begin{array}{l}\text { Dalyvio, pranešèjo teisėmis; projektuose - projektu vadovo, } \\
\text { partnerio ar kt. teisèmis. }\end{array}$ & \\
\hline 3.23. & Analitinė apžvalga & $\begin{array}{l}\text { Dokumentas, kuriame pateikiamas sutrumpintas, susistemintas } \\
\text { ir apibendrintas pirminių dokumentų turinys, pagrindiniai } \\
\text { duomenys, reikalingi suformuluotiems teiginiams pagrịsti, bei } \\
\text { apibendrintos išvados. }\end{array}$ & $\begin{array}{l}\text { Apžvalgos gali būti rengiamos įvairių publikaciju, } \\
\text { taip pat valdymo dokumentu (pvz., struktūrinių } \\
\text { padalinių, taip pat institucijos ar jos struktūrinių } \\
\text { padalinių darbuotojų veiklos ataskaitu) pagrindu; } \\
\text { pagrindinis reikalavimas, keliamas šiam dokumen- } \\
\text { tui, - pateikiama glausta ir susisteminta informa- } \\
\text { cija, tekstas formuluojamas pradedant esminiu } \\
\text { teiginiu, veliau išdėstant svarbiausius argumentus } \\
\text { (arba komentarus) šiam teiginiui pagrįsti. }\end{array}$ \\
\hline
\end{tabular}




\begin{tabular}{|c|c|c|c|}
\hline $\begin{array}{l}\text { Eil. } \\
\text { Nr. }\end{array}$ & $\begin{array}{c}\text { Veikla ir (ar) jos rezultato } \\
\text { pavadinimas }\end{array}$ & Veiklos (rezultato) apibūdinimas & Paaiškinimai ir komentarai \\
\hline 3.24. & Analitinė ataskaita & $\begin{array}{l}\text { Dokumentas, kuriame pateikiamas detalus studijuojamo objek- } \\
\text { to ar nagrinëjamo klausimo tyrimas; argumentuojamas darbo } \\
\text { aktualumas, nusakomais jo tikslas ir pagrindiniai uždaviniai, } \\
\text { apibüdinami šaltiniai, kuriais remiantis tyrinèjamas klausimas, } \\
\text { ar objektas. Analizuojamos svarbiausios temos. Logiškai, tiksliai } \\
\text { ir nuosekliai dėstoma medžiaga, pateikiamos ne tik argumentuo- } \\
\text { tos išvados, bet ir gautų rezultatų produktyvumo (bendriausia } \\
\text { prasme - išteklių panaudojimo rodiklis, santykis tarp rezultatų ir } \\
\text { sąnaudu; paslaugų sektoriuje matuojama sudètingiau ir remiantis } \\
\text { kitokiais kriterijais) įvertinimas bei tolesnès raidos prognozė. }\end{array}$ & $\begin{array}{l}\text { Svarbiausias analitinès ataskaitos elementas - } \\
\text { analizės metodas; gali būti naudojamas lygina- } \\
\text { masis, kritinis, sisteminis, koreliacinis ir kt. } \\
\text { Dažniausias veiklos analizés pagrindas - vei- } \\
\text { klos rezultatų ir siekiamų (planiniu) tikslų } \\
\text { palyginimas; pritaikoma savotiška stebèsenos } \\
\text { sistema, visų analizuojamų subjektų dinamikos } \\
\text { vertinimai. }\end{array}$ \\
\hline
\end{tabular}




\section{MOKSLO TIRIAMIEJI DARBAI IR ŠIŲ DARBŲ SKLAIDAI SKIRTOS PUBLIKACIJOS, PARENGTOS SAVIVALDYBIŲ VIEŠOSIOSE BIBLIOTEKOSE 2010-2015 METAIS}

Gerbiamieji biblioteku vadovai,

... apskrities viešoji biblioteka tęsia $2016 \mathrm{~m}$. pradèta tyrima "Savivaldybiu viešuju biblioteku moksline (tiriamoji) veikla 2010-2015 metais“, kuri koordinuoja Lietuvos nacionaline Martyno Mažvydo biblioteka. Šiame tyrimo etape renkame informacija apie bibliotekose 2010-2015 metais atliktus tyrimus, ju pagrindu parengtus biblioteku darbuotoju straipsnius, pranešimus moksliniuose rengininose ir kitus panašaus pobüdžio darbus. Biblioteku tiriamoji veikla ne visada büna pristatyta metinese ataskaitose, todèl mes neturime apie ja išsamios informacijos. Noredami užtikrinti informacijos išsamuma ir patikimuma, kreipiames i Jus, prašydami pateikti duomenis apie Jüsu bibliotekoje atliktus tyrimus 2010-2015 metais bei kita tyrimui reikalinga informaciją. Labai prašome užpildyti šia forma iki šiu metu ... dienos ir atsiusti adresu ... .

Kilus klausimų prašom kreiptis į ..., tel. ..., el. paštas ... .

Dékojame už bendradarbiavima. 


\begin{tabular}{|c|c|c|c|c|}
\hline \multicolumn{5}{|c|}{ 1. Bibliotekos darbuotojų atlikti tyrimai } \\
\hline \multicolumn{5}{|c|}{ 1.1. Moksliniai tyrimai } \\
\hline \multicolumn{5}{|c|}{ 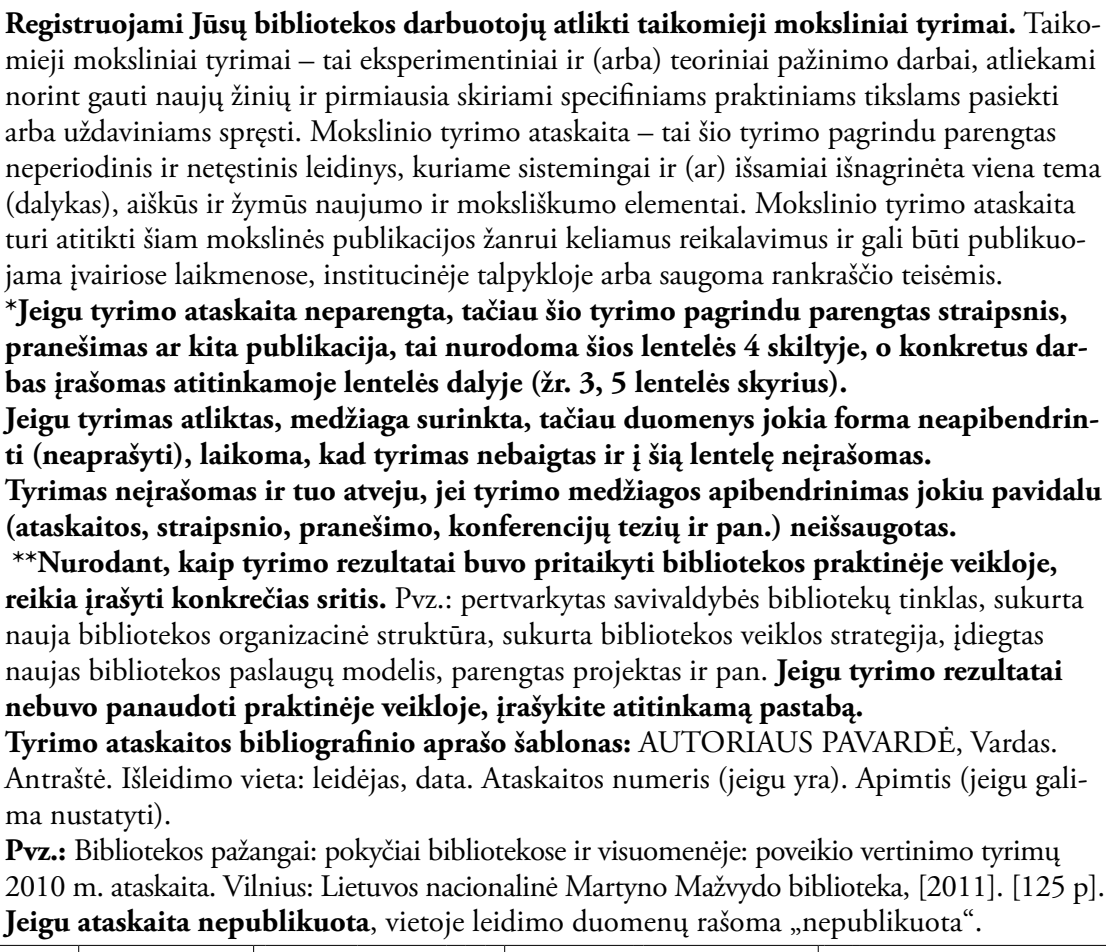 } \\
\hline $\begin{array}{l}\text { Eil. } \\
\text { Nr. }\end{array}$ & $\begin{array}{l}\text { Kelintais } \\
\text { metais at- } \\
\text { liktas tyri- } \\
\quad \text { mas }\end{array}$ & $\begin{array}{l}\text { Tyrimo ataskaitos } \\
\text { bibliografinis } \\
\text { aprašas }\end{array}$ & $\begin{array}{c}\text { Tyrimo ataskaitos } \\
\text { saugojimo vieta* } \\
\text { (nurodomas konkretus } \\
\text { struktūrinis padalinys, } \\
\text { bibliotekos archyvas, } \\
\text { bibliotekos svetainè ir } \\
\text { pan.) }\end{array}$ & $\begin{array}{c}\text { Tyrimo rezultatai } \\
\text { pritaikyti bibliotekos } \\
\text { praktinèje veikloje** } \\
\text { (nurodoma konkreti } \\
\text { sritis) }\end{array}$ \\
\hline 1 & 2 & 3 & 4 & 5 \\
\hline \multicolumn{5}{|l|}{1.} \\
\hline \multicolumn{5}{|l|}{2.} \\
\hline \multicolumn{5}{|l|}{$3 \ldots$} \\
\hline \multicolumn{5}{|c|}{ 1.1. Rinkos tyrimams priskiriami darbai } \\
\hline \multicolumn{5}{|c|}{$\begin{array}{l}\text { Tai Jūsų bibliotekos darbuotojų atlikti bibliotekos veiklos aplinkos tyrimai, poreikių } \\
\text { analizès ir prognozès, viešosios nuomonès ir kiti tyrimai, kurių rezultatai gali būti } \\
\text { panaudojami modeliuojant paslaugas ir priimant strateginius sprendimus. Pvz.: gyven- } \\
\text { tojų arba bibliotekos vartotojų apklausos, siekiant išsiaiškinti, kaip jie vertina bibliotekos }\end{array}$} \\
\hline
\end{tabular}


teikiamas paslaugas, ar juos tenkina paslaugų kokybè, kokios potencialios vartotojų grupès nesinaudoja bibliotekos paslaugomis ir kokias paslaugas reikètų sukurti, kad ši grupè pradètų lankytis bibliotekoje, kokios bibliotekos naudojamos reklamos priemonès yra veiksmingiausios, bibliotekos įvaizdžio tyrimai ir t. t.

* Jeigu tyrimas atliktas, medžiaga surinkta, tačiau duomenys jokia forma neapibendrinti (neaprašyti), laikoma, kad tyrimas nebaigtas ir ị šią lentelę neįrašomas. Tyrimas neịrašomas ir tuo atveju, jei tyrimo medžiagos apibendrinimas jokiu pavidalu (ataskaitos, straipsnio, pranešimo, konferencijų tezių ir pan.) neišsaugotas.

** Jeigu pateikiamas tyrimo ataskaitos (apžvalgos, apibendrinimo) bibliografinis aprašas, temos nurodyti nereikia.

*** Jeigu tyrimo ataskaita neparengta, tačiau šio tyrimo pagrindu yra parengtas straipsnis, pranešimas ar kita publikacija, tai nurodoma šios lentelès 5 skiltyje, o konkretus darbas įrašomas atitinkamoje lentelès dalyje (žr. 3, 5 lentelès skyrius).

****Nurodant, kaip tyrimo rezultatai buvo pritaikyti bibliotekos praktinëje veikloje, reikia ịrašyti konkrečias sritis. Pvz.: parengtas projektas, įdiegtos naujos technologijos, patobulintos arba sukurtos naujos paslaugos, sukurtos naujos bibliotekos reklamos priemonès ir pan. Jeigu tyrimo rezultatai nebuvo panaudoti praktinèje veikloje, ịrašykite atitinkamą pastabą.

\begin{tabular}{|c|c|c|c|c|c|}
\hline $\begin{array}{l}\text { Eil. } \\
\text { Nr. }\end{array}$ & $\begin{array}{c}\text { Kelintais } \\
\text { metais at- } \\
\text { liktas tyri- } \\
\text { mas }\end{array}$ & $\begin{array}{l}\text { Tyrimo atas- } \\
\text { kaitos (apž- } \\
\text { valgos, api- } \\
\text { bendrinimo) } \\
\text { bibliografinis } \\
\text { aprašas* }\end{array}$ & $\begin{array}{l}\text { Tyrimo } \\
\text { tema** }^{* *}\end{array}$ & $\begin{array}{c}\text { Tyrimo } \\
\text { ataskaitos, } \\
\text { apibendri- } \\
\text { nimo ir pan. } \\
\text { saugojimo } \\
\text { vieta }^{* * *}\end{array}$ & $\begin{array}{l}\text { Tyrimo rezultatai } \\
\text { pritaikyti bibliotekos } \\
\text { praktinèje veiklo- } \\
\text { je } \text { e }^{* * * *} \text { (nurodoma } \\
\text { konkreti sritis) }\end{array}$ \\
\hline 1 & 2 & 3 & 4 & 5 & 6 \\
\hline 1. & & & & & \\
\hline 2. & & & & & \\
\hline 3. ... & & & & & \\
\hline \multicolumn{6}{|c|}{ 1.2. Tyrimai, skirti vadybiniams sprendimams pagrịsti } \\
\hline
\end{tabular}

Tai tyrimai, atlikti Jūsų bibliotekos (dažniausiai vadovu) iniciatyva, kurių tikslas - išanalizuoti bendrą bibliotekos ar atskiros jos veiklos srities situaciją, įvertinti galimybes, sąlygas tolesnei veiklai ar būsimiems rezultatams planuoti. Pvz., periodinių leidinių skaitymo analizè, siekiant pagrịsti lěšų poreikị periodinių leidinių prenumeratai; tam tikros bibliotekos dokumentų fondo dalies panaudojimo analizè, reikalinga nustatant komplektavimo prioritetus, ir pan.

* Jeigu tyrimas atliktas, medžiaga surinkta, tačiau duomenys jokia forma neapibendrinti (neaprašyti), laikoma, kad tyrimas nebaigtas ir ị šią lentelę neįrašomas. Tyrimas neįrašomas ir tuo atveju, jei tyrimo medžiagos apibendrinimas jokiu pavidalu (ataskaitos, straipsnio, pranešimo, konferencijų tezių ir pan.) neišsaugotas.

**Jeigu pateikiamas tyrimo ataskaitos (apžvalgos, apibendrinimo) bibliografinis aprašas, temos nurodyti nereikia.

*** Jeigu tyrimo ataskaita neparengta, tačiau šio tyrimo pagrindu parengtas straipsnis, pranešimas ar kita publikacija, tai nurodoma šios lentelès 5 skiltyje, o konkretus darbas ịrašomas atitinkamoje lentelès dalyje (žr. 3, 5 lentelès skyrius).

****Nurodant, kaip tyrimo rezultatai buvo pritaikyti bibliotekos praktinëje veikloje, reikia ịrašyti konkrečias sritis. Pvz.: parengtas projektas, ịkurtas naujas struktūrinis padalinys, pertvarkytas bibliotekos abonemento fondas, nustatytas kitoks bibliotekos darbo laikas ir pan. 


\begin{tabular}{|c|c|c|c|c|c|c|}
\hline $\begin{array}{l}\text { Eil. } \\
\text { Nr. }\end{array}$ & $\begin{array}{l}\text { Kelintais } \\
\text { metais at- } \\
\text { liktas tyri- } \\
\text { mas }\end{array}$ & \multicolumn{2}{|c|}{$\begin{array}{c}\text { Tyrimo } \\
\text { ataskaitos } \\
\text { bibliografinis } \\
\text { aprašas* }\end{array}$} & $\begin{array}{l}\text { Tyrimo } \\
\text { tema** }\end{array}$ & $\begin{array}{l}\text { Tyrimo atas- } \\
\text { kaitos, api- } \\
\text { bendrinimo ir } \\
\text { pan. saugoji- } \\
\text { mo vieta*** }\end{array}$ & \begin{tabular}{c|c} 
Tyrimo rezul- \\
tatai pritaikyti \\
bibliotekos prak- \\
tinèje veikloje**** \\
(nurodoma konkreti \\
sritis)
\end{tabular} \\
\hline 1 & 2 & \multicolumn{2}{|c|}{3} & 4 & 5 & 6 \\
\hline \multicolumn{7}{|l|}{1.} \\
\hline \multicolumn{7}{|l|}{2.} \\
\hline \multicolumn{7}{|l|}{ 3. ... } \\
\hline \multicolumn{7}{|c|}{ 2. Kiti tyrimai } \\
\hline \multicolumn{7}{|c|}{ 2.1. Bibliotekos bazèje atlikti užsakomieji tyrimai } \\
\hline \multicolumn{7}{|c|}{$\begin{array}{l}\text { Tai Jūsų bibliotekos užsakyti tyrimai, kuriuos atliko kitų organizacijų darbuotojai; pa- } \\
\text { rengtos ir Jūsų bibliotekai pateiktos užsakomųjų tyrimų ataskaitos. }\end{array}$} \\
\hline $\begin{array}{l}\text { Eil. } \\
\text { Nr. }\end{array}$ & $\begin{array}{l}\text { Kelintais } \\
\text { metais at- } \\
\text { liktas tyri- } \\
\text { mas }\end{array}$ & \multicolumn{2}{|c|}{$\begin{array}{l}\text { Tyrimo ataskai- } \\
\text { tos bibliografi- } \\
\text { nis aprašas }\end{array}$} & \multicolumn{2}{|c|}{$\begin{array}{l}\text { Tyrimo ataskaitos sau- } \\
\text { gojimo vieta }\end{array}$} & $\begin{array}{c}\text { Tyrimo rezultatai } \\
\text { pritaikyti bibliotekos } \\
\text { praktinëje veikloje } \\
\text { (nurodoma konkreti } \\
\text { sritis) }\end{array}$ \\
\hline 1 & 2 & \multicolumn{2}{|r|}{3} & \multicolumn{2}{|c|}{4} & 5 \\
\hline \multicolumn{7}{|l|}{1.} \\
\hline \multicolumn{7}{|l|}{2.} \\
\hline \multicolumn{7}{|l|}{$3 . \ldots$} \\
\hline \multicolumn{7}{|c|}{ 2.2. Tyrimai, atlikti mokymosi (studiju) tikslais } \\
\hline \multicolumn{7}{|c|}{$\begin{array}{l}\text { Tai Jūsų bibliotekos veiklos tyrimai, kuriuos atliko studentai. Šių tyrimu pagrindu pa- } \\
\text { rašyti darbai bakalauro, magistro ar daktaro kvalifikaciniam laipsniui igyti. } \\
\text { Čia taip pat ịrašomi tyrimai, kuriuos atliko Jūsų bibliotekos darbuotojai, jeigu tie tyrimai } \\
\text { buvo reikalingi jų studijų reikmėms, rašant bakalauro ar magistro darbą, atliekant kokią } \\
\text { nors kitą su jų mokymusi susijusią užduoti. } \\
\text { *Jeigu tyrimo pagrindu parengtas darbas bibliotekoje nesaugomas, 5-oje skiltyje ịrašy- } \\
\text { kite atitinkamą pastabą. }\end{array}$} \\
\hline $\begin{array}{l}\text { Eil. } \\
\text { Nr. }\end{array}$ & $\begin{array}{l}\text { Kelintais } \\
\text { metais atlik- } \\
\text { tas tyrimas }\end{array}$ & $\begin{array}{l}\text { Ty- } \\
\text { rimo } \\
\text { tema }\end{array}$ & $\begin{array}{l}\text { Kokiu t } \\
\text { tas tyrir } \\
\text { (pvz., b. } \\
\text { darbas, } \\
\text { darbas, } \\
\text { darbas i }\end{array}$ & $\begin{array}{l}\text { kslu atlik- } \\
\text { as } \\
\text { calauro } \\
\text { lagistro } \\
\text { oktoranto } \\
\text { pan.) }\end{array}$ & $\begin{array}{l}\text { Parengto } \\
\text { darbo (dar- } \\
\text { bo kopijos) } \\
\text { saugojimo } \\
\text { vieta* }\end{array}$ & $\begin{array}{l}\text { Tyrimo rezultatai } \\
\text { pritaikyti bibliotekos } \\
\text { praktineje veikloje } \\
\text { (nurodoma konkreti } \\
\text { sritis) }\end{array}$ \\
\hline 1 & 2 & 3 & & 4 & 5 & 6 \\
\hline \multicolumn{7}{|l|}{1.} \\
\hline \multicolumn{7}{|l|}{2.} \\
\hline 3.... & & & & & & \\
\hline
\end{tabular}




\subsection{Tyrimai, kuriuose dalyvavo Jūsų biblioteka}

Tai Jūsų bibliotekos veiklos tyrimai, kuriuos atliko kitos institucijos, o Jūsų biblioteka tik teikè duomenis, platino anketas ir pan.

*Jeigu tyrimo pagrindu parengtas darbas bibliotekoje nesaugomas, 5-oje skiltyje ịrašykite atitinkamą pastabą.

Pastaba. LNB ir AVB atliktų tyrimų, kuriuose dalyvavo Jūsų biblioteka, įrašyti nereikia.

\begin{tabular}{|l|c|c|c|c|}
\hline $\begin{array}{c}\text { Eil. } \\
\text { Nr. }\end{array}$ & $\begin{array}{c}\text { Kelintais } \\
\text { metais at- } \\
\text { liktas tyri- } \\
\text { mas }\end{array}$ & $\begin{array}{c}\text { Tyrimo tema } \\
\text { (pavadinimas) }\end{array}$ & $\begin{array}{c}\text { Parengto darbo } \\
\text { Organizacijos, kuri atliko } \\
\text { tyrima, pavadinimas }\end{array}$ & $\begin{array}{c}\text { (tyrimo ataskaitos, } \\
\text { apibendrinimo ir } \\
\text { pan.) kopijos sau- } \\
\text { gojimo vieta* }\end{array}$ \\
\hline 1 & 2 & 3 & 4 & 5 \\
\hline 1. & & & & \\
\hline 2. & & & & \\
\hline $3 . .$. & & & & \\
\hline & & & & \\
\hline 3. & & & \\
\hline
\end{tabular}

3. Bibliotekos darbuotojų straipsniai bibliotekoje atliktų tyrimų pagrindu; bibliotekos darbuotojų straipsniai, populiarinantys mokslinių tyrimų rezultatus

Registruojami Jūsų bibliotekos darbuotojų straipsniai, parengti atliktų tyrimų pagrindu, kurie gali būti publikuoti:

1) atskiruose mokslo (recenzuotuose) leidiniuose (knygoje, straipsnių rinkinyje);

2) recenzuojamuose periodiniuose leidiniuose (recenzuojamų mokslo žurnalų sąrašą rasite http://www.mab.lt/lt/istekliai-internete/mokslo-zurnalai);

3) nacionaliniuose (centriniuose) kultūros ir meno leidiniuose;

4) profesiniuose periodiniuose leidiniuose;

5) regioniniuose, mokslo populiarinimo ar kitos paskirties leidiniuose.

1. Moksliniai straipsniai; registruojami tik bibliotekos darbuotojų parengti straipsniai jose atliktų tyrimų pagrindu. Moksliniams straipsniams privalomi struktūros elementai: antraštè, anotacija, ịvadas, rezultatai, išvados, literatūros sąrašas, pagal mokslinius reikalavimus sutvarkytos nuorodos ị kitus mokslo darbus bei šaltinius, išnašos, komentarai ir kita pagalbinè informacija.

2. Publicistiniai ir mokslo populiarinimo straipsniai; registruojami tik bibliotekos darbuotoju parengti straipsniai jose atliktų tyrimų pagrindu, jeigu juose pateikiami pagrindiniai moksliniam straipsniui priskiriami elementai: ịvadas, rezultatai, išvados ir literatūros sąrašas.

3. Kiti jūsų bibliotekos darbuotojų straipsniai, kuriuose pristatomi ar apžvelgiami aktualūs tiek jūsų bibliotekoje, tiek kitose institucijose atlikti publikuoti moksliniai tyrimai.

Pastaba: Registruojami straipsniai, kurie skirti mokslinių tyrimų sklaidai, apibendrinimui, tiesioginiam arba netiesioginiam skatinimui naudotis moksliniais darbais ar jų rezultatais.

Šie straipsniai neprivalo atitikti moksliniam straipsniui keliamų reikalavimų.

\section{Straipsnių aprašo šablonai}

Straipsnis knygoje ar kitame monografiniame leidinyje:

STRAIPSNIO AUTORIAUS PAVARDĖ, Vardas. Straipsnio pavadinimas. Iš: Leidinio AUTORIUS arba REDAKTORIUS. Antraštè. Išleidimo vieta: leidèjas, data, puslapiai. 


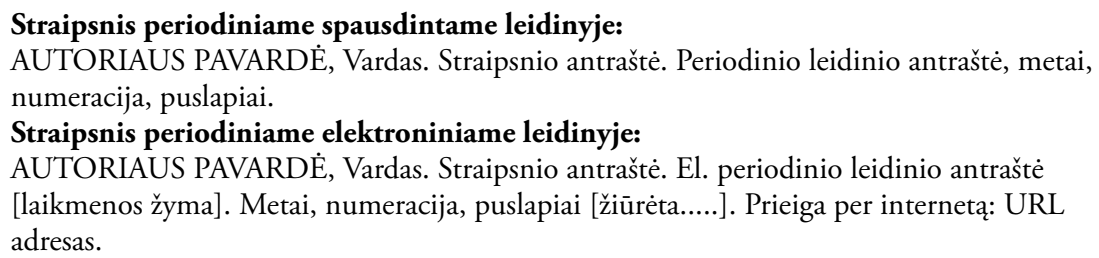

\section{Bibliotekos darbuotojų sudaryti mokslo darbai}

1. Registruojami mokslo darbai, kurių sudarytojai yra Jūsų bibliotekos darbuotojai, o rinkinyje publikuoti darbai yra recenzuoti.

2. Registruojami publicistiniai ar mokslo populiarinimui skirti darbai, kurių sudarytojai yra Jūsų bibliotekos darbuotojai ir kuriuose remiamasi Jūsų bibliotekoje atliktais tyrimais (moksliniais, rinkodaros ar vadybiniams sprendimams priimti).

3. Registruojami Jūsų bibliotekos darbuotojų sudaryti rinkiniai, skirti bibliotekininkystès, bibliografijos ar informacijos mokslo arba šios srities moksliniams darbams populiarinti.

$$
1 .
$$

2.

3. ...

\section{Moksliniai (moksliniai-praktiniai) ir kiti renginiai}

5.1. Bibliotekos darbuotojų pranešimai moksliniam (moksliniam-praktiniam) renginiui

Registruojami Jūsų bibliotekos darbuotojų pranešimai, kurie parengti atliktų tyrimų pagrindu ir (arba) pristatyti moksliniame, moksliniame-praktiniame seminare, mokslinèje, mokslinèje-praktinèje konferencijoje, simpoziume ar kitame tokio statuso renginyje. Jei pranešimas parengtas mokslinio tyrimo pagrindu, būtina nurodyti šio tyrimo pavadinimą (tema).

Pranešimo aprašymo šablonas: AUTORIAUS PAVARDE, Vardas. Pranešimo pavadinimas (tema). Renginio, kuriame skaitytas pranešimas data, rūšis, pavadinimas. Renginio vieta, renginio organizatorius. Rankraštis saugomas: biblioteka, skyrius. Tyrimo, kurio pagrindu parengtas pranešimas, pavadinimas, autorius, data.

Pvz.: KAZILIONYTĖ, Vitalija. Kultūros paveldas Pasvalio rajono bibliotekose: pranešimas, skaitytas $2016 \mathrm{~m}$. kovo $17 \mathrm{~d}$. vykusioje tarptautinëje mokslinèje konferencijoje „Kultūros paveldas ir kultūros vadyba modernioje visuomenëje“. Panevėžys, Panevėžio kraštotyros muziejus. Rankraštis saugomas: Pasvalio r. SVB, Krašto kultūros dokumentavimo centras. Pranešimas parengtas tyrimo „Bibliotekinè kraštotyra Panevė̌̌io apskrities savivaldybių viešosiose bibliotekose" pagrindu, tyrimą atliko Pasvalio r. SVB, 2014.

1.

2.

3. ... 


\subsection{Bibliotekos darbuotojų parengtos tezès moksliniam (moksliniam-praktiniam) renginiui}

\section{Registruojamos Jūsų bibliotekos darbuotojų parengtos tezès moksliniam (moksli- niam-praktiniam) renginiui.}

Aprašo šablonas: AUTORIAUS PAVARDĖ, Vardas. Parengtų tezių (pranešimui) pavadinimas: konferencijos pavadinimas, konferencijos vieta, data.

Išleidimo vieta: leidejas, metai. Puslapių nuoroda.

Pvz.: KAZILIONYTĖ, Vitalija. Kultūros paveldas Pasvalio rajono bibliotekose: pranešimo tezès parengtos tarptautinei mokslinei konferencijai „Kultūros paveldas ir kultūros vadyba modernioje visuomenèje “, vykusioje Panevėžyje, 2016 m. kovo 17 d. Panevėžys: Panevėžio kraštotyros muziejus, 2016. p. 12-14. Tezės parengtos tyrimo „Bibliotekinė kraštotyra Panevėžio apskrities savivaldybių viešosiose bibliotekose" pagrindu, tyrimą atliko Pasvalio rajono SVB, 2014.

$$
\begin{array}{|l}
\hline 1 . \\
\hline 2 . \\
\hline 3 . \ldots \\
\hline
\end{array}
$$

\subsection{Mokslinių (mokslinių-praktinių) renginių organizavimas}

Registruojami Jūsų bibliotekos organizuoti moksliniai (moksliniai-praktiniai) renginiai.

Aprašo šablonas: ORGANIZACIJA. Organizacijos padalinys. Konferencijos statusas ir pavadinimas. Konferencijos data, vieta.

Pvz.: MOLĖTŲ RAJONO SAVIVALDYBĖS VIEŠOJI BIBLIOTEKA ir UTENOS KOLEGIJOS Strateginès plètros skyrius. Mokslinè praktinė konferencija „Viešosios bibliotekos ir kryptinga suaugusiujų neformalaus mokymosi plètra“. $2015 \mathrm{~m}$. vasario 26 d., Molètai.

1.

2.

3. ...

\subsection{Mokslinių tyrimų pristatymas bibliotekos renginiuose}

Registruojami Jūsų bibliotekos organizuoti renginiai (seminarai, seminarai-praktikumai, stažuotès ir pan.), kuriuose buvo pristatomi, aptariami bibliotekose atliktų ar su bibliotekų veikla susijusių mokslinių tyrimų rezultatai ar jų panaudojimo bibliotekų veiklos praktikoje galimybès.

Aprašo šablonas: ORGANIZACIJA. Renginio statusas ir pavadinimas. Renginio data, vieta. Renginyje pristatyta tema, pristate (pranešèjas, lektorius).

Pvz.: VILNIAUS RAJONO SAVIVALDYBÉS CENTRINÉ BIBLIOTEKA. Seminaras rajono SVB darbuotojams. 2012, spalio 10 d., Rudamina. Skaitymo įtaka paauglio asmenybei: mokslinių tyrimų, atliktų Panevéžio miesto SVB 2010-2011 metais, rezultatų pristatymas. Pristate - Panevěžio miesto SVB Vaikų literatūros skyriaus vedejja A. Bratkauskienė. 


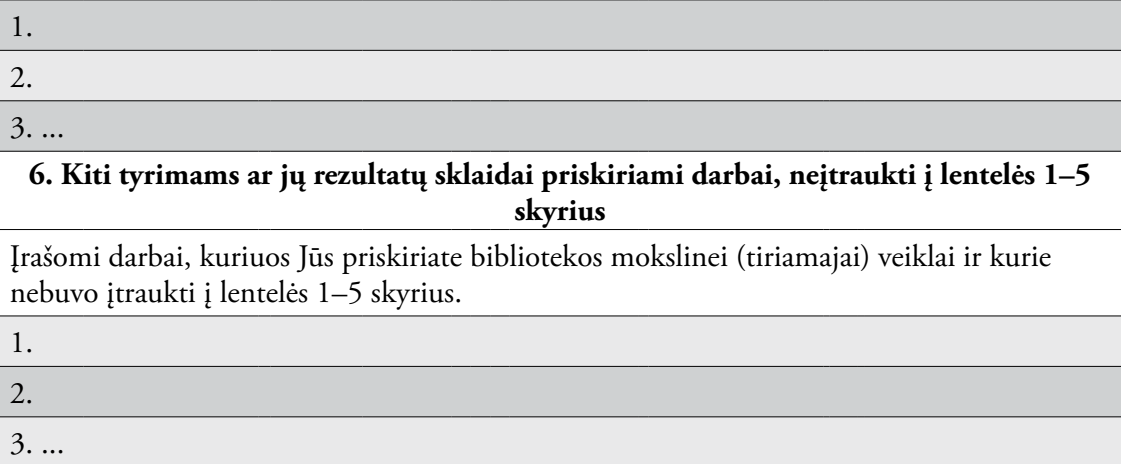




\section{MOKSLO TIRIAMOJI VEIKLA SAVIVALDYBIŲ VIEŠOSIOSE BIBLIOTEKOSE}

\section{Anketa bibliotekų vadovams}

Gerbiami kolegos,

Lietuvos apskričiu viešosios bibliotekos, bendradarbiaudamos su Lietuvos nacionaline biblioteka, atlieka tyrimą „Savivaldybių viešųjų biblioteku mokslo (tiriamoji) veikla 2010-2015 metais“. Šio tyrimo tikslas išsiaiškinti, kokiu būdu savivaldybių viešosios bibliotekos dalyvauja (ar galètų dalyvauti) kuriant ir panaudojant bibliotekininkystès ir informacijos mokslo žinias. Tyrimo rezultatai padès sužinoti, kaip šios žinios galètų būti efektyviau panaudojamos viešųų bibliotekų sektoriuje, aiškiau apibrèžti pačių SVB vaidmeni jas kuriant, išsiaiškinti su tiriamosios veiklos* organizavimu savivaldybių viešosiose bibliotekose susijusias problemas.

I anketos klausimus prašome atsakyti savivaldybių viešųų bibliotekų direktorius. Visuose duomenų rinkimo, jų apdorojimo ir suvestinès informacijos rengimo bei skelbimo etapuose bus užtikrintas gautu duomenu konfidencialumas, šalinama bet kokia informacija, kurios pagrindu duomenis pateikęs asmuo galètų būti tiesiogiai ar netiesiogiai identifikuotas.

\section{Būsime nuoširdžiai dèkingi, jei ịdèmiai ịsiskaitysite ir atvirai atsakysite į pateiktus klausimus.}

* Tiriamoji veikla čia suprantama kaip sistemingai atliekamas kürybinis pažinimo darbas, apimantis bibliotekose atliekamus mokslinius tyrimus, rinkos tyrimus ir (arba) tyrimus, reikalingus vadybiniams sprendimams parengti, ̨̇vairovę analitiniu darbu, kuriais siekiama spręsti praktinius uždavinius (metines bibliotekos veiklos ataskaitas, bibliotekos veiklos ar atskiru jos veiklos sričiu analize ir prognozes, galimybiu vertinimus ir t. t.), taip pat veiklas, skleidžiant informacija apie tiriamuju darbu rezultatus bei integruojant šiuos rezultatus $i$ biblioteku praktiką. 


\section{Ar, Jūsų nuomone, tiriamoji veikla yra svarbi bibliotekų sektoriaus vystymui?}

Pasirinkite viena Jüsų nuomonę atitinkantį atsakymo variantą.
$\square \quad$ Tikrai taip
$\square$ Labiau taip nei ne
$\square \quad$ Labiau ne nei taip
$\square$ Tikrai ne
$\square \quad$ Negaliu pasakyti

\section{2. İvertinkite toliau pateiktus teiginius pagal 5 balų skalę.}

Prie kiekvieno teiginio pažymèkite skaičiu, kurio reikšmè atitinka Jüsu nuomonę. Skaičiu reikšmes: 1 - visiškai nepritariu; 2 - labiau nepritariu, nei pritariu; 3 - nei pritariu, nei nepritariu; 4 - labiau pritariu, nei nepritariu; 5 -visiškai pritariu; 6 - neturiu nuomonés.

\section{Neturiu nuomonès}

1. Tiriamoji veikla plečia žinojimo ribas bibliotekininkystès ir informacijos teorijos ir praktinès veiklos srityse.

2. Tiriamoji veikla padeda išsiaiškinti ir interpretuoti bibliotekoms svarbius visuomeninius reiškinius ir ju esmes.

3. Tiriamoji veikla padeda bibliotekai išlikti konkurencingai.

4. Tiriamoji veikla leidžia numatyti bibliotekos vystymo strategiją.

5. Tiriamoji veikla padeda nustatyti bibliotekos veiklos problemas ir rasti jų sprendimus.

6. Tiriamoji veikla palaiko ir stiprina biblioteku darbuotoju profesines kompetencijas.

7. Reikia papildomu pastangu suprasti moksliniu tyrimų tekstus, o tai labai apsunkina ir tyrimų rezultatų panaudojimą.

8. Svarbiausios biblioteku problemos netyrinëjamos, todèl tyrimų rezultatai ir nèra panaudojami biblioteku praktikoje.

9. Tiriamosios veiklos rezultatai nepanaudojami modeliuojant biblioteku ateitị.

10. Tiriamosios veiklos rezultatai nepanaudojami sprendžiant bibliotekų veiklos problemas. 
11. Bibliotekoms iškylančios problemos efektyviau sprendžiamos remiantis ne tyrimais ir analize, o praktine patirtimi.

12. Tiriamoji veikla yra nereikalingas užsièmimas, atitraukiantis darbuotojus nuo svarbesnių reikalų.

\section{Kaip Jūs ịvertintumète bendrą tiriamosios veiklos būklę viešujuç bibliotekų sektoriuje?}

Pažymèkite viena Jūsų nuomonę labiausiai atitinkantị variantą.

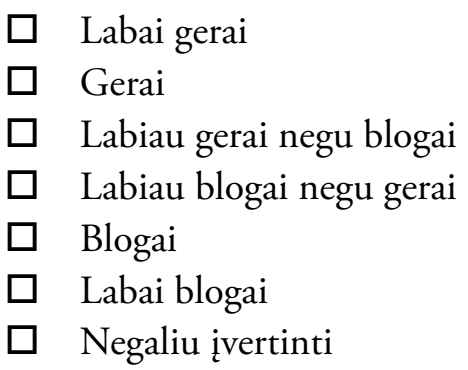

\section{Jei Jums būtų pavesta nustatyti tiriamosios veiklos prioritetus viešujų bibliotekų sektoriuje, kurių bibliotekos veiklos sričiu tyrinè- jimus siūlytumète organizuoti ir vykdyti pirmiausia?}

Ties kiekvienu teiginiu pažymèkite skaičiu, kurio reikšme labiausiai atitinka Jüsu požiūrị. Skaiči reikšmes: 1 -visiškai neaktualu; 2 -labiau neaktualu, nei aktualu; 3-nei neaktualu, nei aktualu; 4-labiau aktualu, nei neaktualu; 5-labai aktualu; 6-nežinau.

\section{Nežinau}

1. Bibliotekų vidinės aplinkos tyrinëjimus (vidinių sąlygų ir veiksnių, kliudančių arba skatinančių bibliotekos vystymąsi, tyrinejjimai).

2. Biblioteku išorinès aplinkos tyrinëjimus (išorinių sąlygų ir veiksnių, darančių įtaką bibliotekos veiklai, sukeliančių poreikị keistis tyrinéjimai).

3. Dokumentu fondo vystymo tyrinèjimus (struktūros, turinio, dokumentų rūšių, dokumentų paskirstymo sistemose, naujinimo ir panaudojimo, bibliotekoje esančių ir jai prieinamų informacijos šaltinių reikšmingumo bei vietos fondo struktūroje ir pan. tyrinèjimai). 
4. Bibliotekų vartotojų ir jų poreikių raidos tyrinëjimus (vartotojų lūkesčių, jų požiūrio ì bibliotekos paslaugas, produktus, personalą, techninị aprūpinimą, informacijos ieškos ir informacinio aptarnavimo sistemas, teikiamų paslaugų kokybę ir pan. tyrinèjimai).

5. Skaitymo vaidmens ir funkcijų tyrinëjimus (skaitymo motyvacijos, skaitymo ir kitų informacijos šaltinių naudojimo ir pan. tyrinèjimai).

6. Profesijos kaitos (modifikacijos) tyrinëjimus.

7. Bibliotekų techninio aprūpinimo, materialinių išteklių ir jų atitikties visuomenès poreikiams tyrinëjimus.

8. Bibliotekų veiklos tendenciju pasaulyje (šalyje, regione) tyrinèjimus.

9. Naujų, konkurencingų bibliotekų veiklos rūšiu jų technologijų ir metodikų tyrinëjimus.

10. Naujų bibliotekinių veiklos produktu, užtikrinančių dokumentų ir informacijos prieinamumą, tyrinejjimus.

11. Naujų bibliotekinių veiklos produktų, užtikrinančių bibliotekų konkurencingumą, tyrinëjimus.

Kita (prašom pažymèti vertinimus, o tekstą įrašyti toliau esančiame langelyje)

Kita (prašom įrašyti)

5. Ar Jūsų bibliotekos nuostatuose yra numatyta mokslinių tyrimų vykdymo funkcija?

$\square \quad$ Taip

$\square \mathrm{Ne}$

6. Ar Jūsų bibliotekoje atlikti tiriamosios veiklos (taikomujų mokslinių tyrimų, rinkos tyrimų, veiklos ar atskirų veiklos sričių analizès) rezultatai paskatino joje įdiegti naujoves?

Pasirinkite visus, Jüsų nuomone, Jüsų bibliotekai tinkamus variantus arba įrašykite savo pastabas.

$\square \quad$ Sukūrème naujas paslaugas

$\square$ Patobulinome teikiamas paslaugas

$\square$ Sukūrème (įdiegème) naujus technologinius procesus

$\square$ Patobulinome technologinius procesus 
$\square$ Padarème naujus ir (arba) patobulinome esančius organizacinius sprendimus

$\square \quad$ Naujovių neįdiegėme (pereikite prie 8 klausimo)

Kitas variantas (prašom įrašyti)

\section{Prašom išvardyti 1-2 pačias reikšmingiausias naujoves, kurias paska- tino įdiegti Jūsų bibliotekoje atliktos tiriamosios veiklos rezultatai.}

Prašom įrašyti.

\section{Ar, Jūsų nuomone, Jūsų savivaldybès viešojoje bibliotekoje turètų}

\section{būti atliekami taikomieji moksliniai tyrimai*?}

* Moksliniai tyrimai čia suprantami kaip bibliotekos tiriamosios veiklos kryptis, kai vykdomi taikomojo pobūdžio moksliniai darbai, sistemingai ir organizuotai nagrinejjantys tikrovės objektus, naudojant mokslo priemones ir metodus.

Pasirinkite atsakymo varianta; jei pasirinkote "Ne“, toliau esančiame langelyje parašykite trumpa komentara ir pereikite prie 10 klausimo, jei pasirinkote atsakyma "Neturiu nuomones", pereikite prie 10 klausimo.

$\square \quad$ Taip

$\square \quad \mathrm{Ne}$ (toliau esančiame langelyje pakomentuokite ir pereikite prie 10 klausimo)

$\square \quad$ Neturiu nuomonès (pereikite prie 10 klausimo)

Jei i 8 klausima atsakète "Ne“, šiame langelyje prašom pakomentuoti ir pereiti prie 10 klausimo

9. Jei taikomieji moksliniai tyrimai Jüsų bibliotekoje turètų büti atliekami, kaip, Jüsu nuomone, tai turètu vykti?

Ivertinkite toliau pateiktus teiginius pagal 5 balu skalę. Balu reikšmes: 1 - visiskai nepritariu; 2 - labiau nepritariu, nei pritariu; 3 - nei pritariu, nei nepritariu; 4 -labiau pritariu, nei nepritariu; 5 - visiškai pritariu; 6-nežinau.

1. Biblioteka mokslinius tyrimus turètų atlikti savarankiškai, kartu užtikrindama, kad jos personalas turètu reikiamas kompetencijas šiai veiklai.

2. Biblioteka mokslinius tyrimus turètų atlikti bendradarbiaudama su aukštosiomis mokyklomis. 
3. Biblioteka mokslinius tyrimus turètu atlikti bendradarbiaudama su Lietuvos nacionalinès bibliotekos specialistais.

4. Biblioteka mokslinius tyrimus turètu atlikti bendradarbiaudama su apskrities viešosios bibliotekos specialistais.

5. Biblioteka turètų tik dalyvauti atliekant mokslinius tyrimus (surinkti reikiamus duomenis, organizuoti apklausas, atlikti kitus techninio pobūdžio darbus).

6. Moksliniai tyrimai turètų būti atliekami bibliotekos bazèje, tačiau organizuoti ir atlikti juos turi institucijos, kurių personalas turi būtinas šiai veiklai kompetencijas.

\section{Ar, Jūsų nuomone, Jūsų savivaldybès viešojoje bibliotekoje turètų būti atliekami rinkos tyrimai?}

Pasirinkite atsakymo varianta; jei pasirinkote "Ne“, toliau esančiame langelyje parašykite trumpa komentara. Jei pasirinkote atsakyma "Neturiu nuomones", pereikite prie 12 klausimo.

\section{Taip}

$\square \mathrm{Ne}$ (toliau esančiame langelyje pakomentuokite ir pereikite prie 12 klausimo)

$\square \quad$ Neturiu nuomonès (pereikite prie 12 klausimo)

Jei i 10 klausima atsakète "Ne“, siame langelyje pakomentuokite ir pereikite prie 12 klausimo.

\section{Jei rinkos tyrimai Jūsų bibliotekoje turètų būti atliekami, kaip, Jūsų nuomone, tai turètų vykti?}

Ivertinkite toliau pateiktus teiginius pagal 5 balu skalę. Balu reikšmes: 1 - visiškai nepritariu; 2 - labiau nepritariu, nei pritariu; 3 - nei pritariu, nei nepritariu; 4 -labiau pritariu, nei nepritariu; 5 - visiškai pritariu; 6 - nežinau.

1. Biblioteka rinkos tyrimus turètų organizuoti ir atlikti savarankiškai, kartu užtikrindama, kad jos personalas turètų tam reikiamas kompetencijas.

2. Biblioteka rinkos tyrimus turètu atlikti savarankiškai, jei šiuo klausimu jai būtų užtikrinta informacinè, metodinè ir konsultacinè pagalba. 
3. Biblioteka rinkos tyrimus turètų užsakyti specializuotoms institucijoms (rinkos tyrimų bendrovèms, agentūroms ir pan.).

4. Biblioteka rinkos tyrimus turètų atlikti bendradarbiaudama su Lietuvos nacionaline biblioteka.

5. Biblioteka rinkos tyrimus turètų atlikti bendradarbiaudama su apskrities viešąja biblioteka.

6. Biblioteka gali tik dalyvauti atliekant rinkos tyrimus (surinkti ir teikti duomenis, organizuoti apklausas, atlikti kitus organizacinio pobūdžio darbus).

7. Rinkos tyrimai gali būti atliekami bibliotekos bazèje, tačiau organizuoti ir vykdyti juos turi kitų institucijų darbuotojai, turintys būtinas šiai veiklai kompetencijas.

Kita (pažymèkite vertinimus, o teksta įrašykite toliau esančiame langelyje) Kita (prašom įrašyti)

\section{Ar, Jūsų nuomone, Jūsų bibliotekoje turètų būti atliekami infor- maciniai analitiniai* darbai?}

* Informaciniai analitiniai darbai - tai analitinès atskiro laikotarpio (pavyzdžiui, metu), atskirų struktūrinių padalinių, vienos ar kelių veiklos sričių, veiklos turinio ir pan. ataskaitos, apžvalgos, analizès, vertinimai ir t. t.

Jei pasirinkote atsakyma "Ne“, toliau esančiame langelyje pakomentuokite ir pereikite prie 14 klausimo; jei pasirinkote atsakyma „Neturiu nuomones", pereikite prie 14 klausimo.

$\square \quad$ Taip

$\square \quad \mathrm{Ne}$ (toliau esančiame langelyje pakomentuokite ir pereikite prie 14 klausimo)

$\square \quad$ Neturiu nuomonès (pereikite prie 14 klausimo)

Jei i 12 klausima atsakète „Ne“, siame langelyje pakomentuokite ir pereikite prie 14 klausimo.

\section{Jei informaciniai analitiniai darbai Jūsų bibliotekoje turètų būti atliekami, kaip, Jūsų nuomone, tai turètų vykti?}

Ivertinkite toliau pateiktus teiginius pagal 5 balu skalę. Skaičiu reikšmes: 1 - visiškai nepritariu; 2 -labiau nepritariu, nei pritariu; 3 -nei pritariu, nei nepritariu; 4-labiau pritariu, nei nepritariu; 5-visiškai pritariu; 6-nežinau. 
1. Biblioteka turètų savarankiškai analizuoti savo veiklą, kartu užtikrindama, kad jos personalas turètų šiai veiklai būtinas kompetencijas.

2. Biblioteka turètų savarankiškai organizuoti ir atlikti SVB, atskirų jos veiklos sričiu analizę ir vertinimą, tačiau jai šiais klausimais turètų būti teikiama informacinè, konsultacinè ir metodinè pagalba.

3. Biblioteka turi teikti reikiamus duomenis veiklos analizei, tačiau analizuoti ir vertinti juos turètų metodikos centrų specialistai.

Kita (prašom pažymèti vertinimus, o teksta ịrašyti toliau esančiame langelyje) Kita (prašom įrašyti)

14. Kam iš Jūsų bibliotekos darbuotojų (kuriai pareigybei, pareigybẻms) yra pavesta parengti SVB sistemos metų veiklos ataskaitą, išanalizuoti ir apibendrinti metų veiklos rezultatus?

Prašom ịrašyti pareigybiu pavadinimus; jei šis darbas pavestas darbo grupei, parašykite „Darbo grupei“ ir nurodykite grupes vadovo pareigas.

\section{Prašom įvertinti pateiktus teiginius apie pastaraisiais metais Jūsų bibliotekoje parengtas SVB sistemos metų veiklos ataskaitas.}

Vertinkite pagal 5 balu skalę, kur 1 - visiškai nepritariu; 2 - labiau nepritariu, nei pritariu; 3-nei pritariu, nei nepritariu; 4-labiau pritariu, nei nepritariu; 5-visiškai pritariu; 6-nežinau.

\section{Nežinau}

1. Metų veiklos ataskaita yra labai svarbus dokumentas SVB sistemos veiklai.

2. Metu veiklos ataskaita bibliotekoje yra rengiama labai atsakingai, laikantis visų šiam dokumentui privalomų reikalavimų.

3. Metų veiklos ataskaita bibliotekoje yra rengiama formaliai ir tik todèl, kad to reikalaujama ,iš aukščiau“.

4. Metu veiklos ataskaitos duomenys visuomet yra naudojami modeliuojant bibliotekos vystymo strategiją.

5. Metu veiklos ataskaitos rezultatai visuomet naudojami aiškinantis sistemos veiklos pasiekimus, trūkumus, spręstinas problemas. 
6. Metų veiklos ataskaita yra labai svarbus dokumentas, kai reikia pagrịsti finansavimo poreikị savivaldos struktūrose.

7. Bibliotekos darbuotojams visiškai pakanka žinių ir kompetencijų metų veiklos ataskaitai tinkamai parengti.

8. Bibliotekos darbuotojams visiškai pakanka laiko, kuris skiriamas metu veiklos ataskaitai tinkamai parengti.

Kita (prašom pažymèti vertinimus, o tekstą įrašyti žemiau esančiame langelyje) Kita (prašom įrašyti)

\section{Prašom labai įdèmiai perskaityti visus toliau išvardytus teiginius.}

Pasirinkite ir pažymèkite 1-3 teiginius, labiausiai atitinkančius Jūsų vertinimus, arba ịrašykite savo nuomonę.

$\square$ Šiuo metu naudojama metų veiklos ataskaitos struktūra, jos rengimo metodika visiškai tinkama SVB sistemos veiklos analizei ir tokia pat turètų išlikti ir ateityje.

$\square$ Metų veiklos ataskaitos struktūra, jos rengimo metodika yra tinkama SVB sistemos veiklos analizei, o aktualius pakeitimus ir patobulinimus kiekviena SVB pagal savo poreikius gali padaryti savarankiškai.

$\square$ Metų veiklos ataskaitos struktūra, jos rengimo metodika yra tinkama SVB sistemos veiklos analizei, tačiau būtina ją nuolat peržiūrèti ir centralizuotai parengti keitimus ir patobulinimus.

$\square$ Būtina peržiūrèti šiuo metu rengiamos SVB sistemos metų veiklos ataskaitos formą ir turinį ir padaryti esminius pakeitimus.

$\square$ Metų veiklos ataskaita ir metų veiklos analizė yra visiškai skirtingi dokumentai ir jie turi būti rengiami pagal skirtingas metodikas.

$\square$ SVB metų veiklos ataskaitos modeliai turi būti parengiami centralizuotai, laikantis bendrų visam SVB sektoriui reikalavimų.

$\square$ Kiekviena SVB turètų pasirengti individualų savo sistemos veiklos ataskaitos modeli, prisitaikydama prie jos savininko nustatytos tvarkos.

Kitas variantas (prašom įrašyti) 


\section{Ar kiekvienais metais Jūsų bibliotekoje yra rengiama daugiau negu viena SVB sistemos metų veiklos ataskaita?}

Pasirinkite viena Jüsu situacija labiausiai atitinkantị atsakyma; jei tokio nerasite, parasykite savo varianta.

$\square$ Taip, savivaldybei rengiama dar viena atskira SVB metu veiklos ataskaita pagal savivaldybės reikalavimus (rekomendacijas).

$\square \mathrm{Ne}$, tačiau savivaldybei teikiama radikaliai sutrumpinta ir pakoreguota pagal LNB rekomendacijas parengta SVB metų veiklos ataskaita.

$\square \mathrm{Ne}$, savivaldybei teikiama šiek tiek pakoreguota pagal LNB rekomendacijas parengta SVB metu veiklos ataskaita.

$\square \mathrm{Ne}$, savivaldybei teikiama pagal LNB rekomendacijas parengtos metu veiklos ataskaitos kopija.

$\square \quad \mathrm{Ne}$, savivaldybès institucijoms atsiskaitoma parengiant žodinị pranešimą pagal LNB rekomendacijas parengtos ataskaitos pagrindu.

$\square$ Savivaldybès institucijoms atsiskaitoma pateikiant atskirus duomenis apie SVB metų veiklos rezultatus taip, kaip šių duomenų pareikalauja savivaldos institucijos.

Kitas variantas (prašom įrašyti)

\section{Prašom įvertinti, ar toliau išvardytos priežastys yra reikšmingos kliūtys organizuoti ir vykdyti tiriamają veiklą SVB sistemose.}

Ties kiekvienu teiginiu pažymèkite skaičius, kuriu reikšmès labiausiai atitinka Jüsu vertinimus. Skaičiu reikšmes: 1 - visiškai nereikšminga; 2 - labiau nereikšminga, nei reikšminga; 3 - nei reikšminga, nei nereikšminga; 4 - labiau reikšminga, nei nereikšminga; 5 - labai reikšminga; 6 - nežinau.

\section{$\begin{array}{llllll}1 & 2 & 3 & 4 & 5 & \text { Nežinau }\end{array}$}

1. Bibliotekos vadovams trūksta teorinių žinių tiriamosios veiklos organizavimo ir vykdymo klausimais.

2. Bibliotekos vadovams stinga bazinių gebëjimų ir igūdžių tiriamosios veiklos organizavimo ir vykdymo klausimais.

3. Nepakanka informacijos ir žinių pasirenkant aktualias tyrinëjimų sritis SVB sistemoje. 
4. Nepakanka informacijos ir žinių apie viešųjų bibliotekų sektoriuje vykdomus tyrinëjimus.

5. Nepakanka informacijos ir žinių apie visame bibliotekų sektoriuje vykdomus tyrinëjimus.

6. SVB personalui nepakanka tiriamosios veiklos kompetencijų.

7. SVB personalui nepakanka vidinès motyvacijos tiriamajai veiklai.

8. Didelis SVB darbuotojų darbo krūvis kitose srityse trukdo tinkamai organizuoti ir atlikti tiriamąją veiklą SVB sistemoje.

9. Tiriamoji veikla nèra reikšminga veiklos sritis mūsų SVB.

10. Sunku įrodyti tiriamosios veiklos reikalingumą bibliotekos savininkui ir gauti finansavimą šiai veiklai.

11. Trūksta kokybiškų metodinių priemonių tiriamajai veiklai organizuoti ir vykdyti.

Kita (prašom pažymèti vertinimus, o tekstą įrašyti toliau esančiame langelyje) Kita (prašom įrašyti)

\section{Ar manote, kad Jums asmeniškai būtų naudinga sustiprinti toliau išvardytus tiriamosios veiklos gebèjimus?}

Ivertinkite teiginius pagal 5 balu skalę. Skaičiu reikšmes: 1 - visiškai nenaudinga; 2 - labiau nenaudinga, nei naudinga; 3 - nei naudinga, nei nenaudinga; 4 - labiau naudinga, nei nenaudinga; 5 - labai naudinga; 6 - nežinau.

$\begin{array}{llllll}1 & 2 & 3 & 4 & 5 & \text { Nežinau }\end{array}$

1. Tiriamosios veiklos organizavimas

2. Tiriamosios veiklos planavimas

3. Tiriamosios veiklos koordinavimas

4. Adekvačių tiriamosios veiklos metodų parinkimas ir tyrimo metodikosparengimas

5. Surinktų duomenų apdorojimas, interpretavimas ir vertinimas

6. Tiriamosios veiklos rezultatus apibendrinimo (ataskaitos ar kitokios medžiagos) parengimas

7. Tiriamosios veiklos rezultatų sklaidos organizavimas

Kita (pažymèkite vertinimus, o tekstą įrašykite toliau esančiame langelyje) Kita (prašom įrašyti) 
20. Kokius tiriamosios veiklos gebèjimus, Jūsų nuomone, būtų tikslingiausia stiprinti Jūsų bibliotekos personalui?

Ties kiekvienu teiginiu pažymèkite skaičìu, kurio reikšmè labiausiai atitinka Jüsu požiürį. Skaičiu reikšmes: 1 - visiškai nenaudinga; 2 - labiau nenaudinga, nei naudinga; 3 -nei naudinga, nei nenaudinga; 4 - labiau naudinga, nei nenaudinga; 5 - labai naudinga; $6-$ nežinau.

\section{Nežinau}

1. Tiriamosios veiklos organizavimas

2. Tiriamosios veiklos planavimas

3. Tiriamosios veiklos koordinavimas

4. Adekvačiu tiriamosios veiklos metodų parinkimas ir metodikos parengimas

5. Surinktų duomenų apdorojimas, interpretavimas ir vertinimas

6. Tiriamosios veiklos rezultatu apibendrinimo (ataskaitos ar kitokios medžiagos) parengimas

7. Tiriamosios veiklos rezultatų sklaidos organizavimas

Kita (pažymékite vertinimus, o teksta ịrašykite toliau esančiame langelyje) Kita (prašom įrašyti)

21. Ar per pastaruosius dvejus metus Jūs asmeniškai organizavote, savarankiškai atlikote taikomaji mokslinị tyrimą, rinkos tyrimą ar dalyvavote tokius tyrimus atliekant?

Pasirinkite visus Jums tinkamus variantus arba, jei tinkamo nesurasite, įrašykite savo varianta.

$\square$ Organizavau mokslinị tyrimą

$\square$ Organizavau rinkos tyrimą

$\square$ Savarankiškai atlikau mokslinị tyrimą

$\square$ Savarankiškai atlikau rinkos tyrimą

$\square$ Dalyvavau atliekant mokslinị tyrimą (pereikite prie 23 klausimo)

$\square$ Dalyvavau atliekant rinkos tyrimą (pereikite prie 23 klausimo)

$\square \quad \mathrm{Ne}$ (pereikite prie 23 klausimo) 
22. Jei per pastaruosius dvejus metus savarankiškai atlikote mokslini arba rinkos tyrimą, prašom nurodyti jo pavadinima, rezultatų publikavimo formą ir publikavimo šaltinị, jei rezultatai buvo publikuoti.

\title{
23. Jūsų mokslo laipsnis, išsimokslinimas:
}

\author{
$\square$ Aukštasis, igytas iki 1995 metu \\ $\square$ Magistras \\ $\square$ Bakalauras \\ $\square$ Profesinis bakalauras \\ $\square$ Aukštesnysis \\ $\square$ Specialusis vidurinis \\ $\square \quad$ Kitas (prašom įrašyti)
}

\section{Studijų kryptis:}

Pasirinkite Jums tinkantị varianta. Pasirinkę varianta "Kita", studiju kryptì żrašykite toliau esančiame langelyje.

$\square$ Bibliotekininkystè, informacijos ir komunikacijos krypčių grupé

$\square$ Kita (pvz., švietimas ir ugdymas, filologija, kultūros studijos, sociologija, vadyba ir t. t.)

Jei pasirinkote atsakyma „Kita“, prašom i̇rašyti studiju kryptį.

\section{Jūsų darbo stažas einant šias pareigas:}
$\square \quad$ Pirmi darbo metai
$\square \quad 1-5$ metai
ㅇ-10 metu
ㅁ 11-15 metu
ㅁ 16-20 metu
21-30 metu
$\square \quad 31$ ir daugiau metu 
26. Jūsų amžius:
$\square \quad$ Iki 30 metu
31-40 metu
$\square \quad 41-50$ metu
51-60 metu
$\square \quad 61$ ir daugiau

27. Prašom nurodyti apskritị, kurios teritorijoje yra Jūsų biblioteka:

Duomenys reikalingi atsakymams paskirstyti.
$\square$ Alytaus
$\square$ Kauno
$\square$ Klaipédos
$\square \quad$ Marijampolès
$\square \quad$ Panevėžio
$\square$ Telšiu
$\square$ Tauragès
$\square$ Šiaulių
$\square$ Utenos
$\square \quad$ Vilniaus 


\section{MOKSLO TIRIAMOJI VEIKLA SAVIVALDYBIŲ VIEŠOSIOSE BIBLIOTEKOSE}

\section{Anketa bibliotekų darbuotojams}

Gerbiami kolegos,

Lietuvos apskričiu viešosios bibliotekos, bendradarbiaudamos su Lietuvos nacionaline biblioteka, atlieka tyrimą „,Savivaldybių viešųjų biblioteku mokslo (tiriamoji) veikla 2010-2015 metais“. Šio tyrimo tikslas išsiaiškinti, kokiu būdu savivaldybių viešosios bibliotekos dalyvauja (ar galètų dalyvauti) kuriant ir panaudojant bibliotekininkystès ir informacijos mokslo žinias. Tyrimo rezultatai padès sužinoti, kaip šios žinios galètų būti efektyviau panaudojamos viešujų bibliotekų sektoriuje, aiškiau apibrěžti pačių SVB vaidmenị jas kuriant, išsiaiškinti su tiriamosios veiklos* organizavimu savivaldybių viešosiose bibliotekose susijusias problemas.

I anketos klausimus prašome atsakyti tuos SVB darbuotojus, kurie dalyvauja (ar pagal einamas pareigas galètu dalyvauti) bibliotekos vykdomoje tiriamojoje veikloje. Visuose duomenu rinkimo, jų apdorojimo ir suvestinès informacijos rengimo bei skelbimo etapuose bus užtikrintas gautų duomenų konfidencialumas, šalinama bet kokia informacija, kurios pagrindu duomenis pateikęs asmuo galètų būti tiesiogiai ar netiesiogiai identifikuotas.

\section{Būsime nuoširdžiai dèkingi, jei ịdèmiai ịsiskaitysite ir atvirai atsakysite ị pateiktus klausimus.}

\footnotetext{
* Tiriamoji veikla čia suprantama kaip sistemingai atliekamas kürybinis pažinimo darbas, apimantis bibliotekose atliekamus mokslinius tyrimus, rinkos tyrimus ir (arba) tyrimus, reikalingus vadybiniams sprendimams parengti, ịvairovę analitiniu darbu, kuriais siekiama spręsti praktinius uždavinius (metines bibliotekos veiklos ataskaitas, bibliotekos veiklos ar atskiru jos veiklos sričiu analize ir prognozes, galimybiu vertinimus ir t. t.), taip pat veiklas, skleidžiant informacija apie tiriamuju darbu rezultatus bei integruojant šiuos rezultatus ị biblioteku praktiką.
} 
1. Ar, Jūsų nuomone, tiriamosios veiklos kompetencija yra neatsiejama Jūsų profesinès kompetencijos dalis?

Pažymékite viena Jüsu nuomonę labiausiai atitinkantį atsakymo variantą.

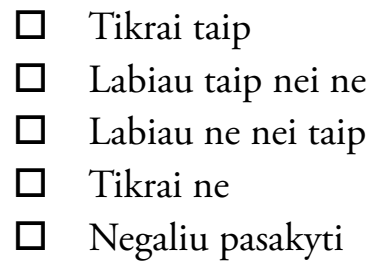

2. Ar ịpareigojimai vykdyti (organizuoti, koordinuoti) tiriamają veiklą arba dalyvauti joje yra ịrašyti Jūsų pareiginiuose nuostatuose?

Pasirinkite viena Jums tinkama varianta.
$\square$ Taip
$\square \mathrm{Ne}$
$\square \quad$ Nežinau

3. Prašom pažymèti, kaip dažnai per pastaruosius dvejus metus Jums teko atlikti toliau išvardytus darbus:

Pasirinkite Jums tinkančius atsakymus ir ties jais pažymeikite skaičiu, kuris labiausiai atitinka Jüsu situacija; skaičiu reikšmès: 1 - kelis kartus per mennesij; 2 - ne dažniau nei karta per menesi;; 3 - ne dažniau nei karta per pusmeț; 4-karta per metus; 5-niekada neteko; 6 - negaliu pasakyti.

12345 Negaliu pasakyti

1. Organizuoti taikomuosius mokslinius, rinkos tyrimus ir vadovauti juos vykdančios grupès darbui.

2. Atlikti taikomuosius mokslinius, rinkos tyrimus (rengti tyrimo dokumentus, atlikti tyrimo veiksmus, rengti tyrimo ataskaitas ir jų publikacijas).

3. Dalyvauti atliekant taikomuosius mokslinius, rinkos tyrimus (dalyvauti darbo grupèse arba savarankiškai atlikti už tiriamąją veiklą atsakingu asmenų pavedamus darbus). 
4. Rengti atskirų bibliotekos veiklos sričių (arba filialo veiklos) analizes ir vertinimus (surinkti ir analizuoti duomenis, rengti išvadas, prognozes, rekomendacijas).

5. Rinkti duomenis apie kitose bibliotekose, mokslo institucijose atliktu tyrimu rezultatus; juos apibendrinti ir (ar) rengti ju pritaikymo SVB rekomendacijas.

6. Konsultuoti tiriamojo darbo organizavimo ir igyvendinimo klausimais SVB darbuotojus.

7. Organizuoti mokslinius-praktinius seminarus, konferencijas, kitus renginius savivaldybès (ir (arba) regioniniu, nacionaliniu, tarptautiniu) lygmeniu.

8. Prižiūrèti (pildyti arba dalyvauti prižiūrint (pildant) elektroninių tinklinių priemonių (tinklaraščio, tinklalapio, e. svetainès ir pan.) turinị tiriamojo darbo klausimais.

9. Skaityti bibliotekininkystès ir su šia sritimi susijusių mokslų (informacijos ir komunikacijos krypčiu) mokslines publikacijas.

10. Skaityti kitų mokslo krypčių mokslines publikacijas.

\section{Prašom nurodyti išsamiau, kuriuos darbus, susijusius su tiriamaja veikla, per pastaruosius dvejus metus Jums teko atlikti?}

Pasirinkite Jums tinkančius atsakymus. Ties kiekvienu iš pasirinktu atsakymu pažymèkite skaičiu, kuris atitinka Jüsu atliekamų darbu dažnuma. Skaičiu reikšmès: 1 - kelis kartus per menesį; 2 - ne dažniau nei karta per mènesį; 3 - ne dažniau nei karta per pusę metu; 4-karta per metus; 5 - niekada neteko; 6-negaliu pasakyti.

\section{Negaliu pasakyti}

1. Rengti klausimynus, interviu planus ir pan.

2. Organizuoti tiriamųjų apklausas (išdalyti ir surinkti klausimynus, sukviesti tiriamuju grupes ir organizuoti darbą šiose grupèse).

3. Apklausti tiriamuosius žodžiu pagal sudarytus apklausų (interviu) planus

4. Apdoroti ir apibendrinti apklausos (anketavimo, interviu) duomenis.

5. Rengti tyrimo (-u) ataskaitas (apibendrinti duomenis, parinkti grafiku ir paveikslų dizainą, rašyti ataskaitos tekstus ir t. t.).

6. Rengti pranešimus, straipsnius, kitas tiriamųjų darbu publikacijas ir organizuoti jų sklaidą (profesinëje bendruomenejje, spaudoje, interneto erdveje ir pan.). 
7. Surinkti, analizuoti ir apibendrinti statistinius duomenis metinei SVB veiklos ataskaitai.

8. Rengti bendrą bibliotekos metų veiklos ataskaitą: sutvarkyti ir analizuoti darbuotojų pateiktus statistinius duomenis, rašyti apibendrinančius tekstus.

9. Rengti atskiros SVB veiklos srities (fondo sudarymo, vartotoju aptarnavimo, atskirų SVB struktūrinių padalinių ir pan.) statistinių duomenų analizę ir tekstą metinei veiklos ataskaitai.

10. Rengti vienos ar kelių bibliotekos veiklos sričių analizę, prognozuoti jos (ju) vystymo perspektyvas, teikti šio pobūdžio rekomendacijas bibliotekos vadovui (-ams).

\section{Ar tiriamoji veikla yra Jūsų pagrindinè veikla bibliotekoje?}

Vertinkite dabartine situacija ir pasirinkite viena iš pateikiamu variantu arba įrašykite savo versija.

$\square \quad$ Taip

$\square \quad$ Ne, tai yra man paskirtos papildomos pareigos

$\square$ Šios pareigos yra tik įrašytos mano pareiginiuose nuostatuose, konkrečių darbų atlikti neteko

$\square \quad$ Šios pareigos neįrašytos mano pareiginiuose nuostatuose, tačiau aš dažnai esu ịpareigojama (-as) tokius darbus atlikti

Kitas variantas (prašom įrašyti)

\section{Ar savivaldybès viešoji biblioteka, Jūsų nuomone, yra institucija, kuri turètų:}

Pažymèkite skaičiu, kuris atitinka Jüsu vertinima. Vertinimai: 1 - tikrai ne; 2 - labiau ne; 3-nei taip nei ne; 4-labiau taip; 5-tikrai taip; 6-nežinau.

1. Savarankiškai atlikti mokslinius tyrimus (savarankiškai pasirinkti tyrimu temas, rengti tyrimų dokumentus, atlikti tyrimų veiksmus, rengti tyrimų ataskaitas, organizuoti tyrimų rezultatų sklaida).

2. Savarankiškai atlikti rinkos tyrimus (savarankiškai pasirinkti tyrimų temas, rengti tyrimų dokumentus, atlikti tyrimu veiksmus, rengti bibliotekos raidos prognozes, rekomendacijas dèl veiklos tobulinimo ir jas igyvendinti). 
3. Planingai ir sistemingai atlikti informacinius analitinius darbus (rengti analitines veiklos ataskaitas, rinkti duomenis, juos analizuoti, vertinti, rengti rekomendacijas dèl veiklos pokyčių ir pan.).

7. Ar, Jūsų nuomone, tiriamoji veikla Jūsų bibliotekoje vertinama kaip intelektuali ir reikšminga bibliotekos ir visos SVB sistemos raidai veikla?

Pažymèkite viena Jüsu nuomonę atitinkantị variantą arba parašykite savo pastabas.

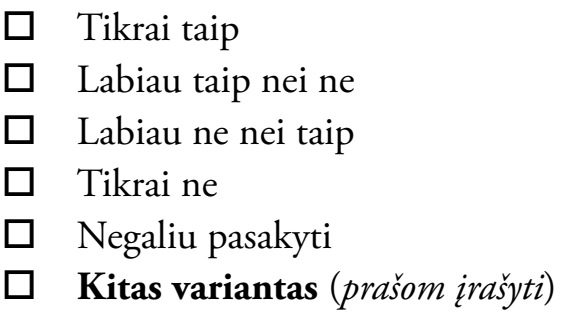

8. Kaip manote, ar Jūsų bibliotekoje atlikti tyrinèjimai (arba analitiniai informaciniai darbai) daro teigiamą įtaką SVB sistemos veiklos rezultatams?

Pasirinkite Jüsų nuomonę atitinkančius atsakymus arba parašykite savo pastabas.

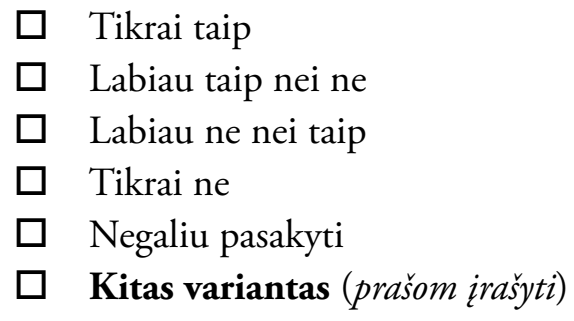

9. Ivvertinkite toliau pateiktus teiginius apie Jūsų bibliotekoje rengiamas metu veiklos ataskaitas.

Pažymèkite skaičius, kurie labiausiai atitinka Jüsu vertinima. Skaičiu reikšmès: 1 visiškai nepritariu; 2 - labiau nepritariu, nei pritariu; 3 - nei pritariu, nei nepritariu; 4 -labiau pritariu, nei nepritariu; 5 - visiškai pritariu; 6-nežinau. 
1. Metu veiklos ataskaita yra bibliotekos veiklai labai svarbus dokumentas.

2. Metų veiklos ataskaitos bibliotekoje rengiamos atsakingai, laikantis visu šiam dokumentui keliamų reikalavimų.

3. Metų veiklos ataskaitos bibliotekoje rengiamos formaliai ir tik todèl, kad to reikalaujama „iš aukščiau“.

4. Metų veiklos ataskaitos rezultatai visuomet naudojami numatant bibliotekos vystymo strategiją.

5. Metu veiklos ataskaitos rezultatai visuomet naudojami planuojant bibliotekos veiklą.

6. Metų veiklos ataskaitos rezultatai visuomet naudojami aiškinantis bibliotekos pasiekimus, trūkumus, spręstinas problemas.

7. Metų veiklos rezultatais yra grindžiamas bibliotekos finansavimo poreikis.

8. Bibliotekos darbuotojams visiškai pakanka kompetencijų metų veiklos ataskaitai tinkamai parengti.

9. Bibliotekos darbuotojams visuomet pakanka laiko metų veiklos ataskaitai tinkamai parengti.

\section{Ar Jums asmeniškai visuomet pakanka kompetencijų Jums pave- damiems tiriamiesiems darbams atlikti?}

Pasirinkite vieną labiausiai Jüsy nuomone atitinkantį varianta arba įrašykite savo pastabas.

$\square \quad$ Taip, visiškai pakanka

$\square$ Pakanka

$\square$ Dažniau pakanka, negu nepakanka

$\square$ Dažniau nepakanka, negu pakanka

$\square$ Visiškai nepakanka

$\square \quad$ Kitas variantas (prašom ịrašyti)

\section{Prašom pažymèti, kuriose iš toliau išvardytų tiriamosios veiklos sričių Jums dažniausiai pristinga žinių.}

Pasirinkite Jums tinkančius atsakymus ir ties jais pažymèkite skaičiu, kuris labiausiai atitinka Jüsu situacija; skaičiu reikšmès: 1 - visuomet pristinga žiniu; 2 - dažnai pristinga žiniu; 3 - retai pristinga žinių; 4 - labai retai pristinga žiniu; 5 - niekada nepristinga žiniu; 6 - šių darbų neatlieku.

12345 Šių darbų neatlieku 
1. Nustatant tyrinëjimų problemą, temą, jos aktualumą ir reikšmingumą

2. Nustatant tiriamojo (informacinio analitinio) darbo tikslus

3. Organizuojant tiriamąją veiklą bibliotekoje ir jos teritoriniuose padaliniuose

4. Organizuojant tiriamojo darbo grupes ir koordinuojant jų veiklą

5. Atrenkant tyrimui reikalingas publikacijas, analizuojant ir vertinant ju turinị

6. Numatant tiriamojo darbo uždavinius

7. Išsiaiškinant temos, problemos, veiklos srities ištyrimo lygi

8. Parenkant tyrinëjimo (informacinio analitinio darbo) metodiką: atsirenkant tyrimo metodus, pagrindžiant jų patikimumą

9. Pasirenkant tyrinëjimo (informacinio analitinio darbo) instrumentus: nustatant duomenų atrankos kriterijus, duomenų analizès metodus, rengiant anketas, interviu, stebejjimo ir pan. planus

10. Apdorojant duomenis: analizuojant, apibendrinant, kritiškai įvertinant ir išaiškinant gautus rezultatus

11. Aprašant gautus rezultatus, kuriant darbo rezultatu apibendrinimo tekstą (lingvistinių kompetencijų)

12. Formuluojant išvadas

13. Rengiant rekomendacijas

14. Pasirenkant darbo rezultatų apipavidalinimo priemones: paveikslų, diagramų, schemų, lentelių grafinius modelius, juos kuriant ir atvaizduojant

15. Pristatant rezultatus tikslinei grupei (darbuotojams, bibliotekos vadovams, savivaldybès institucijoms, profesinei bendruomenei ir pan.)

\section{Kokių žinių tiriamosios veiklos srityje Jūs asmeniškai norètumète igyti?}

Pasirinkite Jums tinkančius atsakymus ir ties jais pažymèkite skaičiu, kuris labiausiai atitinka Jüsu situaciją; skaičiu reikšmes: 1 - mažiausiai reikalingos žinios; 5 - labiausiai reikalingos žinios; 6 - negaliu pasakyti.

12345 Negaliu pasakyti 
1. Teorinių žinių apie mokslo tiriamą̧ą veiklą

2. Teorinių žinių apie informacinę analitinę veiklą

3. Mokslinių tyrimų metodologijos

4. Rinkos tyrimu metodologijos

5. Bibliotekos veiklos analizès metodikos

6. Statistinès analizès žinių ir igūdžių

7. Tyrinëjimu, informacinès analitinès veiklos rezultatų vertinimo ir aprašymo žinių ir igūdžiu

8. Tyrinejjimu, informacinès analitinès veiklos rezultatų pristatymo ir viešinimo žinių ir igūdžių

9. Tyrimų, analitinès veiklos SVB sistemoje organizavimo žinių ir igūdžių

\section{Prašom pažymèti, kokius statistinès analizès metodus naudojate savo darbe:}

Pasirinkite visus Jums tinkančius variantus arba įrašykite papildomai.

Aprašomosios statistikos

$\square$ Koreliacinès analizès

$\square \quad$ Faktorinès analizès

$\square$ Regresinès analizès

$\square \quad$ Nenaudoju né vieno iš šių metodų

$\square$ Negaliu pasakyti (neturiu žinių nè apie vieną iš šių metodu)

$\square \quad$ Kitas variantas (prašom įrašyti)

14. Kokia statistinių duomenų apdorojimo programine įranga (programiniais paketais), jų elektroninèmis skaičiuoklèmis ir pan. naudojatès savo darbe?

Pasirinkite Jums tinkančius variantus ir (arba) įrašykite kita Jüsų naudojama ìranga.

$\square$ SPSS (Statistical Package for the Social Sciences)

$\square$ Microsoft Office Excel

$\square \quad$ Kitas variantas (prašom įrašyti) 


\section{Kaip vertinate savo profesinio tobulèjimo galimybes tyrinèjamo- sios veiklos srityje?}

Pasirinkite vienq labiausiai atitinkantị Jüsu vertinima varianta arba ịrašykite savo pastabas.

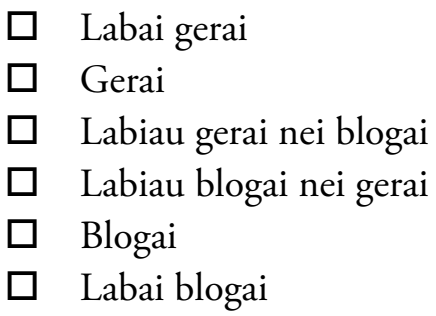

16. Kokios priemonès, Jūsų nuomone, padètų ịtvirtinti ir plètoti tiriamają veiklą Jūsų bibliotekoje (sistemoje)?

Pasirinkite tris, Jüsu nuomone, svarbiausias priemones; jei nesuradote Jüsu nuomone atitinkančio teiginio, parašykite savo variantą.

$\square$ Tinkamas specialistų parengimas tiriamajai veiklai

$\square$ Piniginis bibliotekos darbuotojų skatinimas už šios veiklos rezultatus

$\square$ Teigiamas bendradarbių požiūris ị šią veiklą bibliotekoje (sistemoje)

$\square$ Aktyvesnè mokslo žinių sklaida bibliotekinëje bendruomenëje (kongresų, mokslinių konferencijų, mokslinių praktinių seminarų ir pan. organizavimas savivaldybès regioniniu, nacionaliniu lygmeniu)

$\square$ Bibliotekos vadovų dèmesys ir pozityvus požiūris ị šią veiklą

$\square$ Ryšiu ir bendradarbiavimo su aukštosiomis mokyklomis stiprinimas

$\square \quad$ Ivairių lygių (savivaldos, regioninio, nacionalinio) bibliotekų bendradarbiavimo stiprinimas

$\square$ Efektyvi metodinè pagalba SVB organizuojant ir igyvendinant tiriamąją veiklą

$\square \quad$ Kitas variantas (prašom įrašyti) 


\section{Kas, Jūsų nuomone, labiausiai riboja Jūsų galimybes dalyvauti tiriamojoje veikloje?}

Pasirinkite tris, Jüsu nuomone, svarbiausias priežastis; jei nesuradote Jüsu nuomone atitinkančio teiginio, parašykite savo varianta

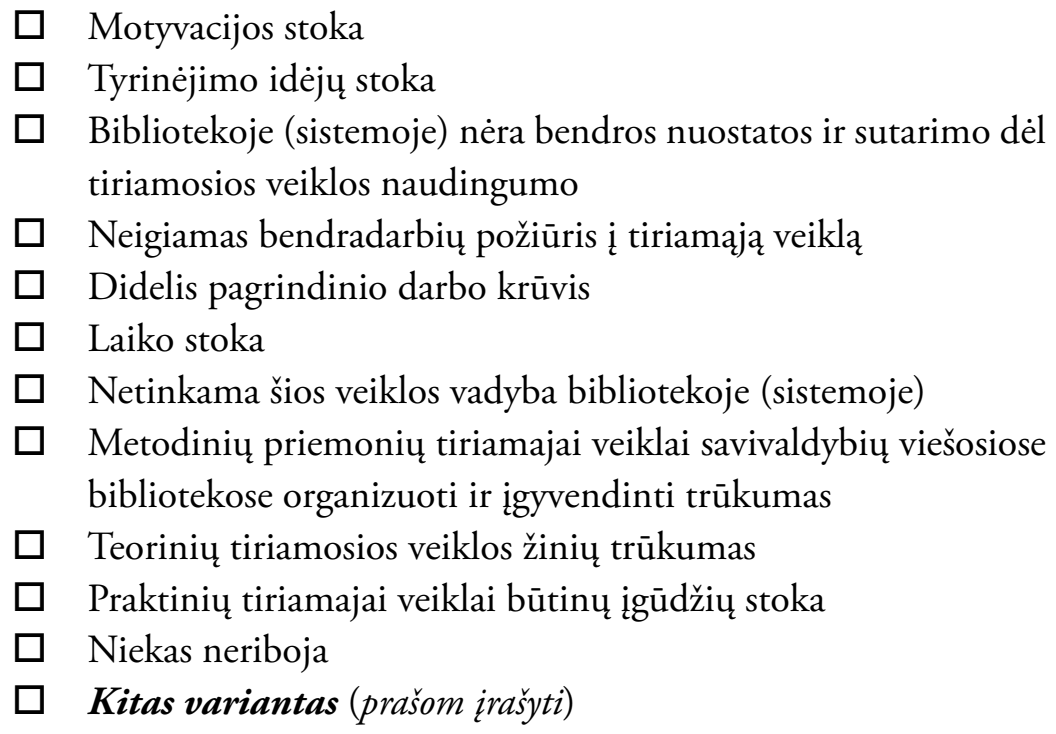

\section{Kurios mokymo formos Jums būtų tinkamiausios siekiant igyti papildomų žinių tiriamojo darbo srityje?}

Pasirinkite Jums tinkančius atsakymus ir ties jais pažymèkite skaičiu, kuris labiausiai atitinka Jüsu vertinimus; skaičiu reikšmess: 1 - visiškai netinkama; 2 - labiau netinkama, nei tinkama; 3 - nei tinkama, nei netinkama; 4-labiau tinkama, nei netinkama; 5 visiškai tinkama.

1. Paskaitos, seminarai

2. Stažuotès ir praktikumai mokymo bazèse

3. Specialistų konsultacijos

4. Dalykiniai žaidimai, diskusijos, imitaciniai žaidimai ir pan., formos, kai mokymo dalyviai savarankiškai ieško iškylančių problemų sprendimų

6. Mokymai naudojant kompiuterines programas (nuotolinis mokymas)

7. Savarankiškas darbas pačiai (-iam) pasirenkant mokymosi šaltinius

8. Savarankiškas darbas naudojantis nurodytais mokymo(si) šaltiniais 
Kitas variantas (prašom pažymèti vertinimus, o teiginị įrašyti toliau esanciame langelyje)

Kitas variantas (prašom įrašyti)

\section{Ar per pastaruosius dvejus metus Jūs asmeniškai:}

Pasirinkite visus Jums tinkančius variantus.

$\square$ Organizavote mokslinị tyrimą

$\square$ Organizavote rinkos tyrimą

$\square$ Savarankiškai atlikote mokslinị tyrimą

$\square$ Savarankiškai atlikote rinkos tyrimą

$\square$ Dalyvavote atliekant mokslinị tyrimą (pereikite prie 21 klausimo)

$\square \quad$ Dalyvavote atliekant rinkos tyrimą (pereikite prie 21 klausimo)

20. Jei per pastaruosius dvejus metus esate vadovavusi (-ęs) moksliniam ar rinkos tyrimui arba esate savarankiškai atlikusi (-ęs) mokslinị ar rinkos tyrimą, šiame langelyje nurodykite jo pavadinimą, rezultatụ publikavimo formą ir publikavimo šaltinị (jei tyrimo medžiaga publikuota)

\section{Jūsų pareigos bibliotekoje (šiuo metu).}

\section{Jūsų darbo vieta}

Jei dirbate viešojoje bibliotekoje, prašom nurodyti struktūrinio padalinio pavadinimą, jei teritoriniame struktüriniame padalinyje - dirbate miesto ar kaimo filiale.

\section{Mokslo laipsnis, išsimokslinimas:}

Pažymékite viena iš nurodytu variantų.

Aukštasis, igytas iki 1995 metų

$\square$ Magistro

$\square$ Bakalauro

$\square$ Profesinio bakalauro

$\square$ Aukštesnysis 
$\square \quad$ Specialusis vidurinis

$\square \quad$ Kitas variantas (prašom įrašyti)

\section{Studijų kryptis:}

Pažymèkite krypčiu grupę; jei pasirinkote „Kita“, krypties pavadinima ịrašykite toliau esančiame langelyje.

$\square$ Bibliotekininkystès, informacijos ir komunikacijos krypčių grupé

$\square \quad$ Kita (pvz., švietimas ir ugdymas, filologija, kultūros studijos, sociologija, vadyba ir t. t.)

Jei studijavote ne bibliotekininkystes, informacijos ir komunikacijos krypties programas, o kitas, prašom įrašyti studiju krypties pavadinima.

\section{Jūsų darbo stažas einant šias pareigas:}

$\square \quad$ Pirmi darbo metai

$\square \quad 1-5$ metai

$\square \quad 6-10$ metu

$\square \quad 11-15$ metu

16-20 metu

21-30 metu

$\square \quad 31$ ir daugiau metu

\section{Jūsų amžius:}

ㅁ Iki 20 metų

21-30 metu

$\square \quad 31-40$ metu

41-50 metu

51-60 metu

$\square \quad 61$ ir daugiau 
27. Prašom nurodyti apskritị, kurios teritorijoje yra Jūsų biblioteka: Duomenys reikalingi atsakymams paskirstyti.
$\square$ Alytaus
$\square$ Kauno
$\square \quad$ Klaipèdos
$\square$ Marijampolès
$\square \quad$ Panevėžio
$\square$ Telšiu
$\square$ Tauragès
$\square$ Šiaulių
$\square$ Utenos
$\square$ Vilniaus 